


\section{COLETA SELETIVA \\ E MINIMIZAÇÃO DE RESÍDUOS SÓLIDOS URBANOS: UMA ABORDAGEM INTEGRADORA}

Autora:

MARIA LUCIA BARCIOTTE

lore

Orientador:

Prof. Dr. ARISTIDES ALMEIDA ROCHA

Tese apresentada à Comissão Julgadora da Faculdade de Saúde Pública da USP como parte dos requisitos para a obtenção do Título de Doutora em Saúde Pública.

São Paulo / 1994

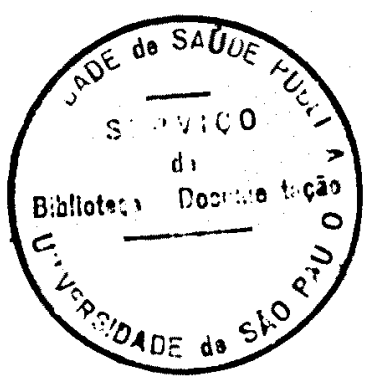


"Não há nenhum defeito naquele que procura a verdade baseado em suas próprias luzes; é mesmo um dever de cada um de nós".

"A verdade deve manifestar-se em nossos pensamentos. em nossas palavras. e em nossas açōes"

"Cada dia a natureza produz o suficiente para nossas carências. Se cada um tomasse o que the fosse necessário. não haveria pobreza no mundo e ninguém morreria de inanição".

(Gandhi) 
Eu dedico:

Aos meus filhos. Pedro e Bruna.

companheiros de jornada. fontes de luz e energia.

A minha mãe. meu pai e minha avó. pelas suas vidas. 
Eu agradeço:

Ao meu orientador. Prof. Dr. Aristides de Almeida Rocha, pelo seu saber, e, por sua presença me fazer lembrar que anjos da guarda existem.

Aos professores da Banca Examinadora, pelo tempo dispendido, e pelas valiosas contribuições.

Aos amigos Sabetai Calderoni e Solange

Alboreda, pela amizade, apoio e sugestões.

Aos amigos e colegas da CETESB que apoiaram o meu trabalho, e especialmente a Marcos de Almeida Alves Lima. Ana Maria Domingues Luz, Aracy Musolino Montineri, Júlia S. Alves. Edna Lopes Martoni e a Nivaldo Montingelli Jr. Aos colegas e amigos, Patricia R. Blauth, Fernando Luiz Prandini. Maria Aparecida Schoenacker. Henrique Gnani Braun. Gustavo Hallgren. Silvio Riccó, Liviu Schwarz, Vera Assis. Eunice Melhado de Lima, Maria Elisabeth Romano. Georgeta de Oliveira Gonçalves. Emílio Eigenheer. Regina Maria Manoel. José Amado. aos colegas membros da Comissão do Programa USP Recicla. e a todos que em ocasiōes profissionais ou sociais, constantemente reanimam a minha fé no trabalho. 


$$
\text { A colaboração e ao esforço de Andréia }
$$

Dias de Oliveira. Maria Eugênia Rodrigues, Francine Gramacho Sakata. Rita de Cássia Guimarães. Antonio Carlos Pajoli, Quitéria Braz Pereira. sem os quais teria sido impossível a realização deste trabalho.

A Familia Souza Cunha ( Diva, Rui, Lucas

e Samuell pela amizade e carinho.

A CAPES e à CETESB, pelo apoio à realização deste trabalho. 
INDICE

RESUMO. . . . . . . . . . . . . . . . . . . . . I

ABSTRACT $\ldots \ldots \ldots \ldots \ldots \ldots \ldots \ldots \ldots \ldots \ldots \ldots \ldots \ldots \ldots \ldots \ldots \ldots \ldots$

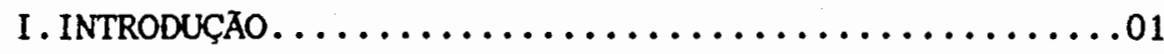

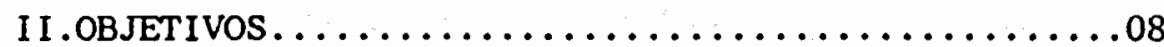

III.REVISAXO BIBLIOGRAFICA E SITUAC̣AO ATUAL

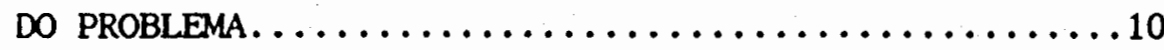

III.1.Resíduos sólidos urbanos: um novo ou

antigo problema $? \ldots \ldots \ldots \ldots \ldots \ldots \ldots \ldots \ldots \ldots$

III.2.Mas hoje, o que são os resíduos sólidos

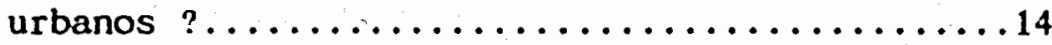

II I.3.Mas. como a população vê os residuos

sólidos urbanos $? \ldots \ldots \ldots \ldots \ldots \ldots \ldots \ldots \ldots \ldots$

III.4.Mas. os residuos sólidos urbanos, para

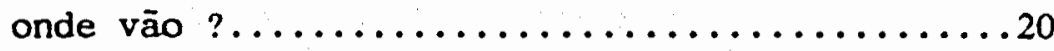

III.5.E como é a situação mundial dos

residuos $\quad \ldots \ldots \ldots \ldots \ldots \ldots \ldots \ldots \ldots \ldots \ldots \ldots \ldots \ldots \ldots$

III.6.Qual seria a solução $\ldots \ldots \ldots \ldots \ldots \ldots \ldots 25$

III.7.E a minimização dos resíduos sólidos

urbanos. é possível $\ldots \ldots \ldots \ldots \ldots \ldots \ldots \ldots 28$

III.8.E a coleta seletiva no Brasil ?........35

III.9.E então. como anda a reciclagem 


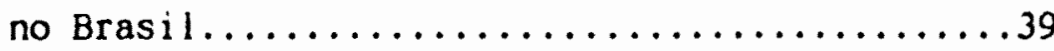

III.9.a. O Papel...................39

III.9.b. o vidro....................42

III.9.c. Os Plásticos................46

III.9.d. Os Metais......................

IV.METODOLOGIA. ................... 55

V.RESULTADOS E DISCUSSAO..............57

V.1. A experiência do municipio de

São Sebastião........................58

V.1.a. Metodologia de mobilização..........64

V.2. A experiência do município de

São José dos Campos.................66

V.2.a. Metodologia de mobilização.........72

V.3. A experiência do município de

Santos..........................

V.3.a. Metodologia de mobilizacão..........80

V.4. A experiência do município de

São Paulo..........................

V.4.a. Metodologia de mobilização...........88

V.5. A experiência da Favela Monte Azul.......91

V.6. A experiência da COOPAMARE...........94

V.7. Síntese das experiências............98

VI.CONCLUSAO.........................

VI I . RECOMENDAÇOES . . . . . . . . . . . . 120

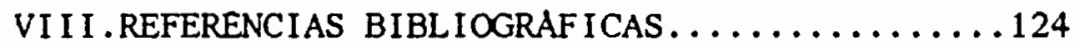


Este trabalho estudou alguns programas e atividades de coleta seletiva de materiais recicláveis presentes nos resíduos sólidos urbanos.Foram selecionados quatro programas municipais of iciais (São Sebastiāo, São José dos Campos, Santos e São Paulo) e dois trabalhos de organização espontânea (Favela Monte Azul e COOPAMARE/Cooperativa dos Catadores de Papel, Aparas e Materiais Recicláveis de São Paulol.

Levantaram-se as formas de implantação das diferentes experiências em estudo e de mobilização das suas respect ivas comunidades.

Constatou-se que, apesar das variaçōes encontradas nos diferentes casos, o envolvimento das comunidades foi significativo, fornecendo excelente oportunidade de percepção do espaço urbano e do exercício da cidadania, assim como da prática da máxima ambientalista "Pense globalmente, aja localmente".

Constatou-se ainda, que, pela complexidade do tema, é fundamental garantir a todas as pessoas envolvidas $e$ interessadas o acesso às informaçōes técnicas claras e precisas. assim como às práticas que motivem a participação de todos e ressaltem a importância do trabalho conjunto.

Concluiu-se que, apesar do bom resuitado dessas iniciativas. devem ser buscadas e enfatizadas açōes que promovam maior integraçào entre os vários segmentos da sociedade (catadores.populacão. empresários. políticos. artistas. meios de comunicacào. instituicōes de ensino. entidades religiosas. etcl. Deve-se priorizar práticas realmente integradoras e holisticas. capazes de promover a real prevençāo da poluição, através da minimizacão de resíduos, isto é. de sua diminuição. a partir da reducão na fonte, reutilização e reciclagem. 
This work consisted of a study of activities and programs of selective collection of recycled materials from urban solid waste.

The study is based on four official municipal programs (São Sebastião. São José dos Campos, Santos and São Paulol and two programs of spontaneous organization (Favela Monte Azul and COOPAMARE).

This work analyzed the ways of implementation of the referred different experiences and the mobilization of their respective communities.

It was verified that despite the observed variation in the different cases, the involvement of the communities was significant, providing an excellent opportunity of perception of the urban space and the practice of citizenship. as well as the environmenntalist maximm "Think globally, act locally".

It was also verified that due to the complexity of the subject. it is essential to ensure that all the people involved and interested have access to clear and precise technical information as well as to practices that stimulate participation and enhance the importance of collective work.

It was concluded that despite the good results of the referred initiatives. one must pursue and emphasize actions which encourage integration among different members of society (population, business people. politicians, artists. media. educational institutions. religious groups, etc). One must also emphasize holistic and integrated practices. in order to promote a real pevention of pollution. with waste minimization through reduction in the sources, reuse and recycling. 
I. INTRODUÇÃO 
O Brasil coleta anualmente mais de vinte mi hỏes de toneladas de resíduos sólidos urbanos e só a cidade de Säo Paulo contribui com cerca de 13000 ton/dia. ou seja,praticamente $20 \%$ deste valor. O total de resíduos sólidos urbanos gerados por um individuo. em regiões metropolitanas. é da ordem de $800 \mathrm{~g} / \mathrm{dia}(43)$ e tende a aumentar, pois está intimamente ligado ao modelo de consumo atual(17.19), baseado no desperdício de recursos naturais e no uso crescente de produtos descartáveis.

Os "historiadores", escreveu o crítico social Vance Packard em seu clássico de 1960 " The Waste Makers"(Estratégias do Desperdício)," podem referir-se à nossa época como " Era do Descartável"(19). Cita este autor ainda,una frase de um consultor de vendas americano que sintetiza o padrão de consumo vigente e/oụ almejado nestas últimas décadas: "A nossa economia enormemente produtiva... requer que nós façamos do consumo o nosso modo de vida. que nós convertamos a compra e o uso de mercadorias em rituais...Que nós busquemos a satisfação espiritual e do nosso ego no consumo... Nós precisamos de coisas consumidas. distraidas. gastas. substituidas e descartadas numa taxa cont inuamente crescente".

Trinta e quatro anos depois, sua descrição desta segunda metade do século XX. se mostra cada vez mais atual. Na realidade, hoje a população, principalmente aquela de regiōes urbanas e industrializadas, aceita como norma esta situacăo e mostra aspiração a um crescente consumo. 
Atualmente a grande maioria do municípios do Estado de são Paulo esta descartando os resíduos sólidos coletados (tabelas 6 e 7) de forma inadequada, pela simples disposição direta no solo. nos chamados lixões ou vazadouros, causando sérios danos à saúde pública e ambiental.

Dados atuais demonstram que enquanto a população mundial cresceu $18 \%$ entre 1970 e 1990 , a produção de resíduos sólidos urbanos aumentou 25\% (19). Esta tendência aliada à crescente urbanizacão. levando à concentração maciça das populacōes humanas nos grandes centros e regiōes metropolitanas (no inicio do século. somente uma em cada dez pessoa vivia em cidades. calcula-se que no ano 2000. a maior parte da população mundial estará habitando centros urbanos)(20), delineia un quadro de graves problemas a serem enfrentados pelos 6rgãos públicos tradicionalmente responsáveis pelas soluções destes, neste caso. as prefeituras municipais.

A reconhecida escassez de recursos financeiros. a falta de planejamento. e a dificuldade de uma visào mais ampla do problema. presentes na maioria absoluta dos municipios brasileiros. tem impossibilitado até hoje os investimentos necessários ao tratamento desta importante questão sob o enfoque da educação e da saúde pública e ambiental. 
Com a agravante da já citada tendência crescente à industrializaçäo. temos atualmente um quadro onde ocorre um esgotamento dos aterros atuais e escassez de áreas adequadas próximas às regiōes metropolitanas, como acontece na capital de São Paulo, onde vemos se agravar o problema de destinação adequada desta imensa quantidade (cerca de 13000 ton/dial(02) de material considerado inútil e potencialmente danoso ao meio ambiente e d saúde das populaçōes envolvidas $(31,52,53)$. Sem contar o absurdo para um país pobre como - nosso. do fato de estarmos enterrando e desperdiçando uma grande quantidade de materiais nobres que poderiam voltar a participar como matéria prima em processos produtivos. economizando energia e recursos naturais.

Entretanto, a quantidade de resíduos sólidos urbanos produzidos varia amplamente ao redor do mundo. Dados da OECD-Organization for Economic Cooperation and Development para meados da década de 80 , mostram que os americanos e os canadenses geravam cerca de duas vezes mais residuos por pessoa que os europeus orientais ou os iaponeses (19).

Até mesmo os documentos do governo americano. citam a nação como a maior produtora mundial de resíduos sólidos urbanos( cerca de $660 \mathrm{k} /$ pessoa em 1988)(19). 
E Importante e premente que sejam realizados trabalhos de esclarecimento e conscientização da nossa população para o problema, objetivando alterar a tendência de cópia do modelo de consumo e descarte norte-americano.

Por sua vez. o cenário mundial envolvendo os estudos. as pesquisas e os posicionamentos of iciais,principalmente nas naçōes industrializadas e de primeiro mundo. compartilha da importância da " hierarquia da administração dos resíduos sólidos" (19).

Esta hierarquia parte de uma lista de opçōes administrativas que devem ser executadas a partir de uma ordem de prioridades: 1) redução nas fontes (evitando em primeiro lugar a geração dos residuos), 2) reutilização dos resíduos gerados lampliação da vida útil de um material ou produto 1. 3 ) reciclagem dos resíduos produzidos (utilização dos resíduos gerados. como matéria prima secundária em processos industriais ou até mesmo artezanais ou naturais de reciclagem :4) incineração com recuperação de energia: 5) aterro (como último recurso. no caso de impossibilidade de qualquer outra opcão anterior. hierarquicamente prioritária).

o termo reciclagem. amplamente usado atualmente a nível nacional e internacional é entretanto novo e 
não consta nas normas da ABNT. optamos entretanto pelo seu uso uma vez que rapidamente ele está sendo incorporado como termo técnico. tendo sido inclusive já utilizado em dissertacōes/teses/relatórios de pós-doutorado, produzidos ou defendidos recentemente $(13,24,43)$. Consideramos neste trabalho como reutilização e reciclagem. o que a ABNT/Associação Brasileira de Normas Técnicas. na sua NBR 9896/1993(07), coloca como recuperacão de recursos de resíduos através de reutilização direta (reutilizaçâo), ou indireta (reciclagem)(07).

Fica claro portanto que qualquer tentativa de busca de efetivas soluções para o problema dos resíduos sólidos urbanos, passa não só por alternativas que envolvam o uso de tecnologias mais limpas e menos poluentes, mas também, por mudanças de hábitos e pelo desenvolvimento de novas at itudes, que envolvam novas posturas, tanto a nível pessoal quanto empresarial e institucional. E estas soluçōes devem vir embasadas em atitudes éticas e integradoras. traduzidas em acões.

E concluindo. me "aproprio" do depoimento entremeado de poesia do jornalista Washington Novaes. extraído do documento do Instituto Brasileiro do Patrimônio Cultural.preparado para a Conferência das Nações Unidas sobre o Meio Ambiente e Desenvolvimento em 1992(68), fazendo minhas as suas palavras sobre a "maestria do lixo." 
"O que é bom para o lixo é bom para a poesia"

" A expressão exata. reveladora, iluminante. é de Manoel de Barros, o mago do Pantanal Matogrossense. poeta dos nadas. das insignificâncias, como ele mesmo se define. E só quem é capaz de ver nos nadas. nas insignificâncias. nas lesmas. nos cacos de vidro. no grilo morto, - lampejo da poesia. é capaz de rasgar o véu das alucinações que nos turvam o olhar do cotidiano e enxergar no lixo o que de fato ali está: a matéria viva. É preciso mesmo rasgar o véu das ilusões que nos conduzem por caminhos perigosos e ameaçam o inconcebível: extinção da vida. E preciso olhar com outros olhos e ver que a insensatez do desperdicio nos leva a supor, como lembra o Prof. José Lutzenberger, que o nosso pequeno $e$ frágil planeta tem de um lado um buraco infinito, do qual extraimos infinitamente recursos: e do outro lado um segundo buraco. no qual at iramos inesgotavelmente a poluição e o lixo que produzimos. Não é assim. Os recursos são finitos, como finita e limitada é a capacidade de suportar devastaçāo, degradaçāo, poluição. Então é preciso fazer do lixo mestre e conselheiro. Aprender. nas suas entranhas, que estamos jogando fora um terço dos materiais de construção. um quarto dos alimentos. Depois, persistir na mesma senda e verificar que metade da água captada nos reservatórios se perde no caminho. no emaranhado dos canos e vazamentos. nảo beneficia ninguém. Constatar que aprisionamos rios e afogamos florestas para desperdiçar quase metade da energia elétrica que eles geram. Nesse caminho, vamos descobrir que estamos desperdicando tudo. E. iunto. as nossas vidas. A vida não precisa ser apenas ânsia de consumo. mesquinharia. Não precisa confinar-nos em gavetas enfumacadas. com medo de tudo e odio dos vizinhos. A vida pode ser outra coisa. outras coisas. Se reaprendermos a respeitá-las. A redescobrir nelas o sagrado que perdenos (quando as fontes eram sagradas. ninguém as poluía). - l ixo pode ser o nosso guia. Com a sua a iuda. conscientes do desperdicio da insensatez, poderemos aprender a economizar recursos. conservar recursos. reciclar recursos. Poderemos voltar a respeitar. Se for assim. vamos redescobrir. com Manoel de Barros. que os rios começan a dormir pela orla. Que flores engordadas nos detritos até falam. Que ovo de lobisomem não tem gema. Que. no lodo. apura o estilo o sapo. Que a elegância e o branco devem muito às garças. Teremos redescoberto. na poesia do lixo. o que é a vida. E quem somos nós". 
II . OBJETIVOS 
De acordo com a Organizaçào Mundial de Saúde : "saude é um estado de completo bem estar físico, mental e social e nào apenas a ausência de doença ou enfermidade"(53).

Esta definição leva em conta que o homem é um ser que se distingue não somente por suas atividades físicas. mas também por seus atributos mentais. espirituais e morais e por sua adaptação ao meio em que vive(52).

Desta forma este trabalho visou detectar de que forma os projetos ou programas de minimização e/ou coleta seletiva de resíduos sólidos urbanos estudados, foram capazes de atuar favoravelmente na saúde integral das populações envolvidas, incluindo como beneficios, todas as ações/comportamentos/atitudes capazes de contribuir co̊ a preservação e a saúde ambiental, o desenvolvimento da cidadania e a participação de todos os envolvidos. na busca de uma melhor qualidade de vida.

$$
\text { Visou ainda fornecer subsidios que }
$$

auxiliem experiências desta natureza.assim como programas futuros. na concretizaçào desses ob.jetivos. 
III. REVISAOO BIBLIOGRAFICA 
III.1. RESIDUOS SOLIDOS URBANOS: UM NOVO OU ANTIGO PROBLEMA ?

A história dos residuos sólidos parece se confundir com a própria história do homem urbano. Na idade média dizia-se que as cidades fediam. os restos $e$ os dejetos eram jogados em lugares distantes(52.68)onde. parafraseando o filme "Ilha das Flores"(*), pudessem livremente sujar, cheirar mal e atrair doenças". Menciona-se também na história antiga que além da prática do lançamento dos resíduos a céu aberto e em cursos d'água, enterrava-se e usava-se o fogo para a destruição dos restos inaproveitáveis (52).

No Brasil a situação não foi muito diferente.As primeiras cidades brasileiras mais populosas não primavam pela limpeza. Na cidade do Rio de Janeiro as primeiras normas públicas criadas proibiam o lançamento de resíduos e deietos nas ruas e era incumbência dos escravos levar esse material inservível para locais mais distantes(68).

*) Il ha das Flores - filme curta metragem, dirigido por Jorge Furtado, é ganhador de vários prêmios nacionais e internacionais, e trata de forma extremamente sensível do uso e da disposição inadequada dos resíduos sólidos urbanos da cidade de Porto Alegre. RS. 
São Paulo também tinha suas normas.

Rocha(66) nos conta que entre os anos de 1721 e 1737 muitos

editais conclamavam à limpeza. Um edital especialmente

interessante de 15 de outubro de 1722 dizia:

" Os of iciais do Senado da Câmara desta cidade de São Paulo que presente ao servimos pela ordenação de Sua Majestade que Deus guarde,fazemos saber a todos os moradores desta cidade.de qualquer qualidade e condição que sejam,que daqui em diante façam botar os ciscos e os lixos de suas casas nas paragens declaradas.a saber.nas covas que ficam abaixo das casas de Garcia Roiz Velho e nas covas que estão atrás da Misericórdia Nova e nas covas que estão defronte de Santa Tereza e somente o facam nestas paragens $e$ as pessoas que fora destes lugares botarem os tais lixos seräo condenadas por cada vez em seis mil réis sem que thes sirva de desculpa o ignorarem onde seus servos botan os tais lixos. pois o deverão examinar e fazer executar como pelo que o presente quartel ordenamos".

Muitas vezes os resíduos das casas da região central da cidade (constituídos basicamente de restos de alimentos.cascas de frutas, e alguns poucos objetos) eram recolhidos pelos chacareiros da zona rural para alimentação de porcos ou adubação de verduras. Em 1869 a Câmara do Município (naquela época nào havia prefeito) contratou um carroceiro para apanhar o lixo das casas. pois os chacareiros estavam preferindo coletar apenas os lixos mais ricos dos restaurantes. hotéis e bares $(39)$.

No Rio de Janeiro do final do século um comerciante. A. Gari. se destacou nesse tipo de serviço: responsavel pela prestacāo dos servicos de limpeza urbana durante dez anos legou seu nome aos coletores de lixo. os famosos "garis" do Rio de Janeiro(68). Em 1900. Luís Edmundo, cronista da época. 
comentava a respeito dessa nossa Capital da República: "A cidade ainda guarda o cunho desolador dos velhos tempos do rei. dos vice-reis e dos governadores, com ruas estreitas, vielas sujissimas. becos onde se avoluma o lixo...cascas de abacaxi. de larania. papéis velhos. molambos". (66).

Até algumas décadas atrás a limpeza urbana era de responsabilidade dos serviços de higiene e saúde das prefeituras e consistia exclusivamente na coleta e destinaçao dos resíduos dispostos pela população nas calçadas, evitando dessa forma a proliferaçāo de vetores e consequentemente a transmissão de doencas. Excetuando-se os potenciais problemas de saude pública. poucos impactos causavam ao ambiente, uma vez que biodegradáveis retornavam aos ciclos naturais e eram reincorporados ao solo. Nessa época as cidades eram menores e a quantidade produzida por pessoa também era menor(71). sem contar que mesmo nos centros urbanos era muito comum a criação de animais e a adubação das plantas com as sobras e restos domésticos. 
III.2. MAS HOJE. O QUE SAOO OS RESIDUOS SOLIDOS URBANOS ?

RESIDUO: MATERIAL OU RESTO DE MATERIAL CUJO PROPRIETARIO OU PRODUTOR NAO MAIS O CONSIDERA COM VALOR SUFICIENTE PARA CONSERVA-LO, de acordo com a ABNT(07),

ou

RESIDUO SOLIDO: RESIDUO DAS ATIVIDADES HUMANAS, QUE NORMALMENTE SE APRESENTA EM ESTADO SOLIDO, SEMI SOLIDO OU SEMILIQUIDO. E E VULGARMENTE DENOMINADO LIXO, ainda de acordo com a ABNT (07).

$$
\text { ou ainda }
$$

\footnotetext{
RESIDUO SOLIDO: MATERIAL INUTIL. INDESEJAVEL OU DESCARTADO. COM CONTEUDO LIQUIDO INSUFICIENTE PARA QUE POSSA INFLUIR LIVREMENTE NOS ESTADOS SOLIDO E SEMI-SOLIDO RESULTANTES DE ATIVIDADES DA COMUNIDADE. SEJAM ELES DE ORIGEM DOMESTICA. HOSPITALAR. COMERCIAL. DE SERVICOS. DE VARRICAO E INDUSTRIAL" ( 12$)$.
} 
LIXO: 1. AQUILO QUE SE VARRE DA CASA.DO JARDIM. DA RUA E SE JOGA FORA:ENTULHO.2.TUDO O QUE NAO PRESTA E SE JOGA FORA.3.SUJIDADE. SUJEIRA. IMUNDICIE.4.COISA OU COISAS INUTEIS VELHAS.SEM VALOR. 1421 de acordo com um famoso dicionarista.

ou uma definiçāo mais recente

LIXO: UM SUBPRODUTO DO CONJUNTO DE ATIVIDADESDESENVOLVIDAS PELA SOCIEDADE COM O OBJETIVO DE ATENDER SUAS NECESSIDADES DE CONSUMO(55) de acordo com a visão atual de uma prefeitura municipal.

Mas os resíduos urbanos estão crescendo e evoluindo, e de massa orgànica em decomposicão passaram à massa heterogènea, onde esta matéria organica convive com uma série de outros materiais, que adicionaram impactos ambientais e sociais às consequências de um tratamento nāo adequado. Dados da Prefeitura do Municipio de São Paulo demonstram esta mudanca qualitativa recente(tabela 11 . 


\begin{tabular}{|c|c|c|c|c|c|}
\hline $\begin{array}{r}\text { EVOLUÇAO DA COR } \\
\text { DA }\end{array}$ & $\begin{array}{l}\text { SICAOO G } \\
\text { ADE DE }\end{array}$ & $\begin{array}{l}\text { ABELA } 1 \\
\text { VIMETR } \\
\text { O PAUL }\end{array}$ & $\begin{array}{l}\text { (\%) DO } \\
\text { E } 1927 \mathrm{~A}\end{array}$ & RStDUOS & IBANOS \\
\hline COMPONENTES & 1927 & 1957 & 1969 & 1976 & 1991 \\
\hline Mald́ria Organica & 82,50 & 76,00 & 52,20 & 62,70 & 60,60 \\
\hline Pepol/Papoläolfornal & 13,40 & 16,70 & 29,20 & 21,40 & 13,87 \\
\hline Plásico duro/Filme & $\cdots$ & $\cdots$ & 1,90 & 5,00 & 11,47 \\
\hline Malal Porroso & 1,70 & 2.23 & 7,80 & 3,90 & 2.83 \\
\hline Malal narroeo & - & $\cdots$ & -- & 0,10 & 0,69 \\
\hline Trapos/Couro/Borracha & 1,50 & 2,70 & 3,80 & 2,90 & 4,39 \\
\hline Vidros & 0,90 & 1.40 & 260 & 1.70 & 1.69 \\
\hline Torra/Padras & $\cdots$ & -- & $\cdots$ & 0,70 & 0,77 \\
\hline Madeira & $\cdots$ & $\cdots$ & 240 & 1,60 & 0,75 \\
\hline Diversos & $\cdots$ & 0,10 & $\ldots$ & $\cdots$ & $\cdots$ \\
\hline Pendas & $\cdots$ & $\cdots$ & $\cdots$ & $\cdots$ & 1,71 \\
\hline Poso Espocifico $\left(\mathrm{kg} / \mathrm{m}^{3}\right)$ & 500 & 300 & 230 & $\ldots$ & 234 \\
\hline
\end{tabular}

Fonte: CEMPRE ( 02) 


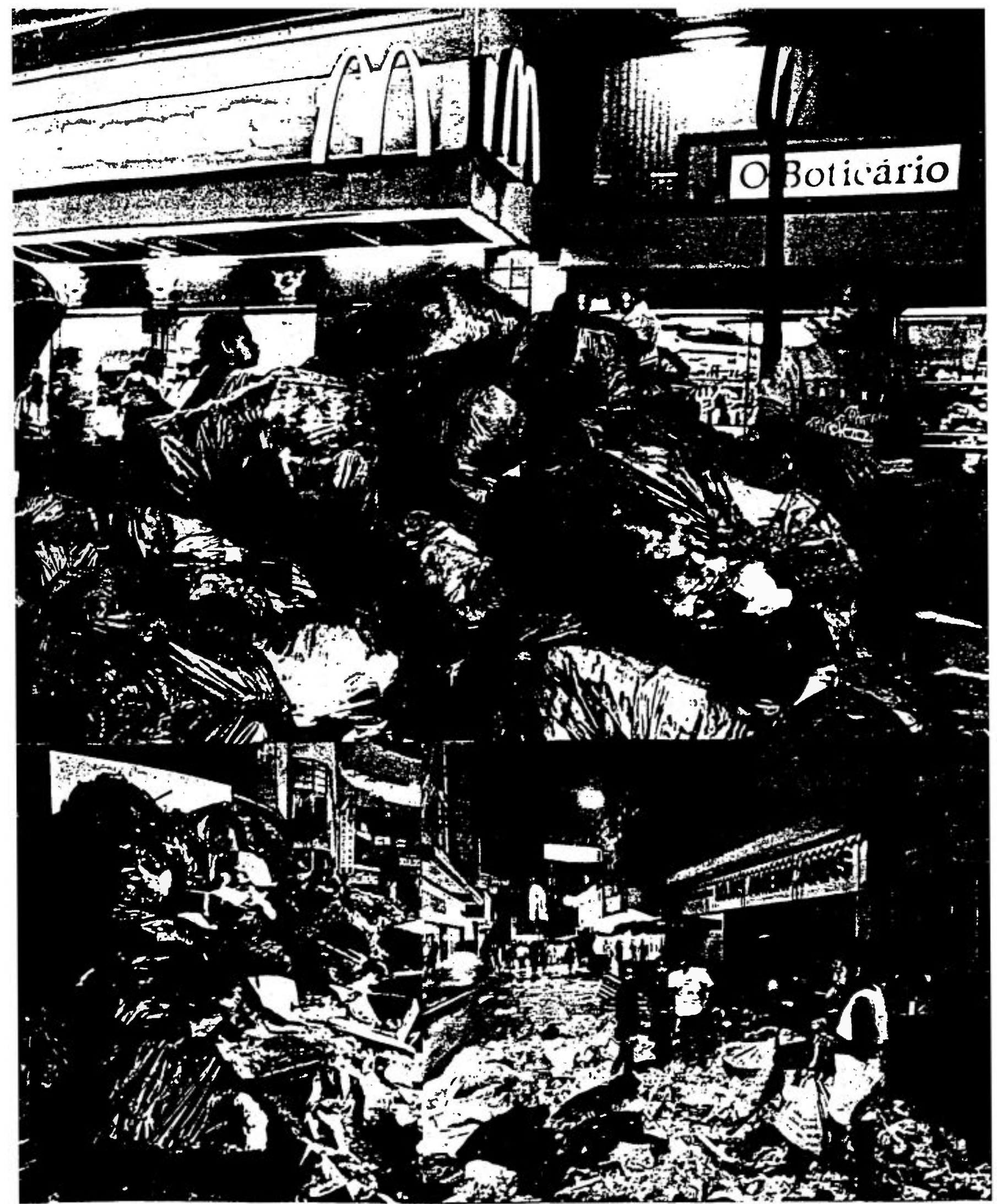




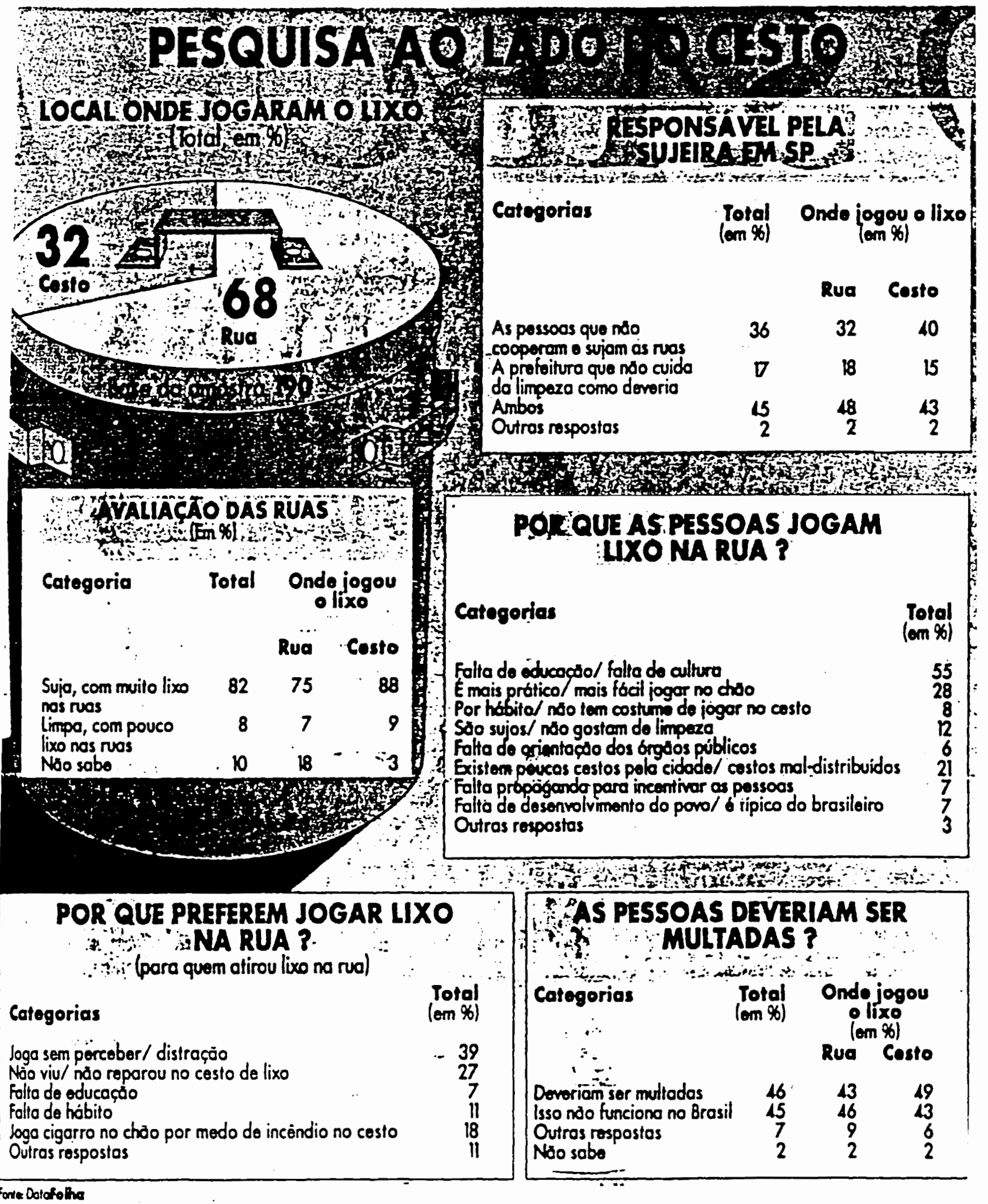


III.3. MAS E HOJE. COMO A POPULAÇATO VE OS RESIDUOS SOLIDOS URBANOS ?

Para a nossa população qualquer resíduo, material inservivel ou lixo é algo que deve ser descartado imediatamente e o destino parece fugir da sua responsabilidade. Dois exemplos distintos mostram que no Brasil, tanto pessoas físicas quanto jurídicas, nảo tem muito claro o conceito de cidadania e de respeito aos lugares públicos.

A pesquisa da página anterior, realizada pela Datafolha e publicada em 14 de abril de 1991(Jornal Folha de São Paulo-14/04/91). constatou que jogar comodamente na rua o que é considerado inútil, persiste como hábito da maioria dos paulistanos.

Foi constatado que $68 \%$ descartam seus residuos ou lixos em qualquer lugar. enquanto $32 \%$ procuram um coletor apropriado.Dos que admitem descartá-los no chão. 39\% dizem ser por distração, $27 \%$ por não terem visto a lixeira, $11 \%$ por falta de hábito e $7 \%$ falta de educação.

Mas na realidade a convivência com a sujeira não é tão tranquila como pode parecer à primeira 
inpressaio. $82 \%$ da populacảo se mostrou insatisfeita com a I impeza urbana, avaliando a cidade "como suja, com muito lixo nas ruas" e a maioria (51\%) se mostrou incomodada com esta si tuacảo.

Também a questão da responsabilidade apareceu dividida: $36 \%$ apontou a "população que não coopera e su.ja as ruas".17\% destacou"a prefeitura que não cuida da limpeza como deveria" e $45 \%$ acredita que é de ambos.

Para a população pesquisada o fato da maioria descartar tranquilamente e em qualquer lugar os seus residuos ou lixos. está ligado à falta de educação e de cultura (55\%).à praticidade de nāo ter que procurar o cesto (28\%) e à insuficiente e má distribuição dos cestos pela cidade $(21 \%)$.

Se observarmos ainda que $7 \%$ se manifestou como sendo falta de desenvolvimento do povo e ser típico do brasileiro este tipo de atitude. vemos claramente a péssima impressão que as pessoas têm delas mesmas e a conotação negativa que é dada à este hábito arraigado entre nós.

Destacou-se ainda que os órgãos públicos deveriam orientar melhor a população $(6 \%)$. e que taltam campanhas de conscientização para educar melhor as pessoas. 
A aplicação de multas como forma de se tentar resolver a questão teve praticamente a mesma taxa de apoio e rejeicāo, $46 \%$ e $45 \%$ respectivamente. Na realidade a Lei Municipal 10.746, de 1989, determina multa de 20 Unidades Fiscais do Município para este tipo de ação, que já é considerada infracão.

Na realidade nos parece mais simples e econòmico o investimento em mobilização e educação, do que a contrataçào absurda de uma imensa equipe de fiscais capazes de punir os flagrantes. Isso sem contar o volume de recursos já dispendidos com a varrição na cidade de São Paulo.

Em novembro de 1992 a revista Veja registrou inúmeros casos onde estabelecimentos comerciais descumprindo várias leis. emporcalhavam a cidade abandonando grandes quantidades de resíduos sobre as calçadas, propiciando um triste banquete aos mendigos da região e uma corrida aos restos que pudessem ser vendidos(latas.papéis.papelào, vidros.etc).

Como consequência sobravam rastros de suieira. e mais trabalho aos coletores e varredores, e na realidade. essas empresas (entre elas MacDonalds, Lojas Americanas e Restaurante The Placel além de colocarem seus residuos ou lixos de forma irregular. descumpriam a legislaça duplamente pois só estabelecimentos comerciais que produzem até $110 \mathrm{~kg} / \mathrm{dia}$ podem utilizar a coleta pública.Para os demaıs a responsabilidade é da própria fonte geradora.que deve 
custear a coleta e a destinação adequada.Nestes espaços podemos identificar quem.como declarou a ex-Secretária Municipal de Cultura Marilena Chaui. "privatiza o que é público e näo percebe a rua como espaço social e comum a todos "(Revista Veja-11/92). 
III.4. MAS PARA ONDE VAOO OS RESIDUOS SOLIDOS URBANOS

Se estes resíduos espalhados pela cidade já são um problema de difícil solução, capazes de gerar uma série de outros.o que nào dizer de todos os resíduos sólidos urbanos que deveriam ser adequadamente coletados, tratados e/ou dispostos.

Recentes estudos realizados por Figueiredo(43) a partir de pesquisa própria e fontes diversas, revelaram existir uma variação com relação à porcentagem da populacào que é realmente atendida por esses serviços(tabela 2 ). Fica claro que uma grande parcela da populaçāo urbana principaimente nas regiões Nordeste e Centro oeste não é atendida(inclusive nas capitais dos estados) o que nos leva a supor que as condicoes dos municipios menores sejam ainda mais precarias.

A maior parte destes resíduos coletados na grande maioria dos municípios brasileiros é disposta a céu aberto não recebendo nenhum tipo de tratamento (tabela 3 ). 
- próprio Estado de São Paulo não apresenta um quadro muito diferente: dados recentes da CETESB/Companhia de Tecnologia de Saneamento Ambientalltabelas 5 , 6 e 7lregistram uma situação alarmante, onde a grande maioria dos municipios também dispōe seu lixo a céu aberto sem nenhum tratamento, o que vem sendo cada vez mais combatido pela populacão, por entidades ambientalistas, pela Curadoria do Meio Ambiente e pela própria CETESB.

Cada vez mais as prefeituras municipais, únicas responsáveis por toda a coleta dos resíduos sólidos urbanos e, na maior parte das vezes, também pelos outros tipos de resíduos gerados nos seus municípios, são sobrecarregadas com a crescente quantidade de lixo a ser coletada, tratada e/ou destinada adequadamente.

De acordo com Souza e Silva ( 71 ) em 1890 para a população da cidade de São Paulo com 240000 habitantes eram coletadas 99 toneladas diárias de resíduos sólidos urbanos. o que correspondia a $0.40 \mathrm{Kg}$ por pessoa: hoje coletam-se cerca de 13000 toneladas /dia, produzidas por cerca de 11 milhōes de habitantes. dando uma média por cidadão de aproximadamente $1 \mathrm{Kg} / \mathrm{dia}(02.43)$. 
Sabendo-se que cidades mais industrializadas apresentam quantidades maiores de resíduos sólidos urbanos per capita(19). estima-se que a média estaria entre 500/800 g dia. Estudos recentes de Figueiredo (43) chegaram a $819 \mathrm{~g} / \mathrm{dia}$, tendo a maior parte dos pequenos e médios municípios.valores intermediários entre os estes valores(tab. 4 ).

Esses dados mostram que realmente o problema é extremamente sério e tende a se ampliar, tanto pelo aumento da geração de resíduos,quanto pela maior conscientização da população, que cada vez mais rejeita a idéia de $l$ ixões e mesmo aterros próximos às suas casas.

\section{A crescente tendência à urbanização} observada em todo o mundo(20) aparece ainda como fator agravante dessa situacào. assim como o aumento da população. Estima-se que haverá um acréscimo de pelo menos 960 milhões de pessoas à populacào mundial na década de 90. maior do que o da década de 80 e 70 . que foram respectivamente de aproximadamente 840 e 750 mi lhòes $(19.45)$. 


\begin{tabular}{|c|c|c|c|c|c|c|}
\hline \multicolumn{7}{|c|}{ RESTDUOS SOLLDOS URBANOS EM ALGUMAS CIDADRS BRASILEIRAS } \\
\hline$C I D A D E$ & Estado & $\begin{array}{c}\text { Populagio } \\
\text { Übana }\end{array}$ & $\begin{array}{l}\text { Populagio } \\
\text { Atendida }\end{array}$ & $\begin{array}{l}\text { Qunat. de } \\
\text { Realduo } \\
\text { Coldado } \\
\text { (tos/dia) } \\
\end{array}$ & Fonte & $\begin{array}{l}\text { Anoda } \\
\text { Penquile }\end{array}$ \\
\hline $\begin{array}{l}\text { Cach. do ltapernerim } \\
\text { Vitória } \\
\text { Araguari } \\
\text { Barbacena }\end{array}$ & $\begin{array}{l}\text { ES } \\
\text { ES } \\
\text { MO } \\
\text { MG }\end{array}$ & $\begin{array}{r}106690 \\
254448 \\
100000 \\
84683\end{array}$ & $\begin{array}{c}70 \approx 90 \\
70 \approx 90 \\
40 \approx 60 \\
100\end{array}$ & $\begin{array}{r}120,00 \\
180,00 \\
60,00 \\
18,00\end{array}$ & $\begin{array}{l}\text { BNDES } \\
\text { BNDES } \\
\text { BNDES } \\
\text { BNDES }\end{array}$ & $\begin{array}{l}1985 \\
1985 \\
1985 \\
1985\end{array}$ \\
\hline $\begin{array}{l}\text { Belo Horizonte } \\
\text { Betim } \\
\text { Popos de Caldas } \\
\text { Vipose }\end{array}$ & $\begin{array}{l}\text { MG } \\
\text { MO } \\
\text { MG } \\
\text { MG }\end{array}$ & $\begin{array}{r}2122073 \\
112000 \\
81448 \\
44814\end{array}$ & $\begin{array}{c}70290 \\
40=60 \\
70=90 \\
\ldots\end{array}$ & $\begin{array}{r}1.100,00 \\
65,00 \\
41,00 \\
20,00\end{array}$ & $\begin{array}{l}\text { BNDES } \\
\text { BNDES } \\
\text { BNDES } \\
\text { PMMP }\end{array}$ & $\begin{array}{l}1985 \\
1985 \\
1985 \\
1988\end{array}$ \\
\hline $\begin{array}{l}\text { Itaboraf } \\
\text { Rocondo } \\
\text { Rio do Janeiro } \\
\text { Sto Joso do Moriti }\end{array}$ & $\begin{array}{l}R J \\
R J \\
R J \\
R\end{array}$ & $\begin{array}{r}144945 \\
68072 \\
5109496 \\
398828\end{array}$ & $\begin{array}{l}40=60 \\
70=90 \\
70=90 \\
10=30\end{array}$ & $\begin{array}{r}10,00 \\
30,00 \\
4.300,00 \\
30,00\end{array}$ & $\begin{array}{l}\text { BNDES } \\
\text { BNDES } \\
\text { BNDES } \\
\text { BNDES }\end{array}$ & $\begin{array}{l}1985 \\
1985 \\
1985 \\
1985\end{array}$ \\
\hline $\begin{array}{l}\text { Teresoolis } \\
\text { Amstioana } \\
\text { Buun } \\
\text { Campinas }\end{array}$ & $\begin{array}{l}R \\
\text { SP } \\
\text { SP } \\
\text { SP }\end{array}$ & $\begin{array}{r}88252 \\
200000 \\
260000 \\
1000000\end{array}$ & $\begin{array}{c}10=60 \\
100 \\
100\end{array}$ & $\begin{array}{r}31,00 \\
100,00 \\
140,00 \\
800,00\end{array}$ & $\begin{array}{l}\text { BNDBS } \\
\text { LMQL } \\
\text { PMMP } \\
\text { LMQL }\end{array}$ & $\begin{array}{l}1985 \\
1988 \\
1989 \\
1985\end{array}$ \\
\hline $\begin{array}{l}\text { Guaratingudtá } \\
\text { Marnia } \\
\text { Mogi das Cruese } \\
\text { Piracicaba }\end{array}$ & $\begin{array}{l}\text { SP } \\
\text { SP } \\
\text { SP } \\
\text { SP }\end{array}$ & $\begin{array}{r}94340 \\
145000 \\
207692 \\
278000\end{array}$ & $\begin{array}{c}100 \\
100 \\
100 \\
\cdots\end{array}$ & $\begin{array}{r}70,00 \\
73,00 \\
92,00 \\
150,00\end{array}$ & $\begin{array}{l}\text { BNDES } \\
\text { BNDES } \\
\text { BNDES } \\
\text { PJMF }\end{array}$ & $\begin{array}{l}1985 \\
1985 \\
1985 \\
1989\end{array}$ \\
\hline $\begin{array}{l}\text { Praiz Grande } \\
\text { Prasidente Prudento } \\
\text { Rio Claro } \\
\text { Samtos }\end{array}$ & $\begin{array}{l}\text { SO } \\
\text { SP } \\
\text { SP } \\
\text { SP }\end{array}$ & $\begin{array}{l}60000 \\
170000 \\
104091 \\
461096\end{array}$ & $\begin{array}{c}80 \\
70290 \\
70290 \\
100\end{array}$ & $\begin{array}{r}40,00 \\
90,00 \\
52,00 \\
340,00\end{array}$ & $\begin{array}{l}\text { LMQL } \\
\text { BNDES } \\
\text { BNDES } \\
\text { BNDES }\end{array}$ & $\begin{array}{l}1985 \\
1985 \\
1985 \\
1985\end{array}$ \\
\hline $\begin{array}{l}\text { R.M.S.P } \\
\text { Sumard } \\
\text { Szo J.dos Campos } \\
\text { Szo Roque }\end{array}$ & $\begin{array}{l}S P \\
S P \\
S P \\
S P\end{array}$ & $\begin{array}{r}14735194 \\
220000 \\
3833607 \\
60000\end{array}$ & $\begin{array}{l}\cdots \\
100 \\
100\end{array}$ & $\begin{array}{r}15.100,00 \\
46,00 \\
150,00 \\
40,00\end{array}$ & $\begin{array}{l}\text { EMPLASA } \\
\text { PMMP } \\
\text { BNDES } \\
\text { LMQL }\end{array}$ & $\begin{array}{l}1986 \\
1988 \\
1985 \\
1989\end{array}$ \\
\hline $\begin{array}{l}\text { Brasilia } \\
\text { Cuiabá } \\
\text { Macoió } \\
\text { Illhtus }\end{array}$ & $\begin{array}{l}\text { DF } \\
\text { MT } \\
\text { AL } \\
\text { BA }\end{array}$ & $\begin{array}{r}1567709 \\
450000 \\
551732 \\
80685\end{array}$ & $\begin{array}{c}40=60 \\
70= \\
-.\end{array}$ & $\begin{array}{r}1.000,00 \\
200,00 \\
300,00 \\
60,00\end{array}$ & $\begin{array}{l}\text { MSP } \\
\text { BNDES } \\
\text { PJMP } \\
\text { BNDES }\end{array}$ & $\begin{array}{l}1972 \\
1985 \\
1988 \\
1985\end{array}$ \\
\hline $\begin{array}{l}\text { Salvador } \\
\text { Fortal wea } \\
\text { Campina Orando }\end{array}$ & $\begin{array}{l}\mathrm{BA} \\
\mathrm{CE} \\
\mathrm{PB}\end{array}$ & $\begin{array}{r}1800000 \\
1732319 \\
307171\end{array}$ & $\begin{array}{l}70=90 \\
70=90 \\
40=60\end{array}$ & $\begin{array}{r}2.100,00 \\
1.290,00 \\
150,00\end{array}$ & $\begin{array}{l}\text { BNDES } \\
\text { BNDES } \\
\text { PMMP }\end{array}$ & $\begin{array}{l}1985 \\
1985 \\
1988\end{array}$ \\
\hline
\end{tabular}




\begin{tabular}{|c|c|c|c|c|c|c|}
\hline REStDUOS SC & brimos & $\begin{array}{l}\text { URBANOS } \\
\text { (Co }\end{array}$ & $\begin{array}{l}\text { IBRAA } 2 \\
\text { RM ALGU } \\
\text { ntinusio) }\end{array}$ & MAS CIDA & $8 \mathrm{BRA}$ & RAs. \\
\hline CIDADE & Bxado & $\begin{array}{c}\text { Populagio } \\
\text { Ubana }\end{array}$ & $\begin{array}{l}\text { Populacio } \\
\text { Atondida }\end{array}$ & $\begin{array}{l}\text { Quant. de } \\
\text { Rexideo } \\
\text { Calutado } \\
\text { (ton/dia) } \\
\end{array}$ & Fonte & $\begin{array}{l}\text { Ano da } \\
\text { Penquina }\end{array}$ \\
\hline $\begin{array}{l}\text { Teresina } \\
\text { Mossoń } \\
\text { Natal } \\
\text { Aracaju }\end{array}$ & $\begin{array}{l}\text { PI } \\
\text { RN } \\
\text { RN } \\
\text { SE }\end{array}$ & $\begin{array}{l}498813 \\
215918 \\
547900 \\
387200\end{array}$ & $\begin{array}{l}70 \therefore 90 \\
40 \therefore 60 \\
40 a 60 \\
40 \therefore 60\end{array}$ & $\begin{array}{l}980,00 \\
175,00 \\
600,00 \\
200,00\end{array}$ & $\begin{array}{l}\text { BNDES } \\
\text { BNDES } \\
\text { BNDES } \\
\text { BNDES }\end{array}$ & $\begin{array}{l}1985 \\
1985 \\
1985 \\
1988\end{array}$ \\
\hline $\begin{array}{l}\text { Manaus } \\
\text { Apuoarana } \\
\text { Arapongas } \\
\text { Arwuesria }\end{array}$ & $\begin{array}{l}A M \\
P R \\
P R \\
P R\end{array}$ & $\begin{array}{r}1800000 \\
86805 \\
48200 \\
28000\end{array}$ & $\begin{array}{c}70= \\
\ldots \\
\ldots\end{array}$ & $\begin{array}{r}1.000,00 \\
22,00 \\
35,00 \\
30,00\end{array}$ & $\begin{array}{l}\text { LMQL } \\
\text { BNDBS } \\
\text { BNDES } \\
\text { PJMP }\end{array}$ & $\begin{array}{l}1985 \\
1985 \\
1985 \\
1988\end{array}$ \\
\hline $\begin{array}{l}\text { Campo Mouräo } \\
\text { Corntlio Prootpio } \\
\text { Curitiba Rez.Mdrop. } \\
\text { Pranoisoo Boltra. }\end{array}$ & $\begin{array}{l}\mathrm{PR} \\
\mathrm{PR} \\
\mathrm{PR} \\
\mathrm{PR}\end{array}$ & $\begin{array}{r}59210 \\
32000 \\
1500000 \\
29000\end{array}$ & $70 \stackrel{\ldots}{\ldots}$ & $\begin{array}{r}29,00 \\
20,00 \\
425,00 \\
13,00\end{array}$ & $\begin{array}{l}\text { PJMP } \\
\text { PJMP } \\
\text { PJMP } \\
\text { PMMP }\end{array}$ & $\begin{array}{l}1988 \\
1988 \\
1988 \\
1988\end{array}$ \\
\hline $\begin{array}{l}\text { Guarzparya } \\
\text { lbipor" } \\
\text { Londrina } \\
\text { Parangar }\end{array}$ & $\begin{array}{l}\text { PR } \\
\text { PR } \\
\text { PR } \\
\text { PR }\end{array}$ & $\begin{array}{r}135000 \\
22000 \\
300000 \\
90000\end{array}$ & $\cdots$ & $\begin{array}{r}45,00 \\
11,00 \\
140,00 \\
43,00\end{array}$ & $\begin{array}{l}\text { PJMP } \\
\text { PJMP } \\
\text { PJMP } \\
\text { PJMP }\end{array}$ & $\begin{array}{l}1988 \\
1988 \\
1988 \\
1988\end{array}$ \\
\hline $\begin{array}{l}\text { Ponta Grossa } \\
\text { Tolamaco Borba } \\
\text { Tolado } \\
\text { Umuarama }\end{array}$ & $\begin{array}{l}P R \\
P R \\
P R \\
P R\end{array}$ & $\begin{array}{r}228312 \\
36000 \\
43000 \\
81952\end{array}$ & $\begin{array}{c}100 \\
70= \\
70 \\
\ldots\end{array}$ & $\begin{array}{l}95,00 \\
18,00 \\
23,00 \\
46,00\end{array}$ & $\begin{array}{l}\text { PJMP } \\
\text { PJMP } \\
\text { PJMP } \\
\text { PJMP }\end{array}$ & $\begin{array}{l}1988 \\
1988 \\
1988 \\
1988\end{array}$ \\
\hline $\begin{array}{l}\text { Unizá da Vitória } \\
\text { Novo Hamburgo } \\
\text { Passo Rundo } \\
\text { Polctas }\end{array}$ & $\begin{array}{l}\text { PR } \\
\text { RS } \\
\text { RS } \\
\text { RS }\end{array}$ & $\begin{array}{r}83500 \\
164411 \\
99400 \\
259980\end{array}$ & $\begin{array}{c}\ldots \\
70 \& 90 \\
70=90\end{array}$ & $\begin{array}{r}20,00 \\
90,00 \\
64,00 \\
120,00\end{array}$ & $\begin{array}{l}\text { PJMP } \\
\text { BNDES } \\
\text { BNDES } \\
\text { PJMP }\end{array}$ & $\begin{array}{l}1988 \\
1985 \\
1985 \\
1989\end{array}$ \\
\hline $\begin{array}{l}\text { Porto Alegro } \\
\text { Rio Grande } \\
\text { Santa Maria } \\
\text { Sant2 Cruz do Sul }\end{array}$ & $\begin{array}{l}\text { RS } \\
\text { RS } \\
\text { RS } \\
\text { RS }\end{array}$ & $\begin{array}{r}1263459 \\
236000 \\
185000 \\
63353\end{array}$ & $\begin{array}{c}100 \\
70290 \\
\cdots \\
70290\end{array}$ & $\begin{array}{r}600,00 \\
104,00 \\
80,00 \\
46,00\end{array}$ & $\begin{array}{l}\text { BNDES } \\
\text { BNDES } \\
\text { PMMP } \\
\text { BNDES }\end{array}$ & $\begin{array}{l}1985 \\
1985 \\
1988 \\
1985\end{array}$ \\
\hline $\begin{array}{l}\text { Santo Angelo } \\
\text { Chapeo6 } \\
\text { Criciúm } \\
\text { Ploriantpolis }\end{array}$ & $\begin{array}{l}\text { RS } \\
\text { SC } \\
\text { SC } \\
\text { SC }\end{array}$ & $\begin{array}{r}62855 \\
69941 \\
110604 \\
232750\end{array}$ & $\begin{array}{c}100 \\
70: 90 \\
70.90 \\
100\end{array}$ & $\begin{array}{r}60,00 \\
60,00 \\
80,00 \\
250,00\end{array}$ & $\begin{array}{l}\text { BNDES } \\
\text { BNDES } \\
\text { BNDES } \\
\text { BNDES }\end{array}$ & $\begin{array}{l}1985 \\
1985 \\
1985 \\
1985\end{array}$ \\
\hline $\begin{array}{l}\text { Ilajar } \\
\text { Joinvilo } \\
\text { Lages }\end{array}$ & $\begin{array}{l}\text { SC } \\
\text { SC } \\
\text { SC }\end{array}$ & $\begin{array}{r}80115 \\
329908 \\
117717\end{array}$ & $\begin{array}{l}70290 \\
70290 \\
70290\end{array}$ & $\begin{array}{r}120,00 \\
180,00 \\
45,00\end{array}$ & $\begin{array}{l}\text { BNDES } \\
\text { BNDES } \\
\text { BNDES }\end{array}$ & $\begin{array}{l}1985 \\
1985 \\
1985\end{array}$ \\
\hline
\end{tabular}

Ponte: FIGURIRRDO (43) 


\begin{tabular}{|c|c|c|c|c|c|c|c|}
\hline \multicolumn{8}{|c|}{ DEST WO DOS RESTDUOSSOLIDOS ORBANOS DE A LGUMAS CEA DES BRASTLERAS. } \\
\hline CDADI & $\begin{array}{c}\text { Doposa } \\
\text { Cen } \\
\text { Aberw }\end{array}$ & 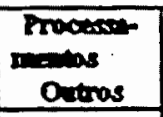 & $\begin{array}{l}\text { Popninglo } \\
\text { Corrtiten }\end{array}$ & $\begin{array}{l}\text { Qunte } \\
\text { Rextho } \\
\text { on/4n }\end{array}$ & $\begin{array}{c}\text { Cen } \\
\text { Alem } \\
\text { covela }\end{array}$ & $\begin{array}{l}\text { Ontras } \\
\text { conitie }\end{array}$ & $\begin{array}{c}\text { Sem } \\
\text { homm } \\
\text { wolle }\end{array}$ \\
\hline Cech do thememinim & 100 & & 106690 & 120 & 120 & 이 & \\
\hline Vitoria & 100 & & 254448 & 179 & 179 & a) & \\
\hline Araguari & 100 & & $\begin{array}{r}100000 \\
64683\end{array}$ & 60 & 60 & 0 & \\
\hline Diracom & & & & iv & 10 & 1 & \\
\hline $\begin{array}{l}\text { Balo Harizante } \\
\text { Botim }\end{array}$ & 100 & & $\begin{array}{r}2122073 \\
112000\end{array}$ & $\begin{array}{r}1099,2 \\
65\end{array}$ & $\begin{array}{r}0 \\
65\end{array}$ & 0 & 1099.2 \\
\hline Pogos do Caldes & 10 & & 81448 & 41 & 4,1 & 0 & 36,9 \\
\hline Yifon & 100 & & 44814 & 20 & 20 & o) & \\
\hline $\begin{array}{l}\text { Itabosei } \\
\text { Ropondes }\end{array}$ & 100 & & $\begin{array}{r}144945 \\
68072\end{array}$ & $\begin{array}{l}10 \\
30\end{array}$ & $\begin{array}{r}0 \\
30\end{array}$ & $\begin{array}{l}0 \\
0\end{array}$ & 10 \\
\hline Rio de tanoiro & 9 & & 5109496 & 43022 & 387,2 & 0 & 3915 \\
\hline Sra Jä́o do Moditi & 40 & & 398828 & 29,9 & 12 & of & 179 \\
\hline $\begin{array}{l}\text { Theospolle } \\
\text { Americense }\end{array}$ & 100 & & $\begin{array}{r}88252 \\
185529\end{array}$ & $\begin{array}{r}31 \\
92.8\end{array}$ & $\begin{array}{r}31 \\
0\end{array}$ & 0 & 92,8 \\
\hline Banu & 100 & & 235225 & 126,6 & 126,6 & 0 & \\
\hline Campion & & 100 & 1000000 & 845 & 0 & 845.00 & \\
\hline Oundingums & & & 94340 & 70 & o. & 0 & 70 \\
\hline Marmia & & & 1450000 & 729 & 0 & o) & 729 \\
\hline Mogi das Crumos & & & 207692 & 92 & o) & 0 & 92 \\
\hline Precicabe & 100 & & 251510 & 135,8 & 135,8 & 0) & \\
\hline Prail Orends & & & 60000 & 40 & 0 & 0 & 40 \\
\hline Precidonte Prudanto & & & 170000 & 89.9 & 0) & ㅇ) & 89,9 \\
\hline Rio Claro & & & 104091 & 52 & 0 & 0 & 52 \\
\hline Senton & & & 461096 & 339,8 & 0) & 이 & 339,8 \\
\hline $\begin{array}{l}\text { RMSP } \\
\text { Sumod }\end{array}$ & 32 & $\begin{array}{l}68 \\
100\end{array}$ & $\begin{array}{r}14735194 \\
204082\end{array}$ & $\begin{array}{r}15103,6 \\
42,7\end{array}$ & $\begin{array}{r}4833.1 \\
0\end{array}$ & $\begin{array}{r}10270,4 \\
42,7\end{array}$ & \\
\hline $\begin{array}{l}\text { Seo I.dos Compos } \\
\text { Sao Roques }\end{array}$ & & 14 & $\begin{array}{r}383607 \\
54283\end{array}$ & $\begin{array}{r}150 \\
36,2\end{array}$ & 0 & $\begin{array}{l}0 \\
0\end{array}$ & $\begin{array}{r}150 \\
36,2\end{array}$ \\
\hline Apucamin & 86 & & 86805 & 22 & 18,9 & 3.1 & \\
\hline Arapongas & 100 & & 57265 & 41,6 & 41,6 & 0 & \\
\hline $\begin{array}{l}\text { Armutia } \\
\text { Campo Molrio }\end{array}$ & 100 & 100 & $\begin{array}{l}31050 \\
61286\end{array}$ & $\begin{array}{l}22,2 \\
30,2\end{array}$ & $\begin{array}{r}0 \\
30.2\end{array}$ & $\begin{array}{r}22,2 \\
0\end{array}$ & \\
\hline & 800 & & & & & & \\
\hline $\begin{array}{l}\text { Comdlio Procópio } \\
\text { Curitiba Rog.Motrop. }\end{array}$ & 100 & 100 & $\begin{array}{r}35486 \\
1410467\end{array}$ & $\begin{array}{r}22.2 \\
399.2\end{array}$ & $\begin{array}{r}0 \\
399,2\end{array}$ & $\begin{array}{r}22,2 \\
0\end{array}$ & \\
\hline Prameioco Boltráo & & 100 & 32159 & 14,4 & 이 & 14,4 & \\
\hline
\end{tabular}




\begin{tabular}{|c|c|c|c|c|c|c|c|}
\hline \multicolumn{8}{|c|}{ 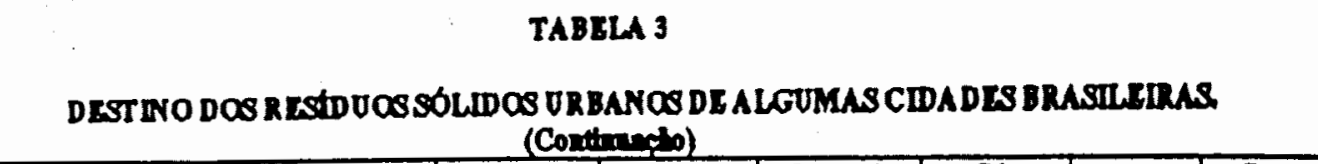 } \\
\hline CIDADE & $\begin{array}{c}\text { Dopas } \\
\text { cin } \\
\text { Aboro }\end{array}$ & $\begin{array}{l}\text { Proceson- } \\
\text { memase } \\
\text { Ontros }\end{array}$ & $\begin{array}{l}\text { Popinglo } \\
\text { Contice }\end{array}$ & $\begin{array}{l}\text { Qunde } \\
\text { Redtes } \\
\text { (ovitin) }\end{array}$ & 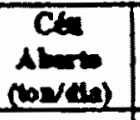 & $\begin{array}{c}\text { Orane } \\
\text { (woves) }\end{array}$ & $\begin{array}{c}\operatorname{sen} \\
\operatorname{lom} \\
(\log / 4)\end{array}$ \\
\hline Guasequeva & 100 & 100 & $\begin{array}{r}120942 \\
20686\end{array}$ & $\begin{array}{l}10.3 \\
10.3\end{array}$ & $\begin{array}{r}40,3 \\
0\end{array}$ & $\begin{array}{r}0 \\
10.3\end{array}$ & \\
\hline $\begin{array}{l}\text { Lontine } \\
\text { Parenague }\end{array}$ & $\begin{array}{l}100 \\
100\end{array}$ & & $\begin{array}{r}321411 \\
90000\end{array}$ & $\begin{array}{r}130,1 \\
13\end{array}$ & $\begin{array}{r}130.1 \\
43\end{array}$ & 0 & . \\
\hline $\begin{array}{l}\text { Panta Grom } \\
\text { Twamico Bate }\end{array}$ & $\begin{array}{l}100 \\
100\end{array}$ & & $\begin{array}{r}236318 \\
12271\end{array}$ & $\begin{array}{l}98.3 \\
21.4\end{array}$ & $\begin{array}{l}98,3 \\
21,4\end{array}$ & 0 & \\
\hline $\begin{array}{l}\text { Toledo } \\
\text { Ummenme }\end{array}$ & 100 & & $\begin{array}{l}10433 \\
97336\end{array}$ & $\begin{array}{l}21,6 \\
54,6\end{array}$ & $\begin{array}{l}21,6 \\
54,6\end{array}$ & $\begin{array}{l}0 \\
0\end{array}$ & \\
\hline $\begin{array}{l}\text { Uniro de Vitoria } \\
\text { Nowo Heantruses }\end{array}$ & & 100 & $\begin{array}{r}99205 \\
164411\end{array}$ & $\begin{array}{l}23,8 \\
89,9\end{array}$ & $\begin{array}{l}0 \\
0\end{array}$ & $\begin{array}{r}23,8 \\
0\end{array}$ & \\
\hline $\begin{array}{l}\text { Peoso Pundo } \\
\text { Palotes }\end{array}$ & & 100 & $\begin{array}{r}99440 \\
308879\end{array}$ & $\begin{array}{r}64 \\
1427\end{array}$ & $\begin{array}{l}0 \\
0\end{array}$ & $\begin{array}{r}0 \\
162,7\end{array}$ & . \\
\hline $\begin{array}{l}\text { Parto Aleges } \\
\text { Rio Orands }\end{array}$ & 100 & & $\begin{array}{r}1263450 \\
236000\end{array}$ & $\begin{array}{l}600,1 \\
104,1\end{array}$ & 104,1 & $\begin{array}{l}0 \\
0\end{array}$ & \\
\hline $\begin{array}{l}\text { Senta Mrie } \\
\text { Sunta Crue do Sul }\end{array}$ & $\begin{array}{l}100 \\
100\end{array}$ & & $\begin{array}{r}168685 \\
63353\end{array}$ & $\begin{array}{r}729 \\
46\end{array}$ & $\begin{array}{r}72,9 \\
46\end{array}$ & o) & \\
\hline $\begin{array}{l}\text { Sento Anovio } \\
\text { Compeco }\end{array}$ & & & $\begin{array}{l}62855 \\
69941\end{array}$ & 60 & 0 & 0 & \\
\hline $\begin{array}{l}\text { Cxicium } \\
\text { Plosinospolis }\end{array}$ & 100 & & $\begin{array}{l}110604 \\
232750\end{array}$ & $\begin{array}{r}80 \\
250\end{array}$ & $\begin{array}{r}0 \\
250\end{array}$ & 0) & \\
\hline $\begin{array}{l}\text { Ixis } \\
\text { Jainvilo }\end{array}$ & & & $\begin{array}{r}80115 \\
329908\end{array}$ & $\begin{array}{c}1200 \\
180.1\end{array}$ & 0) & 이 & \\
\hline $\begin{array}{l}\text { Leoros } \\
\text { Bramais }\end{array}$ & 7 & 93 & $\begin{array}{r}117717 \\
1567709\end{array}$ & $\begin{array}{r}45 \\
10002\end{array}$ & $\begin{array}{r}3,1 \\
400,1\end{array}$ & $\begin{array}{r}41.8 \\
600.1\end{array}$ & \\
\hline $\begin{array}{l}\text { Cunsus } \\
\text { Mecorio }\end{array}$ & 100 & & $\begin{array}{l}450000 \\
501123\end{array}$ & $\begin{array}{l}199,8 \\
2726\end{array}$ & 2726 & 이 & \\
\hline $\begin{array}{l}\text { Inblue } \\
\text { SAlvedor }\end{array}$ & 100 & & $\begin{array}{r}80685 \\
1800000\end{array}$ & $\begin{array}{r}60 \\
2100,6\end{array}$ & 2100.6 & 0 & \\
\hline $\begin{array}{l}\text { Fortalosa } \\
\text { Cecopios Grande }\end{array}$ & & 100 & $\begin{array}{r}1732319 \\
278995\end{array}$ & $\begin{array}{r}1290,6 \\
136,1\end{array}$ & 0) & $\begin{array}{r}0 \\
136.1\end{array}$ & \\
\hline $\begin{array}{l}\text { Torodina } \\
\text { Momarb }\end{array}$ & $\begin{array}{l}100 \\
100\end{array}$ & & $\begin{array}{l}498813 \\
215918\end{array}$ & $\begin{array}{l}980,2 \\
174,9\end{array}$ & $\begin{array}{r}980,2 \\
174\end{array}$ & $\begin{array}{l}0 \\
0\end{array}$ & \\
\hline $\begin{array}{l}\text { Netal } \\
\text { Asecaju }\end{array}$ & 80 & 20 & $\begin{array}{l}547900 \\
387280\end{array}$ & $\begin{array}{r}600 \\
200,2\end{array}$ & $\begin{array}{r}480 \\
0\end{array}$ & $\begin{array}{r}120 \\
0\end{array}$ & \\
\hline Menaus & 96 & 4 & 1537582 & 853.4 & 819,2 & 34,1 & \\
\hline
\end{tabular}

Ponte: PIOUEIREDO (43) 


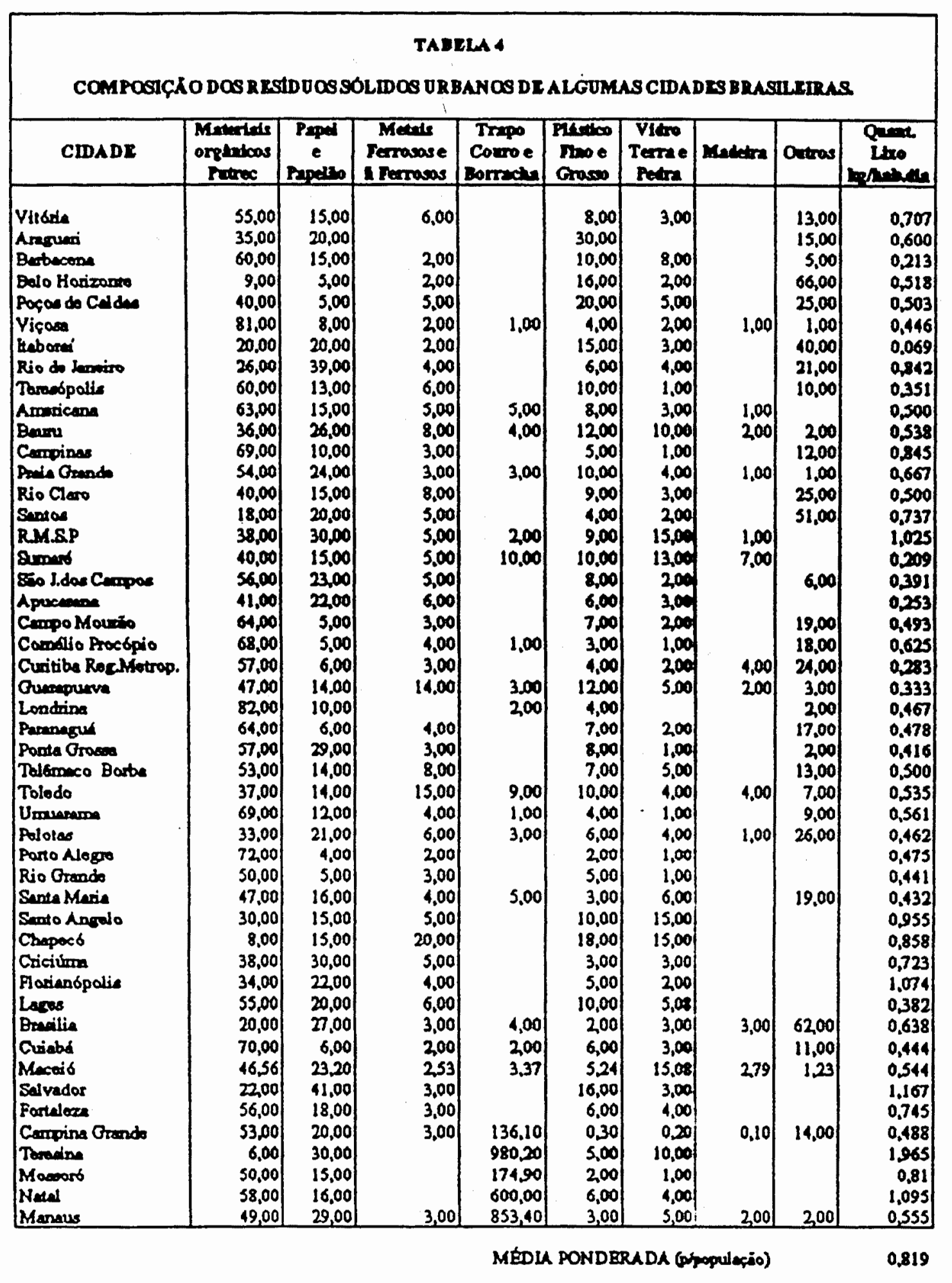

POAT: FIOUEIREDO (43) 


\begin{tabular}{|c|c|c|c|c|c|}
\hline & & TABRI & A 5 & Dornatun: & \\
\hline & & & & ה & NO YAULU. \\
\hline & INTRF & IOR & RMS & & \\
\hline $\begin{array}{c}\text { CLASSE DE } \\
\text { MUNICTPIOS } \\
\text { POR PRODUCAO } \\
\text { DE LXO } \\
\end{array}$ & $\begin{array}{c}\text { NUM.DE } \\
\text { MUNICIPJOS }\end{array}$ & $\begin{array}{l}\text { PRODUCAO } \\
\text { TOTAL } \\
\text { DELIXO } \\
\text { (ton'dis) } \\
\end{array}$ & $\begin{array}{c}\text { NUM.DE } \\
\text { MUNICIPIOS }\end{array}$ & \begin{tabular}{|c|} 
PRODUCAO \\
TOTAL \\
DE LIXO \\
(ton/dia) \\
\end{tabular} & $\begin{array}{l}\text { PRODUÇAO } \\
\text { TOTAL } \\
\text { (ton/diz) }\end{array}$ \\
\hline At $\in 50 \mathrm{ton} / \mathrm{dia}$ & 508 & 2,843 & 18 & 255 & 3,098 \\
\hline 50.100 ton $/ \mathrm{dia}$ & 13 & 881 & 10 & 723 & 1,604 \\
\hline $100-500$ ton/diz & 12 & 1,881 & 7 & 1,813 & 3,694 \\
\hline $\begin{array}{l}\text { Acime de } \\
500 \text { ton/dia }\end{array}$ & 1 & 516 & 3 & 9,216 & 9,732 \\
\hline TOTAL & 534 & 6,121 & 38 & 12,007 & 18,128 \\
\hline
\end{tabular}

Fonte: CETESB/90 (03) 


\begin{tabular}{|c|c|c|c|c|c|c|}
\hline \multicolumn{7}{|c|}{$\begin{array}{l}\text { TABELA } 6 \\
\text { RO FINAL DE RRSTUUOS SOLLDOS URBANOS. }\end{array}$} \\
\hline \multirow{2}{*}{$\begin{array}{c}\text { TIPOS DE DESINACAO } \\
\text { FINAL }\end{array}$} & \multicolumn{2}{|c|}{ INTKRIOR } & \multicolumn{2}{|c|}{ RMSP } & \multicolumn{2}{|c|}{ TOTAL } \\
\hline & $\begin{array}{l}\text { NUM. DB } \\
\text { UNIDADES }\end{array}$ & $\begin{array}{l}\text { QUANT. } \\
\text { DELIXO } \\
\text { (tondia) }\end{array}$ & $\begin{array}{l}\text { NUM. DB } \\
\text { UNIDADBS }\end{array}$ & $\begin{array}{l}\text { QUANT. } \\
\text { DB LIXO } \\
\text { (tooldia) }\end{array}$ & $\begin{array}{l}\text { NUM.DB } \\
\text { UNIDADBS }\end{array}$ & $\begin{array}{l}\text { QUANT. } \\
\text { DB LIXO } \\
\text { (tod dia) }\end{array}$ \\
\hline Lixzos & 491 & 3953 & 29 & 2081 & 520 & 6034 \\
\hline $\begin{array}{l}\text { Aterros Adequadoce ou } \\
\text { Controlados }\end{array}$ & 41 & 1513 & 14 & 7576 & 55 & 9089 \\
\hline $\begin{array}{l}\text { Usinas } \\
\text { do } \\
\text { Compos- } \\
\text { tagem Oparafio } \\
\text { Nzo Operando }\end{array}$ & $\begin{array}{l}8 \\
8\end{array}$ & $\begin{array}{l}655 \\
880 *\end{array}$ & $\begin{array}{l}3 \\
1\end{array}$ & $\begin{array}{l}1950 \\
100 *\end{array}$ & $\begin{array}{l}11 \\
9\end{array}$ & $\begin{array}{l}2605 \\
980\end{array}$ \\
\hline lnoinoradores & 0 & 0 & 2 & 400 & 2 & 400 \\
\hline TOTAL & $54 \%$ & 6121 & $49: *$ & 12607 & $597 *$ & 18120 \\
\hline
\end{tabular}

OBS: * Quantidade potencial nino computade ma totalizagia

** Total de unidade diferente do total de muniópioe derldo vartos tpoe de deadinagio por mundaplo ou encaminhameato do lixo para out ros municípios

Fonte: CETRSB/90 (03) 


\begin{tabular}{|c|c|c|c|c|c|}
\hline \multicolumn{6}{|c|}{$\begin{array}{l}\text { AVALIACAO DAS CONDIÇORS DE INSTALAÇORS PARA DRSTINACAXO FINAL } \\
\text { DOS RRSTDUOS SOLIDOS URBANOS. }\end{array}$} \\
\hline & INTER & $\mathbf{O R}$ & RMSP & & \\
\hline $\begin{array}{l}\text { CONDICCORS DA } \\
\text { DESTINACAO FINAL }\end{array}$ & $\begin{array}{c}\text { NUM.DB } \\
\text { MUNICIPIOS }\end{array}$ & $\begin{array}{l}\text { QUANT. } \\
\text { DE LIXO } \\
\text { (ton/dis) }\end{array}$ & $\begin{array}{c}\text { NUM.DB } \\
\text { MUNICIPIOS }\end{array}$ & \begin{tabular}{|l|} 
QUANT. \\
DE LIXO \\
(too/dia) \\
\end{tabular} & $\begin{array}{l}\text { QUANT. } \\
\text { TOTAL } \\
\text { (tan/dia) }\end{array}$ \\
\hline Condiços Adequades & 8 & 318 & 0 & 0 & 318 \\
\hline Condipöos Controladas & 35 & 1777 & 11 & 9926 & 11703 \\
\hline Condifros Inadequades & 491 & 4026 & 24 & 2081 & 6107 \\
\hline TOTAL & 534 & 6121 & 38 & $12 \leadsto 7$ & 18128 \\
\hline
\end{tabular}

Fontes CRTRSB/90 (03) 
III.5. E COMO E A SITUACAO MUNDIAL DOS RESIDUOS ?

o problema do excesso de resíduos e as formas mais adequadas de tratamento. tem levado pesquisadores e governos a estudos capazes de indicar caminhos e diretrizes a serem seguidos. Um programa de cooperação técnica entre o Governo do México e a Organização das Nações Unidas para o Desenvolvimento Industrial-ONUDI(UNIDO) levantou informaçōes em países desenvolvidos e em desenvolvimento com relação à esse problema.

Constatou-se que en todos os países industrializados. o nivel de bem estar social estimula seus habitantes a gerar volumes de resíduos sólidos. que sãó duas ou très vezes maiores que os correspondentes em paises em desenvolvimento. Isto tem originado uma situação considerada crítica em diversos paises. principalmente em alguns lugares dos Estados Unidos $(26)$.

Cada dia é maior a preocupação existente com a saturacão dos aterros sanitários. com a contaminação do lencol freático e com o impacto ambiental geral resultante do consumo desmedido de recursos naturais. 
Nos paises em desenvolvimento o problema se amplia, pois, enquanto uma parcela da população apresenta níveis ae consumo equivalentes aos dos países industrializados, gerando os mesmos problemas, parcela substancial da população está marginalizada, com elevados niveis de subnutrição, ao mesmo tempo que grandes quantidades de alimento são desperdiçadas por manipulacāo. acondicionamento. transporte e armazenamento inadequados. Alguns destes países estão ainda apenas na fase de regulamentacào da administracão dos problemas de limpeza urbana. visando exclusivamente combater os problemas de saúde pública.caso do Peru. Guatemala, Nicarágua e São José da Costa Rica(26).

Esse estudo demonstrou ainda que alguns países em desenvolvimento, caso do Brasil e da India,se destacam por apresentarem uma maior preocupação ambiental envolvendo essa questão. buscando soluções de nivel semelhante às dos países desenvolvidos. 
III.6. QUAL SERIA A SOLUCAO ?

Nos anos 70 as políticas de controle de resíduos sólidos buscavam estabelecer normas referentes à forma mais adequada de coleta e, principalmente, de disposição do material descartado. Nos anos 80 enfatizou-se as formas de pré-tratamento e a destruição desse material. Atualmente a tendência nos paises industrializados é o estabelecimento de critérios e incentivos que permitam a implantação de programas de prevenção e redução na fonte geradora, assim como programas de recuperação dos recursos dos resíduos(reutilização direta e reutilizacào indireta através do uso da matéria prima. também chamada atualmente de reciclagem de resíduos, com o fim específico de diminuicāo da quantidade a ser disposta(48,70).

A política de Minimização de Resíduos (Waste Minimization) foi introduzida nos EUA a partir de uma diretriz do Congresso Americano em 1984. criando o "Hazardous and Solid Wastes Amendments to the Resource Conservation and Recovery Acts (RCRA)" (37).

Embora seiam focalizados prioritariamente os residuos tóxicos industriais. considera-se que todos os potenciais poluentes do ar, água e solo devem ser 
considerados nesses programas(37. 38. 46). Minimizar resíduos é basicamente buscar formas de reducāo de resíduos na fonte e de reciclagem (figura 1 ).

A meta considerada é sempre de diminuicào da geração dos resíduos a serem dispostos ou tratados, priorizando inicialmente as acōes de redução de volume e de diminuicāo de toxicidade do material a ser descartado, e posteriormente encaminhamento à reciclagem ou recuperação dos resíduos que não puderam ter a sua geração evitada.

Além da proteção do ambiente e da saude do trabalhador, esse programa foi desenvolvido visando a diminuição dos custos de tratamento e/ou disposição dos resíduos industriais e tóxicos. e o melhor aproveitamento da matéria prima.

A agência americana de protecão ambiental (Environmental Protection Agency-EPA) tem, nos últimos anos. desenvolvido uma série de acōes de estímulo apoio e regulamentacào das atividades de minimizacāo de resíduos.além da producão de material de apoio adequado( 38 ).

Em junho de 1987. em encontro promovido pela "Tufts University Center for Management" e a EPA, as 24 maiores corporacòes americanas relataram suas atividades de minimizacảo de resíduos, entre elas as bem sucedidas experiências da Dupont, Dow e $3 M(37)$. 
A mesma postura é adotada, há algum tempo por outros países do primeiro mundo, como é o caso da Alemanha. onde a "Federal Environmental Agency", considera a prevençāo e a reciclagem de resíduos como pré-condição para o licenciamento de plantas industriais(49). 
fig.l

\section{MINIMIZAÇÃO DE RESÍDUOS}

Redução/Reutilização na Fonte

Reciclagem

ATITUDES AMBIENTALMENTE ADEQUADAS

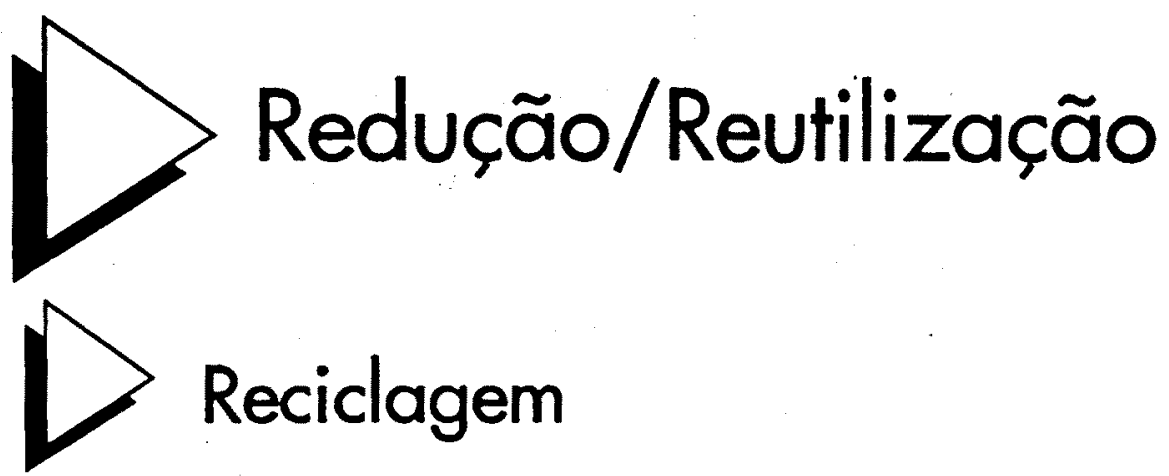

baseado em: EPA/USA, 89 (37). 
III.7. E A MINIMIZAÇAO DE RESIDUOS SOLIDOS URBANOS, E POSSIVEL ?

Com relação aos resíduos sólidos urbanos o estabelecimento de programas de minimização é solução de maior complexidade. pois nosso modelo de consumo atual está baseado no uso crescente de bens descartáveis e no desperdício de recursos naturais.

E se nos programas de minimização de resíduos industriais, vantagens econômicas claras são chamarizes atraentes para o engajamento dos setores industriais. o oposto prevalece quando buscamos miniaizar os residuos sólidos urbanos produzidos nas atividades cotidianas de uma cidade. Por ser um problema multifacetado.complexo. exige para ser minimizado. novas posturas dos vários setores da sociedade. assim como mudanças comportamentais de toda a populacáo. procedimentos estes que exigem investimentos em educacao. invest imentos normalmente nào considerados essenciais pelos responsáveis pela resolucão deste tipo de problema. 
De qualquer forma uma série de açóes a

nivel mundial. principalmente nos paises desenvolvidos, busca a diminuicão da geracāo na fonte e a recuperação dos recursos ou reciclagem dos resíduos sólidos urbanos.

0 que fazer com os residuos parece ser no momento um dos principais problemas ambientais dos Estados Unidos,se não for o wais grave, una vez que a quantidade de resíduos gerados per capita é aproximadamente o dobro do japonês e europeu e está na casa de $1 / 2$ tonelada por ano(19). Outros autores chegan a colocar que un anericano médio produz cerca de 2.5 quilos de resíduos diariamente(45). Embora o problema de espaco nào seja tão grave quanto o encontrado no Japão, áreas adequadas, próximas aos grandes centros, estão se tornando escassas e o custo da disposiçäo está se tornando extremanente alto. podendo chegar a 100 dólares ou mais por tonelada (36).

Há aproximadamente 6000 aterros sendo legalmente operados nos EUA. que absorvem $80 \%$ dos residuos sólidos produzidos. sendo $10 \%$ incinerados e $10 \%$ reciclados $(36.45)$.

- que fazer com tanto resíduos sólidos

urbanos produzidos gerou uma crise sen precedentes que. entre outras acỏes tem levado vários seg̣mentos da populacão. grupos organizados e liderancas politicas. a questionar o padrão de consumo e desperdicio. que iá foi inclusive exporsado para o mundo $(18 \cdot 19.45)$. 
A "Environmental Protection Agency-EPA" lancou como metas a redução na fonte de $25 \%$, un incremento de reciclagem de $25 \%$ e a redução da incineracão de $25 \%(36)$.

Do ponto de vista da Comunidade Européia a linha mestra é reduzir o problema origem. (40) A neta deve ser a redução quantitativa dos residuos e a welhora qualitativa destes. Fica clara a necessidade de uma nova cultura onde os produtos sejam produzidos tendo en vista.alén do seu uso, a sua reciclagem ou recuperaçāo energética(44).As legislaçōes holandesa. francesa, inglesa, italiana, portuguesa e a da comunidade européia propöen tanto a reciclagen dos materiais quanto a recuperação de energia. $(40)$.

\section{A Organização de cooperação e} Desenvolvimento Econômico-OCDE. salienta a importância do estudo do ciclo de vida integrado de produtos. isto é. devem ser considerados os impactos ao ambiente, desde a obtenção da matéria prima até a sua transformacão em rejeito. Sempre considerando que todas essas frentes devem ser atacadas. uma vez que resíduos são gerados na extração da matéria prima.durante o processo de producāo e após findar o tempo de vida útil de um produto e não apenas no seu descarte final(44).

Salienta-se a necessidade da prevenção da geracāo de resíduos.e a necessidade de promocão de tecnologias mais limpas. Onde um novo modelo de producão gere menos residuos e. ao mesmo tempo. produtos melhores. Implantar 
tecnologia mais limpa significa analisar a atéria prima, substituí-la por outra se necessário.analisando etapa por etapa, modificando o processo produtivo e agindo quando necessário lcontrolando perdas. recuperando resíduos dentro do próprio ciclo produtivo. reutilizando a matéria-prima, por eles chamada de matéria segunda) $(44)$.

Seguindo essa polftica vários países legistam e se posicionam. Por exemplo, em 1984 a Dinamarca baniu o uso de embalagens "one-way" para cerve.jas. EM 1989 foi criada na Itália uma taxa para as indústrias produtoras de embalagens, para o financiamento de operaçöes de reciclagem. Na Holanda foi assinado. entre a indústria de embalagens e 0 governo, un acordo que envolve o fechamento dos aterros no ano 2000, reciclagem de aproximadamente $60 \%$ das embalagens, incineracão de $40 \%$ e reducāo das embalagens en $10 \%$ para valores de 1986 . São metas audaciosas se levarmos em consideração que em 1988 a reciclagem representava $35 \%$ e $55 \%$ dos resíduos eram encaninhados aos aterros sanitários(40.44).Na Franca também toi feito um acordo no inicio de 1992 para reciclagem ou incineracào com recuperacāo de energia para $50 \%$ do total de embalagens até 1994 e de $\$ \$ 0.6$ até o ano $2000(40)$. 
Entretanto, é na Alemanha que a legislacão se mostra mais rigida .A chanada "Lei Topfer" estabelece que na produção de embalagens deve-se usar a quantidade de material estritamente necessária para proteger e vender o produto. e só permite embalagens sem retorno se forem produzidas com material reciclável, na inexistência de condiçōes de uso de embalazens reutilizáveis $(29,30,40,41)$.

Abrange todos os tipos de embalagens, que saio classificadas en três grupos: embalagens de transporte.embalagens de venda e embalagens adicionais/onde se incluem as embalagens "multipacks", acessórios promocionais,etc). A partir dessa lei os produtores e vendedores ficaran obrigados a aceitar as embalagens de volta.Foi estipulado que a partir de $1 / 12 / 91$ os consumidores poderian deixar todas as embalagens de transporte nos pontos de venda.A partir de 1/04/92 as embalagens adicionais. e a partir de 1/01/93 todas as embalagens usadas poderian ser deixadas nos pontos de aquisição dos produtos.

Os comerciantes ficaram obrigados a instalar "coletores" para o recolhimento destas embalagens. e só se isentam se existir na sua zona um circuito de recolhimento destes. O sistema público deixou de aceitar resíduos de embalagens: as embalagens recolhidas pelos vareiistas sã. coletadas por sistemas alternativos pagos pelos próprios operadores econômicos. 
A embalarem reutilizável é proterida e favorecida e foram determinadas quotas de mercado:76x em 1996. 98 en 1998 e $81 \%$ no ano 2000. Foran fixados tambén objetivos quantitativos quanto à reciclagen destes materiais:50\% até 1 de janeiro de 1993.80\% até 1 de julho de 1993. $80 \%$ até 1995 e $90 \%$ até o ano 2000 .

Nestas metas não se incluiu incineração, que foi omitida na lei alemā(29,30).0 que chama a atenção é que nenhuma verba pública é gasta, todo o investimento necessário para a coleta e posterior reciclagen vem dos setores envolvidos comercialmente com a questäo.

Un primeiro esboco de diretiva para a Comunidade Européia, orientando a questão das embalagens e o weio ambiente. foi proposta em maio de 1991. Após discussões un segundo esboco foi proposto em setembro de 1991: depois un terceiro e um quarto, que foi encaminhada para o Parlamento Europeu para discussảo(40.41).

Diferentemente da Lei Topfer alemã ela inclui recuperacào de energia através de"incineração limpa".Com relacão à meta proposta. de $90 \%$ de recuperação até o ano 2000. ambas equivalem mas a lei alemà é mais rígida. uma vez que como nesta a incineracāo é proibida. esse total deve ser atingido com a reciclagem real dos materiais. descartando os processos que apenas recuperam a energia. desperdicando matéria prima. Já na Comunidade Européia. como a incineração é permitida. a meta 
para o ano 2000 de $90 \%$ deve ser cumprida. com $60 \%$ de reciclaxem e sư de incineracão.

Ea compensacāo a Diretiva obriga os estados membros a implementar uma orientacão comum, de acordo com uma política única com relacão ao gerenciamento dos resíduos.tais como:

Garantir que no prazo máximo de 5 anos após a Diretiva entrar em vigor, a concentração de metais pesados $e$ outras substâncias tóxicas nos materiais de embalagem não exceda o limite de concentração de 100 ppm(600 após 2 anos, 300 ppm após 3 anos e 100 ppa após 5 anos).

Assegurar no gerenciamento dos residuos de embalagens,a divisào de responsabilidades entre todos os setores econômicos envolvidos na geracão destes.

Prover todas as informaçōes aos consumidores sobre as vantagens ambientais das embalagens retornaveis e reciclaveis e com relacão à identificacāo dos materiais constituintes e a retornabilidade ou reciclabilidade destes.

Estimular os consumidores a participar ativamente dos sistemas de coleta seletiva destes materiais (40). 
1.DTtERCERTE

MODEGRADÁVE

Não polvi a ógua

2. ROUA RECICLAOA

Esgoto tratado virou digu

para obastecimento,

corre pelos torneiros.

chuveiros etc.

Recebe apenas restos de

comido

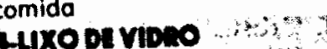

ravco

Recebe garrafas poro

recilar

Recebe garroias para

recilar

Luxo de vidno

MAREOM

Recebe garrafos pora

recilar

Hxo de pluHase

LAMMINAS

Recebe apenos pilhos 8

baterias

o-lixo de LATAS

Recebe latas de aluminio

9-madara

meflonestada

A lareira nõo queima

florestas novas

Células convertem luz em

Células conver
eletricidade

11.Calon do sor

Coletores captam calor do

sol

2-gas natural

Biodigestor produz gós

encanad

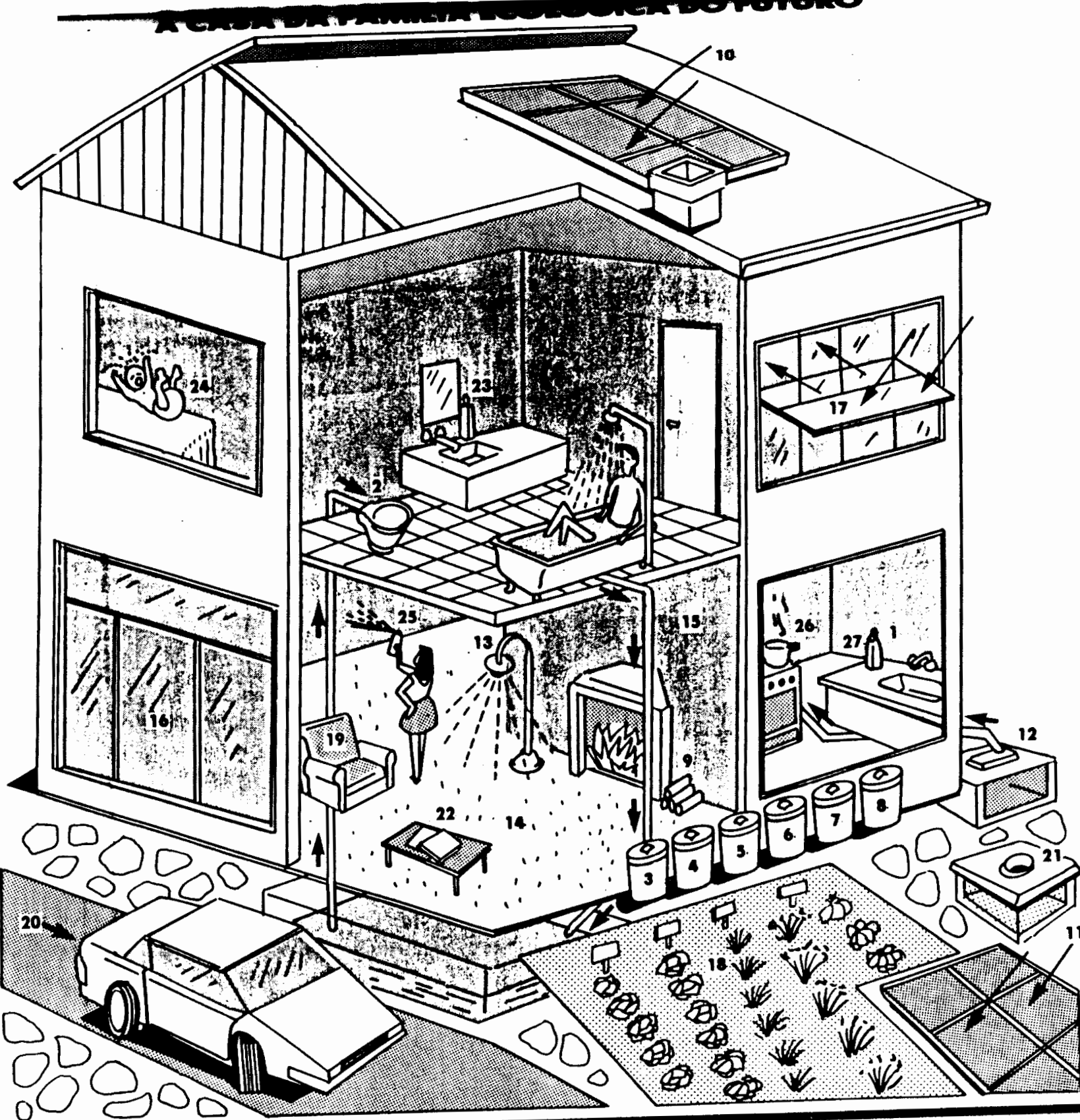

12unzos ae oracho

Novas lámpodas gastom

menos energia

ILCakmstrimaruan

15-11NTA "VReror"

De qualquer cor, usa bgua

no lugar de solventes

lluminacon naturol

17.2Atrinks or Luz

Espelhos regulam o

luminaçóo

iswoptanktuzal

Uso fertilizantes organicos

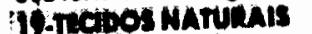

fos sem libros sintéticos

a cario com pritho

Catalisador diminui

poluiço por $\mathrm{CO} 2$

policaixas onoAnicas

21-Caixas OnvanICa

Produzem odubo com

restos orgánicos dado

Aproveila sobras e aparas

de popel nirtios

MaTURAas

Usam openas produlos

naturais não testados em

matialoa de pano

Descarta os fraldas

descartóveis

Não utiliza o gás que

destrói a comada de ozónio

26-COMibA ONo ANICA

Cultivado sem agrotóxicos

Dissolvem-se naturalmente 
III.8. E A COLETA SELETIVA NO BRASIL ?

Em 19 de novembro de 1990 o jornal "Folha de São Paulo apresentava como "a casa ecológica do futuro", aquela onde. entre outras coisas. havia o uso de "seis latas de lixo" para coleta dos residuos potencialnente recicláveis (3 latas para vidro branco, verde e âmbar: una para pilhas e lâminas de barbear: una para latas de alunínio e una para orgânicos).

Davam-se os exemplos da Alemanha e da Suica. iustificando-se a importância da reciclagem dos materiais iá utilizados. do aproveitamento dos restos orgânicos para adubo. além da separacào dos residuos tóxicos contendo metais pesados.

Interessante salientar que esta reportagem sequer citava as experiencias de coleta seletiva dos residuos sólidos domésticos que estavam acontecendo no Brasil ia naquela época: a pioneira experiência do Bairro de São Francisco em Niterói. iniciada em abril de 1985. e coordenada pelo introdutor da coleta seletiva no Brasil, Emílio $M$. Eigenheer (65): a coleta seletiva de Sāo Sebastião no Litoral 
Norte do Estado de Sào Paulo. coordenada e realizada pelas pioneiras ambientalistas Patricia R. Blauth e Georgeta de Oliveira Gonçalves, que em 13 de abril 1989 iniciaram o 10 pro.jeto brasileiro, via prefeitura municipal, que serviu de modelo para outros municípios $(35,59)$.

Não foram citadas nem as experiências já iniciadas en capitais ou cidades de naior porte, como é o caso da cidade de São Paulo (dezembro de 1989). São José dos Campos e Florianopolis (inicio de 1990). Santos(maio de 1990). Porto Alegre (Junho de 1990), tendo inclusive Curitiba, que iniciou seu trabalho en 1989, recebido premio da ONU por este projeto en setembro de $1990(58,62)$.

\section{Interessante constatar que ambientalis-}

tas de renome na área ambiental nacional. quando entrevistados a respeito do problema "resíduos domésticos e ambiente" se posicionaram colocando a necessidade de se descartar os residuos no local adequado. isto é. em""lixeiras". e de não se utilizar produtos descartáveis. Colocaram ainda as suas experièncias em recolher o lixo quando de passeios a áreas naturais. mas ressaltaram que a principal atividade conservacionista do brasileiro deveria ser a economia de energia e de áqua. Foi citado. que inclusive atos públicos em apoio a accies ambientais (ex: ato pela despoluicão do Rio Tietê). terminaram com chào completamente forrado de lixo. o que deixava patente o descompasso entre o discurso e a prática.l"Folha de São Paulo.19 de novembro de 1990"). 
Sem diminuir a importância de programas de conservacão de água e de energia, e da necessidade básica de se jogar os resíduos em coletores adequados.chama-nos a atenção quảo pouca importância os projetos de coleta seletiva pareciam ter nesta época, a ponto de não serem sequer citados por pessoas afetas à área ambiental e com reconhecido trabalho realizado em outros setores desta área.

Entretanto, percebemos nessa área un dinamismo e uma capacidade de mudança e de avanço dignos de atençāo. e de estudo mais aprofundado. Em 7 de maio de 1992.pesquisa realizada pelo IBOPE-Instituto Nacional de Opiniāo Pública e Estatística, e publicada no "Jornal da Tarde".mostrou que $59 x$ da populaçäo se mostrava disposta a separar seus resíduos para a reciclagem.

Apesar da grande divulgação da Conferência das Nacóes Unidas para o Ambiente e Desenvolvimento/ECO/9? pela mídia. poder ter colaborado para esse alto indice de apoio. acreditamos que as experiências de coleta seletiva de resíduos urbanos estudadas neste trabalho. conseguiram em pouco tempo. um retorno. em alguns casos surpreendente. no que concerne a mudanças de comportamento e a conscientizacao de parcelas da populacão. nảo preocupadas com a questao ambiental até entàc. 
Deixaremos entretanto essa discussāo para mais tarde. Entocaremos nesse momento. a atual situação dos processos e do mercado de recicláveis no Brasil. uma vez que qualquer programa ou projeto de coleta seletiva deve levar en conta o escoamento e o aproveitamento adequado dos materiais coletados. que funcionam como atéria prima secundária. 
III.9. E ENTAXO, COMO ANDA A RECICLAGEM NO BRASIL ?

III.9.a. O PAPEL

A reciclagen de papéis nāo é atividade nova no Brasil: desde os primbrdios da indústria papeleira.pequenas empresas aproveitavam os recortes e sobras de papéis importados da Europa, para fazer novos papéis. A partir da segunda guerra mundial, tornou-se comun nos grandes centros a figura dos carrinheiros, normalmente imigrantes,que exercian essa coleta cono atividade de subsistência(68).

Aos poucos o setor foi evoluindo tecnologicamente e comercialmente, e hoje existen verdadeiras redes de coleta e um sistema complexo de comercializacōes envolvendo:

- o consumidor do papel: é a pessoa que descarta o papel dando-o ou vendendo-o diretamente ou através de coleta seletiva porta-a-porta ou postos de recolhimento ou entrega voluntária:

- o catador: é quem recolhe o material.normalmente em pequena quant idade. concent rando-o em algum ponto:

- o sucateiro: normalmente é o proprietário de uma área. onde é acumulado o material coletado pelos catadores:

- o depósito:pequenas empresas com prensas para enfardar. e normalmente com caminhào próprio para coleta nos sucateiros:

- o aparista: é o que compra o material enfardado nos depósitos. revendendo-o às indústrias papeleiras. 
Dependendo da quantidade e das condicōes do papel.este pode ser vendido diretamente a depósito ou aparista, alcancando melhor preco.E o caso de estabelecimentos comerciais.bancos.reparticōes públicas.médias e grandes empresas, que chegam algumas vezes até a vender diretamente à indústria papeleira(08).

Dependendo do tipo de comprador e da presenca de impurezas, impressos e umidade, as aparas alcançam um preco médio variando de US\$0.15 a US\$0.08/ $\mathrm{Kg}(05)$.

Em 1977, atraves de un trabalho conjunto entre a Associacão Nacional dos Fabricantes de Papel e Celulose (ANFPC). o Instituto de Pesquisas Tecnológicas(IPT) e a Associacão Nacional dos Aparistas (ANAP), foram definidas 22 categorias de aparas que são chamadas aparas pré-consumo, no caso de aparas gráficas ou papéis nāo utilizados,ou aparas pósconsumo. no caso de residuos de papéis iá utilizados pela populacão. Estas aparas são classificadas de acordo com a qualidade do papel. grau de impurezas e de materiais proibitivos. isto é. materiais como plásticos,papel carbonometais ou outros.que inviabilizam o processo de reciclagem(08).

$$
\mathrm{Na} \text { indústria papeleira as aparas iá }
$$
selecionadas para a producảo de um determinado tipo de papel.sào desagregadas mecânicamente em meio aquoso. A massa do papel é depurada e refinada até que seja atingido o nível de limpeza 
deseiado. com a eliminacao de impurezas como plástico. metais e tintas. Adicionam-se aditivos, de acordo com o tipo de papel a ser produzido. e em sequida.já na máquina. a massa é depositada numa tela. formando uma folha de papel que é submetida a desaguamento.prensagem e secagem(ver figura 2: o ciclo do papell).

A utilizaçāo de aparas em substituicão a pasta mecânica de celulose apresenta vantagens con relação a ut ilizacäo de recursos naturais e energéticos. Na confecção de papel reciclado uma tonelada de aparas corresponde a dois metros cúbicos de madeira no caso de substituição da pasta mecânica e quatro metros cúbicos na substituicão da pasta química; o que equivale ao rendimento lenhoso de uma área plantada de 100 a 350 metros quadrados $(08)$.

A economia de energia varia com relacáo ao tipo de papel produzido. Dependendo do tipo de pasta utilizada temos para papéis de imprimir e escrever uma economia de $50 \%$. papel iornal de 78\%. papel capa de 35 a $50 \%$ e papel miolo de $65 \% 1081$. 


\section{CICLO DO PAPEL}

Papel Reccclado ou Misto: Embalagens, CADERNID, ...

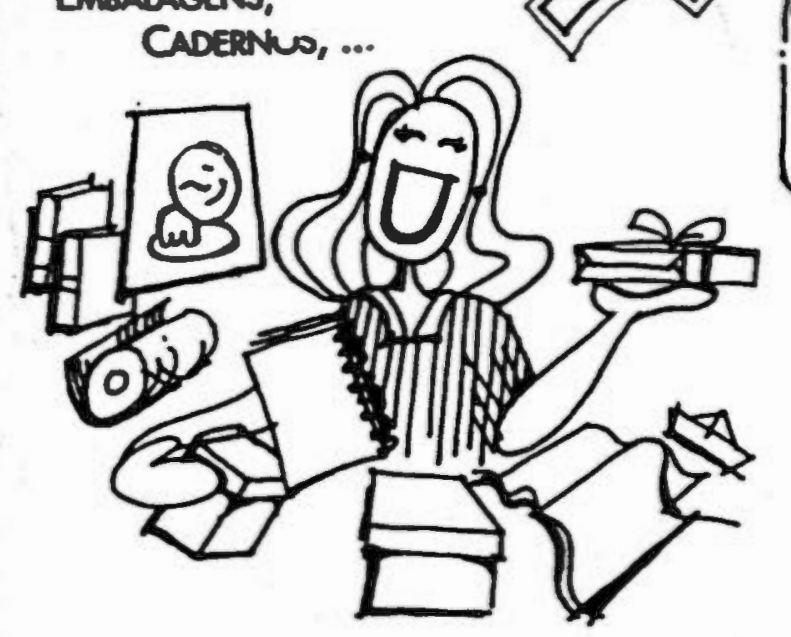

POPULAÇÃO
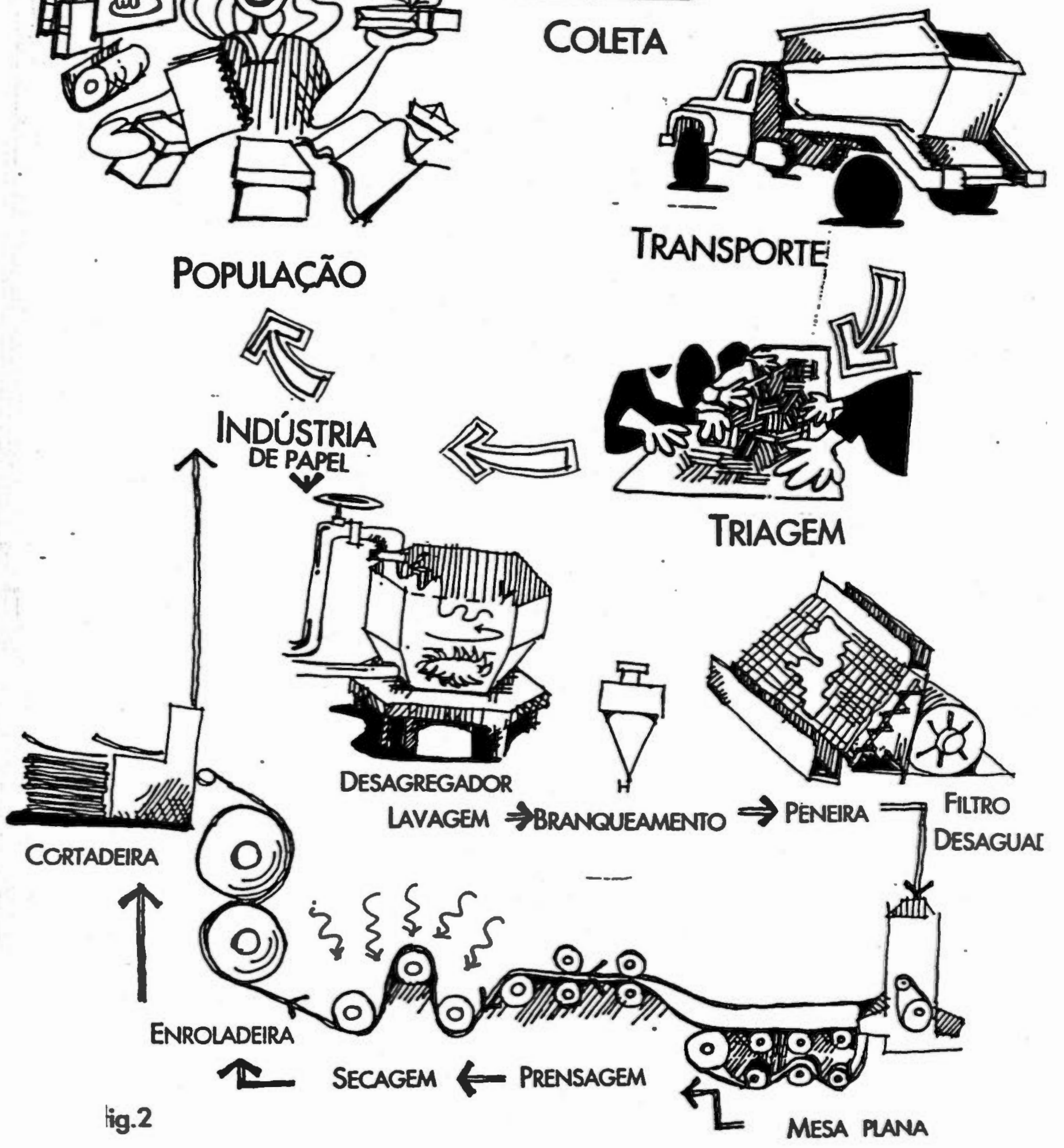

TRANSPORTE 
III.9.b. O VIDRO

o vidro é o resultado da fusāo de diversas matérias primas, que depois de um resfriamento lento e contínuo se transformam em un material duro, transparente, homogêneo. estável, amorfo e isotropo lque possui propriedades idênticas em todas as direçōes). o vidro para embalagens 6 constituído a partir de três elementos básicos: sflica, sódio e calciolvidro sillico-sodo-calcico)(09).

A sillica provém da areia e é o elemento tormador do vidro. tendo una temperatura de fusão muito elevada ( 1800 C 1 . O sódio lobtido da barrilha ou da lixívia de sodal é adicionado para diminuir a temperátura de fusão $(1500$ a 1600 ci. O cálcio é o elemento estabilizador que confere resıstència e maleabilidade.

Outras matérias primas melhoram a qualidade do vidro: dolomita. fornece magnésio que aumenta a resistencia mecânica: feldspato. fornece alumina que torna o vidro mass brilhante e durável: sulfato de sódio. aiuda a refinar o vidro fundido. e colorantes como o ferro. enxofre. cobalto e manganês(09). 
Todo vidro depois de utilizado e descartado pode ser reciclado, tendo un aproveitamento de $100 \% 11$ $\mathrm{Kg}$ de cacos produz $1 \mathrm{~kg}$ de vidro novol. O vidro reciclável pode ser produto de refugo de produção das vidrarias e envasadores, ou material resultante de coleta de catadores e sucateiros, coleta seletiva de resíduos urbanos ou descarte espontâneo em coletores especif icos 109.391 .

No processo de reciclagem do vidro as embalagens descartadas ou os refugos de producão são coletados e tratados.No tratamento realiza-se a eliminação dos contaminantes,como pedras, concreto, louças, terra, cápsulas de chumbo.tampinhas,etc. En seguida o vidro e triturado e lavado.Quando o vidro é triturado no próprio local de coleta ou armazenamento. a lavagen e a limpeza são realizadas após o encaminhamento à indústria vidreira(09).

$\mathrm{Na}$ indústria vidreira os cacos são misturados as materias primas(figura 3: o ciclo do vidrol. o vidro tundido conserva todas as suas propriedades físicas e quimicas. e pode ser transformado indefinidamente em novos produtos sem que haja perda sensivel da matéria vidro. Pode-se utilizar de 30 a $80 \%$ de cacos na produção de novos vidros e quanto maior a quantidade. maior a economia de energia lestes tundem-se à $1200 \mathrm{Cl} .13910 \mathrm{~s}$ cacos substituem as matérias primas 
virgens. evitando a extracào destes recursos não renováveis. e diminuindo a quantidade de resíduos que serian dispostos ea aterros ou lixōes.

A Associação Técnica Brasileira das Indústrias Autonáticas de Vidro(atual ABIVIDRO ex ATBIAV) mantém programas de apoio coleta diferenciada e reciclagem de vidro Ivia implantacāo de coletores de entrega voluntária ou parcerias com prefeituras municipais e/ou entidades assistencialistas) em várias cidades brasileiras. Esses programas tiveram inicio en 1986 em Sảo José do Rio Preto.no estado de Sāo Paulo e, atualmente existem em 24 cidades brasileiras, incluindo Porto Alegre. Recife. Santios. São José dos Campos. São Sebastião, entre outras $(29.40)$.

Nessas cidades a população descarta suas embalagens de vidro separadamente. nos já citados serviços de coleta seletiva domiciliar. ou depositando nos coletores.chamados nos programas de papa-vidros. colocados em pontos de grande circulacáo.

Com esses programas permanentes a intustria vidreira coletou em 1992 cerca de 8000 toneladas de vidros descartados. Entretando. o maior volume de coleta de vidros ainda é obtido a partir da mào de obra informal de catadores e sucateıros. que somados ao refugo e as quebras das linhas de envasamento atingem cerca de 270000 toneladas anuais.de acordo com dados da indústria vidreiral29.301. 
Alguns vidros náo podem ser reciclados ou pelo menos nào podem ser reciclados junto com a maior parte dos vidros descartados pelos consumidores. normalmente composta de embalagens. Existem diferencas que. se nāo controladas, influencian na qualidade final dos produtos fabricados com cacos de origens diversas(tabela 8 ). 
CICLO DO VIDRO

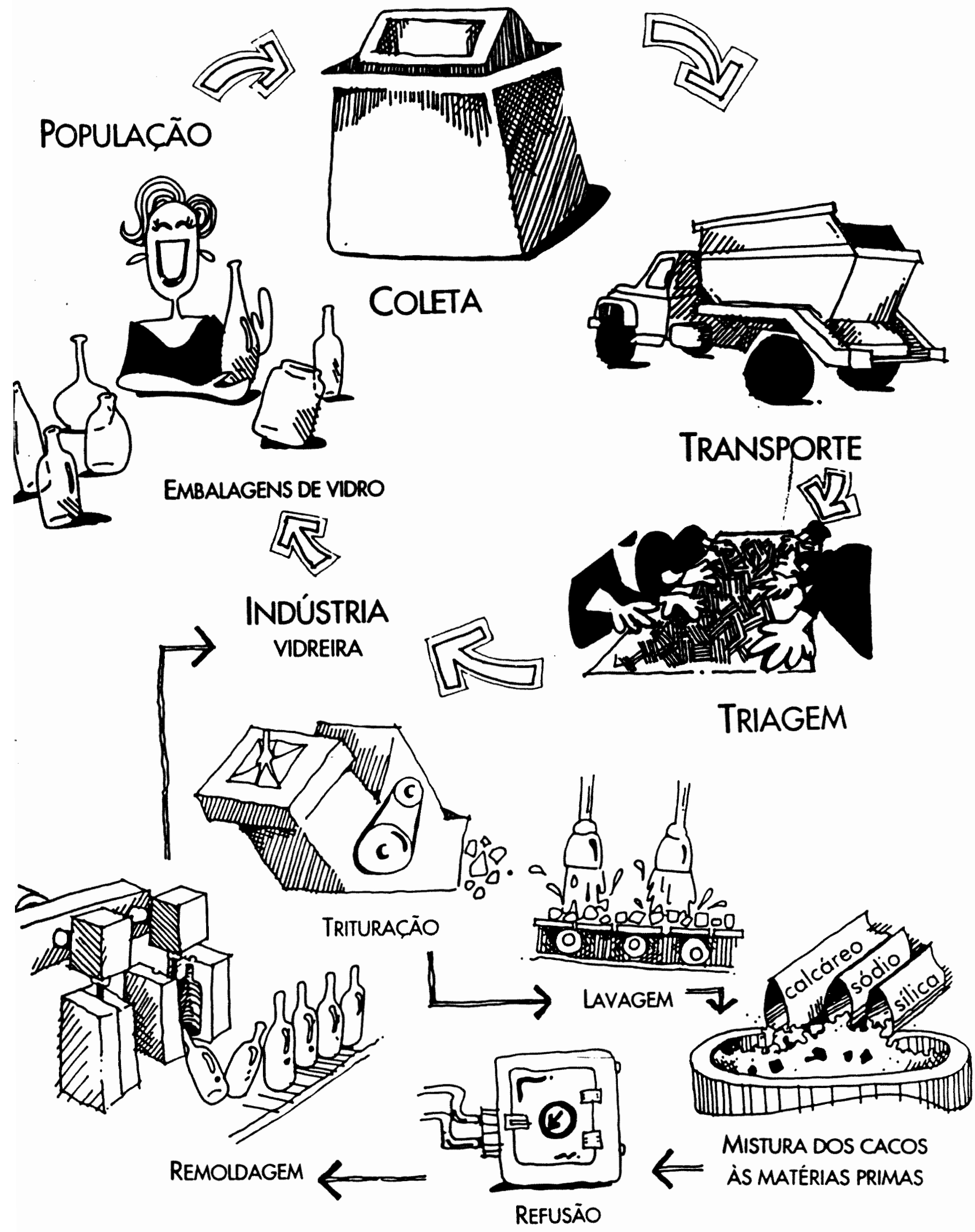

fig. 3 


\begin{tabular}{|c|c|}
\hline \multicolumn{2}{|c|}{ VIDROS NXO ACUTOS PARA RBCICLAGRM } \\
\hline TIPO & CaUza \\
\hline Vidro PIaso & 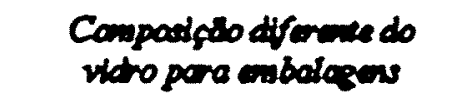 \\
\hline Vidro de Tdoristo & 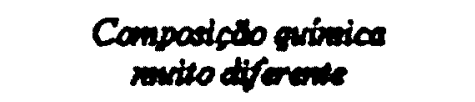 \\
\hline $\begin{array}{l}\text { Vidro Tarmo Rudxice. } \\
\text { (PireotColoned Marines) }\end{array}$ & 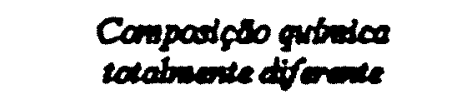 \\
\hline Rpollow & 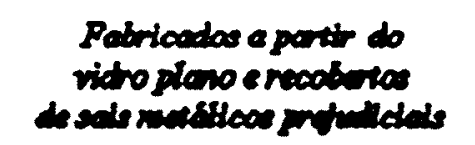 \\
\hline Varocintel & 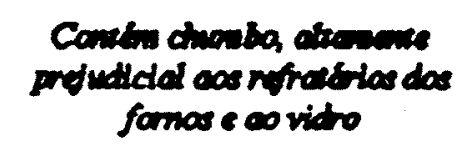 \\
\hline Limpedes Incendepenten & 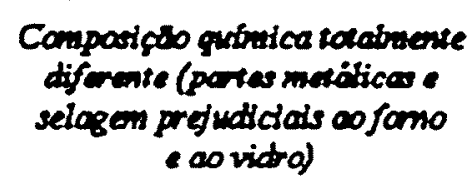 \\
\hline Llmpades Fuorescentes & 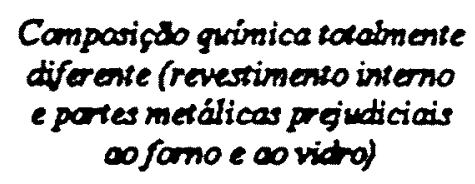 \\
\hline Fibra de VIdro & 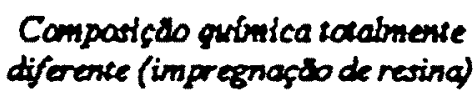 \\
\hline $\begin{array}{l}\text { Vidros Coloridos } \\
\text { (garfos cavis, vitrais, } \\
\text { vidro plano colorido) }\end{array}$ & $\begin{array}{l}\text { Contär sois metálicos colorantes } \\
\text { que podem altero a cor do vidto }\end{array}$ \\
\hline
\end{tabular}

Poote: ABIVIDRO (09) 
III.9.c. OS PLASTICOS

Dos materiais recicláveis encontrados nos resíduos sólidos urbanos o plástico é o mais recente, tendo a expansão do seu uso ocorrido a partir das décadas de 50 e 60 . As primeiras matérias plásticas foran inventadas no início do século XX. como o PVC (cloreto de polivilina) descoberto en 1913 na Alemanha(54).

\section{A incorporação do plástico no cotidiano} alterou significativamente a composicāo destes resíduos substituindo outros materiais tradicionais como o vidro e o metal. e assumindo o caráter de produto descartável(54).

Com relacào à reciclagem dos resíduos plasticos ela pode ser de três formas distintas. A reciclagem primária é a que reaproveita as sobras da produção da própria indústria (atualmente no Brasil em torno de 100 toneladas/ano o que equivale a $100 \%$ destes residuos gerados)(67).

A reciclagem secundária ou reciclagem mecànica é um método de conversāo por tusāo. das embalagens usadas em novos produtos. No Brasil existem atualmente wais de nU() industrias de reciclagem mecânica de plástico en operacão. 
comercializando os "pelleets" ou grânulos ou produzindo tubulacóes. sacos de lixo. componentes de autonóveis, bombonas para produtos químicos, engradados, etclfigura 3: 0 ciclo do Plást ico) (34.54).

Essas indústrias estão reciclando aproximadamente $14 \%$ dos resíduos plásticos presentes nos resíduos sólidos urbanos. ou aproximadamente 50000 toneladas/ano. para um potencial de reciclagem de 388000 toneladas/ano(67).

Existen algumas restricões ao uso desse material reciclado, que näo pode ficar en contato com alimentos ou remédios. e deve ter qualidade adequada à aplicação do produto resultante $(50)$.

Un dos sérios problemas encontrados e a diferente composicão química das várias resinas plásticas encontradas nos residuos descartados - que muitas vezes são incompativeis e dificultam o processo de reciclagem.Uma das solucoes encontradas pelas entidades ligadas às indústrias do plastico no Brasil. seguindo o modelo canadense e alemão. é a recomendacáo do uso dos símbolos padronizados para a identiticacào das diferentes resinas . Os produtos ŕ́gidos devem ter gravado o simbolo específico nos seus moldes ou formas de fabricacão. enquanto os filmes flexiveis devem levar a impressảo destes(67). 
A reciclagem terciária ou reciclagem química é feita a partir da despolimerização do material plástico contido no resíduo descartado. e a posterior repolimerizacão em novas resinas $(50)$.

Essa é una tecnologia de pesquisa recente. que já está sendo utilizada comercialmente pela "Shell Polyester Division". na produção do REPETE (nome dado a esse material reciclado) a partir do PET(polietileno tereftalatolpós consumo (resíduos plásticos de garrafas.embalagens ou outros produtos descartados após o consumo) (50).

A "US Food and Drug Administration(FDA)" forneceu en dezembro de 1991, certificado de não ob.jeção ( "Letter of no objection"lao uso desta resina para eabalagens de alimentos. Através de processos secundários ou terciários é reciclado cerca de $35 \%$ do PET (polietileno tereftalatol produzido nos EUA(50).

o plástico apresenta baixo peso e alto volume(11.39)e por sua estabilidade e näo biodegradabilidade. considerado por muitos o "viläo ambiental" dentre os materiais de embalagem. Apesar do Brasil ter um consumo per capita considerado 
pequeno pelos produtores de resinas e fabricantes de produtos plásticos(67). em torno de $10 \mathrm{~K} \& / \mathrm{hab} . . a n o$, enquanto Europa, Japão e EUA consomem respect ivamente 44.47 e $68 \mathrm{~kg} / \mathrm{hab} / \mathrm{ano}(43)$. sabemos que o sul e o sudeste do país, principalmente os centros urbanos mais populosos, concentram o maior consumo e o maior descarte.

A indústria de plásticos por sua vez vem. cada vez mais apoiando a incineração ou recuperação energética.principalmente nos países de primeiro mundo.como forma de tratamento dos resíduos plásticos,devido ao seu conteúdo energético e ao menor investimento necessário(54,62).

Esta solução se empregada para resolver a questăo de todos os resíduos plásticos produzidos, não seria a mais adequada. uma vez que a incineracão é uma solucão que envolve altos custos.além de ser polêmica e controvertida,pelo seu porencial de impacto ao meio ambiente e à saúde pública leliminacào para a atmosfera de substâncias tóxicas como dioxinas.furfuranos.e poluentes como clorobenzenos. clorofenóis. cádmio.arsênico.cobalto.chumbo.mercúrio.dióxido de enxofre. etc. Estudos mostram que hoie nos Estados Unidos os incineradores municipais de resíduos sāo hoje a fonte de emissōes de mercúrio para a atnosfera en mais rápido crescimento(45). Deve-se levar ainda em consideracáo que se respeitada a "hierarquia de administracão dos resíduos". deve-se priorizar a reducão nas tontes geradoras. a reutilizacáo e a reciclagem. Normalmente para 
manterem-se lucrativos com a venda de energia os incineradores devem funcionar em plena capacidade. exigindo grandes

quant idades de residuos. e portanto concorrendo com programas educativos de minimizacào destes mesmos resíduos(19). 


\section{CICLO DO PLÁSTICO}

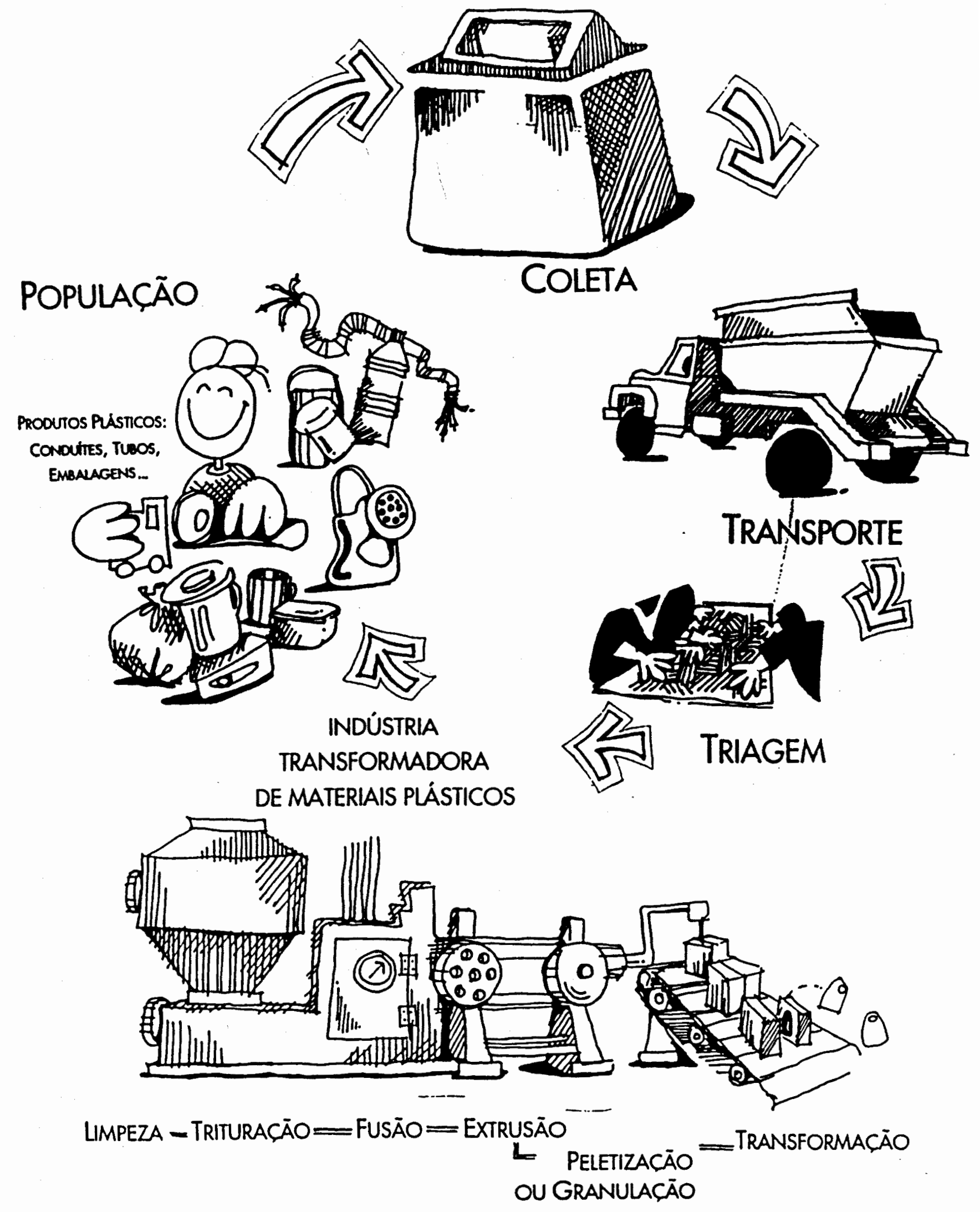

fig.4 


\section{SÍMBOLOS INDICATIVOS DE \\ RECICLAGEM E DE IDENTIFICAÇÃO DE MATERIAIS PLÁSTICOS}

Seguindo a tendência mundial, e para facilitar a reciclagem dos plásticos, as entidades ligadas à indústria do plástico recomendam que desde já sejam utilizados os símbolos abaixo indicados para identificação dos materiais. Esta recomendação atende legislaçăo que deverá oficializar e tornar compulsória a

utilizaçāo de tal sistema de identificaçāo. Os produtos rígidos deverão ter gravado o símbolo nos seus respectivos moldes ou fôrmas de fabricaçăo, e os

filmes flexíveis deverāo levar impressos tais símbolos, que indicam ser o material reciclável, bem como identificam a matéria prima.

1 - PET (Polietileno Tereftalato)

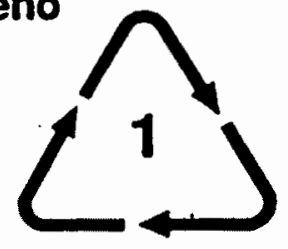

PET

3 - V (Policloreto de Vinila)

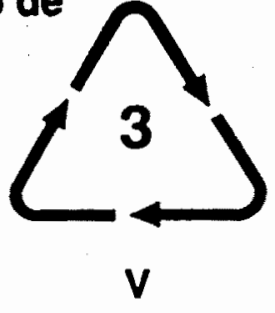

5 - PP (Polipropileno)

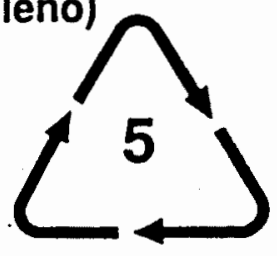

PP

7 - Outros

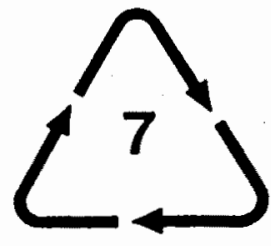

OUTROS
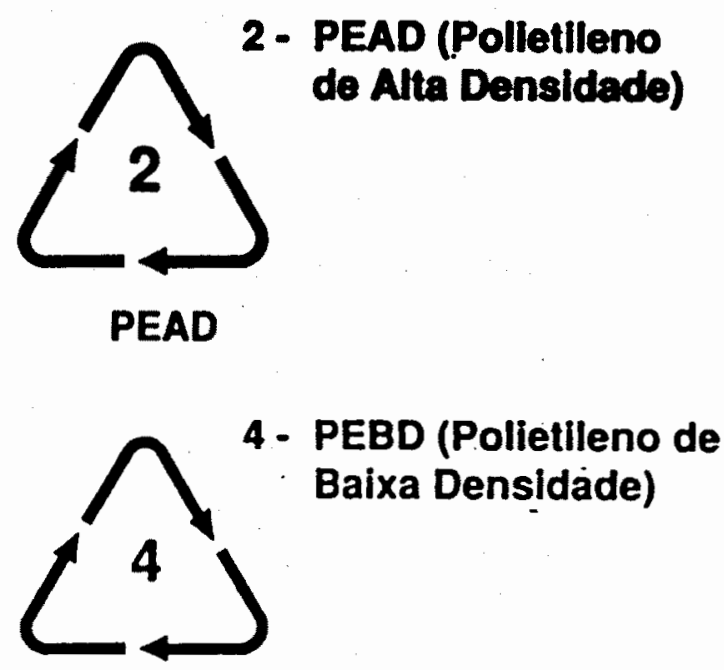

PEBD

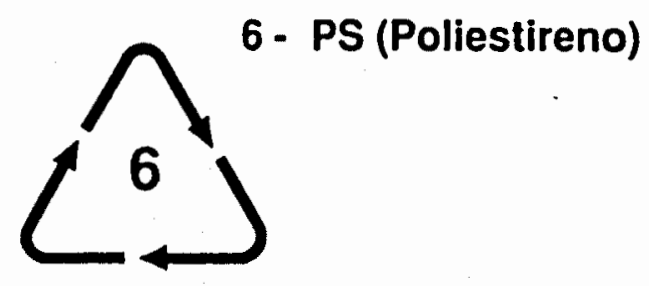

PS 
III.9.d: OS METAIS

Durante a segunda guerra cundial, a escassez de matérias primas obrigava a recuperação e a reutilizacảo de latas usadas de conservas em larga escala. Na Suica, as latas eran lavadas e cortadas alguns milímetros na parte superior do corpo e reutilizadas para outras conservas. As latas danificadas, que não podian ser reutilizadas eran utilizadas como natéria prima para outros produtos. A Suiça recuperava desta forma.cerca de $90 x$ das latas de conservas descartadas(29). Essa prática, esquecida principalmente nos países desenvolvidos durante certo tempo. ressurgiu nas décadas de 70 e 80 . devido a motivacòes econòmicas aliadas. mais recentemente, a uma maior conscientızacảo dos riscos ambientais.

Os metais sào extraídos da natureza em lorma de minerios e podem se unir formando ligas meralicas que apresentam propriedades e características diferentes dos metais que as originaram(11). Em razão das suas qualidades (entre elas a durabilidade) foram intensamente utilizados após a revolucāo industrial. podendo apresentar uma vida útil bastante grande. 
As embalagens metálicas. entretanto, a exemplo da grande maioria das embalagens utilizadas atualmente, apresentam alta descartabilidade e um tempo de vida útil pequeno, - que inclusive está em desacordo com a alta durabilidade, estabilidade e resistência das ligas metálicas normalmente ut il izadas $(32)$.

Os metais são classificados, de acordo com a sua composicão em dois grandes grupos: os ferrosos compostos basicamente de ferro. e os năo ferrosos.

Nos resíduos urbanos descartados diariamente pela população o metal não ferroso mais comu é o alumínio. A bauxita, matéria prima básica do aluminio é extraída da natureza, passando a seguir por processos que a transforman ea alumina(óxido de alumínio).Através da fundição da alumina se obtém o alumínio líquido. que é moldado e solidificado.Em seguida este material é laminado e utilizado para a confecção de uma série de produtos.o alumínio como material de embalagens só comecou a ser utilizado no Brasil a partir de 1989. tendo rapidamente ocupado todo o mercado nacional de bebidas em Iatas(57).

A reciclagem das sucatas e embalagens de aiumınio descartadas é de extrema importância para a preservação dos recursos naturais. uma vez que cada mil quilos de alumínio reciclado representa una economia de 5 mil quilos de bauxita natural.possibilita ainda a diminuicão da poluicão causada pela 
extracan desse material. e evita que esses residuos permanecam indefinidamente na natureza, uma vez o alumínio não é degradado naturalmente.

A reciclagem do alumínio representa ainda grande economia de energia. uma vez que a operação de refusāo necessita de apenas $5 \%$ da energia necessária no processo primário. As indústrias de produção de alumínio consomen cerca de $10.5 \%$ da energia produzida no país e esta é subsidiadalde acordo com a portaria 1654. de 13/08/79, as tarifas de energia elétrica das empresas produtoras e exportadoras de alunínio corresponden em média a $50 \%$ do valor pago pelo consunidor urbano, e estāo abaixo do custo real de producào desta energia(39.43.60). O alto valor comercial das latas usadas de alunínio, no mercado de sucatas(aproximadamente US $0,50 / \mathrm{Kg}$ ), facilita a coleta e portanto estimula a reciclagem desse material. Estima-se que $30 \%$ das latas de aluminio esteiam sendo recicladas atualmente no Brasil(05).

o ferro existe na natureza geralmente sob a forma de óxidos. nos minérios de ferro. dos quais é extraído. Esta extracajo acontece por meio de um forte aquecimento, em presenca de coque ou carvào de madeira. en fornos onde o óxido é reduzido.e o ferro resultante ligado ao carbono.Forma-se desta forma uma liga de terro e carbono.Este material é chamado aco. auando contem is a $2 \%$ de carbono. e ferro fundido, quando o teor desse elemento está entre $2 \%$ e 6.71321 . As embalagens metálicas para alimentos enlatados sào normalmente de aco. ou follha de 
llandres(aco com revestimento de estanho/(29). No Brasil cerca de $25 \%$ das embalagens utilizadas para conservar alimentos são latas. somando-se a isso as latas usadas para tintas e outros produtos, temos um total de 700000 toneladas de aco laminado consumidas anualmente em embalagens. Atualmente cerca de $10 \%$ das latas de aço ut i lizadas como embalagens estão sendo recicladas(05).

Tanto os metais ferrosos como os não ferrosos mantên um alto valor econômico após o descarte, pois seus resíduos ou sucata podem ser refundidos, permanecendo com as suas qualidades originais. Para o processamento da reciclagen desses resíduos ou sucatas metálicas é necessário,portanto, que estes seiam coletados, triados e encaminhados a indústria metalúrgica responsável pela produção daquele tipo de material metálico(figura 5: Ciclo do Metall). 
IV. METODOLOGIA 
Visando estudar a importância da coleta seletiva dentro de um programa de minimização de residuos e de prevencảo à poluiça, selecionamos quatro cidades do Estado de São Paulo de diferentes tamanhos, que tivessem programas de coleta seletiva com tempo de implantação superior a dois anos.Selecionamos também dois projetos de organização espontânea, também com esse tempo mínimo de implantaçāo.

o estudo foi realizado a partir de material e/ou relatórios fornecidos pelas próprias prefeituras e comunidades,dados dos estudos desenvolvidos pelo CEMPRE/Compromisso Empresarial para a Reciclagem e visitas e acompanhamentos aos programas e projetos.

\section{Foram selecionados e acompanhados os} programas de coleta seletiva de resíduos sólidos urbanos desenvolvidos nos municípios de São Sebastião.são José dos Campos.Santos e São Paulo: e as atividades de coleta desenvolvidas na Favela Monte Azul e pela COOPAMARE/Cooperativa dos Catadores de Papeis.Aparas e Materiais Recicláveis.ambas na cidade de Säo Paulo.

Consideramos neste trabalho. como residuo solido urbano aquele originado pela populacão urbana nas suas atividades. nảo incluindo nesta categoria resíduos industriais ou hospitalares. 
v. RESULTADOS E DISCUSSĀO 
- programa de Coleta Seletiva de Lixo nasceu de um trabalho realizado pelo Movimento de Preservação de São Sebastião-MOPRESS(entidade ambientalista sem fins lucrativos/. En janeiro de 1989, en reuniäo com os recḱ eleitos vereadores e prefeito. O MOPRESS colocou sua preocupação com o tratamento inadequado dispensado aos resíduos do micípio, e apresentou a idéia básica de separação doniciliar dos resíduos e coleta diferenciada ou seletiva para reciclagen.

A partir destes contatos criou-se na prefeitura a Assessoria de Educacāo Ambiental. que com uma equipe de duas educadoras iniciou a implantacảo do projeto de coleta seletiva dos residuos sólidos urbanos.

Escolheu-se um bairro central com maior porcentagem de populacão fixa. diminuindo o risco do projeto inicial vir a ser afetado pela flutuação populacional comum en municipios litorâneos: montou-se um esquema de divulgacāo através da rádio e jornal locais. faixas. carro de som e realizaram-se reunioes com a comunidade envolvida. No dia 13 de abril de 1989 foi feita a primeira coleta seletiva do material reciclavel separado pela populacào durante uma semana 
1351. A propria equipe reconheceu na época que a receptividade da populacāo foi além do esperado.(14)

Em dezembro de 1992 o programa, completando três anos e weio, tinha se estendido para 12 bairros labrangendo em torno de 15000 pessoas, cerca de $30 \%$ da populacao urbanal. contando com a participacảo de $60 \%$ a $70 \%$ dos moradores(14.15.35).

Nos bairros onde foi implantada a coleta seletiva porta-a-porta, para o recolhimento dos materiais recicláveis. estes eram chamados pela equipe implantadora, genéricamente de sucata, visando facilitar o processo de comunicação con a comunidade. Esta coleta era semanal, enquanto a coleta normal teve a sua periodicidade alterada, passando de diária para três vezes por semana, visando a dininuição dos custos.

Em outros bairros. sem a coleta porta-aporta. as pessoas encaminhavam os materiais separados para os chamados Postos de Recebimento de Sucata (implantados em 18 dilerentes pontos). que possibilitavam a participacào de mais $60 \%$ da populaçao. totalizando $90 \%$. o que considera-se uma cobertura excelente para um programa desta natureza(19).

Não podemos nos esquecer. no entanto. aue a populacảo de 45000 habitantes é multiplicada por 10. nas temporadas de verão. o que amplia tremendamente o problema do excesso de resíduos sólidos a seren dispostos,gerando maior 
necessidade de mobilizacāo. uma vez que uma "nova" populaço se soma à anterior.

A partir de 1991 o município de São Sebastiäo incorporou a coleta seletiva em algumas praias, quando da realizacảo da campanha "Operação Praia Limpa", desenvolvida pela CETESB todos os anos - com o apoio da prefeituras dos municípios litorâneos. Nestas praias o veranista além de receber um saco plástico para o recolhimento dos resíduos gerados. também recebia orientaçào dos monitores da campanha para distribui-los de forma diferenciada em 4 coletores especiais: para plásticos. latas. vidros e "lixo" propriamente ditol.

\section{Durante 25 dias no verão de 1991 só} nas praias de Juquehy, Camburi e Baraqueçaba foran recolhidos 40000 latinhas de alumínio e un total de 5 toneladas de sucata.

\section{Experiencias piloto onde a população} recebeu apenas orientacão com relacão ao procedimento de separacáo adequada. e náo foram fornecidos sacos plásticos para a coleta, tiveram um resultado excelente e devem ser ampliadas no luturn, uma vez que se mostraram mais coerentes com uma politica de desestimulo à geracảo de residuos.

Para a triagem e o armazenamento dos materiais coletados pela coleta seletiva criou-se o Depósito Municipal de Sảo Sebastiāo.constituído inicialmente por una área coberta.de 20 metros quadrados. dentro da garagen municipal. onde 
dois funcionarios da prefeitura procediam a triagem.Com a ampliacáo da coleta essa área foi ampliada para 40 metros quadrados e a triagem passou a envolver 5 funcionários.Essa estrutura era capaz de recuperar cerca de 25 toneladas mensais de material. A composicão desse material coletado encontra-se na rigura 6.

Com relaçāo à comercializacão da sucata recolhida. de acordo com Blauth, coordenadora do projeto (35) era dificil no comeco. e a prefeitura precisava procurar compradores. mas com o desenvolvimento do prograna as of ertas de compra passaram a chegar espontaneamente, e o material avaliado como de primeira linha e considerado. pela qualidade de separacảo e limpeza, un dos melhores do estado. Para a coordenadora do programa essa qualidade só foi alcançada devido ao trabalho cuidadoso con a comunidade, que progressivamente foi ampliando o seu grau de sensibilizacāo.o que era comprovado pela quantidade e qualidade do material separado e pela pequena quantidade de rejeito (quadro 1$)(15)$.

A partir do final de 1989 o vidro passou a ser vendido para a ATBIAV atual ABIVIDRO/Associação Técnica Brasileira das industrias Automaticas de Vidro. que cedeu uma trituradora. capaz de reduzir o volume do vidro a cerca de $20 \%$ do inicial. e torneceu coletoresl os chamados papa-vidros.para a coleta em postos de recolhımento voluntáriol. Essa venda direta à 
Industria possibilitou a comercializacão por um preço melhor,assim como os coletores reforcaram e ampliaram a área de atuacào do programa.

Apesar do retorno economico nao ser a meta primeira do proieto (35), o dinheiro arrecadado com a venda dos materiais recolhidos tinha como destino, entidades assistencialistas da região, escolhidas pelos moradores, e a divisảo realizada de acordo con a quantidade recolhida em cada bairro.

Essa destinação mobilizou as comunidades envolvidas. assin como as entidades beneficiadas, que inclusive elaboraram um documento destinado aos candidatos a prefeito em 1992. solicitando a continuidade do programa quando da mudança de administ racäo.

Algumas outras at ividades fizeram parte do Programa. tendo tundamental participacào nos resultados de mobilizacào alcancados. uma vez que ampliaram o universo das accies envolvendo a questão e contaram com o apoio da comunidade.

$$
\text { Dentre estas atividades destacaram-se }
$$

as oficinas de papel artesanal abertas à população. e que inclusive possibilitaram. em novembro de 1992, na Secretaria de Cultura do Municipio de São Sebastiāo. a exposicão "Expopapel $100 \%$ Reciclado". onde os papéis produzidos foram expostos. divulgando essa arte para a cidade e para os turistas. 
Foram montadas tambem reiras comunitarias

da Sucata e do Bagulho. onde foram vendidos ou trocados as sucatas de valor comercial. como utensílios donésticos, brinquedos. discos e enfeites, como estimulo valorizacāo dos obietos e a reutilização. e desestímulo ao descarte ind iscriminado ( 35$)$.

Um dado interessante colocado pela coordenadora do pro.jeto. é que a principal receita. provinha da venda dos materiais para a reutilizacão.o que confirma, tanto a possibilidade técnica quanto a econônica, da hierarquia da administracāo dos resíduos de un município.

Foi incentivado também o uso de papel reciclado em estabelecimentos comerciais e empresas, e a compostagem de resíduos orgânicos(35.57.62). 
V.1.a. METODOLOGIA DE MOBILIZACAO

A metodologia de mobilização adotada no municipio para o projeto de coleta seletiva foi " a base de encontros educativos. com a apresentacāo de diapositivos e muita conversa". de acordo con a coordenacảo do programa, o chanado trabalho "corpo a corpo". Não foran montados esquemas agressivos de propaganda e "marketing" e nem realizadas campanhas, nāo foran confeccionadas cartilhas. e näo foram distribuidos sacos para a coleta da sucata ou brindes(35).

Um dos únicos materiais produzidos e distribuidos em alguns eventos foi um folheto feito com papel reciclado. trazendo informacöes claras e precisas 1 ver tolheto anexo. do municipio de Sào Sebastiàolque colocavam claramente o porque da necessidade de participação de cada pessoa. destacando a importância de se diminuir a poluicão ambiental e evitar o saturamento dos lixōes. de se evitar o desperdício de matérias primas e energia .de se colaborar com a limpeza e saúde pública e com as entidades favorecidas com a venda dos materiais recolhidos. 
Os ob.jetivos do projeto ficaram claros nas palavras de Blauth. Concalves e Martins(35), idealizadoras e executoras do projeto:" o lixo foi um pretexto. un ponto de partida, para sensibilizarmos as pessoas para os problemas do nosso ambiente urbano. assunto que perdia para as questões ecológicas ligadas à Amazônia, às campanhas pró-baleias, os vazamentos de petróleo e outras causas preservacionistas mais ou menos distantes. Embora ho.je as pessoas saibam que todos nós afetamos o ambiente. elas também estāo aprendendo como diainuir o impacto negat ivo de seus estilos de vida". E ainda "o incentivo a reflexào individual sobre as posturas das pessoas em relação ao ambiente. através da discussāo sobre o lixo. certamente contribuiu para o redespertar de um carinho para com a rua, o bairro. a vizinhança. Hoje. a comunidade sebastianense inegavelmente se preocupa mais com a cidade. o que fica evidente no crescente interesse pela manutencão das vias públicas. pela conservacảo do patrimônio histórico. pela arborizacão e pelo saneamento básico. Acreditamos que educacão ambiental e educacão para a cidadania sāo. pura e simplesmente. Educacāo"(35). 
FIGURA 6 - SÃO SEBASTIÃO

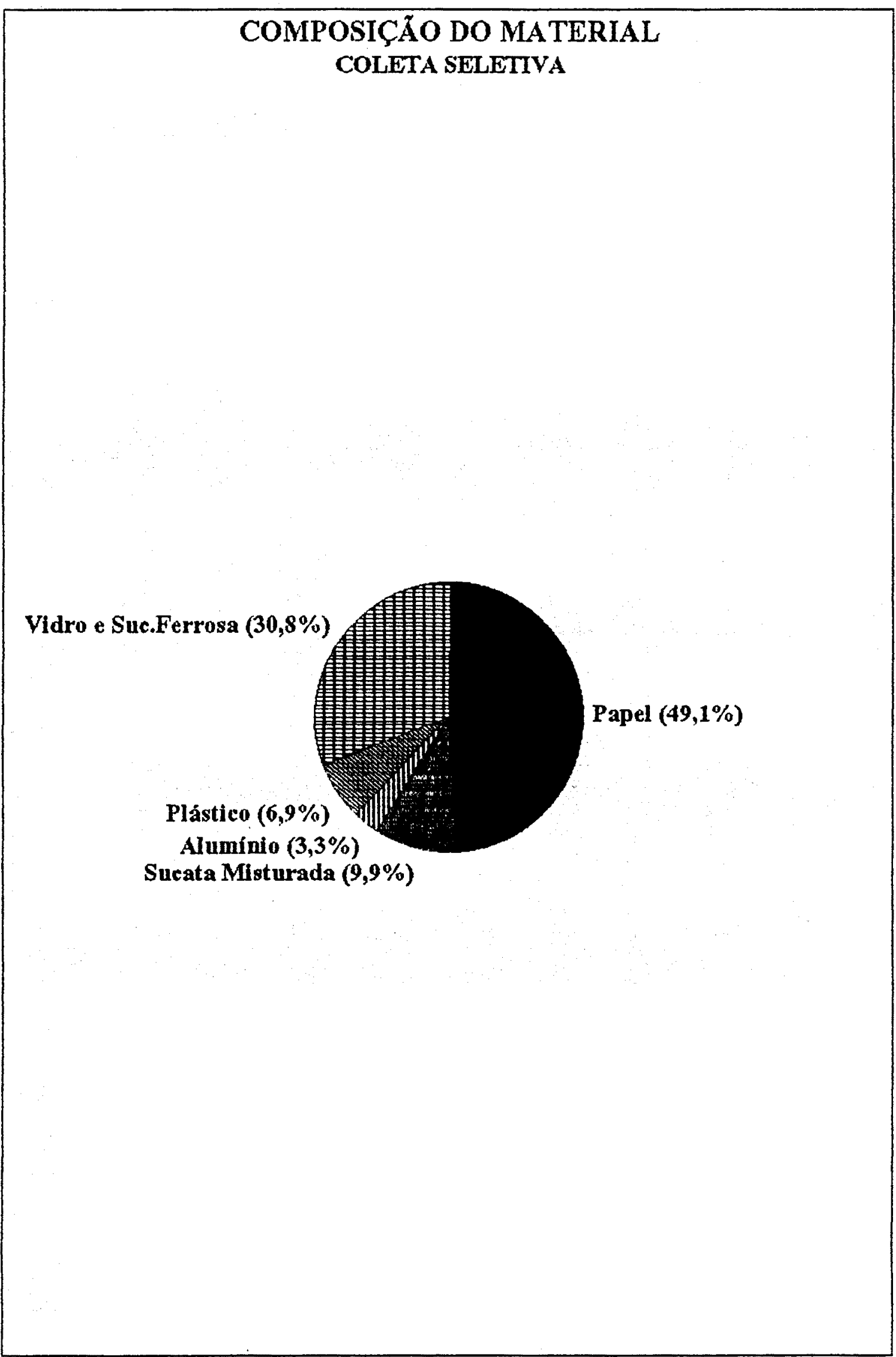

Fonte: PREF. MUNICIPAL DE SÃO SEBASTIÃO (14) 


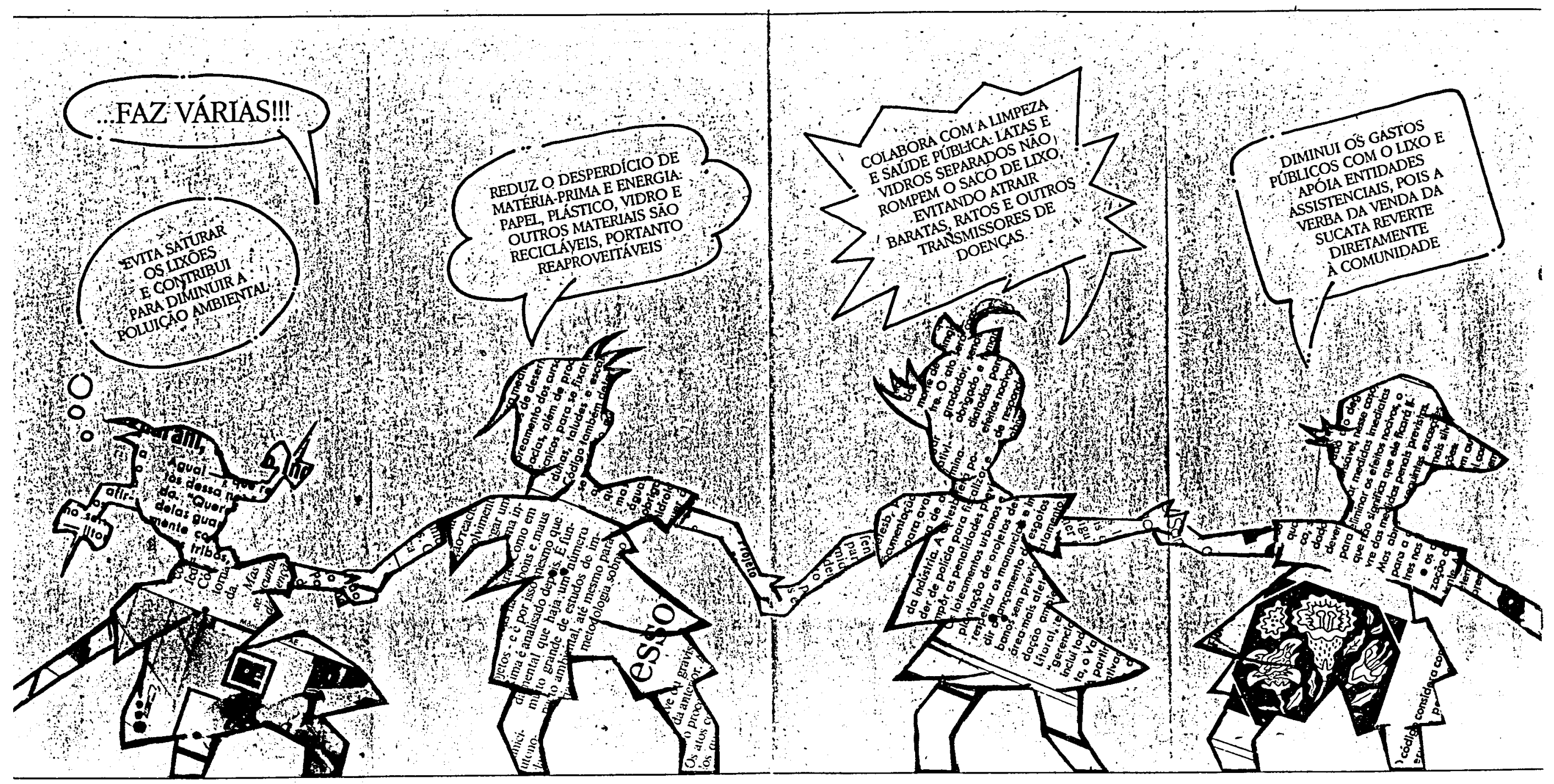




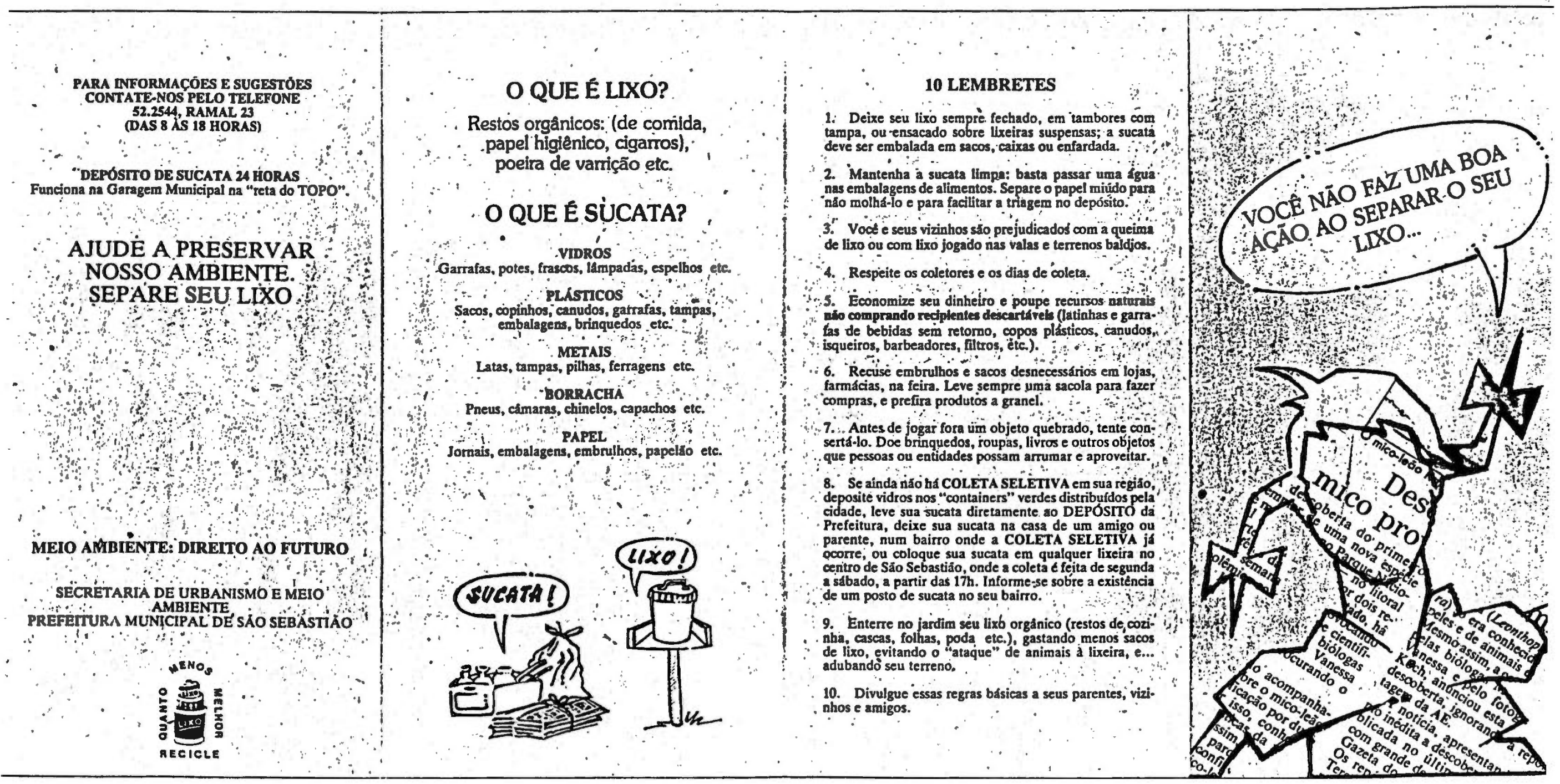


V.2. A EXPERIENCIA DE SÃO JOSE DOS CAMPOS

São José dos Campos, cidade de aproximadamente 460000 habitantes. É considerada a "capital" da regiāo do vale do rio Paraíba, tendo, como polo industrial, os problemas ambientais comuns ao processo de industrialização brasileiro(01).

- prograna de coleta seletiva de resíduos sólidos urbanos foi iniciada en novembro de 1990, pela Assessoria de Meio Ambiente da Secretária de Planejamento e Meio Ambiente da Prefeitura Municipal(35).

Desde 1989 a equipe técnica desta assessoria havia desenvolvido estudos a respeito das formas de coleta seletiva. com o ob.jetivo de encontrar aquela mais adequada à realidade da cidade. que iá contava na época com uma área especifica para tratamento e disposicão final dos resíduos gerados no município. integrada por um aterro. uma usina de compostagem desativada e um incinerador. 
O objetivo básico para a implantação deste projeto era a necessidade de se aumentar a vida útil do aterro municipal. con a diminuicāo nas fontes da quantidade de residuos gerados, e a minimização dos resíduos sólidos a serem dispostos. despertando a populacão para a responsabilidade de cada um na producão diária destes resíduos(06.56).

Este programa, que recebeu o nome de "Luxo do Lixo". teve início en novembro de 1990 a partir de uma experiência piloto em dois bairros(01).

A partir da necessidade de açōes que levassem a un processo de conscientização onde limpeza urbana estivesse relacionada con saneamento básico, saúde, qualidade de vida e preservação ambiental. foi desenvolvido no infcio de 1992 - Projeto São José Verde Limpa. como programa de educação ambiental. envolvendo em um primeiro momento a comunidade escolar e num segundo a comunidade como un todo $(56)$.

Esse programa consistiu no desenvolvimento de atividades conjuntas entre a Assessoria de Meio Ambiente. a Secretária Municipal de Educacão. e as escolas da rede municipal.estadual e particular 101.561 .

Desse momento em diante os dois programas caminharam iuntos. uma vez que. através do tema reducão e reciclagem dos residuos urbanos, iniciaram-se ações que tinham como meta fornecer informacōes e experiências concretas llevan- 
tamento da composicāo dos residuos produzidos na própria família, visitas ao aterro sanitário, reconhecimento de áreas com disposicão inadequada de resíduos nos bairros. cidade, regiāo. etcl. que levassem à reflexāo e à discussão da relação de cada um com o seu ambiente. e das formas de participação na resolucão dos problemas $(06.56)$.

Quando da instalacão do projeto, já se partiu da necessidade de reutilizacão, uma vez que a partir de très caminhöes antigos que estavam inativos no depósito da prefeitura. reconstruiu-se o primeiro caninhão utilizado na coleta seletiva, aproveitou-se ainda a esteira da antiga usina de compostagem desativada, e utilizou-se una oficina abandonada próxima ao aterro sanitário. como local de separação(01).

Decidiu-se pela implantacão de dois tipos de coleta seletiva. a coleta porta-a-porta e a coleta nos pontos de entrega voluntária ou PEVs. Na coleta porta-a-porta a populacão era instruida para separar os materiais potencialmente recicláveis (plásticos.metais. papéis e vidros). do lixo comum iorgänıcos. restos em geral náo recicláveis e lixo de banheirol.

$$
\text { Os residuos recicláveis eram }
$$
acondicionados pela populacão em um único recipiente ou saco de plastico ou papel.Este residuos separados eram recolhidos uma vez por semana. em dias e horárıo fixos e pré estabelecidos. por uma equıpe de um motorista e três coletores.os coletores muitas vezes recebiam o material das mãos da dona de casa ou da empregada 
donestica. que aquardavam o toque dos sinos do caminhäo da coleta seletiva(01).

Estes materiais eram recolhidos e acomodados em caminhỏes (em Sảo José dos Campos foram utilizados dois caminhóes. um "Chevrolet" de carroceria baixa reconstruido. iá citado. e um caminhäo tipo "baú" adaptado pela empreiteira Rek para a coleta seletival, para serem separados no local de triagem $(01)$.

Até o início de 1993. contava-se com 17 circuitos. que foram escolhidos após a avaliação da viabilidade da coleta e através do contato direto com a populacão. priorizando-se os bairros onde a demanda por este tipo de servico estivesse aliada à organização da comunidade, através de sociedades amigos de bairros. entidades culturais ou ambrentalistas, organizacōes assistencial istas. etc(01.56).

A coleta através dos pontos de entrega voluntaria ou PEVs. contava com vinte coletores cedidos pela ABIVIDRO/Associacảo Técnica Brasileira das Indústrias Automáticas de Vidro. espalhados por supermercados e escolas da cidade. Cada norador era instruido para separar o vidro descartado em casa. levando ao local de coleta e depositando nos coletores ou 'bapa-vidros" .como eles eram chamados no programa implantado nela preteicura. Esses materiais eram recolhidos por peruas "Konbi" da prefeitura municipal. que também atendiam solicitacōes para coletas esporadicas $(01.06)$. 
A coleta e a triagem dos materiais estavam a cargo da URBAM-Urbanizadora Municipals.A. que é uma empresa prestadora de servicos. de capital misto. cuja acionista maloritaria é a Prefeitura Municipal. A composicão desse material encontra-se na figura 7.

Todos os materiais coletados eram encaminhados ao Galpāo de Triagem. e em seguida triados em uma esteira rolante de 6 metros de comprimento, retirada das antigas instalaçoes da Usina de Compostagem e adaptada no Galpão. A catacāo era realizada por 17 catadores que atuavam na triagem e estocagem dos materiais. separando cacos de vidro e garrafas inteiras. que eram triturados: separando alumínio, papel branco de primeira. papelão e aparas de papel em geral, metais ferrosos. plásticos moles (tipo filme) e plásticos duros misturados. Pneus também eram separados e vendidos para labricantes de calcados. ou móveis como sofás. da região do Vale do Paraiba(01.06).

Os outros materiais após a triagem eram estocados em baias cobertas. As vendas eram feitas em média uma vez por semana. Estas áreas cobertas estavam adequadas ao fluxo dos materiais coletados. sendo as áreas laterais descobertas ocupadas apenas por materiais de grande porte(06).

A verba arrecadada era encaminhada à INIPAS-Unidade Participativa de Acäo Social, uma entidade com tins assistenciais. que repassava a verba para as comunidades 
carentes do Programa de Habitacão Alternativa(01.06). A UNIPAS. desta torma. mantinha uma fábrica de blocos. onde os interessados. normalmente pessoas de baixo poder aquisitivo, se inscreviam e quando chamados. fabricavam os seus próprios blocos, doando 10\%, que eram encaminhados à programas de ajuda à deticientes. No momento da realizacão deste levantamento as casas populares estavam sendo construidas no bairro "Campo dos Alemaes"(06). 
V.2.a. METODOLOGIA DE MOBILIZACão

A metodologia adotada neste programa foi decidida a partir de estudos e visitas às experiências de são Sebast iao e Curitiba: optando-se pelo lancamento do programa em dois bairros-piloto englobando cerca de 700 residências(35).

\section{Foram feitas reuniōes envolvendo a} comunidade em escolas, igrejas e outros setores organizados, como Rotary. Lions. Lo.ja Maçônica. Associação Comercial, etc.

\section{A proposta era a de que cada familia} fosse contatada e mobilizada. para que tivesse condições de se envolver com o programa. Este previa inicialmente. ensinar a comunidade envolvida (moradores, funcionários e usuários) dos hairros envolvidos. a segregar o lixo na fonte geradora. isto é. resıdèncias. escolas. escritórios.etc. $(06.56)$. 
Nao foram distribuidos sacos de qualquer natureza para a coleta dos materiais recicláveis. uma vez que se definıu ser de fundamental importância o reforço da idéia de reaproveitamento e o combate ao desperdicio. estimulando cada famılia a adotar suas próprias soluçōes a partir da reutilização de caixas. sacos de supermercados, etc(35).

Também foi considerado de fundamental importância a não realização de trocas(material reciclável por vale-tranporte ou vale-alimentaçào,por exemplo), ressaltando que a participacáo deveria estar vinculada a uma real conscientizacão dos beneficios ambientais e sociais, e não a um possível lucro ou retorno tinanceiro (35). O trabalho de mobilizacão e educacão ambiental. feito principalmente a partir do contato direto com a populacão (o chamado "trabalho corpo-a-corpo"), foi desenvolvido com o objetivo básico de proporcionar oportunidades de participacáo consciente da populaçäo.

Além da importância da reciclagem e da preservacáo ambiental. os conceitos de reaproveitamento e de combate ao desperdício também foram reforcados durante todo o proieto. Nos folhetos utilizados para a divulgação, tanto da coleta porta-a-porta quanto de estímulo à utilização dos postos de coleta / ver folhetos anexos.do município de São José dos Camposificavam claras as mensagens de que o grande retorno é com relacao a economia de recursos naturais. de energia e de áreas para disposicảo final. salientando a importância da prevencāo à poluicao e aos problemas de saúde püblica. 
Um dado interessante é que nas escolas. estes folhetos. muitas vezes. nảo funcionavam como material descartavel. uma vez que eram entregues aos alunos para serem lidos e depois devolvidos e reutilizados por outras turmas(35).

o proieto foi sendo ampliado e no final de 1992 abrangia. em 17 bairros, um total de 13100 residencias. correspondendo a uma população de cerca de 56000 habitantes. Para cada novo lançamento. cada morador era visitado e convidado a participar do pro.jeto(06).

De acordo com Assis. coordenadora do proieto. durante todo o trabalho. "ressaltou-se a importância do repasse à populacão dos conhecimentos a respeito dos processos produtivos. das consequencias da utilizacăo indiscriminada dos recursos naturais e da disposicào inadequada dos residuos. e ainda. da real importância da reciclagem dos materiais neste contexto mais amploivol.

A participacáo da comunidade foi na maior parte das vezes considerada surpreendente. com a populacão separando seus materiais recicláveis. e inclusive limpando-os ances da entrega. facilitando as etapas posteriores e valorizando o material para a revenda 101.351 .

Para a equipe o sucesso do programa foi resultado das campanhas de esclarecimento e das acōes de educacão ambiencal. De acordo ainda com a coordenadora do projeto." após o 
inicio do trabalho com a coleta seletiva. percebeu-se um aumento do cuidado com a limpeza urbana por parte da populacão envolvida. e uma maior preocupacão com a preservacão ambiental e a qualidade de vida"106).

o proprio relatório do Cempre-Compromisso Fmpresarial para Reciclagem. considerou que os benefícios sociais e ambientais. nas suas dimensōes mais amplas. são difíceis de serem destacados e quantificados em relatórios técnicos(01).

Também o surgimento de iniciativas de grupos da comunidade. que espontaneamente cooperavam com o programa.toi considerado excelente resultado. Nestes casos grupos de moradores de diferentes bairros, muitas vezes integrantes de entidades ligadas à Igreja Católica Romana, se uniam. viabilizavam a coleta seletiva de materiais recicláveis e escolhiam lugares adequados para a estocagem. solicitando em seguıda retiradas semanais pela prefeitura municipal(01). 
FIGURA 7 - SÃO JOSÉ DOS CAMPOS

\section{COMPOSIÇÃO DO MATERIAL \\ COLETA SELETIVA}

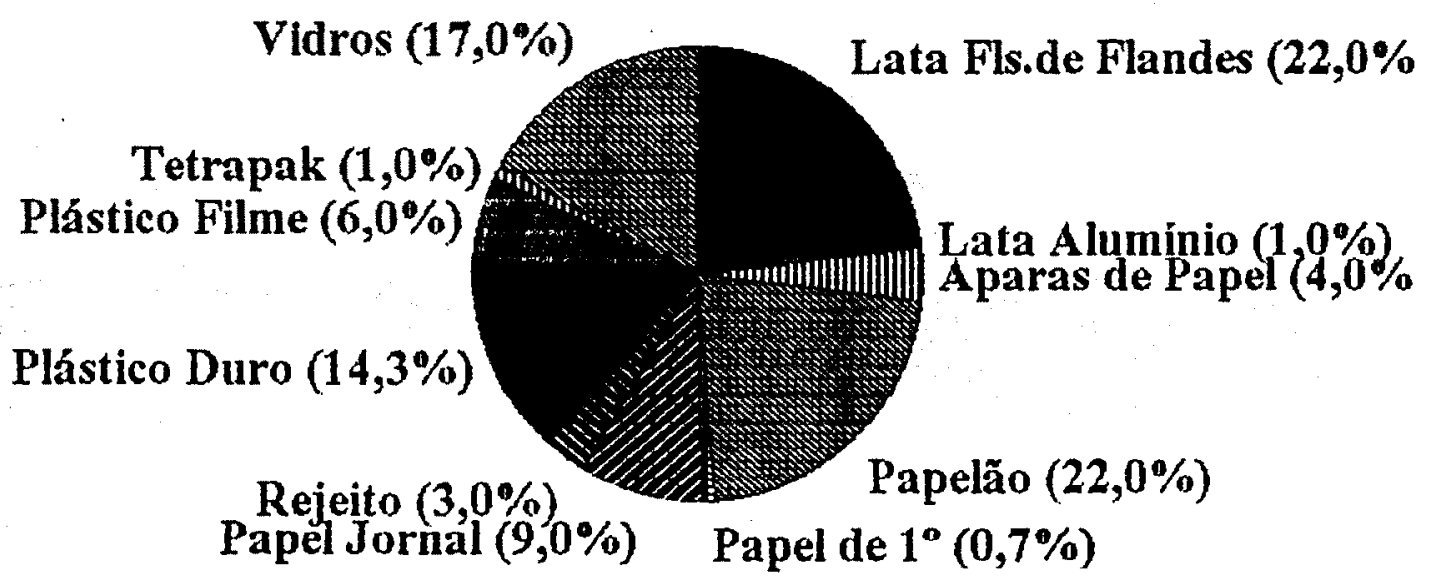

Fonte: CEMPRE ( 01 ) 


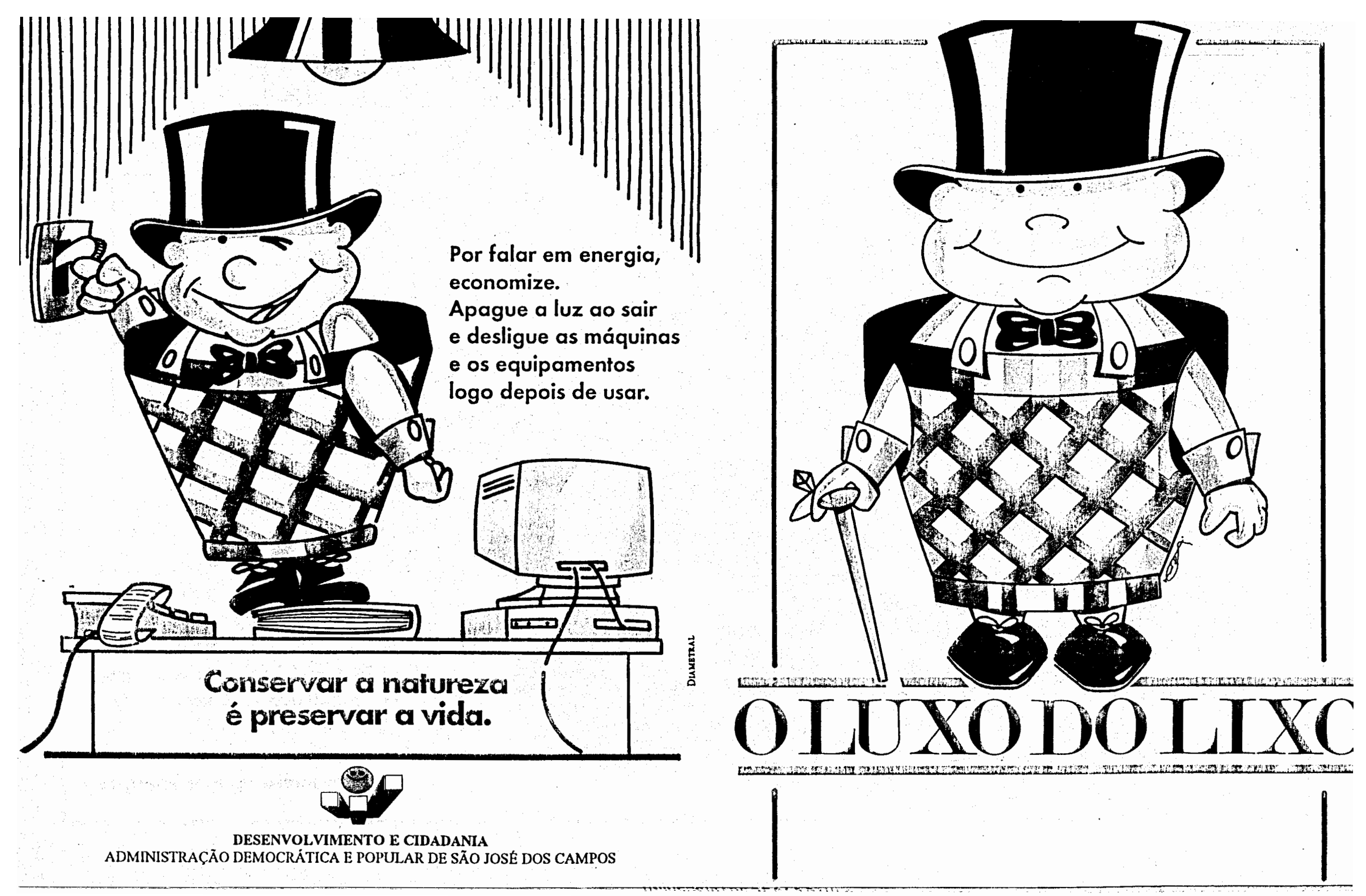


A gente separa o lixo que não é lixo, isto é, o luxo: papel, vidro, plástico e alumínio. Depois, esse material é vendido para ser reciclado. Com o rendimento, a Unipas

faz casas populares.

Colabore com essa iniciativa. Mas não desperdice.

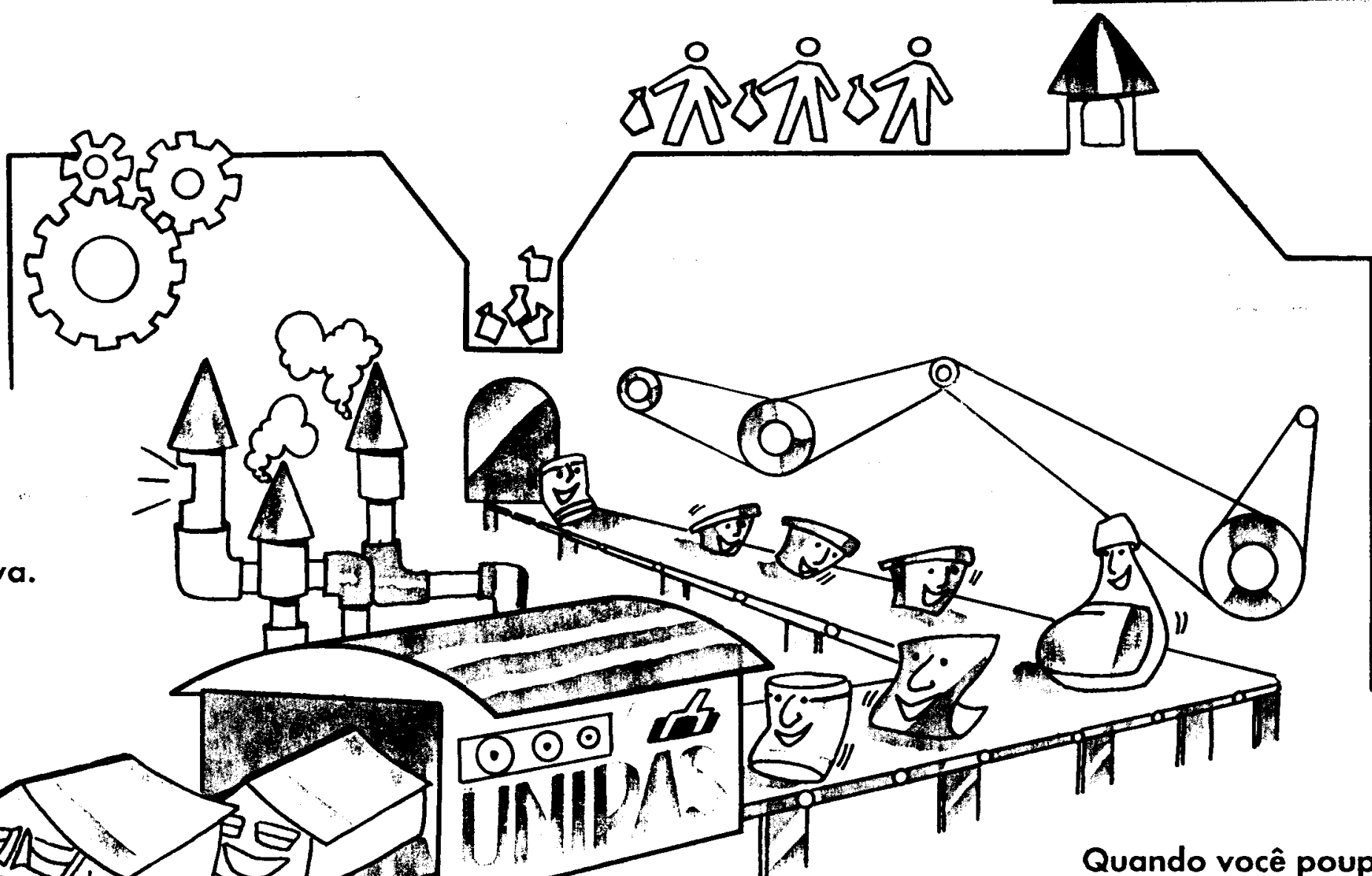
- luxo do lixo você poupa a natureza. Porque o vidro é feito de areia, o papel é feito de madeira, o plástico vem do petróleo
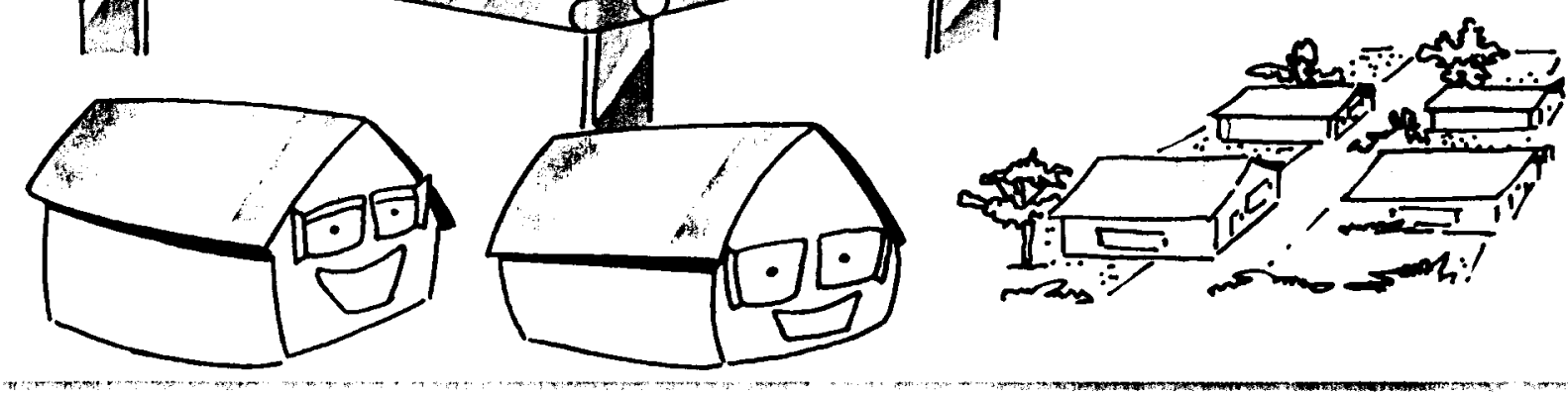
o alumínio vem da bauxita. Além disso, todo o processo industrial gasta muita água e energia. 
Você sabia que papel é feito de árvore? Cada $50 \mathrm{~kg}$ de papel usado, transformado em papel novo, representa economia de 1 (uma) árvore.

Assim como o papel, também plásticos, o vidro, as latas, todos estes vêm da natureza, reaproveitálos... a natureza agradece.

E ainda sem o Luxo do Lixo, o aterro sanitário, que é o lugar onde se joga o verdadeiro lixo (papel higiênico, fralda descartável, absorvente higiênico), terá mais espaço, e assim poderá receber lixo por mais tempo; conseqüentemente teremos menos áreas poluídas em nosso Município.

Tem ainda um outro grande benefício, porque o Luxo do Lixo, será vendido, e o dinheiro aplicado em benefícios aqui mesmo em nosso Distrito.

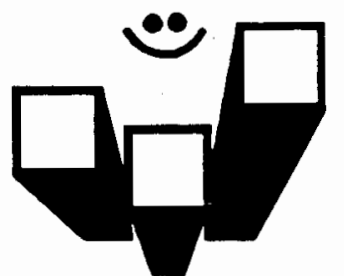

DESENVOLVIMENTO E CIDADANIA ADMINISIRACÃO DEMOCRÁTICA E POPULAR DE SÃO JOSÉ DOS CAMPOS

\section{SUB-PREFEITURA DE SÃO FRANCISCO XAVIER}
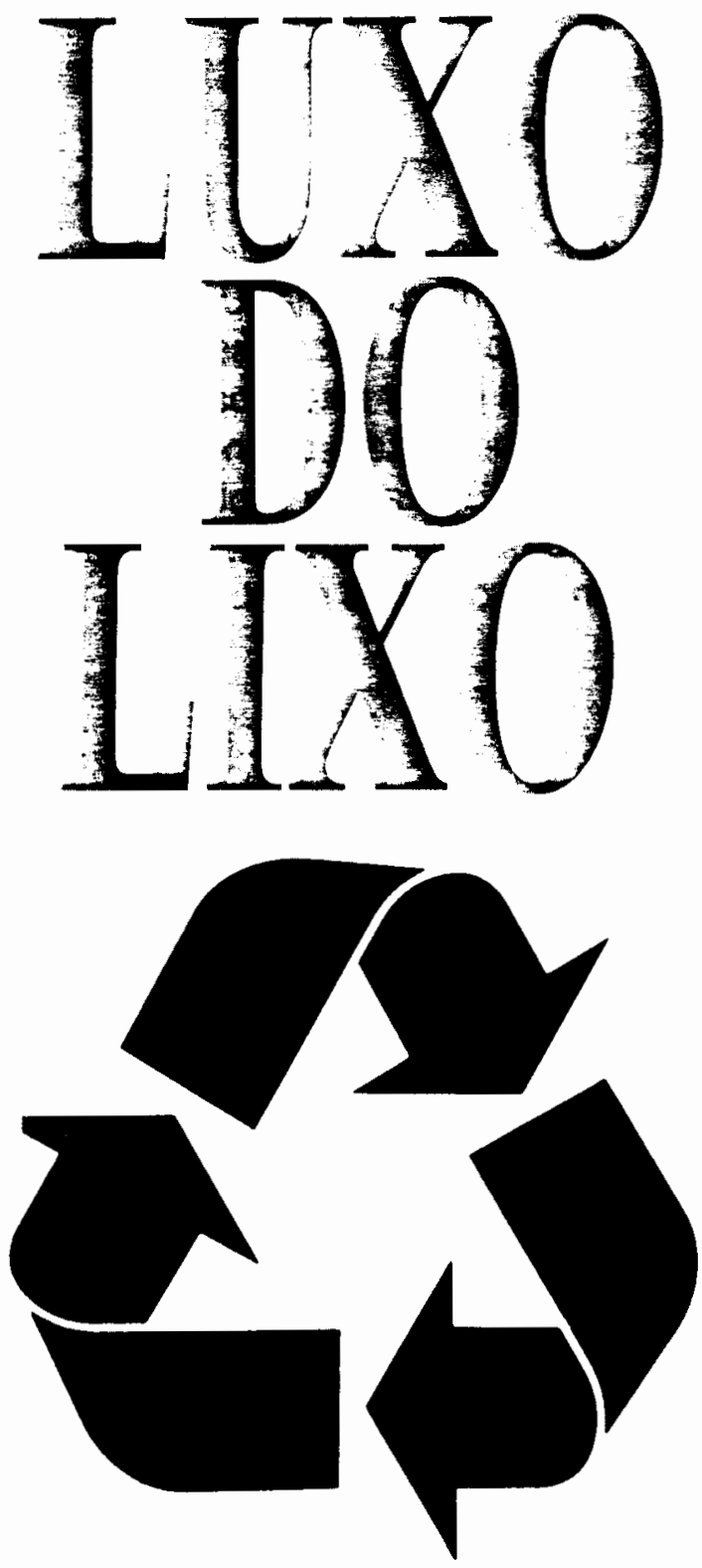

São Francisco Xavier por sua beleza natural, suas montanhas, suas águas limpidas, por seu verde ainda preservado, agora é APA - ÁREA DE PRESERVAÇÁO AMBIENTAL.

Todos nós temos que cuidar para que 0 nosso Distrito fique cada vez mais bonito, e a nossa vida cada vez melhor. 


\section{Esiamos começando pelo lixo.}

O lixo jogado em qualquer lugar pode ser um problema. Um problema para a nossa saúde, porque vai juntar ratos, baratas, moscas que trazem doenças para todos nós. E, é ainda problema também para a natureza, porque contamina o solo e polui.

\section{Não queremos viver num ambiente sujo. Poluição, não!}

Você sabia que quase tudo aquilo que hoje jogamos no lixo, não é lixo? Que o nosso lixo é o mais rico do mundo? Que jogar papel, papelão, plásticos, vidros e metal no lixo, é um LUXO?

Esses materiais, limpos, podem ser reaproveitados, podem ser reciclados. Podem voltar para a indústria e se tranformar em um novo produto.

E aqui em São Francisco nós também vamos separar esses materiais, da seguinte maneira: Vamos ter vários tambores, cada um de uma cor, colocados em alguns pontos do nosso distrito. $E$ em cada um destes vamos colocar um tipo de material.

\section{VAI SER ASSIM:}

Revistas, jornais, Caixa de papelão, Embrulhos

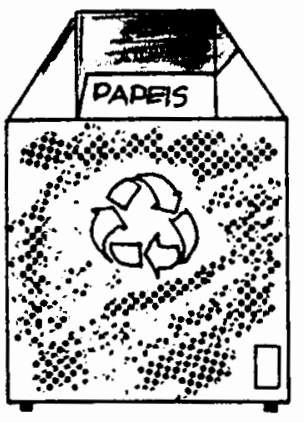

Latas (refrlgerantes, cervejas, óleo, conservas otc.), arames, pregos, tubo de pasta de alumínio, cobre e outros.
Vidros, garrafas, copos, frascos de remédios, cacos etc.

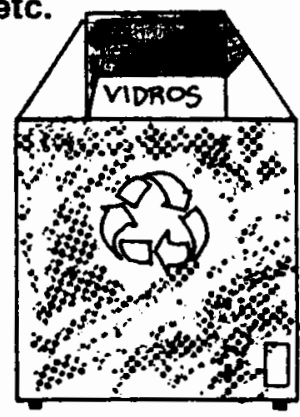

Potes (de todos os tipos) embalagens (detergente, shampoo, vinagre otc.), tampas, sacos (de leite, arroz) e outros.

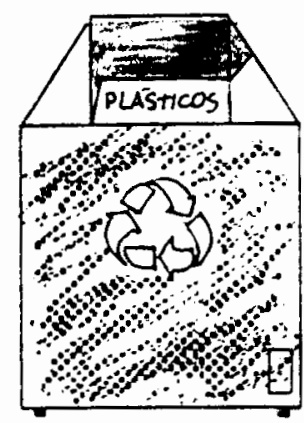

\section{A T E N Ç $\tilde{A} O$}

Papel higiênico, fraldas descartáveis, absorventes higiênicos não podem ser colocados nos tambores, porque são sujos.

Separar estes materiais, isto é, separar O LUXO DO LIXO, representa economia de natureza e gera benefício social. 


\section{v.3. A EXPERIENCIA DA PREFEITURA DE SANTOS}

A Prefeitura de Santos criou em fevereiro de 1990. o Grupo Técnico do Lixo Reciclável. formado por técnicos tas secretarias da Higiene e Saúde. Educacào e Abastecimento. do Departamento de Projetos e Acảo Comunitária. do Grupo Executivo de Meio Ambiente e da PRODESAN / autarquia municipal responsável pela limpeza urbana do municipio de Santosl.

Este grupo tinha como finalidade básica a organizacáo do projeto piloto de coleta seletiva, levando em conta as questóes sociais. ecológicas e de saúde pública. econonnicas e educativas. $(35.60)$.

$$
\text { Optou-se pela implantacáo em dois }
$$

bairros. com onpulacao fixa e pequeno número de prédios. visando lacilitar $n$ trabalho com a comunidade(35). Essa implantacão rontecell em main de 1990. abrangendo inicialmente 8000 residencias e envolvendo cerca de 28000 habitantes. servidos uma vez por semana pelo sistema de coleta seletiva porta-a-porta. Esses bairros contavam também com postos de entrega de vidro. com colecores fornecidos pela ABIVIDRO, a partir de convênio com a preteitura municipal $(69)$. 
Além da ampliacāo gradual do projeto para outros bairros (em setembro de 1990 o projeto abrangia cerca de $\$ 2000$ habitantes em um total de 12000 domiciliosl. a coleta diferenciada envolveu escolas. estabelecimentos comerciais. industrias. prédios publicos. entidades diversas e condomínios, e tambem a implantaçào de novos Postos de Entrega Voluntária (PEVs) e de novos postos de entrega de vidro da ABIVIDRO em outros bairros $(35.69)$.

Em iunho de 1991 foi desenvolvida uma campanha para coleta de papel de primeira, para confeccão de cadernos escolares. que foram distribuídos, em 1992.aos alunos da rede municipal de ensino. Foram distribuídos 200000 cadernos que custaram aos cofre públicos na época Cr\$30milhōes e custariam Cr\$150 milhöes. se fossem comprados em uma licitacão normal, isto é. Se as aparas de primeira coletadas não entrassem à base de troca na negociacãol 69$)$.

Em setembro de 1992 inauguraram-se as novas instalacoies da usina de separacào. e a maior parte dos trabalhos passou a ser feita em galpöes cobertos(69). Em novembro de 1992 o "Programa Lixo Limpo" de coleta porta a porta semanal. abrangla 9 bairros e cerca de 144000 moradores $125 \%$ do cotal da populacáo. incluindo os vários extratos sociaisl, além uns coletores em 'Postos de Entrega Voluntária/PEVs em très pontos ta cidade. recolhendo de 100 a 120 toneladas mensa1s $(35)$. 
O "Programa Lixo Limpo" abrangia ainda 77

escolas. cerca de 30 estabelecimentos comerciais e industriais. 15. prédios publicos. 40 postos de entrega voluntária de vidro. alen de 50 condominios e grupos de moradores $(35)$.

A partir da coleta. o material era encaminhado para a usina de separacāo onde 55 pessoas trabalhando 4 horas diárias (quarenta homens de rua e quinze pacientes exinternos da Casa de Saúde Anchieta), procediam a separaçāo em galpäo coberto de $1200 \mathrm{~m}$. Como foi relatado anteriormente essas novas instalacỏes foram inauguradas em setembro de 1992 (até esta época a descarga e parte da separação era feita a céu abertol(60,69), a composicão desse material coletado encontra-se na figura 8.

Com relacão à comercialização. procediase a licitacoes. vencendo os potenciais compradores que melhores condicões oferecessem para cada material. o vidro coletado era vendion diretamente para as industrias. através de convênio com a ABIVIDRO. Os materiais que nảo alcancassem o valor minimo exigido para a licitacào. devido principalmente às pequenas quantidades coletadas, eram vendidos através de cotaçäo quinzenal de precos a sucateiros ou interessados da região(69).

Desta forma, latas de aco. ferro. bronze e cobre eram normalmente vendidos por meio de cotação quinzenal. enquanto papel. vidros. plásticos eram objeto de licitacão. 
A verba arrecadada era aplicada em

programas de reintegracão social, de homens de rua e dos ex pacientes psiquiátricos. que atuavam como separadores desse programa. Esta atividade remunerada era fundamental na reintegracăo social destas pessoas(35).

Parte da coleta em estabelecimentos educacionais e comerciais era realizada por "catadores" da Associacão dos Carrinheiros de Santos(cerca de 50),que de forma independente. comercializam o material(60).

- Programa tentava integrar sempre que possivel essas pessoas. que tradicionalmente já realizavam a coleta espontânea dos materiais recicláveis em Santos, existindo na ocasião deste levantamento, aproximadamente 500 "catadores." que coletavam em torno de 40 toneladas por dia destes materiais.principalmente metais e papéis(35.69).

$\mathrm{Na}$ impossibilidade de integracão da malor parte dos catadores ao programa optou-se por orientar a mpulacao para cont inuar entregando os materiais separados ans carrinheiros ou catadores(35).

Empresas da regiảo também estavam envolvidas na coleta seletiva de materiais. principalmente de papéis. caso da Telesp. Citrosuco. Petrobrás.Caravel e várias outras(00.62). 
V.3.a. METODOLOGIA DE MOBILIZACAO

Os ob.jet ivos essenciais da implantacão do Programs Lixo Limpo de Santos, foram a redução do volume de residuos destinados ao aterro, e a conscientizacão da população para a importância da reciclagem. como parte das soluções integradas para a questào dos resíduos sólidos urbanos(35).

Na implantacão o Programa foi divulgado por campanhas publicitárias lout-doors. mensagens em rádios e iornais. faixas. placas de rua e material informativo e eventos (gincanas e pecas teatrais).

Foram realizadas reuniōes com as
comunidades envolvidas e. a partir das primeiras delas. e de
propistas de cursos que mobilizassem para a questào. foi
realizado um prineiro curso para 30 moradores. que deu
nrigem a uma iomissajo de acompanhamento do proieto.

Essa Comissão. inclusive em fevereiro de 1492. iuntamente com outras entidades. iniciou uma coleta de assinaturas propondo. a partir de uma emenda popular a alteracáo da Lei orgànica do municipio. garantindo a obrigatoriedade da coleta seletiva(35). 
tpós a implantacào do Programa foram envolvidas as escolas da rede municipal. a partir de reuniões e de propostas de integracáo ao curriculo. uma vez que de acordo com Souza e Andrade. da coordenacào do projeto: "A problemática do lixo vem no bojo de discussöes sobre: a ocupacão do espaco urbano e rural, o saneamento básico. o patrimônio natural e histórico. as condicōes de vida da população-aspectos relacionados com outras localidades e trabalhados em todas as àreas do conhecimento, interdisciplinarmente,garantindo uma visào do ambiente natural e construido" (35).

Foi entāo estabelecido com as escolas locais um calendario anual de eventos abordando o tema resíduos e reciclagem $(60)$.

Para a divulgacão utilizou-se um personagem:o Sr.0limpo - símbolo do Programa Lixo Limpo. que em folhetos distribuidos conclamava a participacāo da populacão. intormando a respeito dos materiais recicláveis e das vantagens da reciclagem. de como proceder com relacão aos resıduos comuns ou orgànicos. de formas de participạcão dos moradores dos prédios. dos horários e dias de coleta em cada baırro. e ainda da importäncia de doacōes e da colaboracào com os carrinheiros e catadores (ver folhetos anexos. do município de Santosi.

o Sr. ilimno também foi utilizado iunto às escolas da rede municipal. em folhetos adequados ao publico infantil. com iogos e brincadeiras ligadas ao tema 
residuos. limpeza urbana e saude publica (ver folhetos anexos do municipio de Santos/. Cartazes com a sua ligura "viaiavam" nos ônibus das linhas que serviam aos hairros alvos. visando divulgar e familiarizar a populacão com o personagem simbolo do "Programa Lixo Limpo"(35.69).

Em novembro de 1992. mais da metade do total de escolas de Santos (77 de um total de 144) estavam efetivamente participando do Programa. e separando o seu "Lixo Limpo" (60).

Durante o decorrer do Programa foram realizadas. além das reuniōes e cursos ."oficinas de papel" laulas de confeccão de papel artesanal a partir de aparas de papell, que tinham como meta sensibilizar educadores e público em geral para a necessidade do uso adequado e do combate ao desperdicio desse material. além de explorar o lado criativo da conteccán do papel reciclado(35). 


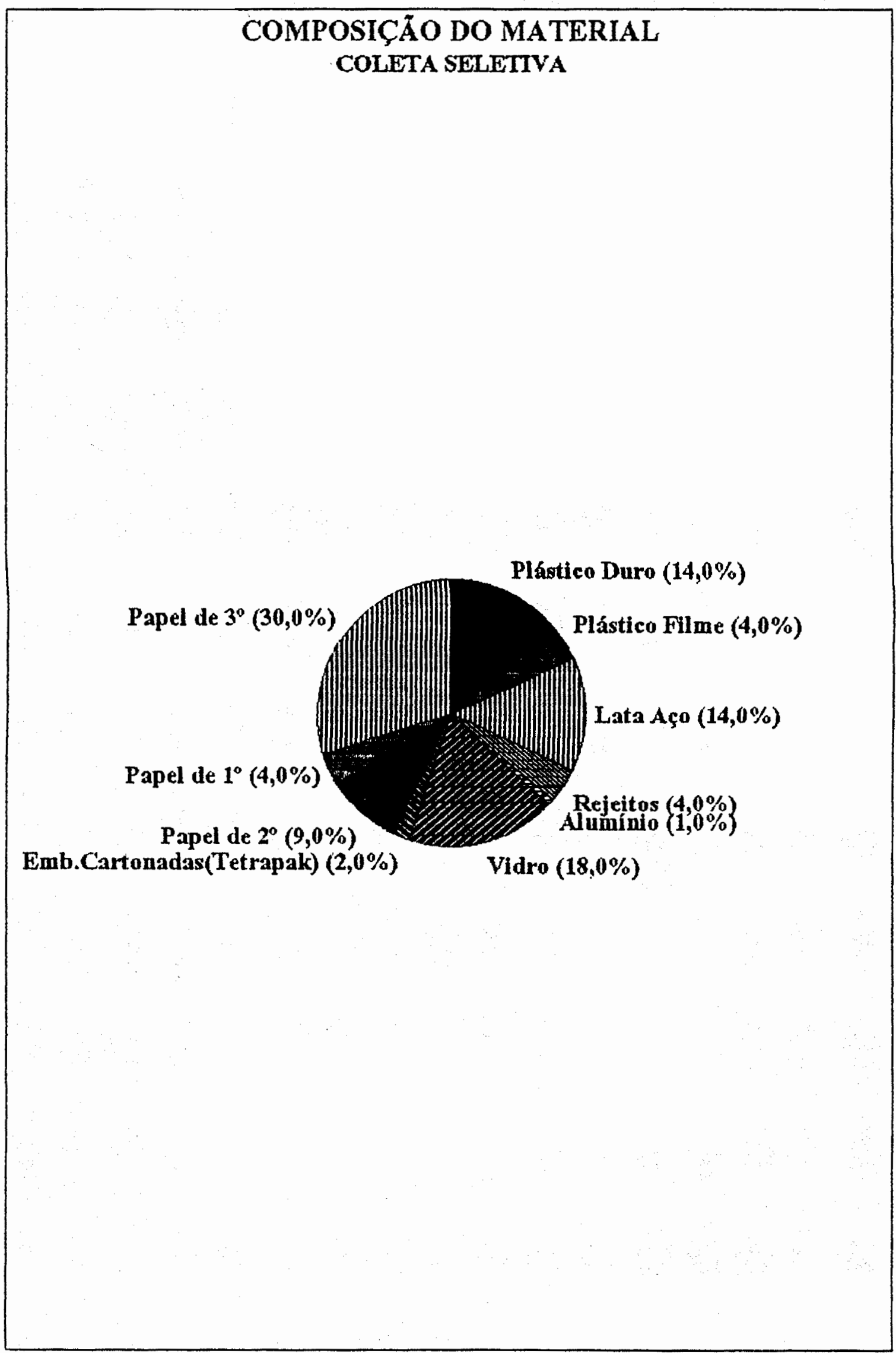


Saln 0 S

administração democrática popular

PREFEITURA MUNICIPAL DE SANTOS
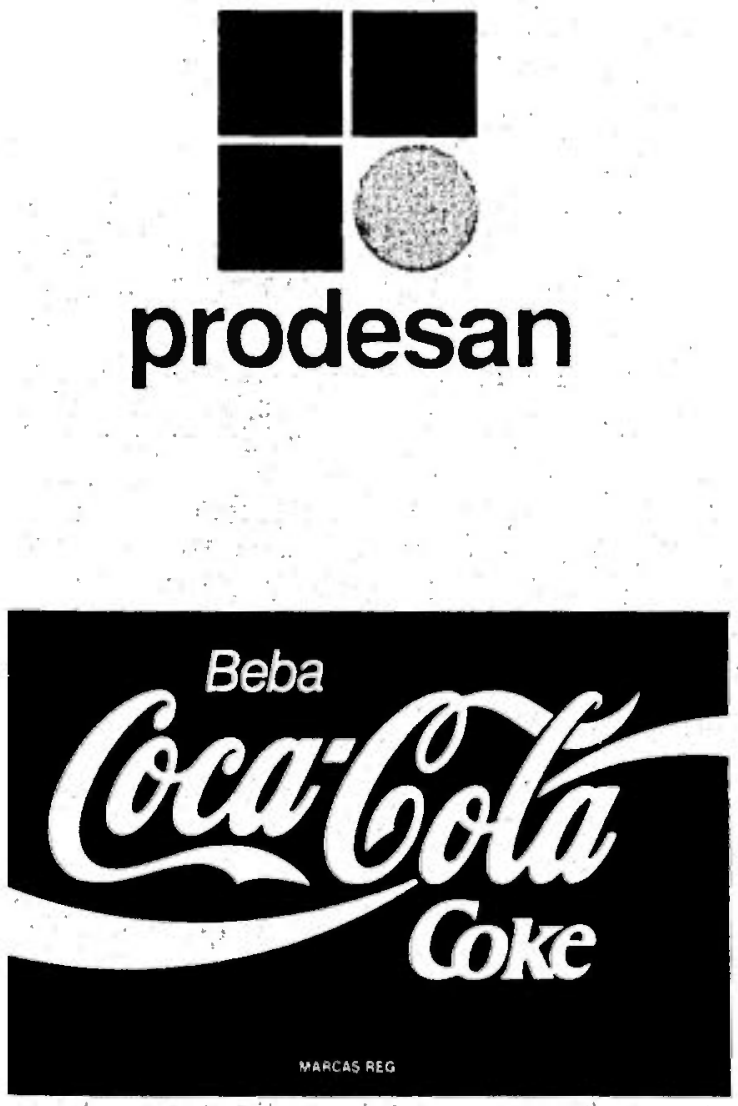

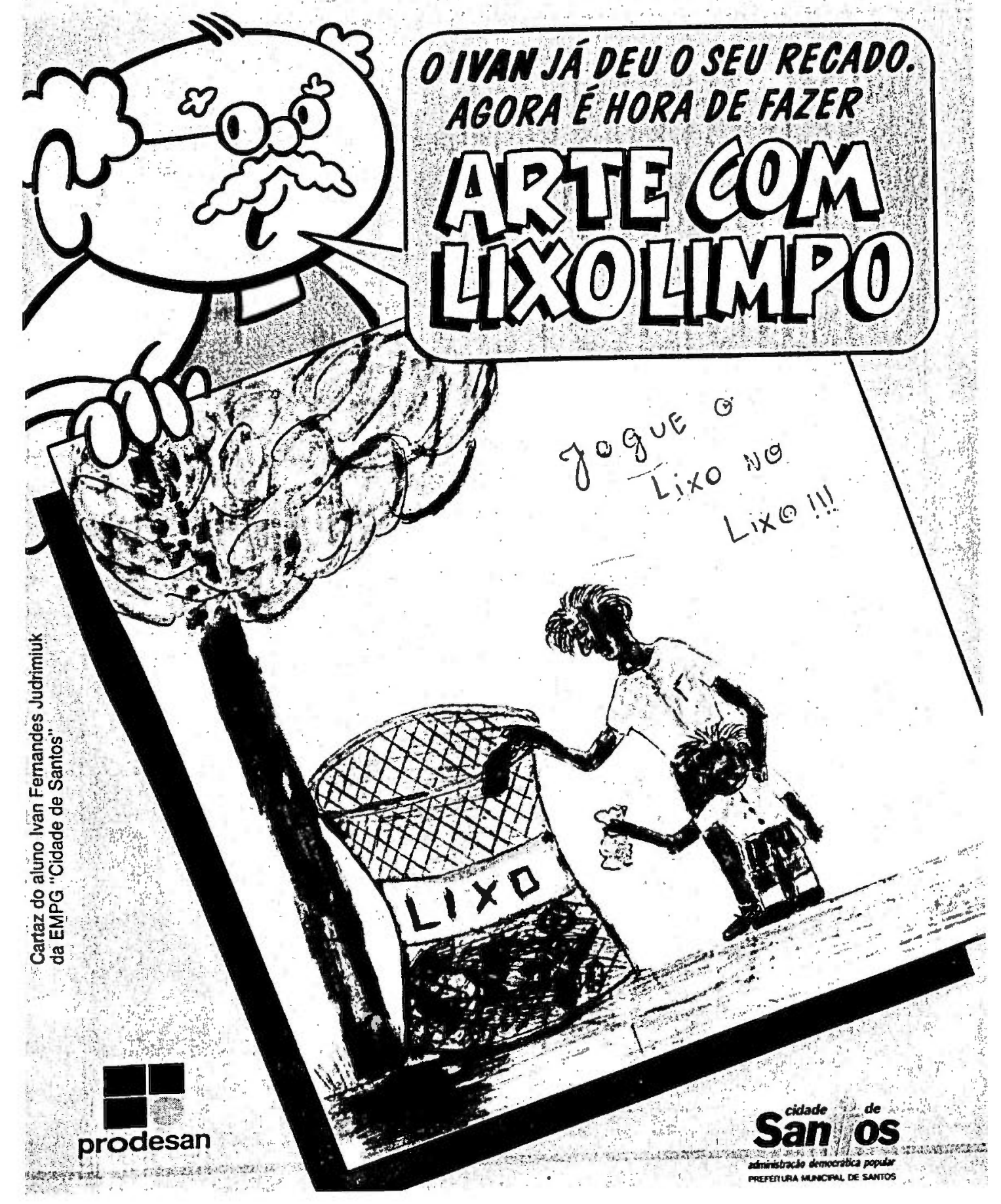




\section{Cx:

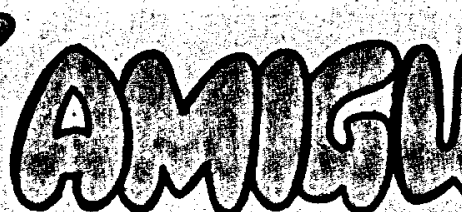

Você se lembra de mim, nãoé?

Eusou oSr.OLIMPOetenhoumanovidade superlegal. Em dezembrovaiaconteceraexposição "LIXOLIMPO". Seráno Sindicato dos Empregados da Administração Portuária e você pode participar com seu trabalho, para todo mundo ver.

Ésó fazer uma coisa bem bonita, usando plástico, vidro, papel e metal que a mamãe usou e vaijogar fora. Aí, é só entregar para sua professora até o dia 04 de dezembro. Quando começar a exposição "LIXO LIMPO", o seu

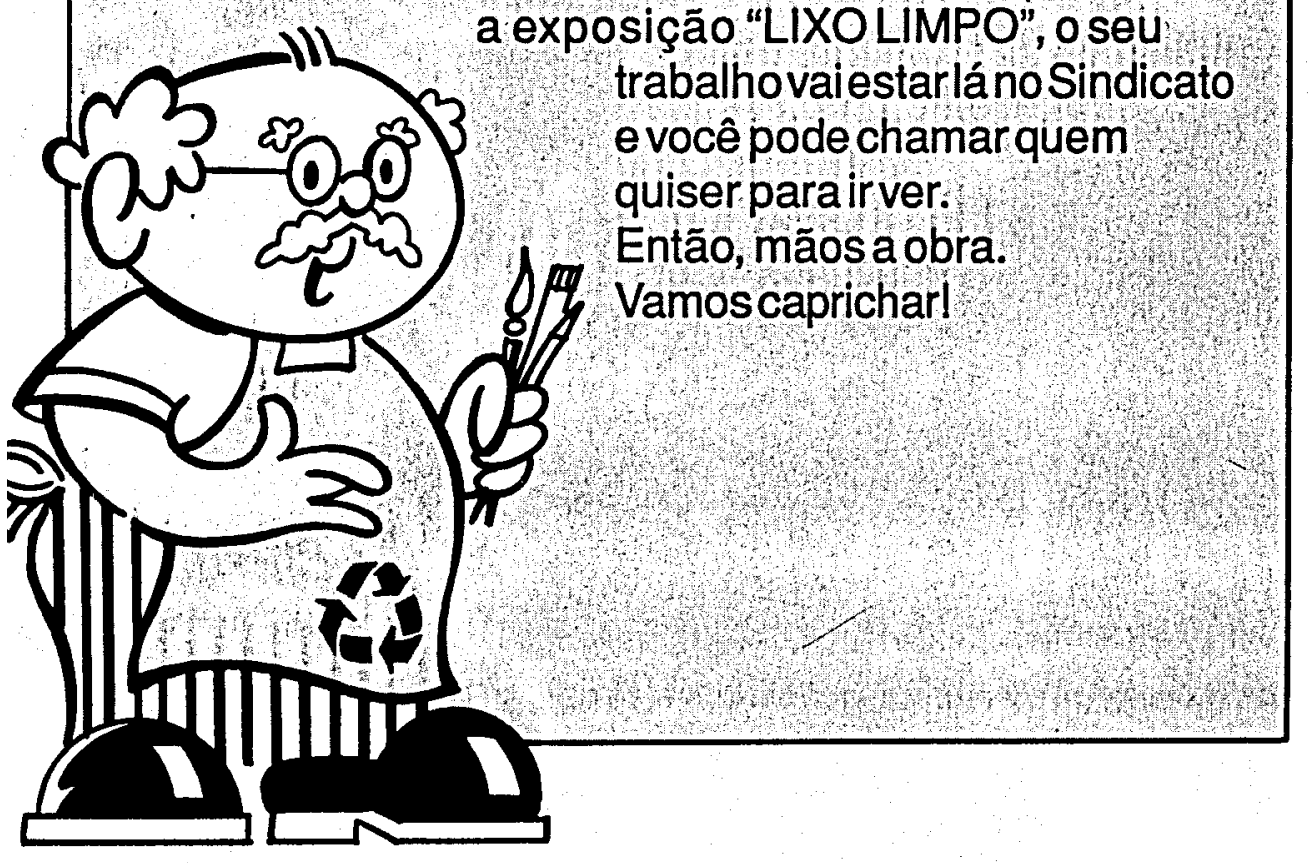

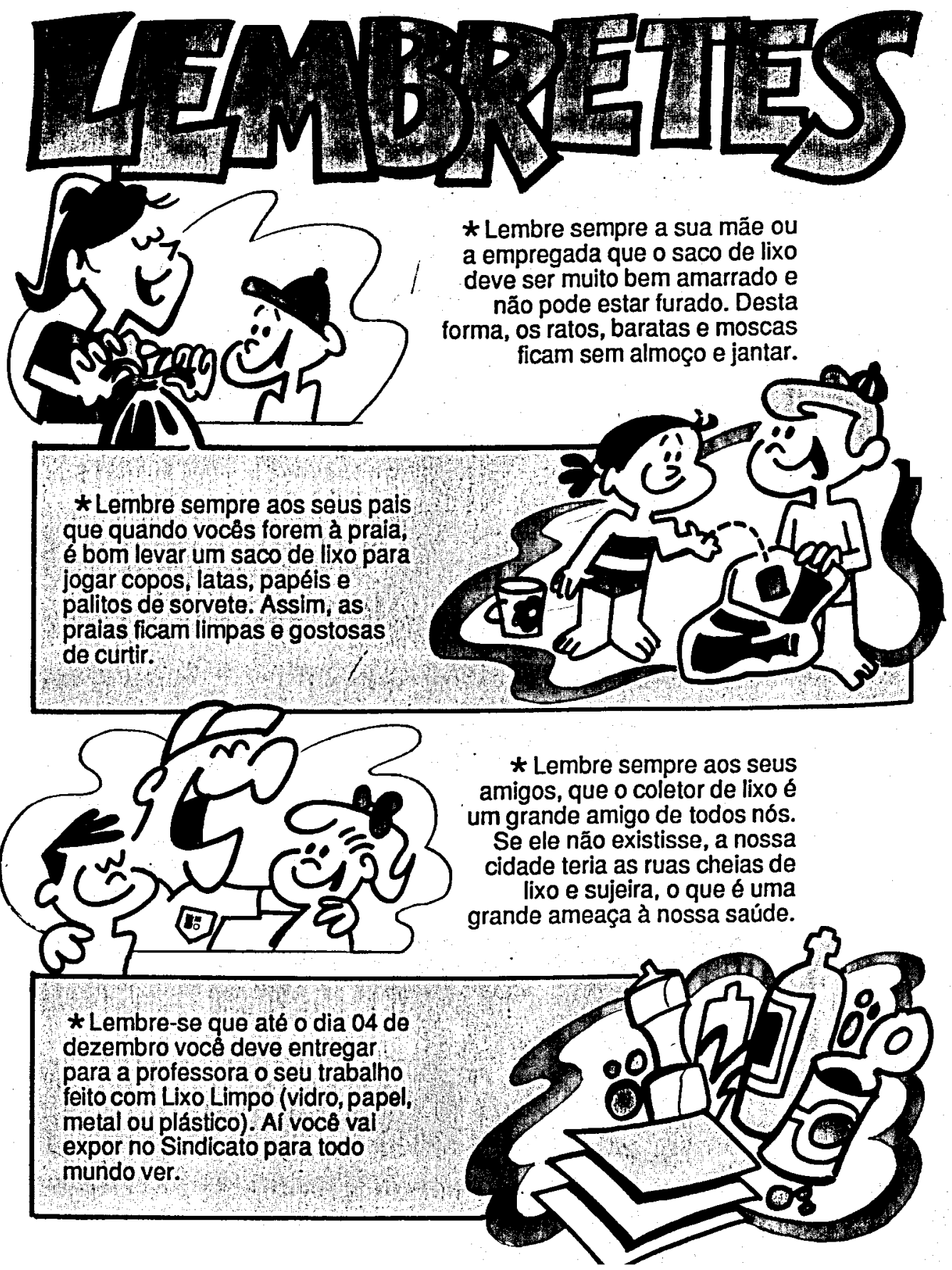



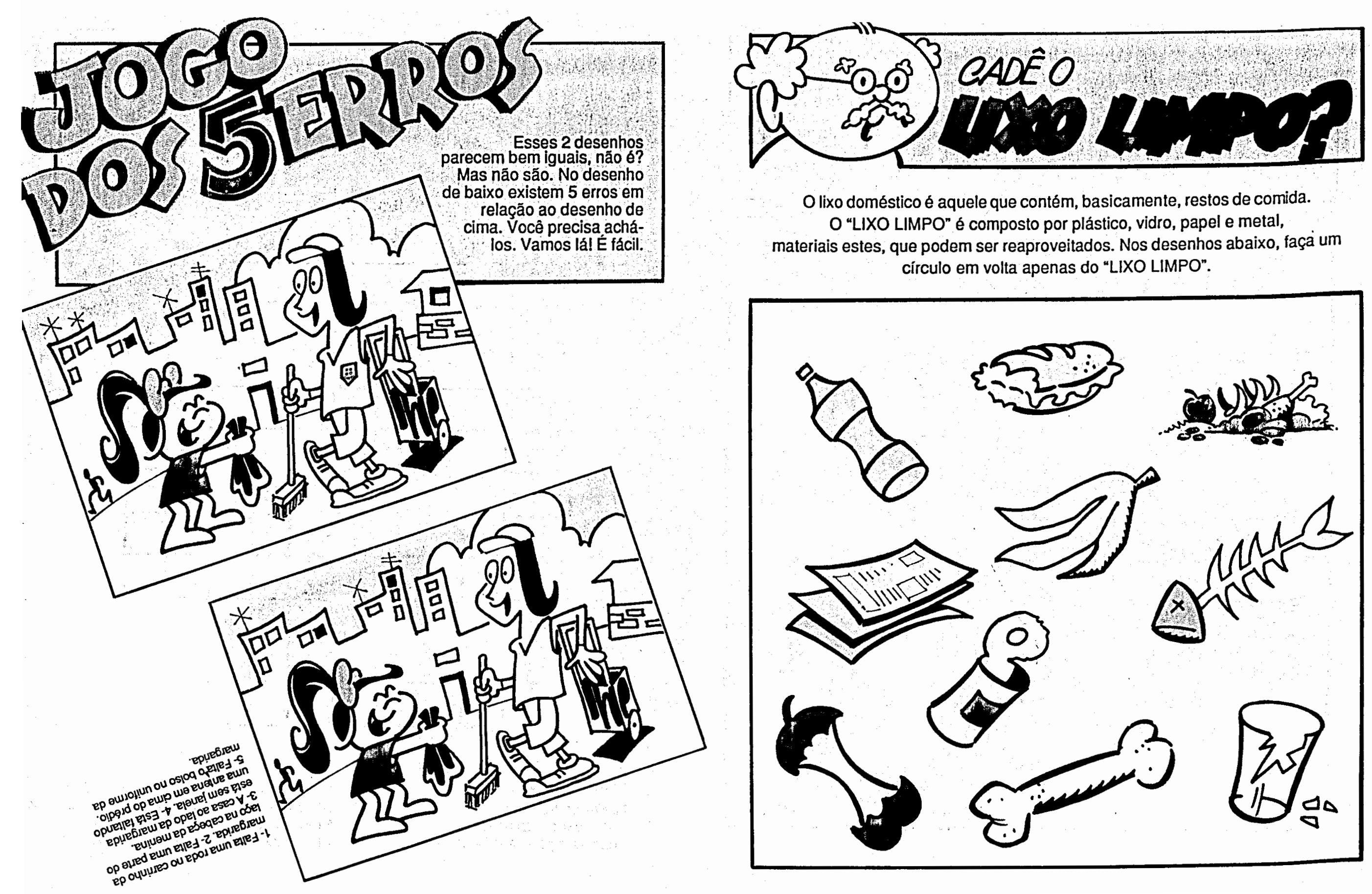

O lixo doméstico é aquele que contém, basicamente, restos de comida. O "LIXO LIMPO" é composto por plástico, vidro, papel e metal, materiais estes, que podem ser reaproveitados. Nos desenhos abaixo, faça um círculo em volta apenas do "LIXO LIMPO".

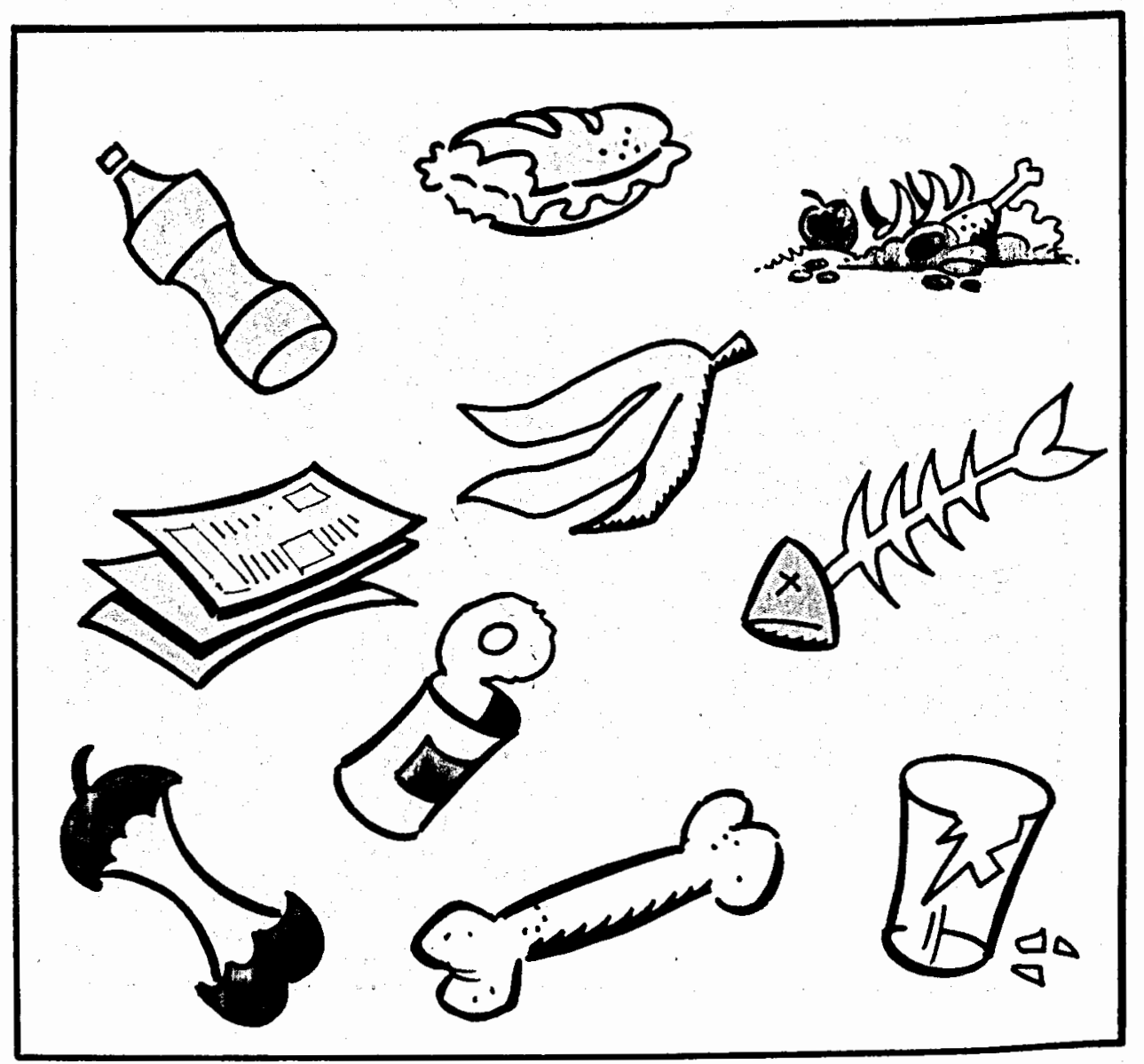



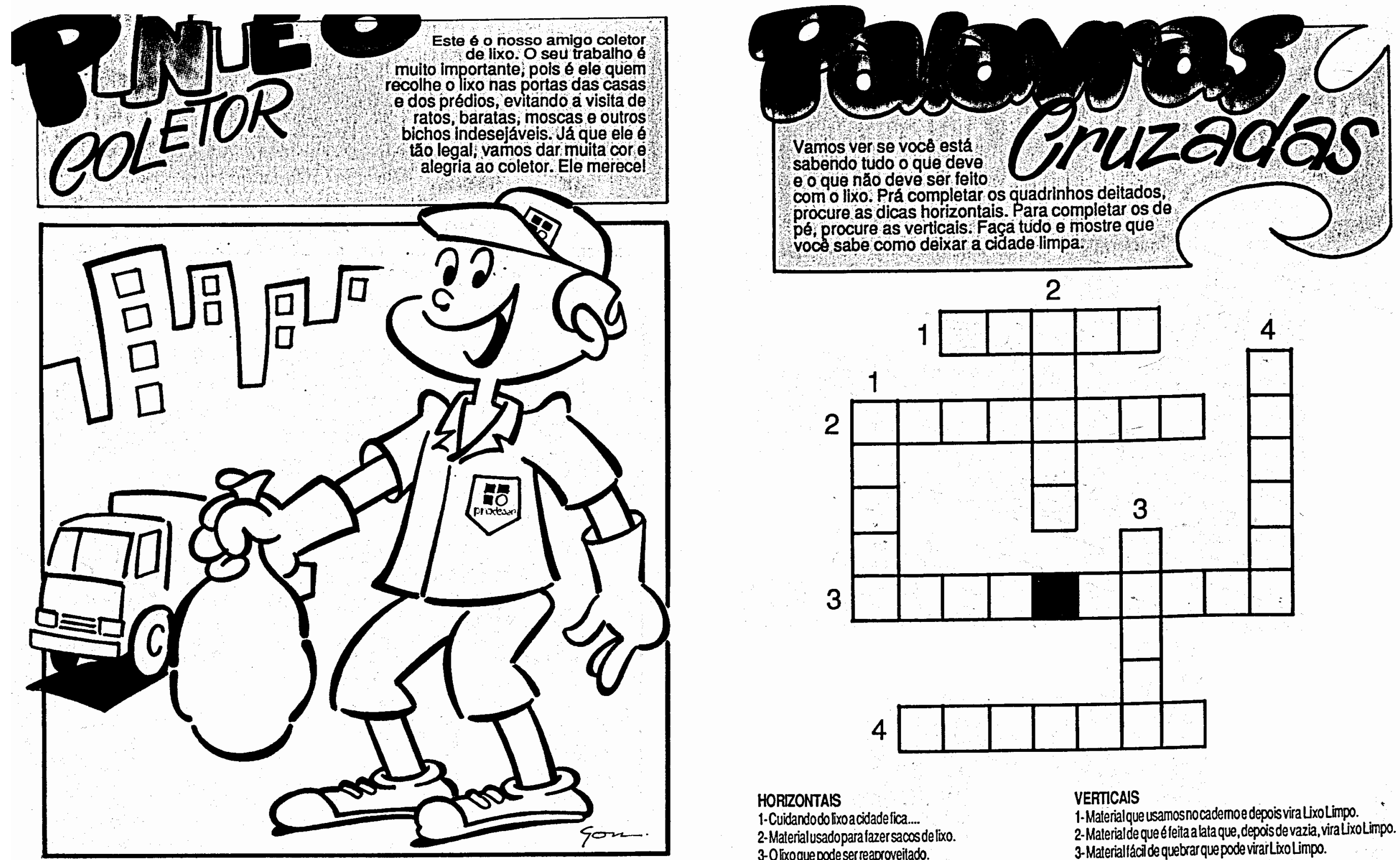

HORIZONTALS

1. Cuidandodo lixoacidade fica...

2-Materialusadoparafazersacos de lixo.

3-Olxoque pode serreaproveilado.

4. Onossoamigoquepassarecolhendolixo.
VERTICAIS

1-Material que usamosnocademoe depoisvira Lixo Limpo.

2-Malerial de queéfeitla alata que, depois de vazia, vira LixoLimpo.

3-Materiallfacilde quebrar que pode virar Lixo Limpo.

4 Nomedaquele senhorsimpático que adoralimpeza. 


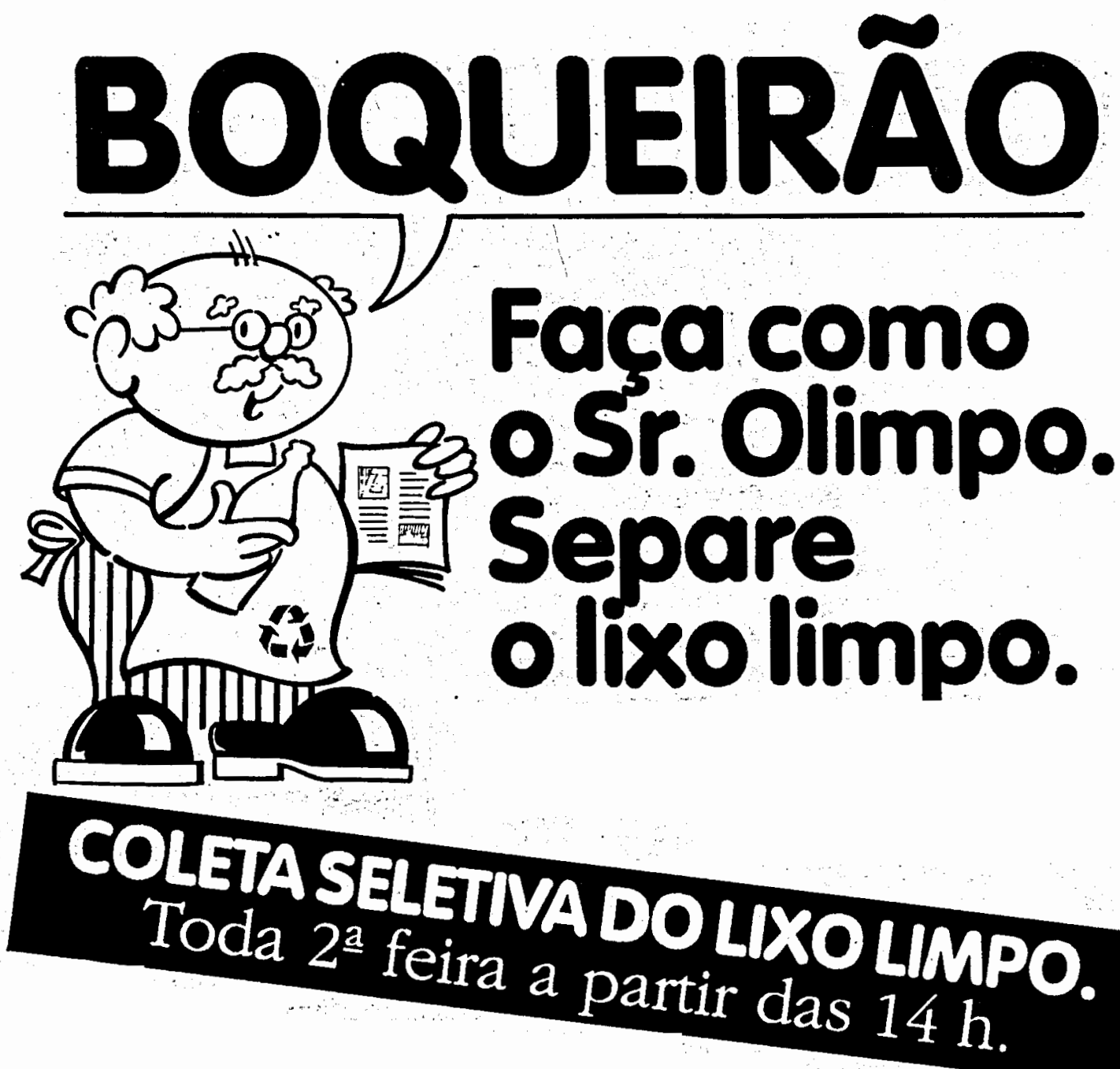

MATERIAL RECICLÁVEL

VDRO PAPEL PLÁSTICO METAL

Garrafas, fras- Jornais, revis- Garrafas plásti- Latas, tubos de cos, cacos de tas, papéis, cas, embala- pasta de dente, vidro, etc. papelão, gens, frascos, tampinhas, etc. sacos, etc. potes, etc.

\section{Começa no dia 5 de agosto.}




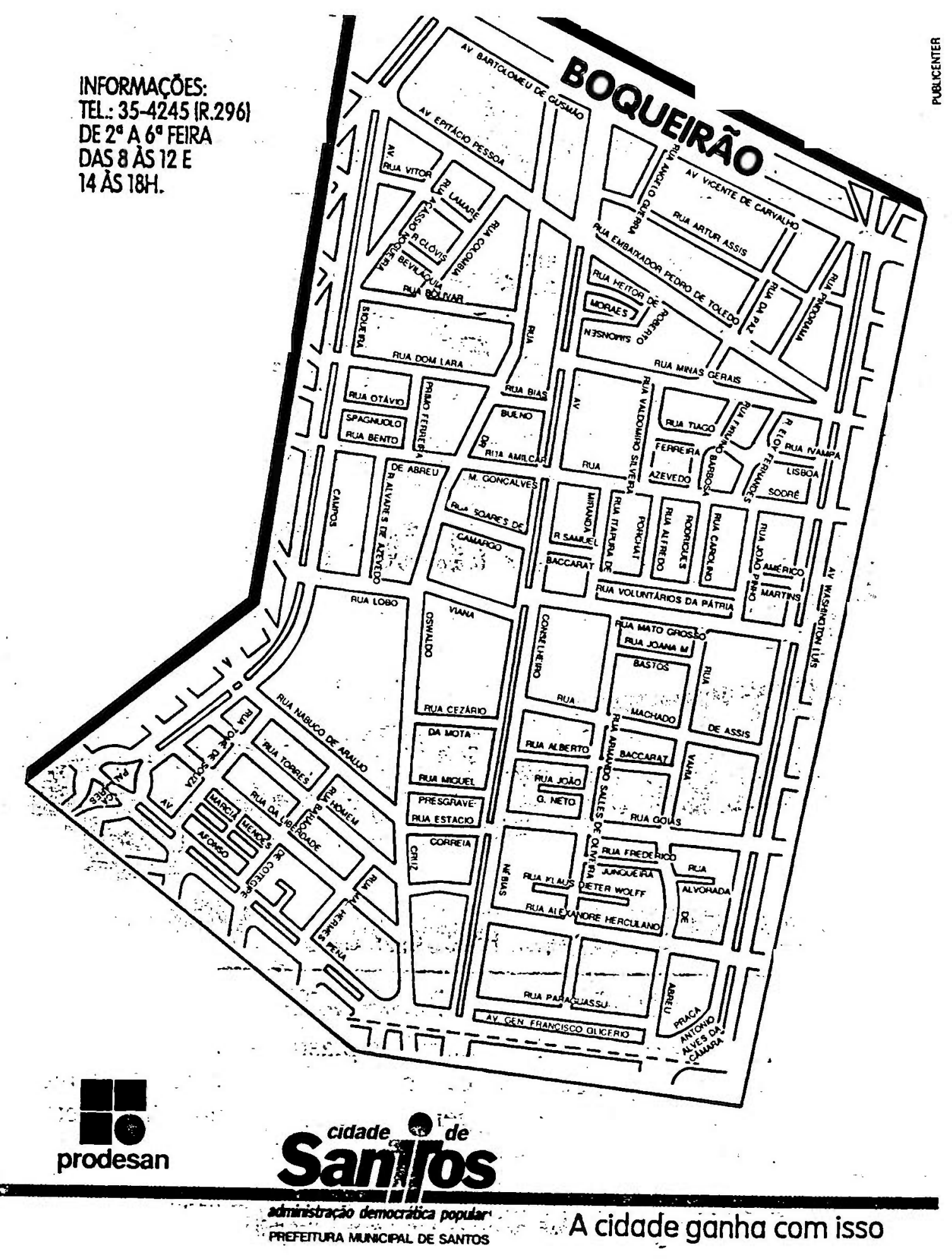



estava ma por condicionado.

Antes de embalar o lixo separe aquele considerado lixo orgânico (restos de alimentos) do lixo limpo (plástico, vidro, papel e metal). Observe os dias da coleta especial do lixo limpo em seu bairro, anunciado através do toque de um sino no caminhão e entregue-o a um dos coletores.

Embrulhe as garrafas, cacos de vidro e de loupas e latas, com papelão ou
bastante jornal;

PRODESAN

SEAC - Secretaria da Ação Comunitária - PMS

SEDUC - Núcleo de Educação Ambiental - PMS

SEDAM - Secretaria de Desenvolvimento e Meio

Ambiente - PMS

SEAB - Secretaria de Abastecimento - PMS

SEHIG - Secretaria de Higiene e Saúde - PMS

SEOSP - Secretaria de Obras e Serviços Públicos - PMS

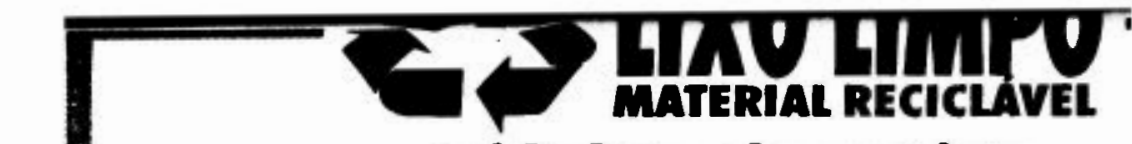 \\ A cidade ganha com isso.}

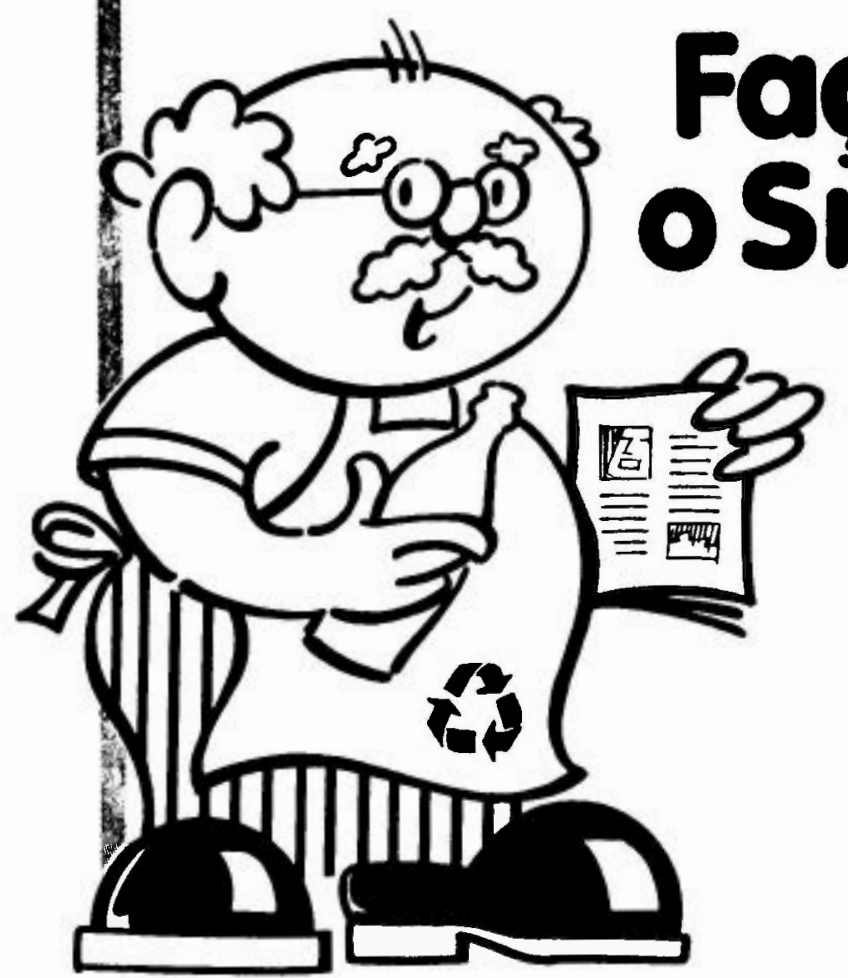

como como Olimpo Separe (0) ใी० 00

\section{Leia este manual e participe}

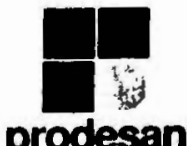

集

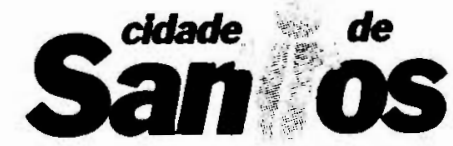

animistracisio democrattica popular PREFETTURA MUNICIPAL DE SANTOS 


\section{PREZADO MUNICIPE,}

Nem todo lixo é lixo. Você já pensou que muita coisa que é jogada fora diariamente pode ser reaproveitada?

Pensando no desperdício que ocorre com os materiais que se perdem, a Prefeitura Municipal de Santos está desenvolvendo na cidade o Programa "LIXO LIMPO". Trata-se da coleta seletiva do lixo limpo: vidros, plásticos, papéis, latas, jornais, etc., feita em dias previamente programados.

Com isso teremos uma série de benefícios, como:

- mais espaço para o depósito de lixo orgânico que, semo "LIXO LIMPO", poderá ser menor e melhor controlado;

- redução da extração de matéria prima, cada vez mais escassa na natureza;

- melhoria da qualidade de vida, com a redução da poluição ambiental;

A partir de agora, você não precisa sair de casa para defender o meio ambiente. Melhore, pois, a sua vida, cuidando do lixo. Isso vale uma vida melhor para todos nós.
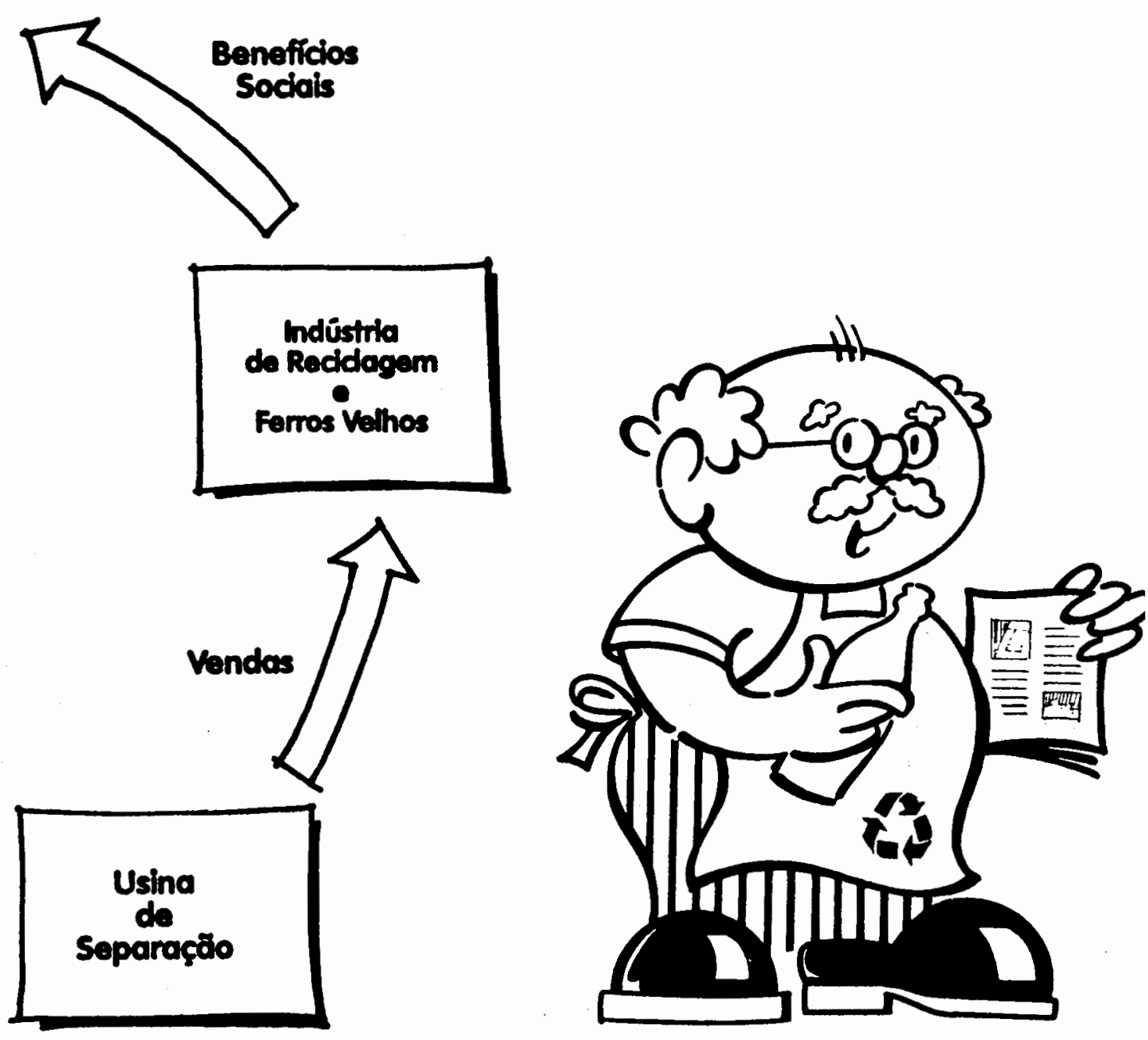


\section{Sugestōes para os predios.}

Se você mora em apartamento combine com os moradores a maneira de recolher o Lixo Limpo.

Faça uma reunião com os condôminos e o síndico para estabelecer um dia certo para a coleta.

Escolha um lugar apropriado no seu edifício para guardar o Lixo Limpo até o dia da passagem do caminhão. Caso não exista um local para isso, marque um horário para que o zelador ou o faxineiro recolha o Lixo Limpo nos apartamentos. Assim não haverá perigo de perder a hora e acumular desnecessariamente mais Lixo Limpo. Pará que nenhum dos moradores esqueça, procure afixar em lugar bem visível, um cartazete com a data em que o seu bairro recebe a visita do caminhão coletor do Lixo Limpo. Isso vale uma vida melhor.

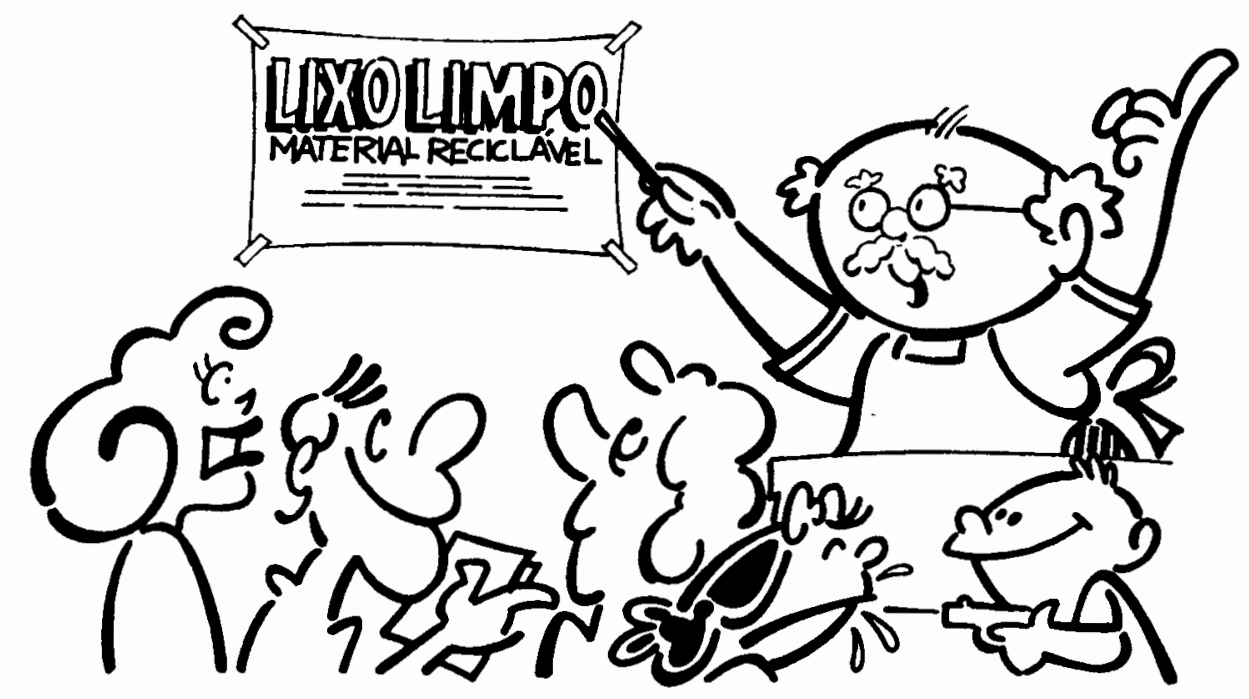

\section{Coleta seletiva do Lixo Limpo.}

Fique de ouvidos bem atentos. O caminhão da coleta seletiva do Lixo Limpo tocará um sino quando passar pelas ruas do seu bairro. Não perca a hora.

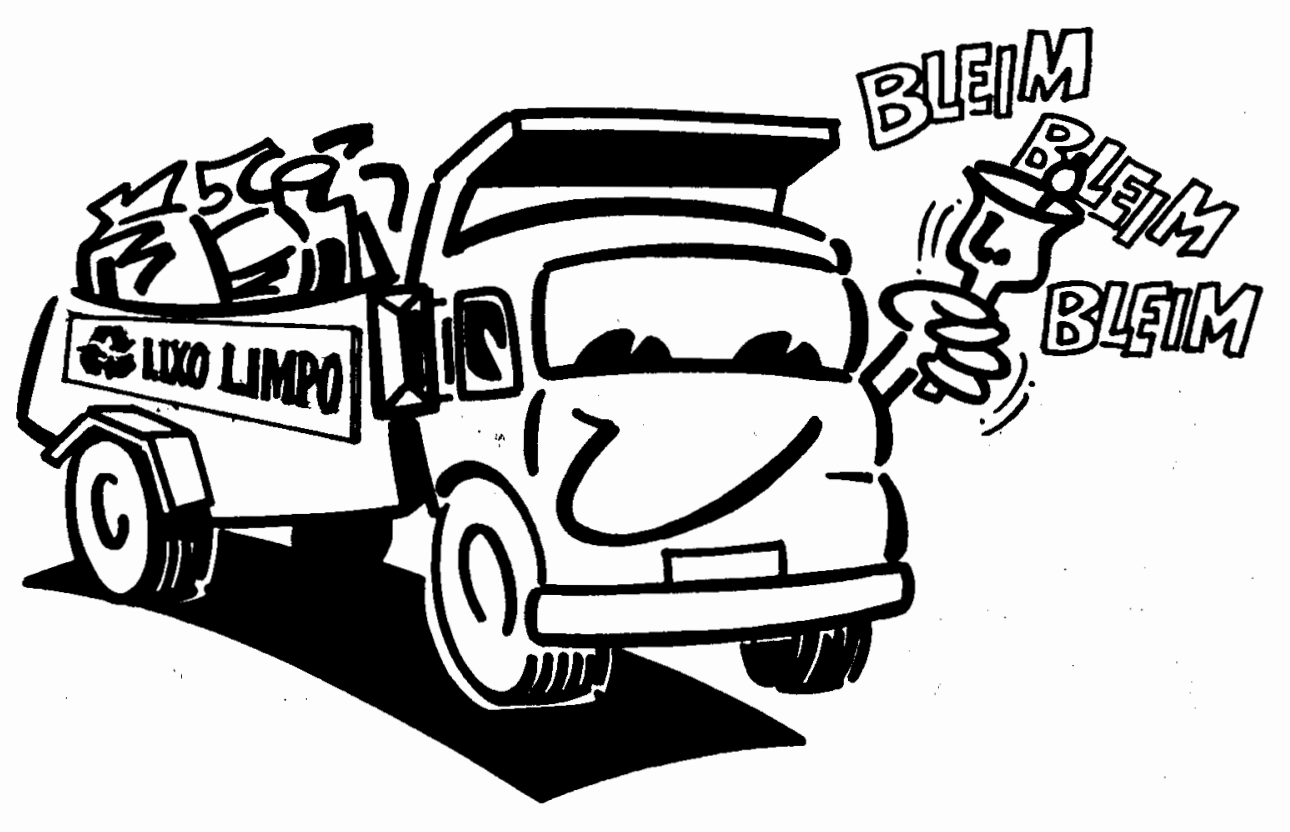




\section{Carrinheiros.}

Se você tem o costume de entregar o Lixo Limpo aos carrinheiros continue fazendo. O trabalho deles é muito importante e é o seu ganha pão.

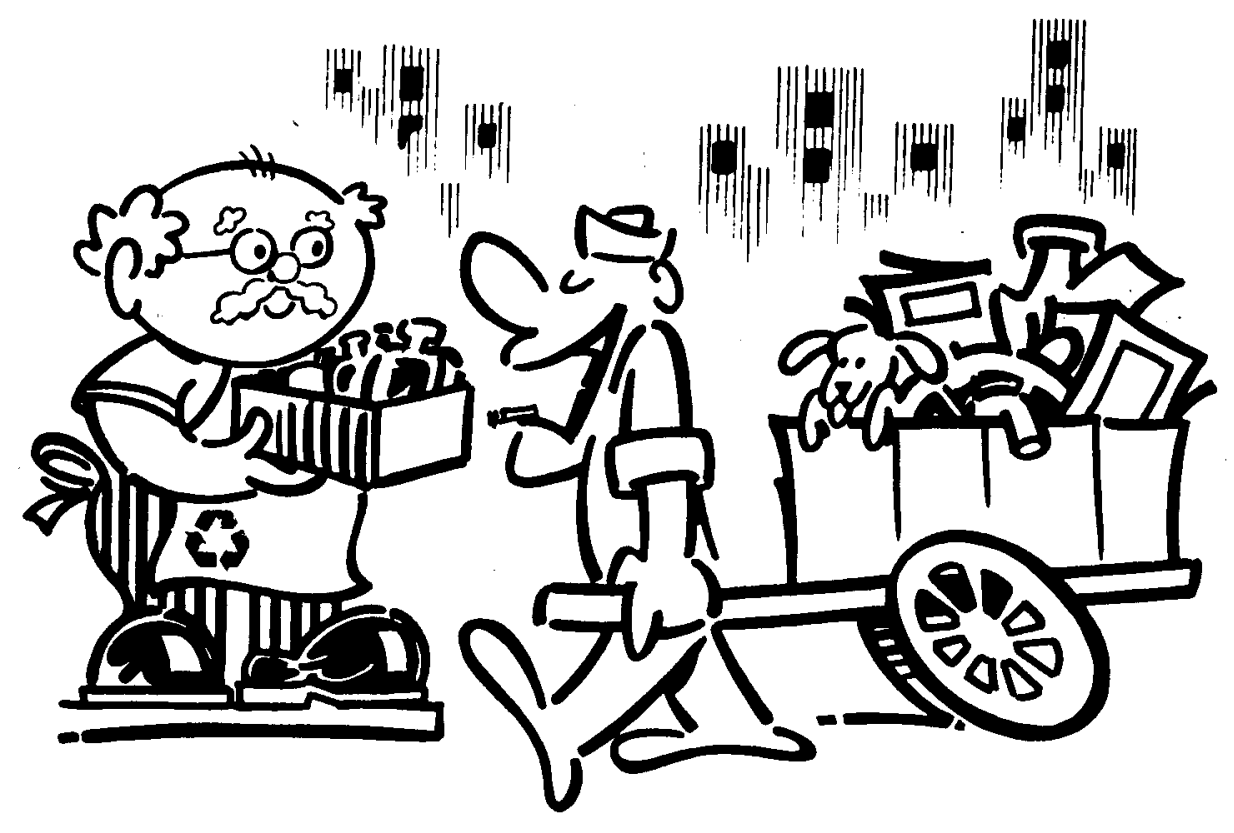

\section{Lixo orgânico.}

Agora que você já sabe o que chamamos de Lixo Limpo, preste atenção:

O lixo orgânico (restos de alimentos, lixo de banheiro, etc) deve ser separado do Lixo Limpo.

Acondicione o lixo orgânico em sacos plásticos e feche muito bem para evitar mau-cheiro, vazamento e ataque de animais. Horário de coleta do lixo orgânico.

A coleta do lixo orgânico em seu bairro continua sendo no mesmo horário e da mesma forma que antes. Observe o horário da passagem dos caminhões coletores, evitando que o lixo orgânico seja colocado muito antes ou depois da hora.

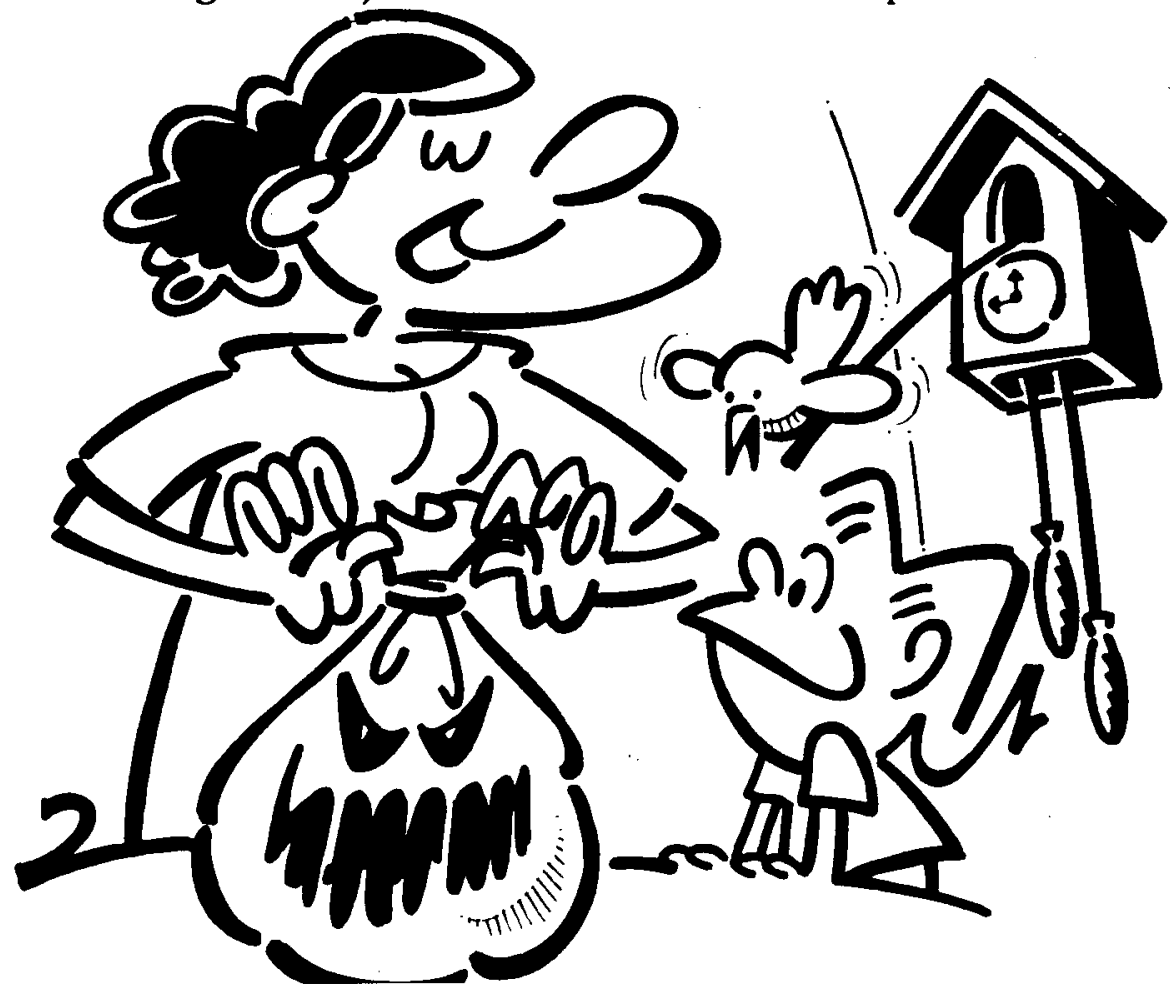


Veja o esquema da reciclagem.
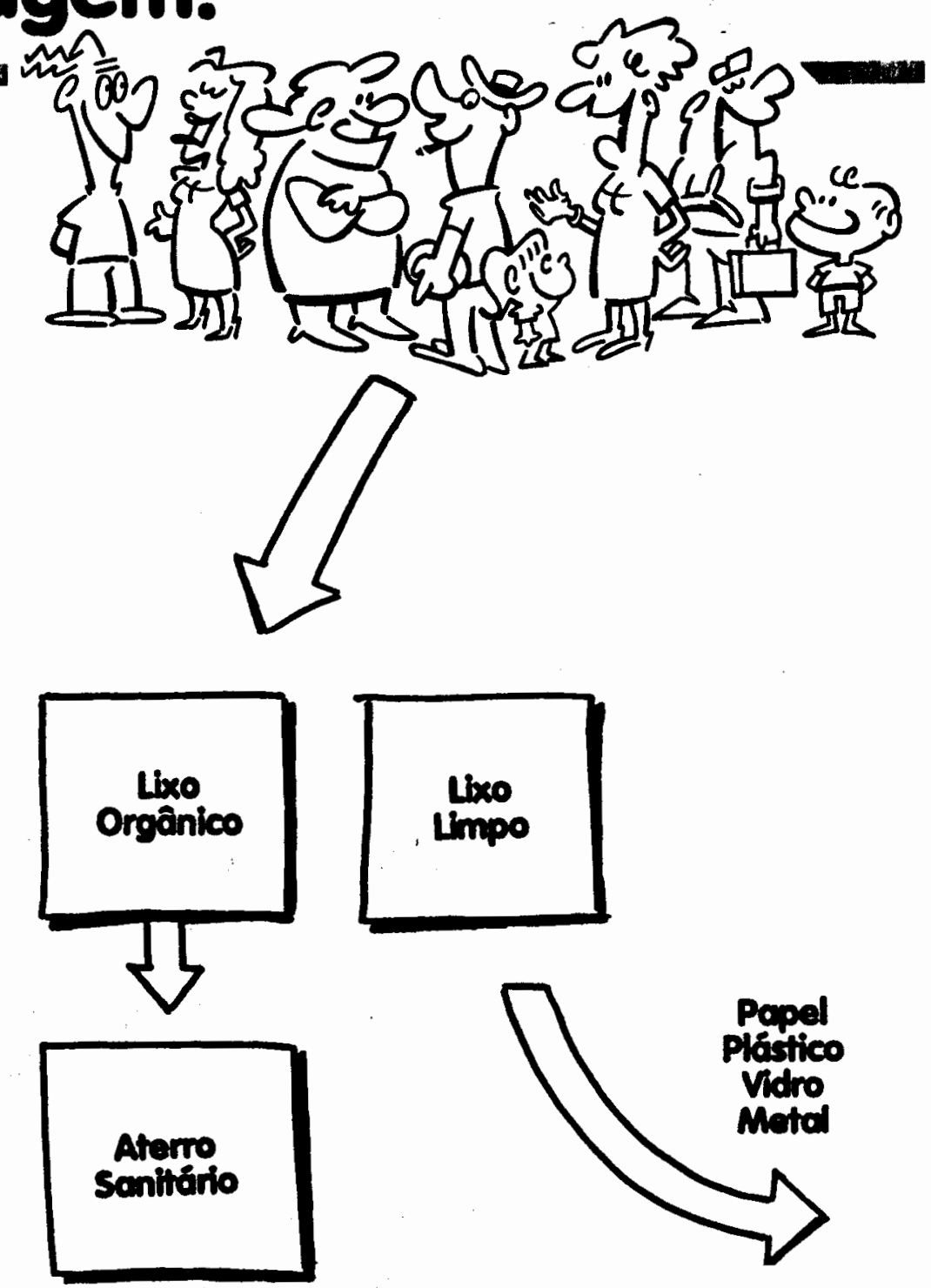

\section{Material reciclável.}

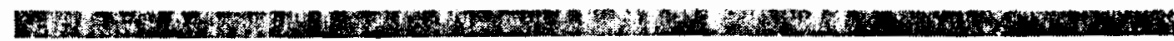

Todo Lixo Limpo deve ser colocado em sacos plásticos ou em caixas de papelão.

Veja alguns exemplos de Lixo Limpo:

- Vidro: garrafas, frascos, cacos de vidro, etc.

- Papel: jornais, revistas, papéis, papelão, sacos, etc.

- Plástico: garrafas, embalagens, frascos, potes, etc.

- Metal: latas, tubos de pasta, tampinhas, etc.

A seguir você verá como o Lixo Limpo é reaproveitado.

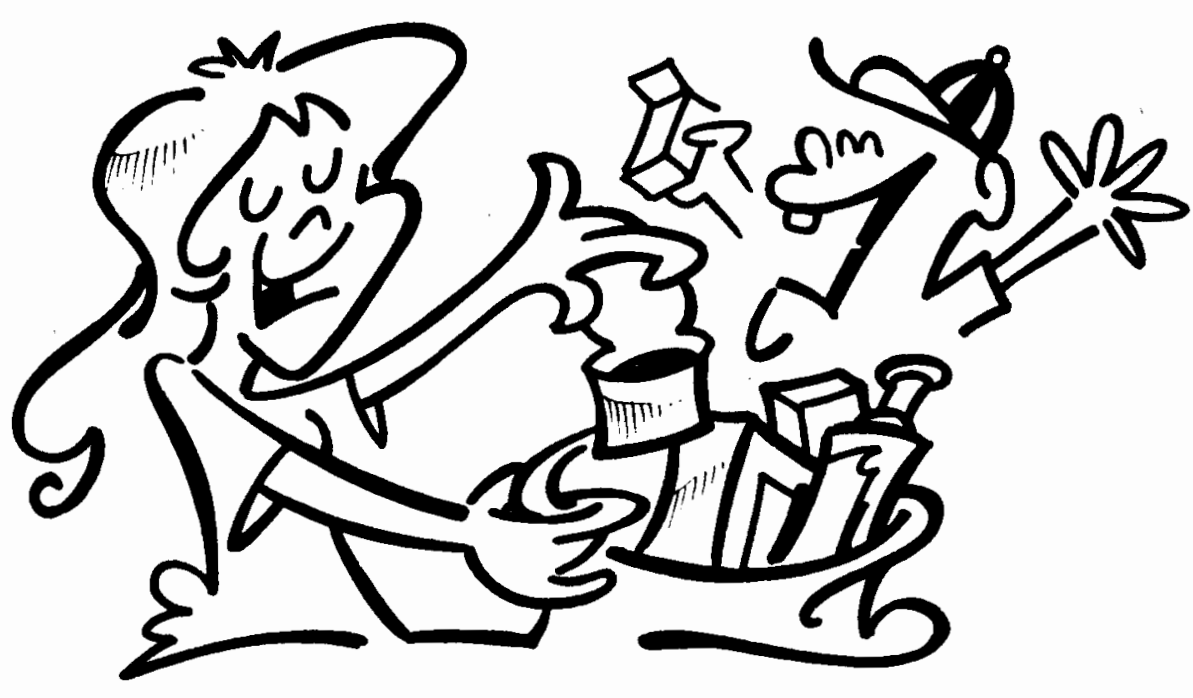


V.4. A EXPERIENCIA DA PREFEITURA DE SÃo PAULO

o Programa de Coleta Seletiva de São Paulo teve inicio em 1988. quando o então Secretário de Servicos e Obras de Sảo Paulo. Lucio Grégori. conheceu o projeto de coleta selet iva realizado em Niterói. no Estado do Rio de Janeiro, e se interessou em implantá-lo na cidade(35.57.61).

o bairro de Vila Madalena foi escolhido, com a participaçäo da comunidade e da Administração Regional de Pinheiros.Este bairro foi selecionado de acordo com a coordenacáo do proieto. por possuir certas características favoráveis. como populacão de classe média diferenciada com relacao às questioes em defesa do mein ambiente e considerada mais consciente do aue a média da populacáo( 35 ).

A partir de julho de 1988 foram organizadas reunióes com os representantes das comunidades envolvidas. moradores da Vila Madalena e representantes da Administradora Regional de Pinheiros(57.62).

o projeto teve boa repercussão entre a comunidade e. a partir desse retorno. foram feitas reformas na área do ant igo incinerador desativado de Pinheiros. visando a 
instalacáo do centro de triagem. Foi construido para este fim um galpáo. e pavimentada uma área de cerca de 1000 metros quadrados ( 57$).$

Foram selecionados ainda 4 caminhōes da frota normal, e treinadas 12 pessoas, e assim, com esta estrutura considerada quase rudimentar pela coordenacão, foi iniciado o projeto piloto em São Paulo(57).

Em 4 de julho de 1989 foi inaugurado oficialmente o proieto-piloto. com a entrega de sacos de papel para coleta porta-a-porta. além de folhetos explicativos e a realizacào de uma pesquisa com a comunidade envolvida.

Esse projeto piloto durou três meses e durante esse tempo os moradores continuaram a receber os sacos de papel para o recolhimento dos materiais separados (papéis, papelöes. vidros. metais e plasticosl. e a serem visitados para o aconpanhamento.

A participacảo dos moradores nesta fase 101 estimada em cerca de $70 \%$ a $80 \%$. coletando-se em média 5 loneladas semanais(tabela $9 /$ gráfico 1$)(35)$.

Com a interrupcäo da entrega dos sacos de papel. apos este periodo inicial. ocorreu uma pequena diminuicão do volume coletado. sendo observado que esta ocorreu principalmente nos predios de apartamentos. onde os funcionários responsaveis pela coleta nảo reconheciam os sacos com materiais reciclaveis. ja previamente selecionados. e estes. apesar de 
separados de forma adequada pelo morador. acabava sendo encaminhado para a coleta comum(02).

Mas o projeto continuou a contar com o apoio da populacáo. que se manifestava inclusive através da imprensa. crescendo a demanda de solicitacões de atendimento à outros bairros e condominios $(57)$.

Até maio de 1991 o Programa já havia sido ampliado para 10 circuitos abrangendo 24000 residências, envolvendo cerca de 117000 pessoas; até o final de junho foram inaugurados mais 9 circuitos levando a coleta porta-a-porta para mais 34000 novos domicílios. somando mais 170000 pessoas 102.57$)$.

Em maio de 1991 foi iniciado o projeto dos P.E.Vs - Postos de Entrega Voluntária, que consistiam em um coniunto de quatro coletores de cores diferentes (verde. azul. amarelo e vermelho 1 .onde a populacão depositava respectivamente vidros.papeis. netais e plásticos.

O ob.jetivo da instalacão dos P.E.Vs foi possibilitar a participacào daquela populacão que estava notivada. mas que náo era servida pelo circuito de coleta seletiva(61.35)

Estes coniuntos foram instalados em párques públicos. bibliotecas. "shoppings center". conjuntos habitacionais. no campus universitário da USP. etc. 
Até dezembro de 1992 tinham sido instalados 37 conjuntos desses coletores de 1500 litros cada. e eran ut 1 lizados 5 caminhoes de carroceria com equipamento tipo Munck. para a coleta(02).

Da mesma torma. até o final de 92, a coleta se expandiu para 33 circuitos, abrangendo 102000 domicílios com uma populacäo estimada de 510000 pessoas $(02.35)$.

Nesta época as 230 toneladas mensais(cerca de 10 toneladas/dia) provenientes do circuito de coleta domiciliar (75\%). PEVs (15\%), e doações espontâneas (10\%) eram encaminhadas para o Centro de Triagem de Pinheiros, onde procedia-se à separacão por cataçāo, o acondicionamento (prensagem. enfardamento ou trituração), e à comercializacão(02). A composicāo desse material encontra-se na figura 9.

Nessa época o Centro de Triagem contava com uma esteira de separacāo. com capacidade de até 20 toneladas/dia. prensas para papel.trituradores de vidro é de vlást ico(0)2).

Existiam planos para uma reforma. com a adaptacáo do antigo incinerador. localizado na mesma área para Centro de Triagem. com instalação de mais uma linha de separacăo em dois segmentos. além da instalação de mais uma esteira no galpáo existente. com alimentacāo por meio de um tosso. Estava prevista ainda a construcáo de infra-estrutura necessaria ao desenvolvimento do proieto (sede da administracào. 
auditórin. vestiários $1(35.57 .611$.

A mão de obra para a seleção dos materiais estava a cargo do Corpo Municipal de Voluntários (CMV). e a veriba arrecadada com a venda dos materiais. que pelo projeto inicial seria revertida ao bairro arrecadador. cobria somente os custos dessa mảo de obra do Centro de Triagem(35). 
Os circuitos eram escolhidos em conjunto com as Administracoes Regionais, procurando atingir os bairros mais organizados e com demanda para este tipo de ação (35). Em seguida eram realizadas reuniōes com moradores ou seus representantes. distribuidos folhetos explicativos(ver folhetos anexos. do município de São Paulol, de casa em casa, assim como quatro sacos de papel. suficientes para as quatro coletas semanais, relativas ao primeiro mês de implantacão.

A coleta era realizada uma vez por semana, em dia e período pré-determinados. A Divisão de F.ducacao e Divulgacáo do Departamento de Limpeza Urbana atendia e lornecia informacoes sobre os residuos urbanos. a todas as pessoas interessadas $(35)$.

Eram desenvolvidas palestras agendadas com antecedencia. mostravam-se audio-visuais. distribuiam-se lolhetos explicatıvos e tiravam-se as duvidas.

O atendimento às escolas era considerado preferencial. uma vez que para esta Divisão. era essencial a capacitacáo de professores e alunos. mas atendia-se tambér a 
urou wi Incais oncle haviam sido instalados PEVs e circuitos de coleta(35).

Normalmente o atendimento era feito na propria Divisào de Educacăo e. em casos especiais. as visitas às unidades de tratamento de lixo eram permitidas. Permitia-se também o uso do Centro de Documentacão aberto ao público para consultas e pesquisas $(02)$.

Com relacão ao material de divulgação utilizado em Sào Paulo. consistia de uma grande variedade de folhetos especificos para os diversos públicos a serem atendidos Ipopulacảo em geral. escolas. condomínios. potenciais usuários de PEVs e moradores de bairros com circuito de coleta seletiva (ver folhetos anexos. do município de São Paulo).

A maior parte deles continha grande quantidade de informacooes. destacando o total de resíduos gerados na cidade de São Paulo por dia. as vantagens da reciclagem para cada tipo de material. e indicacōes de como a populacao paderia participar em cada caso específico (coleta porta a porta. PEVs, escolas, condomínios).

Fazia parte do Projeto. a assistência às iniciativas espontaneas de coleta seletiva em condominios. clubes e enpresas. e eram fornecidos material explicativo e orientacies sobre coleta. comercializacáo e listagem de sucateiros em atividade por região. 
Era realizada também coleta seletiva interna de papéis nas dependèncias da LIMPURB. órgão responsável Nela inplantacáo do programa. e existia a proposta de expansão desta para todos os órgáos municipais. assim como o uso de papel reciclado nestas reparticões públicas $(35)$. 


\section{CICLO DO METAL}

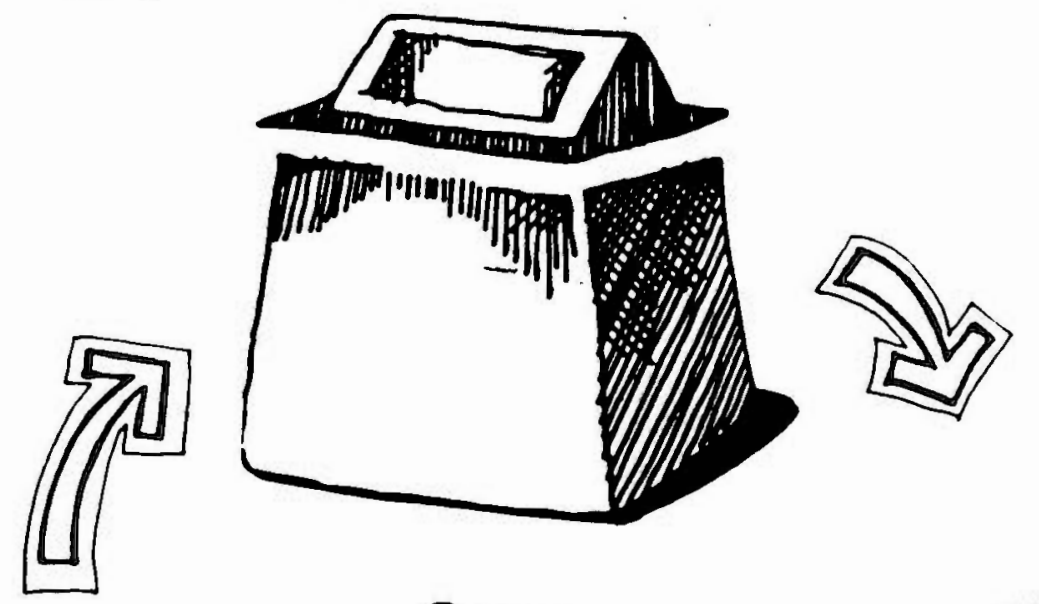

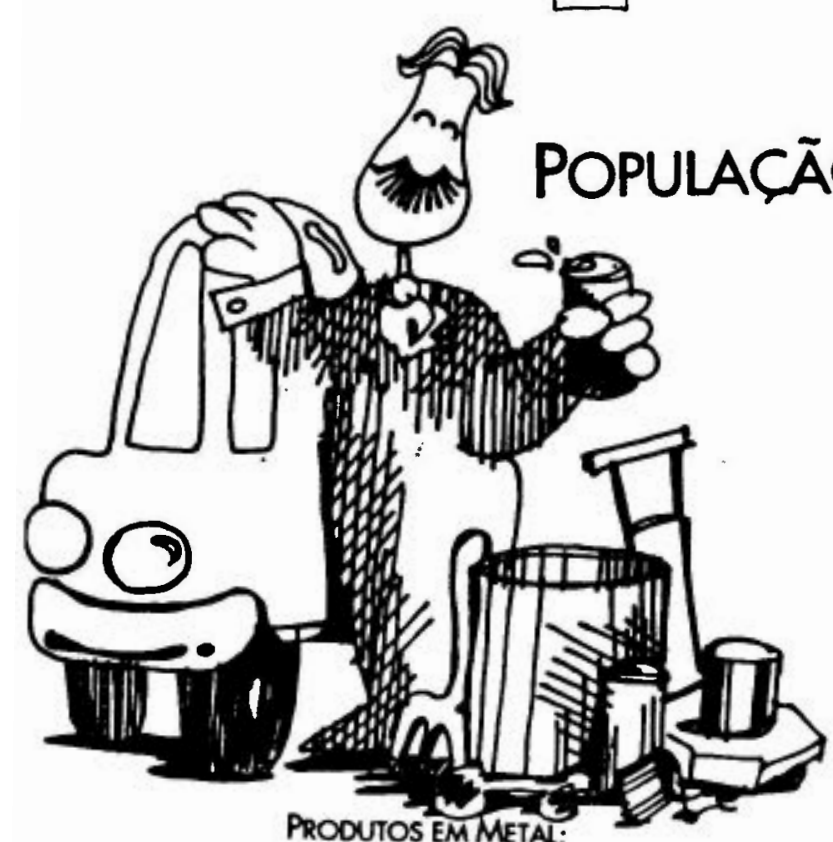

LATAS DE REFRIGERANTE, CERVEJA (ALUMINHO) E DE ALUENTIOS, TINTAS (FOMAA-DE-FLANDRES/ AÇO), OBJETOS METAUKCOS,...
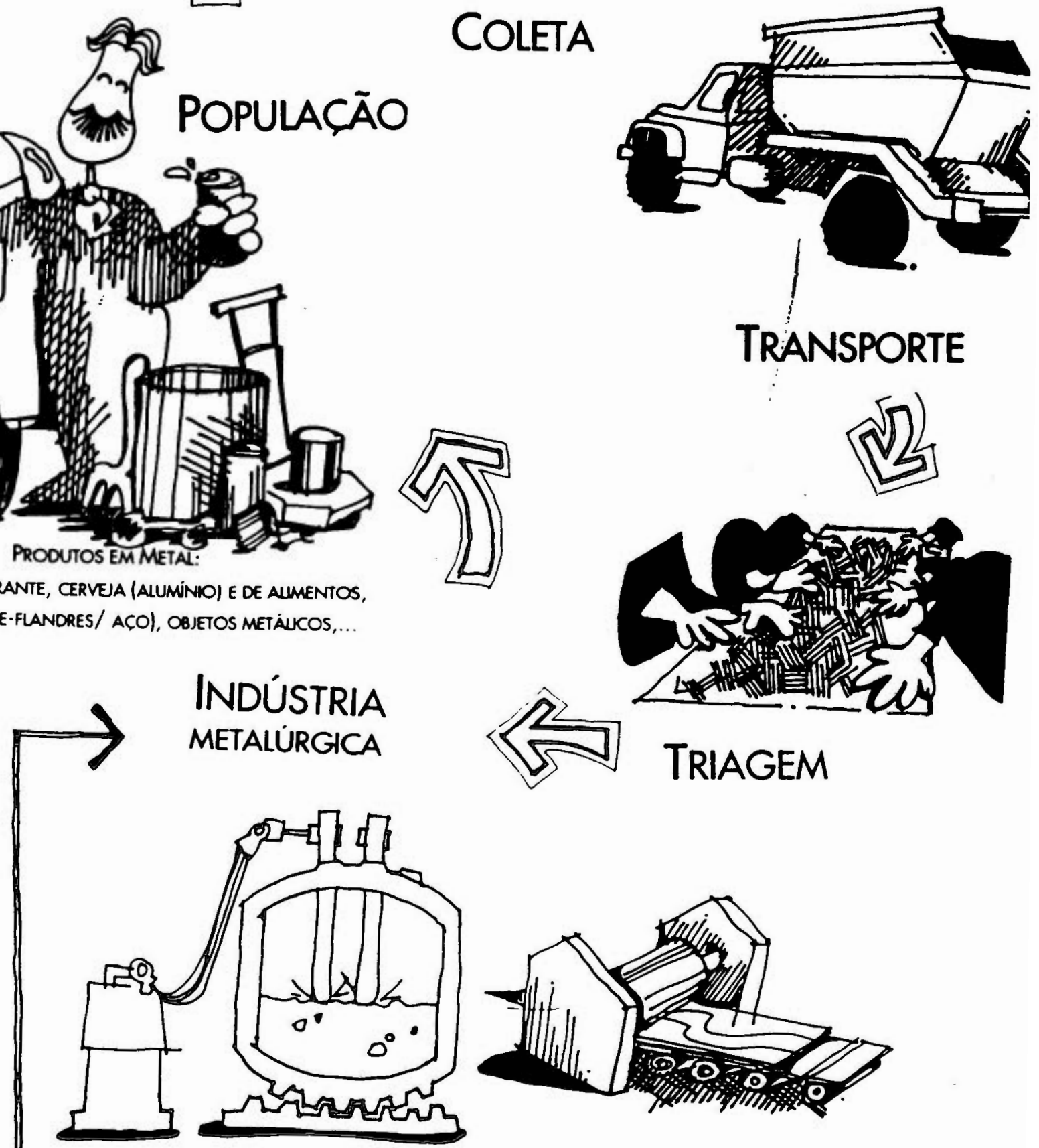

Refusāo $\Longrightarrow$ fabricação de Chapas metállcas 
FIGURA 9 - SÃO PAULO

\section{COMPOSIÇÃO DO MATERIAL COLETA SELETIVA}

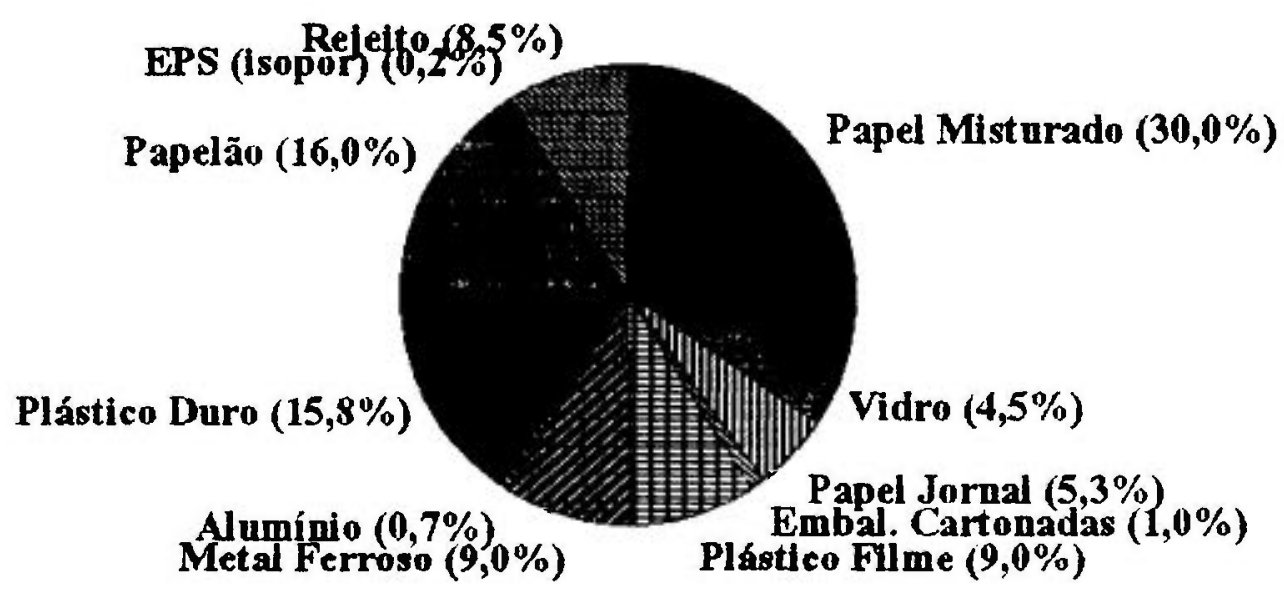




\section{COLETA SE EFFTHA DE LXO}

EDITADO PELA LIMPURB - № 01

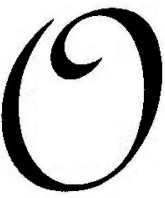

PROJETO AVANCEA. ACOMPANHE DE PERTO.

A Coleta Seletiva de Lixo existe

há muito tempo nos países

desenvolvidos. Lá as pessoas já estão acostumadas a separar e levar para os recipientes seletivos aquilo que pode ser matéria-prima para novos produtos. A cidade de São Paulo possui, porém, algo que poucos países têm: a Coleta Domiciliar em alguns bairros. Hoje já são 32 circuitos que totalizam 86.117 domicílios. Um deles é o seu! Você goza de um privilégio que poucos na cidade têm. O caminhão da Coleta Seletiva passa semanalmente na porta de sua casa!

Desde 1989 a Prefeitura de São Paulo vem implantando o Programa de Coleta Seletiva na cidade. Essa coleta recolhe o lixo reciclável que as pessoas separam nas casas e escritórios: papéis, metais, plásticos e vidros. Além dos 32 circuitos, existem ainda 24 Postos de Entrega Voluntária. O material recolhido é levado ao Centro de Triagem de Pinheiros, onde o lixo reciclável é separado por tipos e vendido para as indústrias recicladoras

Apesar da crise, o lixo paulistano é um dos mais ricos do mundo. Por quê? Veja só:
A população está acostumada ao desperdício, jogando fora materiais recicláveis. Isto faz com que o volume do nosso lixo seja muito maior do que deveria ser! E acabamos pagando caro pela remoção das quase 12 mil toneladas diárias de lixo que geramos para os aterros sanitários, onde o lixo é enterrado misturado a valiosos materiais. O problema do lixo é de todos nós, que pagamos uma taxa de limpeza urbana nos impostos municipais. O objetivo da Coleta Seletiva é ensinar a população a gerenciar o lixo que ela mesma produz, diminuir o prejuízo da cidade com a destinação do lixo e economizar espaço nos aterros sanitários, um espaço que é limitado e que está cada vez mais difícil de encontrar.

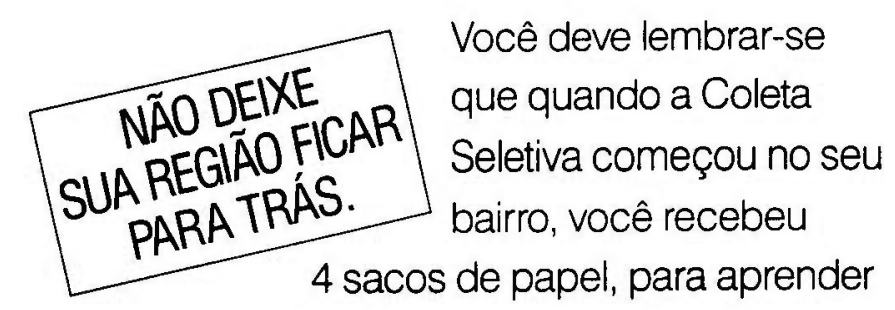

a separar o lixo. Só que muita gente achou que precisava receber os sacos para participar, e depois do primeiro mês esqueceu-se completamente da Coleta Seletiva.

Você pode separar o seu lixo seletivo em qualquer saco! E o caminhão continua a passar toda semana. Existem circuitos onde a população simplesmente se esqueceu de que 
há Coleta Seletiva passando na porta. Eela está pagando, e caro, para que os caminhões voltem vazios do seu bairro... E isso enquanto outros bairros estão pedindo a Coleta Seletiva sem poder ser atendidos! Como é que a Prefeitura define esses circuitos? A escolha é feita a partir dos pedidos de moradores encaminhados às suas Administrações Regionais. A Regional analisa a viabilidade do pedido. Quanto mais organizado um bairro ou quarteirão, maior a probabilidade de conseguir a Coleta Seletiva na sua porta.

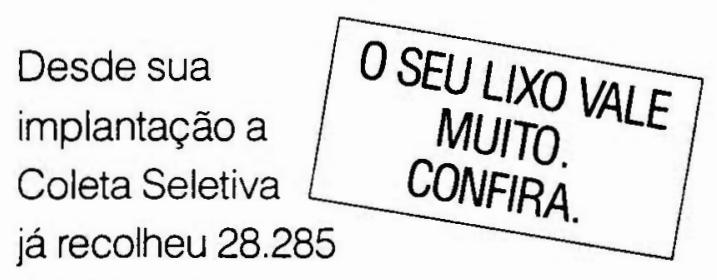

toneladas de material reciclável. O que isto significa? Veja só: As 1289 toneladas de papel recolhido correspondem a uma economia de 25.781 árvores adultas, a $126.279 \mathrm{~m}^{3}$ de água e a uma economia de metade da energia que seria consumida se fosse utilizada apenas a matéria-prima virgem.

As 343 toneladas de vidro recolhido significam a economia de 412.000 toneladas de matérias-primas (areia, barrilha, calcário, feldspato e dolomita). Uma tonelada de vidro velho gera uma tonelada de vidro novo, sem a necessidade de acrescentar nenhuma matériaprima virgem.

As 196 toneladas de plástico recolhido representam uma economia de 250 toneladas de matérias-primas virgens e uma economia de $90 \%$ de energia. Pode-se fazer plástico novo usando $80 \%$ de plástico velho!

As 7,5 toneladas de alumínio recolhido representam uma economia de 37,5 toneladas de bauxita e uma economia de $90 \%$ de energia.

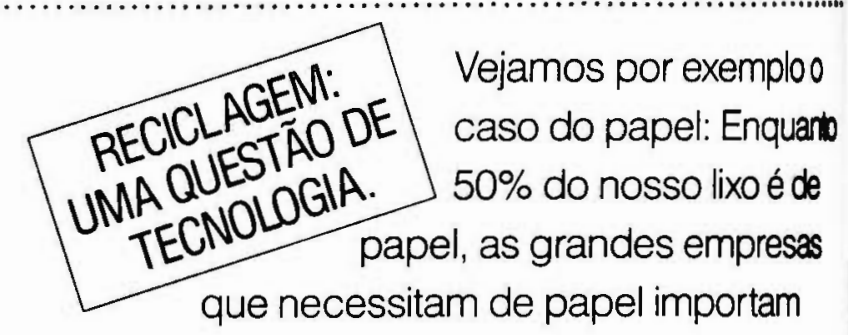

aparas do exterior! Mas o valor do lixo de papel e papelão já é conhecido há muito pelos carrinheiros e catadores de papel, que sobrevivem do comércio desta sucata. $A$ reciclagem do papel exige apenas metade da energia necessária à fabricação de papel novo. Uma tonelada de papel novo exige o uso de 100.000 litros de água; de papel velho, apenas 2000 litros.

\section{Quem cuida da Coleta Seletiva na cidade de} São Paulo é a Divisão

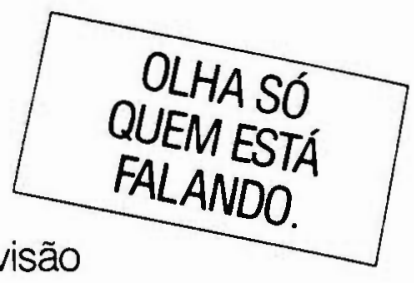
de Coleta Seletiva do Departamento de Limpeza Urbana da Prefeitura de São Paulo.

Você pode telefonar para se informar meihor sobre o programa, fazer perguntas e reclamações. Temos também um Departamento de Educação e Divulgação, que desenvolve um trabalho de esclarecimento sobre o assunto junto às escolas e à população em geral. Fale com a gente!

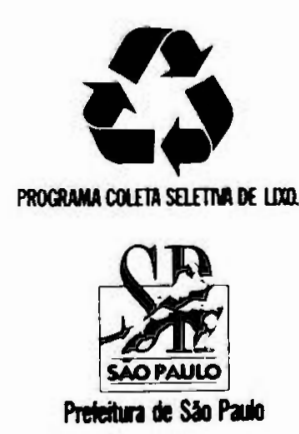

SECRETARIA DE SERVICOOS E OBRAS DEPARTAMENTODE LIMPEZA URBANA - LIMPURB Rua Azurita, 100 - Canindé - CEP 03034 Tel.: 228-4111 - Ramais: 133 e 149. 


\begin{tabular}{|c|c|}
\hline $\begin{array}{c}\text { Centro Educacional e Esportivo do Butantá } \\
\text { Rua Dr. Ernane da Gama Corréa, } 367 \\
\text { BUTANTÁ (AR-BT) }\end{array}$ & $\begin{array}{l}\text { Autódromo de interlagos } \\
\text { Av. Interlagos. } 261 \\
\text { INTERLAGOS (AR-CS) }\end{array}$ \\
\hline \multirow{2}{*}{$\begin{array}{c}\text { Metró Tradentes } \\
\text { Praça Coronel Fernando Prestes, } \\
\text { esquina com Av. Tiradentes } \\
\text { LUZ (AR-SÉ) }\end{array}$} & $\begin{array}{c}\text { Parque ton Carmo } \\
\text { Av. Atonso de Sampaio e Souza. } 951 \\
\text { ITAQUERA (AR-IO) }\end{array}$ \\
\hline & Parque Continental \\
\hline \multirow{2}{*}{$\begin{array}{c}\text { Praca Rotary } \\
\text { Entre Rua Major Sertório e } \\
\text { Rua General Jardim } \\
\text { VILA BUARQUE (AR-SE) }\end{array}$} & $\begin{array}{l}\text { Praça Giovani Montagna, s/n! } \\
\text { PARQUE CONTINEN TAL (AR-LA) }\end{array}$ \\
\hline & $\begin{array}{l}\text { EMPG Prof. Alipio Corréa Neto } \\
\text { Av. João Caiafa, } 140\end{array}$ \\
\hline \multirow{2}{*}{$\begin{array}{l}\text { PUC - Pontificia Universidede Católica } \\
\text { RuA Marqués de Paranaguá, } 111 \\
\text { ONSOLACÁO (AR-SÉ) }\end{array}$} & JARDIM TABOÄO (AR-BT) \\
\hline & $\begin{array}{l}\text { EMPG Poulo Setuibal } \\
\text { Rua Francisco Caldas, } 50\end{array}$ \\
\hline \multirow{2}{*}{$\begin{array}{l}\text { a a Economica Fedoral } \\
\text { Av. Pautlista. 1842 } \\
\text { QQUEIRA CESAR (AR-SE) }\end{array}$} & CAPELLA DO SOCORRO (AR-CS) \\
\hline & $\begin{array}{l}\text { EMPG Prot. Antonio Sampaio Dória } \\
\text { Praça Tito Pacheco. } 7\end{array}$ \\
\hline $\begin{array}{l}\text { coniunto Habitacional do IAPI } \\
\text { Praça Donatello, s/n:. } \\
\text { GLICÉRIO (AR-SE) }\end{array}$ & JARDIM MIRIAM (AR-SA) \\
\hline
\end{tabular}

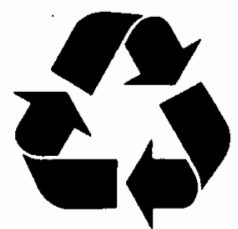

PROGRAMA COLETA SELETIVA DE UXO.

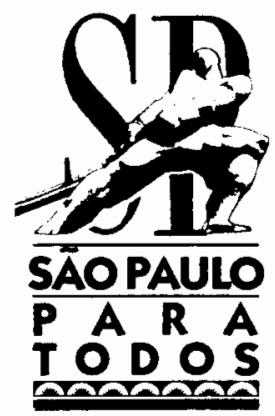

Prefeitura de Săo Paulo

Secretaria de Serviços a Obras

Departamento de Limpeza Urbana - Limpurb

Rua Azurita, 100 - Canindé - CEP 03034

Tel.: 228-4111 - Ramais: 133/149

ste folheto foi produzido em papel reciclado.
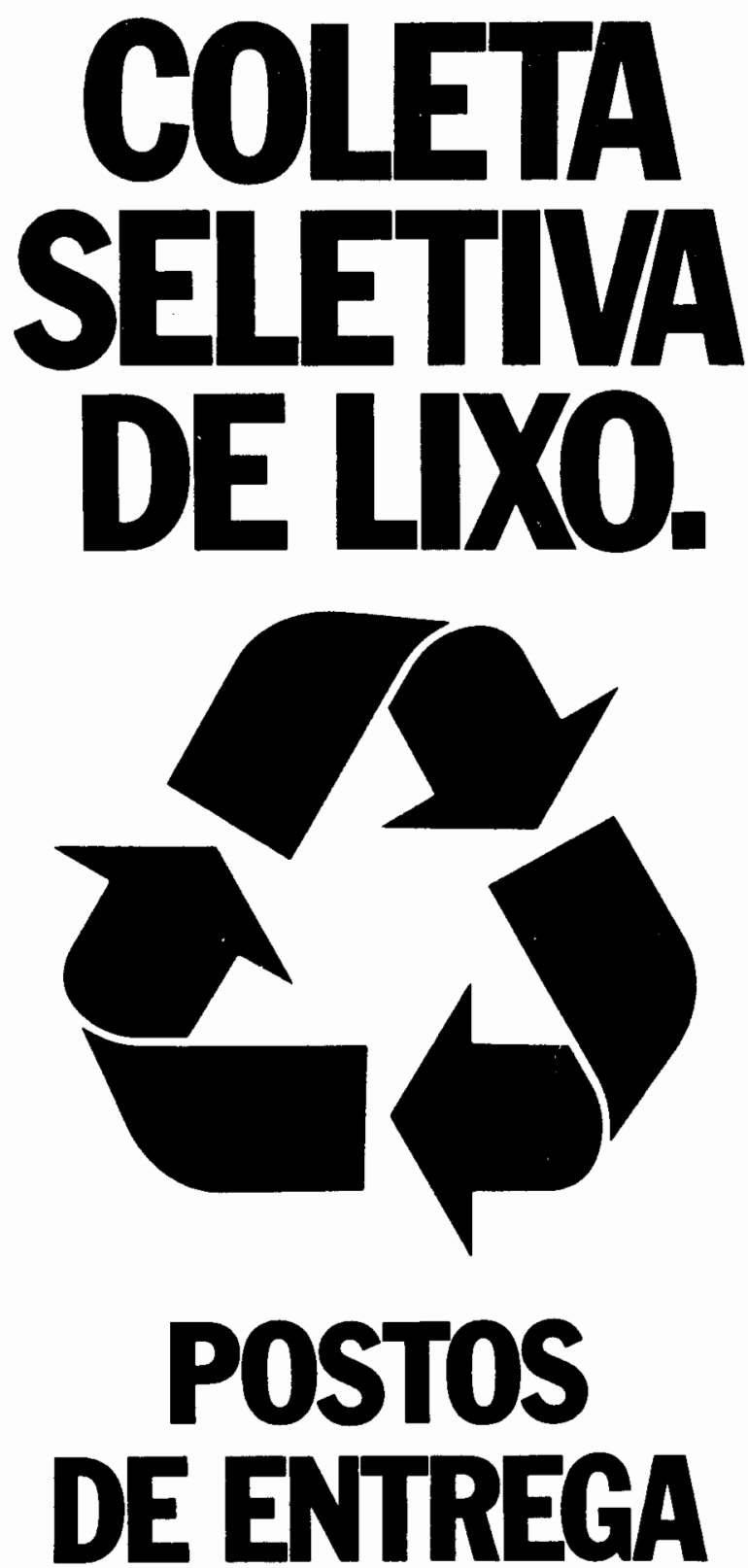

VOLUNTARIA.

$\mathbf{p}$

\begin{abstract}
E
\end{abstract}
V

$\mathbf{s}$ 


\section{0 que é a coleta seletiva de lixo.}

A Coleta Seletiva de Lixo é um programa que visa ensinar a população a se preocupar com o lixo que produz. Ela está sendo introduzida na cidade de forma gradual desde 1989. Consiste na remoção de materiais recicláveis, como: papéis, vidros, plásticos e metais, que foram previamente separados do restante do lixo pela população nas residências, escritórios, etc.

A Coleta Seletiva já é uma realidade em alguns circuitos de ruas na cidade.

Mas mesmo que ela ainda não tenha chegado à sua casa ou escritório, você pode mostrar que entendeu a importância de participar: basta levar o seu lixo até os Postos de Entrega Voluntária, os PEVs.

\section{O que são os postos de entrega voluntária.}

Os PEVs são conjuntos de quatro containers coloridos instalados em locais públicos de fácil acesso. O morador separa o lixo reciclável em casa, no escritório, etc. e leva-o até os PEVs, depositando papéis no container azul, vidros no verde, plásticos no vermelho e metais no amarelo.

Todo o lixo reciclável recolhido pela Prefeitura nos circuitos e nos PEVs é levado ao Centro de Triagem e Reciclagem de Pinheiros, onde é separado e vendido para as indústrias recicladoras. Isto ajuda a reduzir a poluição, economizar energia e matérias-primas e a preservar o meio ambiente.

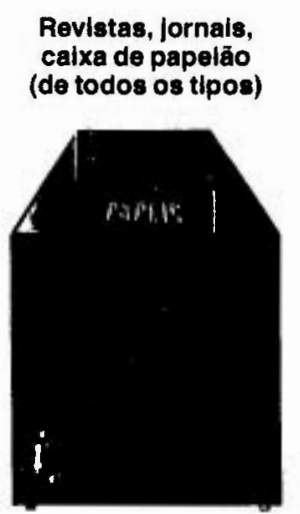

Vidros, garrafas, copos, frascos de remédlos, cacos, etc.
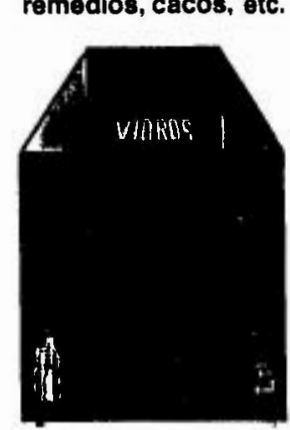

Potes (de todos os tipos), embalagens (de detergente, shampoo água sanitária, etc.), tampas (de todos os tipos), sacos (de leite. arroz, etc.) e outros.
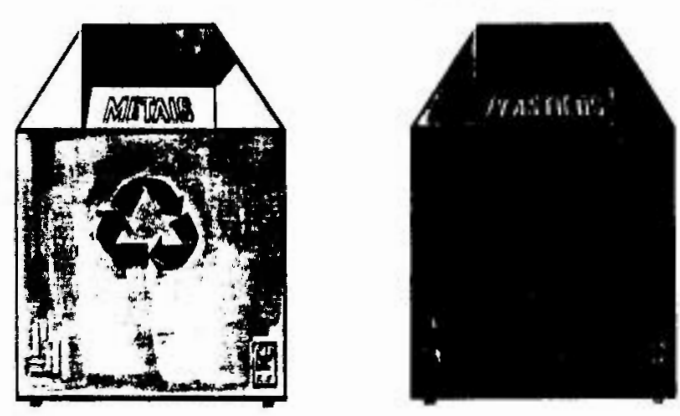

$$
\text { TESC: }
$$

Os seguintes materiais não săo reciclaveis e portanto não devem ser encaminhados a Coleta Seletiva: louças, porcelana, celofane, retaihos de tecidoe carpete, espuma. estopa. pneus, embalagens longa vida, madeira. papel higiênico, guardanapos de papel, filtros de ar de veiculos, papel carbono lâmpadas, cristais, embalagens a vácuo, pilhas e fraldas descartáveis.

\section{- ONDE ENCONTRAR UM PEV.}

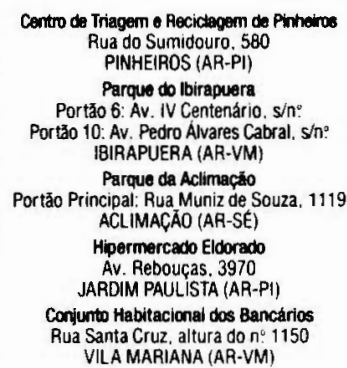

Cidase Universitarí - USP Em frente a0 CRUSP: Av. da Universidade Próximo ao Posts de informaçðes: Av. Ca Universidade
BUTANTÄ (AR-BT) EMPG EMPG AYeres Tradentes Rua Salvador Rodrigues Negrảo, 602 VILA JOANIZA (AR-SA) Parque Sảo Domingos Rua Pedro Senagiotto. 125 Para (AR-PJ) Parque Piqueri Rua Tuiuti, 515 TATUAPE (AR-MO) Parquo Providencia Rua Pedro Piccinini,
BU TANTÁ (AR-BT) 
rUK GUE NAU JUGAK

\section{ESTE FOLHETO HO LIXO?}

Este folheto foi feito com papel que poderá ser novamente utilizado,' se for separado dó seu lixo doméstico. $E$ isso que nós estamos pedindo na Cóleta Seletiva de Lixo: vócê vai participar simplesmente separando do seu fixo o papeláo, papel (éxcetò o higiênico e guardanapos), embalagens plásticas (rigidas e flexiveis), vidros (cacos, garrafas, potës etc.) e os metais (latas, tampinhas etc.). Seu bairro foi escolhido para essa iniciativa inovadora que comieçou na Vila Madalena com muito sucesso. Parabéns, agora é a sua vez de contribuir com a comunidade onde você vive. Mãos à obra, porque seu bairro merece.

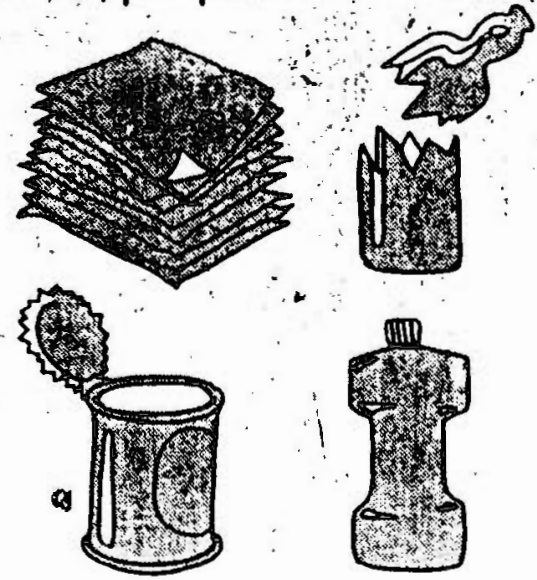

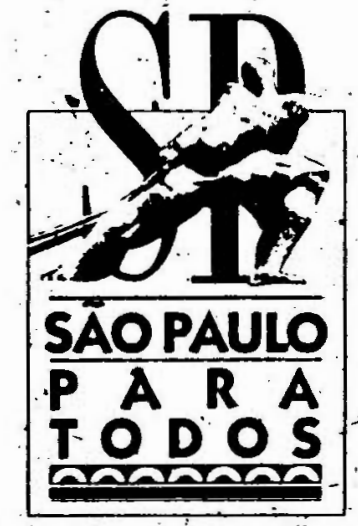

PREFEITURA DO MUNICIPIO DE SÃo PAULO

SECRETARIA DE SERVIÇOS E OBRAS DEPARTAMENTO DE LIMPEZZA URBANA - LIMPURB SECRETARIA DAS ADMINISTRAÇÕES REGIONAIS

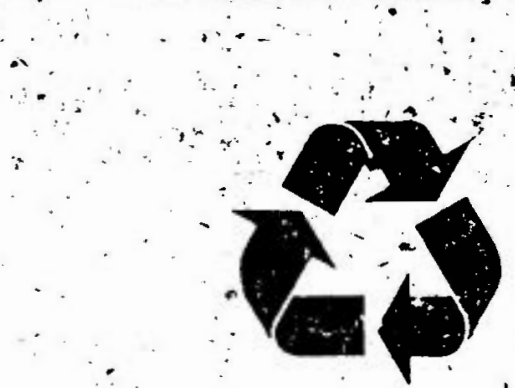

PROJETO COLETA SELETIVA DE LIXO DISQUE COLETA 229-5136 228-4111 R. 149

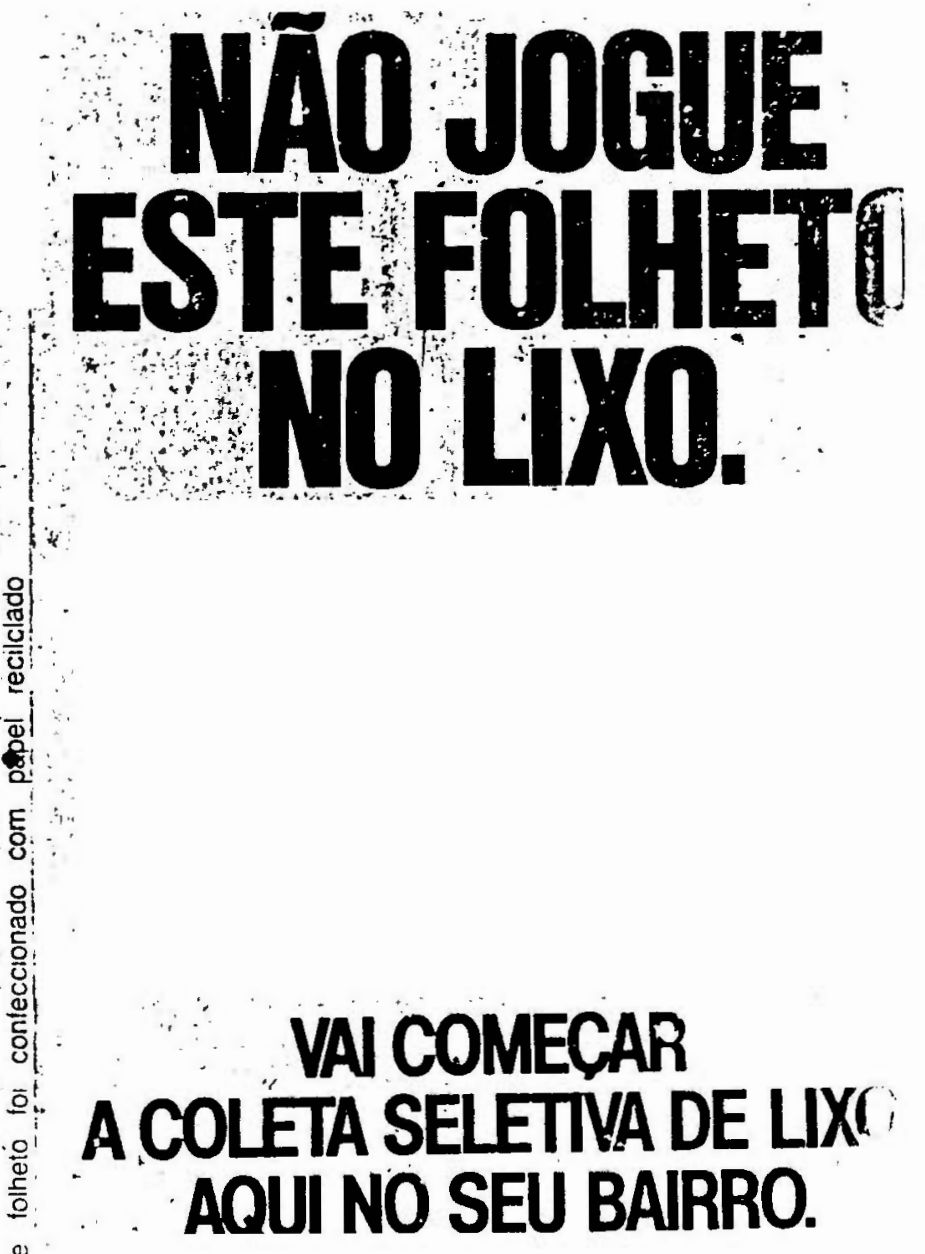
AOUI NO SEU BAIRRO. 


\section{COMO SEPARAR SEU LIXO PARA A COLETA SELETIVA.}

É mais fácil do que você imagina: o lixo. que é lixo (varredura de casa, restbs de comida etc.) vai continuar sendo coletado como sempre. É só você colocá-ló num saco plástico, bem fechado e dejixá-lo em frente à sua casa ou prédio pará quio seja recólhido pelos caminhões nos dias $\theta$ horários habituais. E o lixo separado que é reciclável? Este sim, você vai cólocá-lo no saco da Coleta Seletiva que 'será, semanalmente coletado em seu bairro Os sacos serāo distribuídos pela Prefeltura: tempórariamente, até você adquirir o hábito dá coleta seletiva. A partir de então, vocé podèrá utilizar qualquer tipo de recipiente para acondicionar o material selecionado.

\section{O QUE VOCÊ GANHA COM A}

COLETA SELETIVA DE LIXO.

Para começar, entre as inumeras vantagens dá reciclàgem, está o

Feaproveitamento do lixo e a proteção do

;. meio ambiente com menos poluição do ar a dos rios.

Quandó, por, exempló, o papel é recicládo, as indústrias não precisam derrubar mais

árvores. para fazer um novo papel::

$\because$ Cacos de vidros também são utilizados na fabricação de novas garrafas, com economia de energia, água e. matérias-primas minerais què, na sua

extração, causam grande impacto ambiental. O mesmo acontece com os metais e plásticos: reciclando as sucatas metálicas e o plástico, temos economia de divisas e de petróleo e,

consequentemente, menos ágressẩo ao !meio ambiente:

Entendeu a importância.e utilidadé dessa iniciativa da Prefeitura de São Pauló?

Agora, vamos lá! : :-

Mostre este folheto para seus amigos e vizinhos, promova reuniōes para que todos fiquem cientes desta Campanha, que só vai fazer beri para a saúde da popülação de seu bairro e trazer novos melhoramentos para o bem estar de todos.

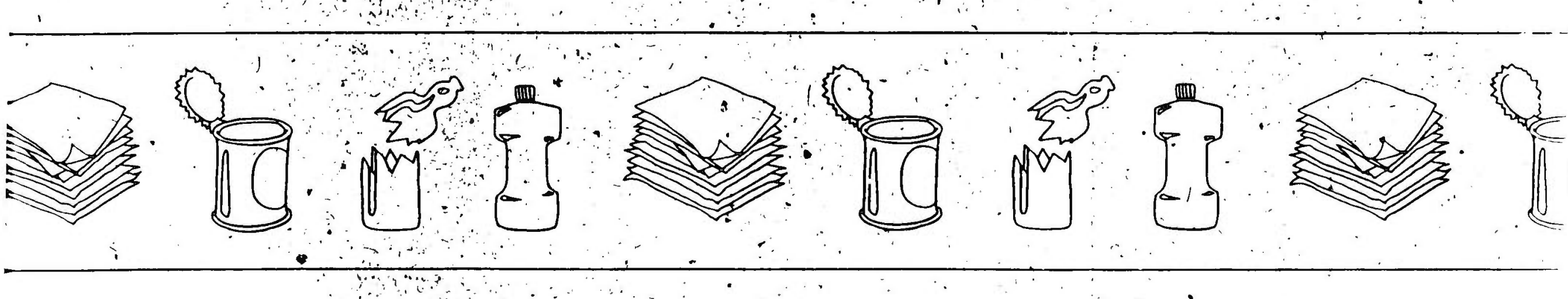

ATENÇĀO: Alguns materiais não são recicláveis e nāo devem ser destinados a coleta seletiva tais como: louças, porcelanas, celofane, retalhos de tecido e carpete, isopor, espuma, estopa, pneus, embalagens Iorna vida, madeira, papel higiênico e guardanapos de papel, filtro de ar de veículos, papel carbono, lampad:": cristais, embalagens a vácuo, pitha e fralda descartável 


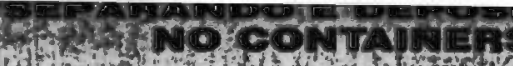

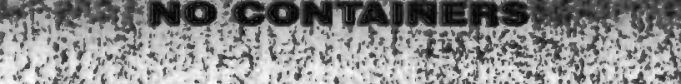

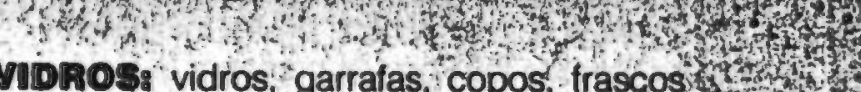
de remedias, copos, trascos

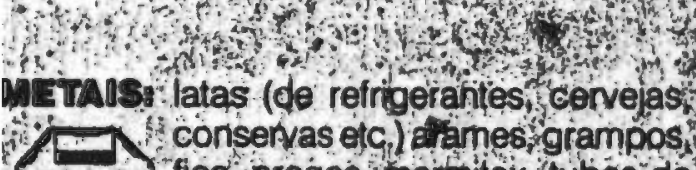

fil fos pregos margitex tubos de

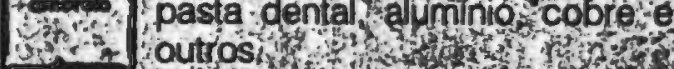

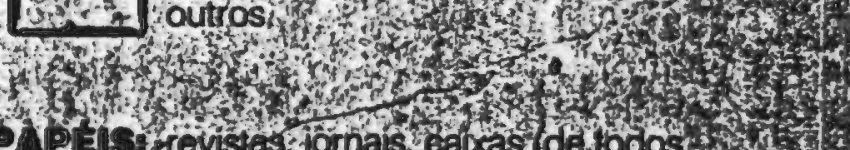
1. 1 os tipos embalagens cadernos

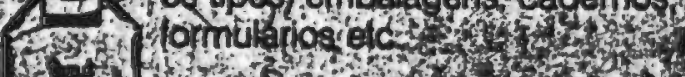
sont

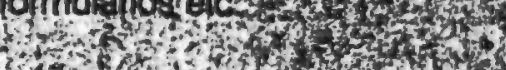

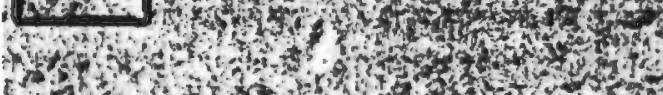

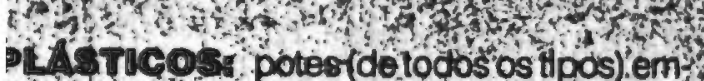
f 7 balagens (dé:'stampoo, de

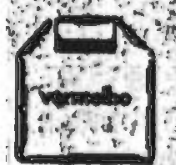
tampas (de todos os tipos)
sacos (de leito, arioz etc.) $4+4$ 100 MENGä
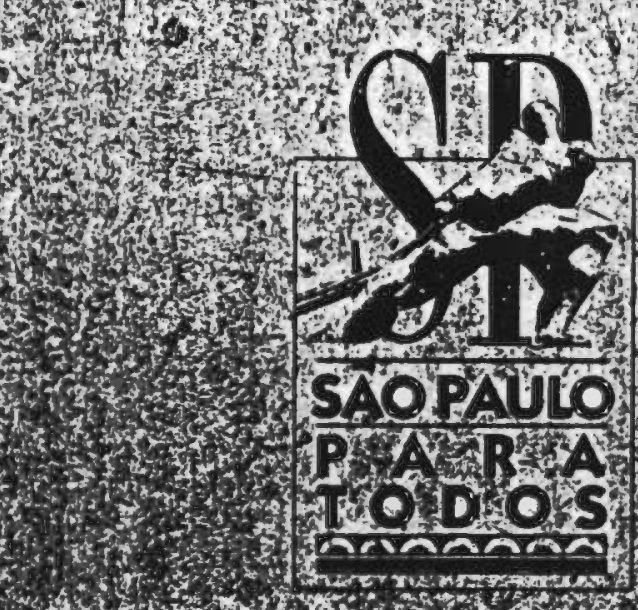

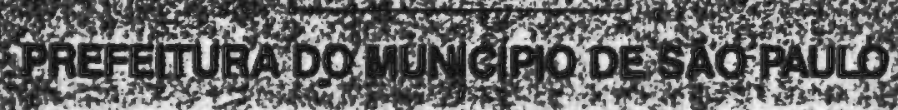

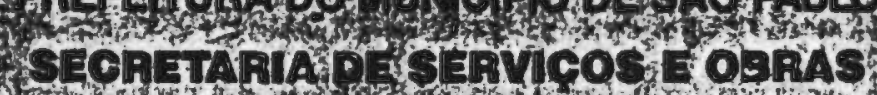
16. SE CRETARIAUUUMTIPÁ DE ELUCACAO

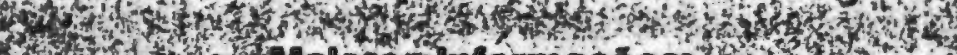

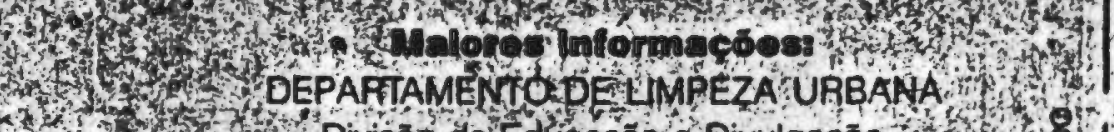

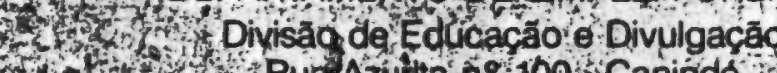

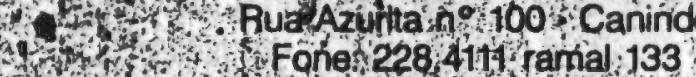

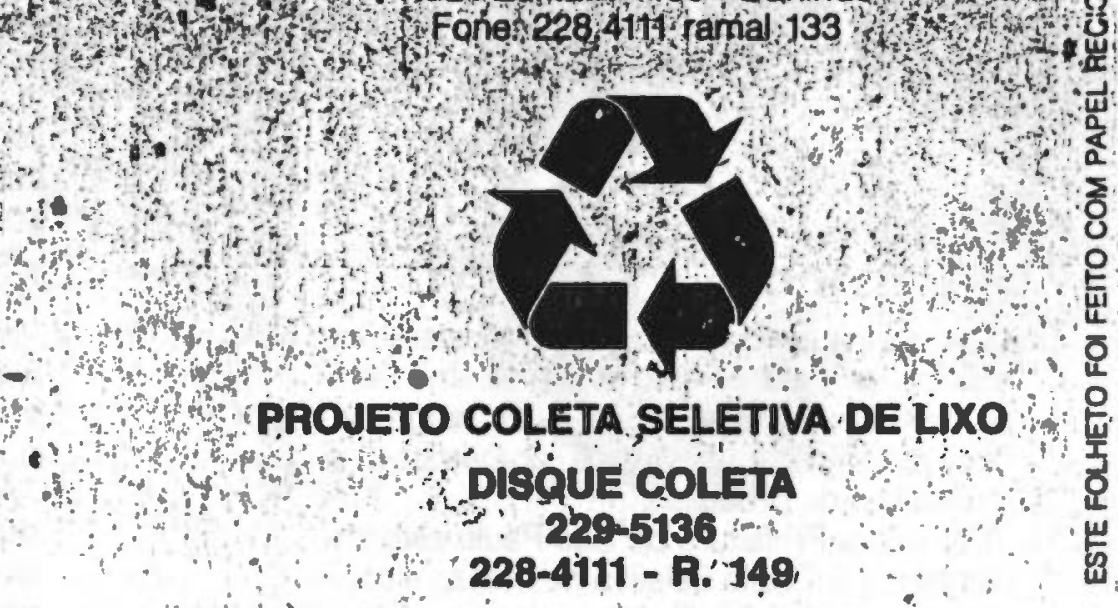
chueis nádos a Coleta Selet lofane, retalhos de fecido carpete, isopor, espuma, esto pa, pneus, cristais, lampadas embalagens longa vida, ma. deira, papel higiênico:e guar danapos de papel, filtro de ar de vuiculos e nuanvil carbono.

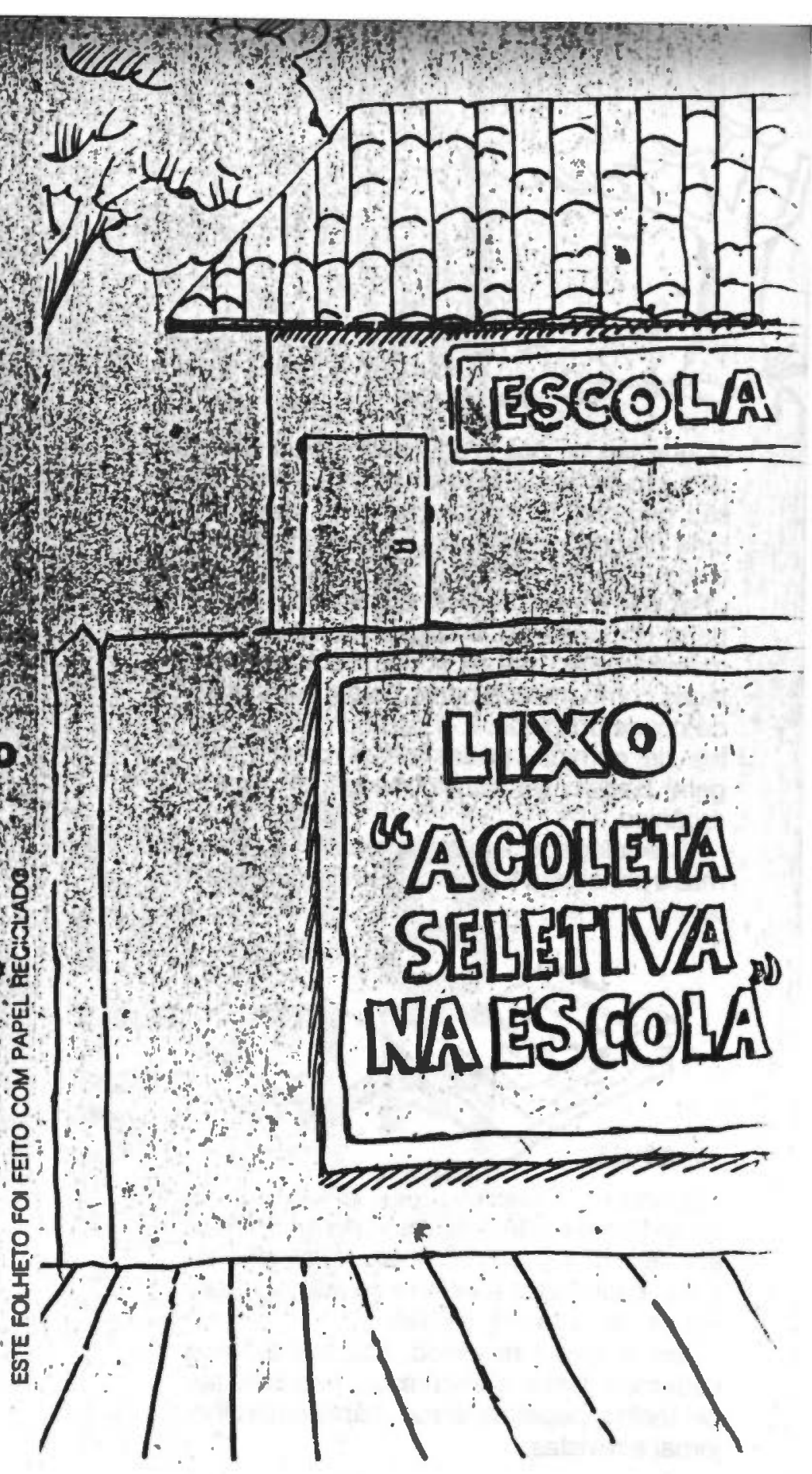




\section{Esclarecimento}

Desde 1989 a Prefeitura de São Paulo vem mplantando a Coleta Seletiva em vários cirmitos de ruas espalhados pela cidade, rewohendo o lixo reciclável uma vez por semana A Coleta Seletiva também recolhe os materiais que a população mais consciente wa aos PEVs-Postos de Entrega Voluntária, hstalados em locais de fácil acesso.

Prefeitura apóia todas as iniciativas esponheas de implantação de Coleta Seletiva omiciliar, e para isso elaborou esta cartilha. las esclarece que nestes casos não se ssponsabiliza pela remoção do material, cando esta tarefa a cargo das próprias omunidades.

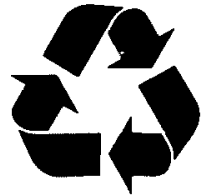

PROCRAMA COLETA SELETTUA DE LIXO.

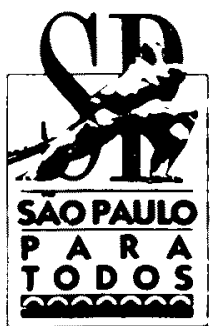

Preteitura de Săo Paulo

Secretaria de Serviçós e Obras lepartamento de Limpeza Urbana - Limpurb

Rua Azurita, 100 - Canindé - CEP 03034

Tel.: 228-4111 - Ramais: 133/149

ste folheto foi produzido em papel reciclado.
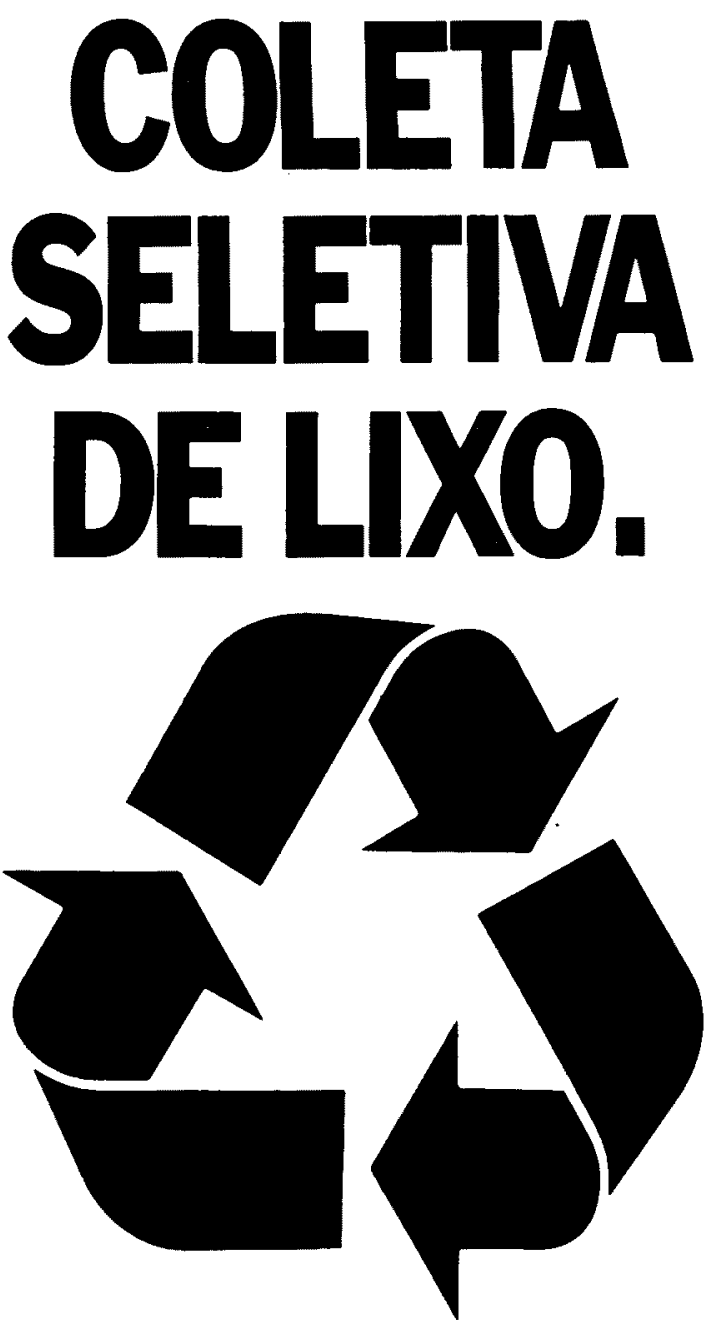

COMO ORGANIZAR A COLETA NO SEU CONDOMINIO. 


\section{0 que é coleta seletiva de lixo.}

Coleta Seletiva de Lixo é um sistema de recolhimento de materiais inorgânicos recicláveis (papéis, metais, plásticos e vidros) previamente separados pelos integrantes de uma dada comunidade. Estes materiais são depois vendidos às indústrias recicladoras ou aos sucateiros.

Uma coleta seletiva pode ser patrocinada pelo poder público ou ser organizada por iniciativa de escritórios, condomínios, etc. Em São Paulo, se a própria comunidade organiza seu sistema de coleta seletiva, ela deve vender o material recolhido ou então levá-lo ao Centro de Triagem da Prefeitura como doação.

\section{Como implantar a coleta seletiva no seu condomínio.}

Antes de implantar a coleta, o condomínio precisa resolver COMO VENDER, COMO ARMAZENARE COMO TRANSPORTAR o seu lixo seletivo.

\section{Como vender o lixo reciclável.}

A venda dos materiais é parte importante. Para contatar os compradores de sucata, procure-os na lista telefônica ou solicite uma lista de sucateiros na Divisão de Educação e Divulgação do Departamento de Limpeza Urbana, Rua Azurita, 100 - Canindé, tel.: 229-4111.

\section{Como transportar o lixo reciclável.}

Muitas vezes os próprios sucateiros retiram o material, mas recolhem apenas grandes quantidades. Quando os sucateiros não fizerem este transporte, recomenda-se a contratação de intermediários.

\section{Como armazenar o lixo reciclável.}

Procure um local abrigado da chuva. duas possibilidades de armazenamento: 1)0 morador utiliza dois sacos de lixo em casa Num ele coloca seu lixo reciclável, seco e limpo do substâncias orgânicas. Noutro ele joga o lixo of gânico: restos de comida, papel higiênico, etc. Alguém deve se encarregar de recolher e arma zenar o lixo reciclável até que seja recolhido. 8 Outra possibilidade, mais adequada, é defin um local onde se possa instalar quatro latöes containers coloridos, um para cada tipo de lixo. vermelho para plásticos, azul para papés, ama relo para os metais e verde para os vidros. Cadk morador deve levar seu lixo seletivo até os latões

\section{Como divulgar a coleta seletiva entre os moradores.}

Só a participação ativa de todos os mora dores garante o sucesso da coleta. Divulgue esclareça o projeto com folhetos e cartazes.

\section{Como manter a coleta seletiva em funcionamento.}

Depois de implantar a Coleta Seletiva, a responsáveis devem:

1. Manter os moradores informados, discutind aperfeiçoamentos e o destino do dinheiro ar recadado. 2. Manter contato permanente con a Divisão da Coleta Seletiva do LIMPURE (tel.:228-4111-R.128), que fornece todo o apoin técnico para o êxito destas iniciativas. 


\section{PRESERVE}

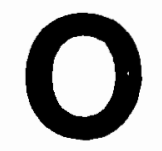

MEIO AMBIENTE !

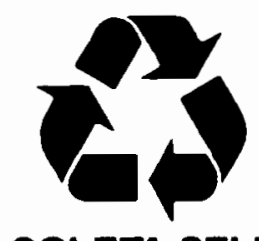

PROJETO COLETA SELETIVA DE LIXO

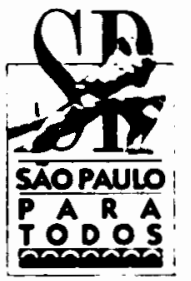

PREFEITURA DO MUNICIPIO DE SÃO PAULO SECRETARIA DE SERVIÇOS E OBRAS DEPARTAMENTO DE LIMPEZA URBANA - LIMPURB

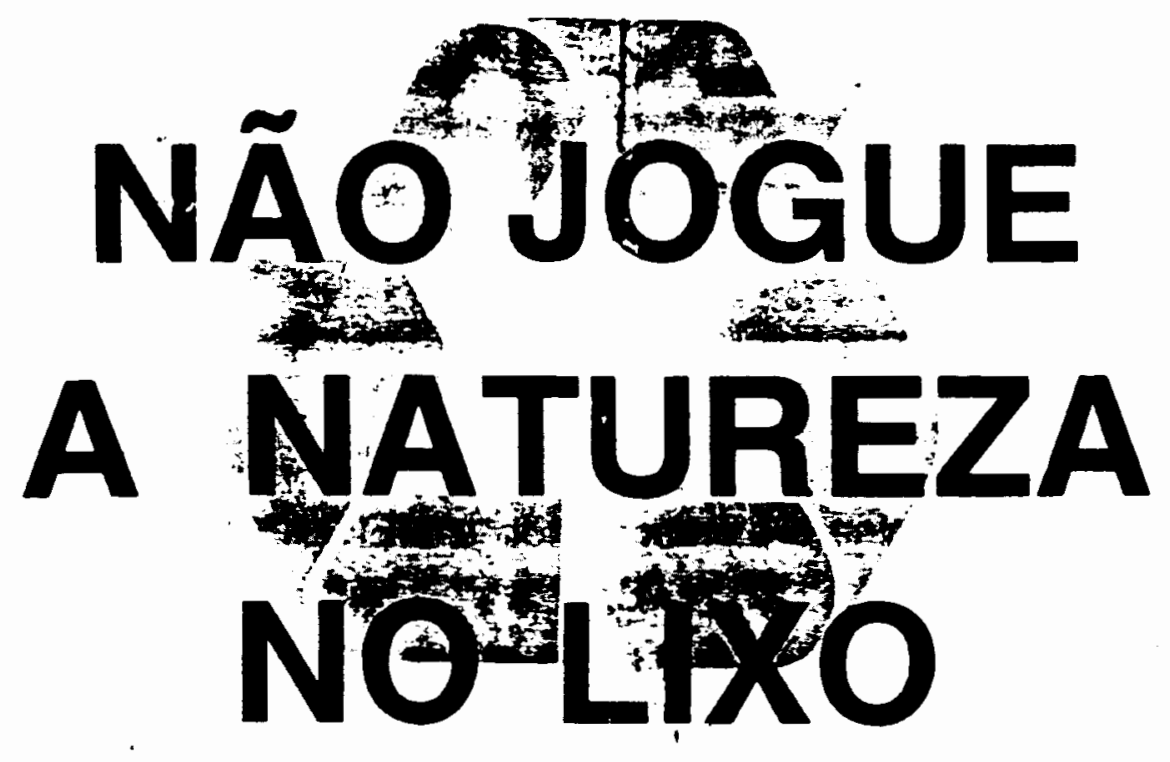




\section{RECICLANDO}

A maior parte das 12.000 toneladas/dia do lixo da cidade é depositada nos ATERROS SANITÁRIOS, poluindo o soloeagredindo o meio ambiente,

Além disso, matérias-primas recicláveis reaproveitáveis - são desperdiçadas e assim, mais árvores e recursos minerais sãoextraídos danatureza.

Foi pensando em tudo isso que a PREFEITURADO MUNICIPIO DE SÃO PAULO implantou o projeto de "COLETASELETIVA"nacidade.

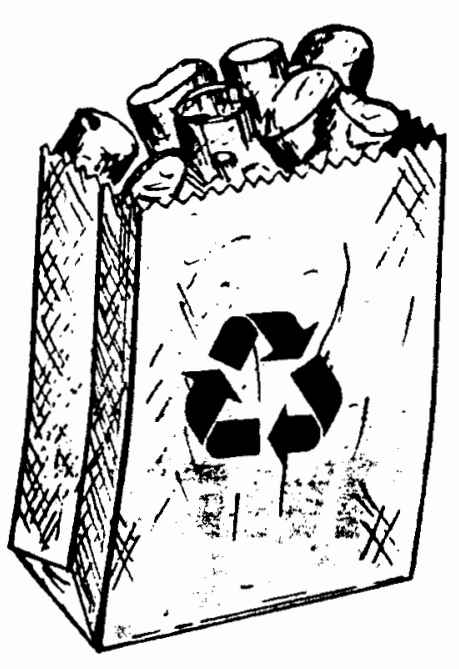

\section{SEPARANDO E DEPOSITANDO NOS CONTAINERS}

Você pode participar separando o lixo em sua residência e depositando corretamentenos CONTAINERS.
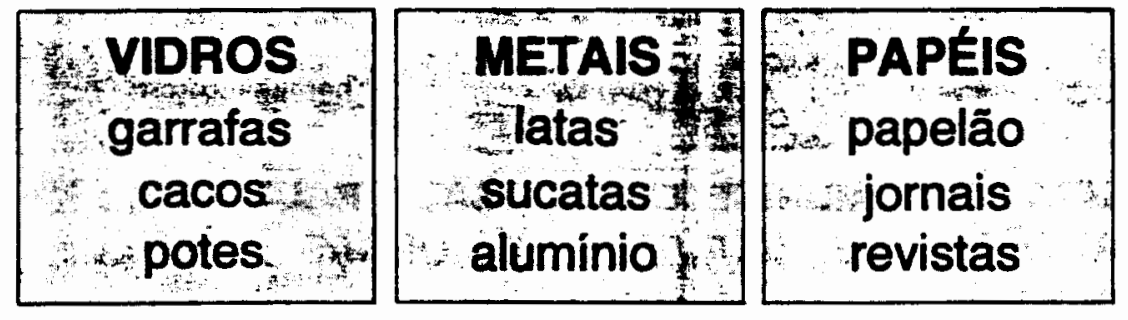

PLASTICOS
embalagens
duras
flexiveis
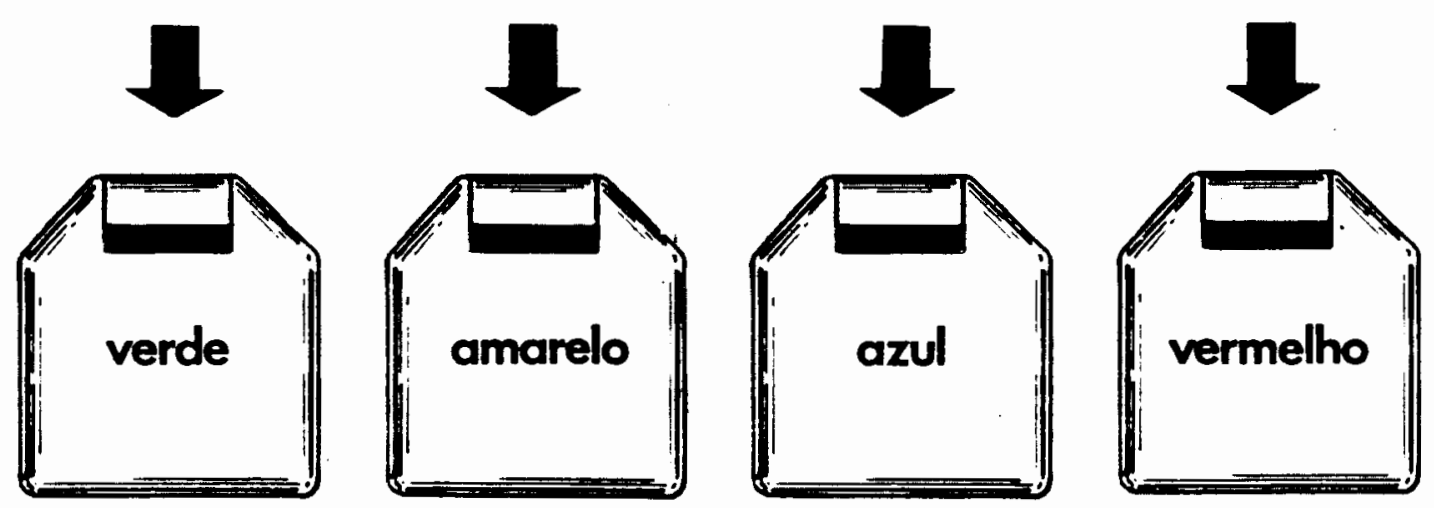

Esses materiais se transformam em matéria-prima para indústrias reduzindỏ a poluição, economizando energia mineral e preservando o MEIO AMBIENTE.

ATENÇÃO:

NĀO DEPOSITE PAPEL HIGIÊNICO, LOUÇAS, PILHAS, ISOPOR, LATAS DE AEROSOL, EMBALAGENS À VÁCUOE TIPO LONGA VIDA - MATERIAIS NÄO RECICLÁVEIS.

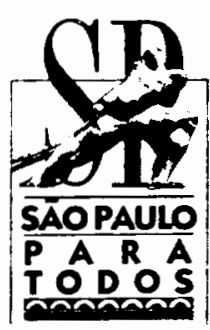




\section{LIMPEZA URBANA}
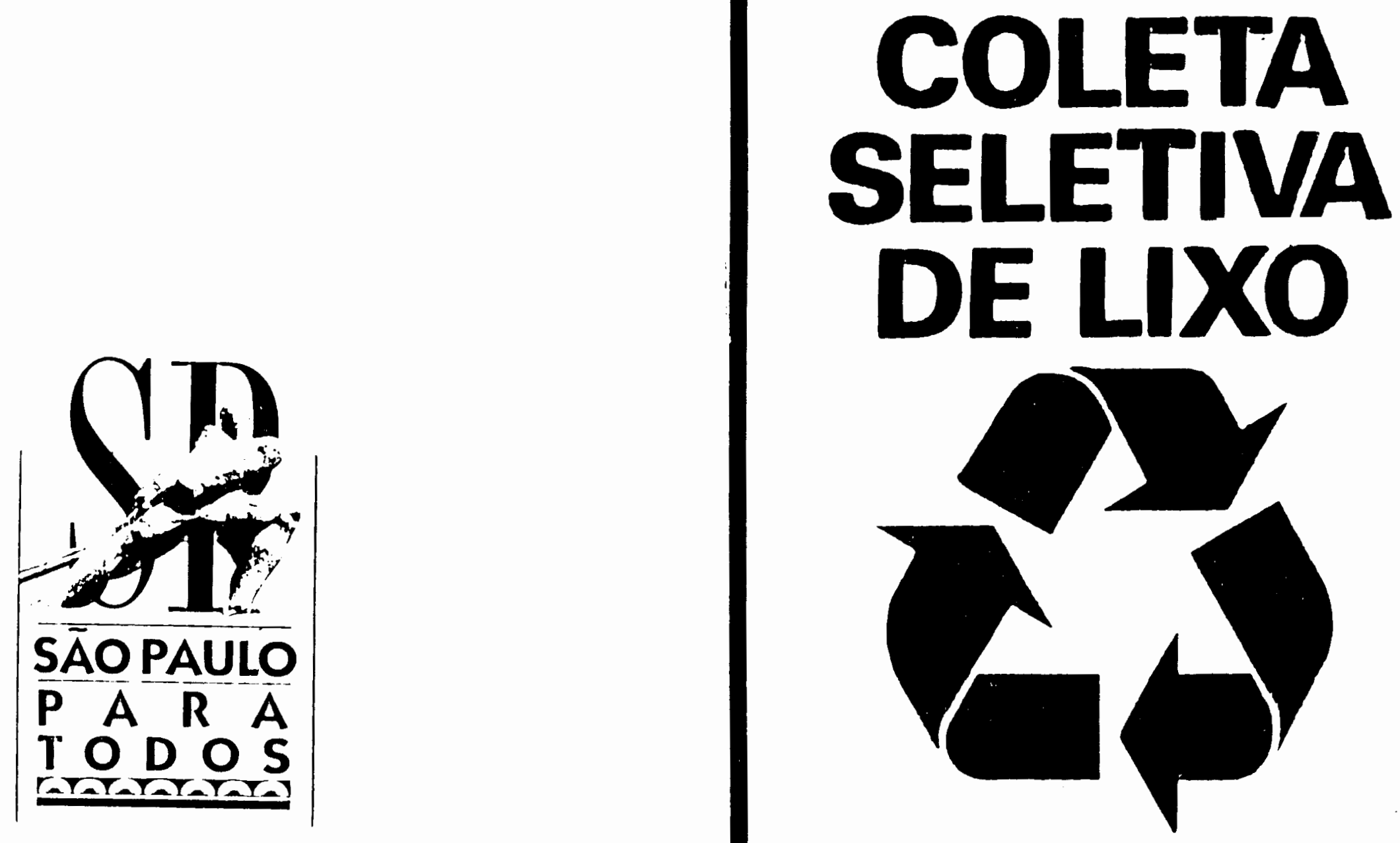

PREFEITURA DO MUNICIPIO DE SÃO PAULO 
Diarramente Sāo Paulo produz $12.0001 /$ dia de lixo, isto representa aproximadamente $1 \mathrm{~kg}$ de residuos por pessoa.

Podemos comparar esta

quantidade com

um esládio de fulebol cheio de lixo,

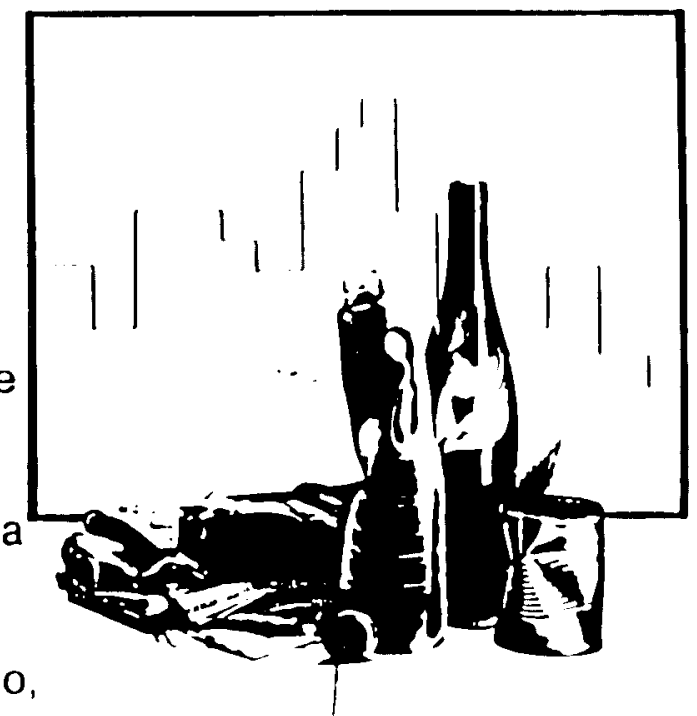

ou quase $2000 \mathrm{~km}$ de sacos (le lixo (20) 1 ) enfileirados, uma distância equivalente: a São Paulo/Salvactor

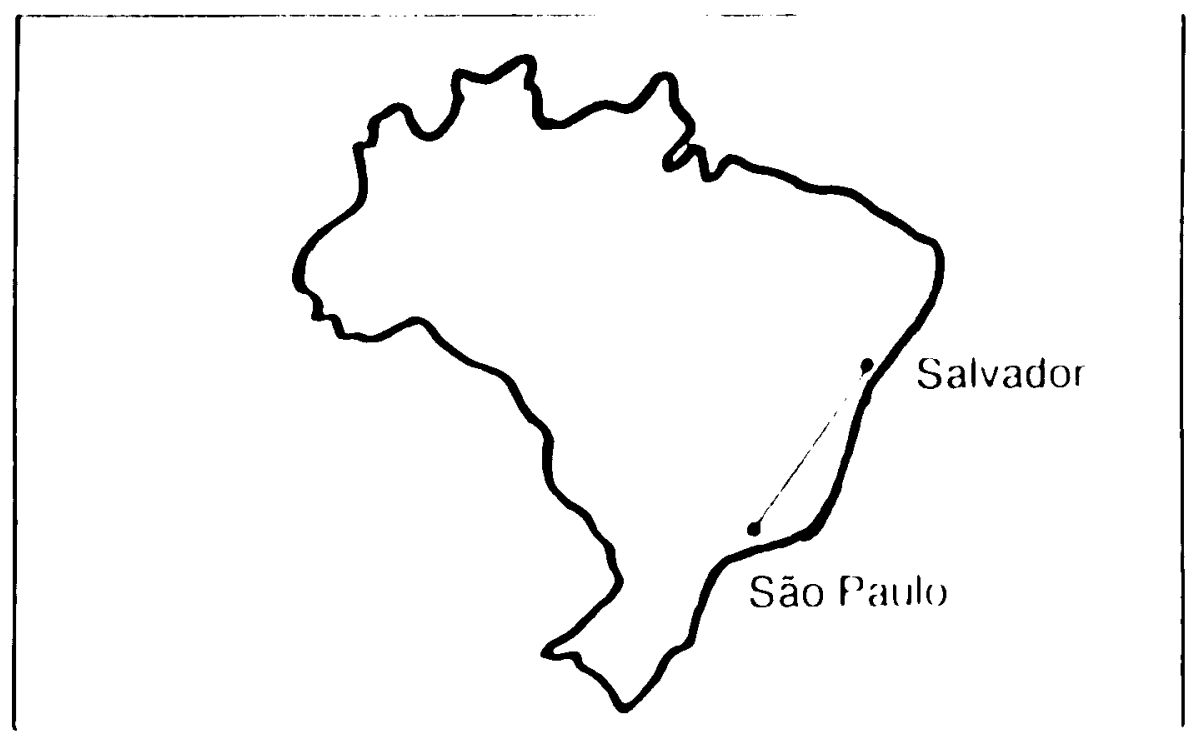


A Prefeitura do Municipio de Sāo Paulo coleta e destina esses residuos de quatro formas, sāo elas:

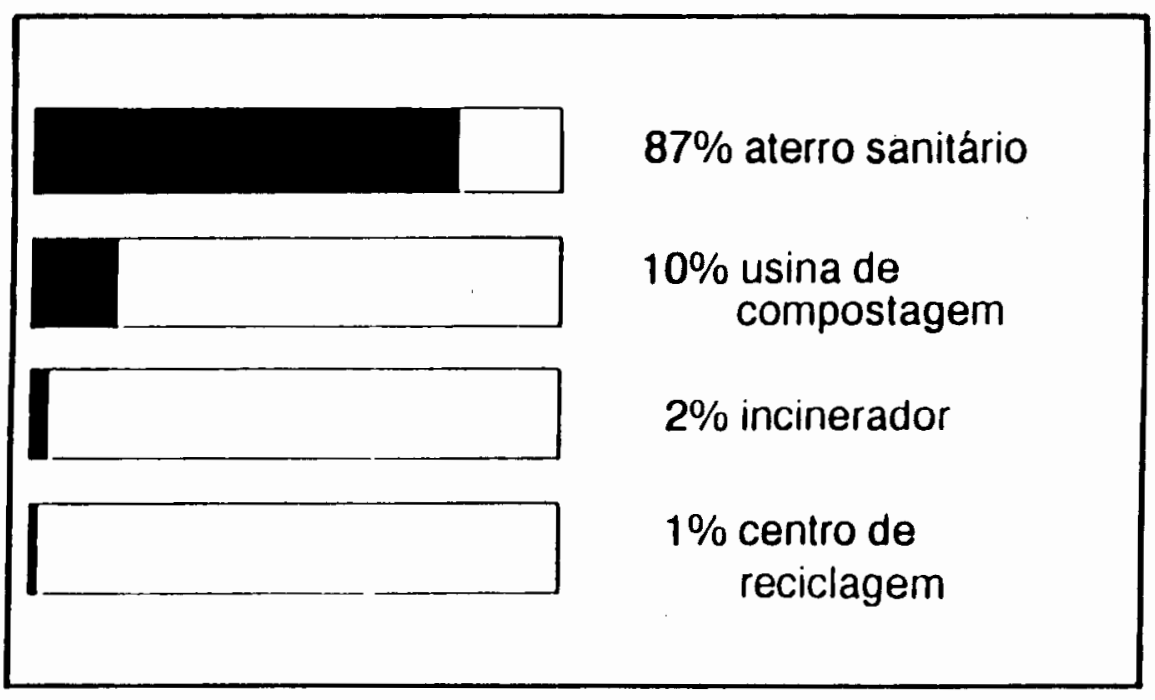

\section{Aterros Sanitários}

Os quatro aterros em atividade recebem a maior parte dos residuos da cidade, onde o lixo é enterrado observando-se alguns cuidados técnicos para não poluir o meio ambiente. No entanto, o desperdicio é muito grande uma vez que materiais que poderiam ser reaproveitados estāo sendo enterrados.

\section{Usinas de Compostagem}

As duas usinas existentes recebem o lixo proveniente das residências devido a grande quantidade de matéria orgânica presente. Este sistema de destinação aproveita a fração orgânica transformando-a em composto (adubo de alto valor agricola).

\section{Incineradores}

Consiste num sistema de destinação que elimina o lixo consideraḍo perigoso ou contaminado, proveniente dos serviços de saúde. A queima, em alta temperatura, destes residuos resulta em cinzas nāo prejudiciais ao contato humano.

\section{Centro de Reciclagem}

Para este local são encaminhados os materiais recolhidos pela "coleta seletiva de lixo"

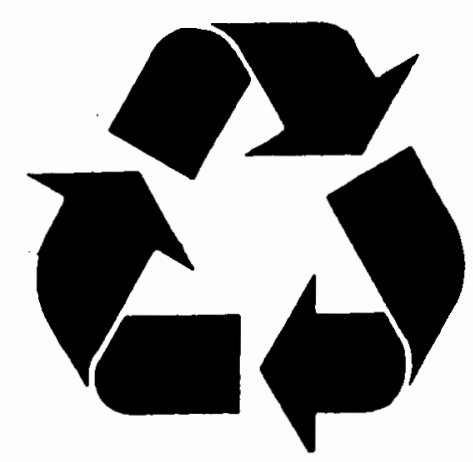




\section{O aproveitamento do "lixo" \\ é uma preocupação} mundial

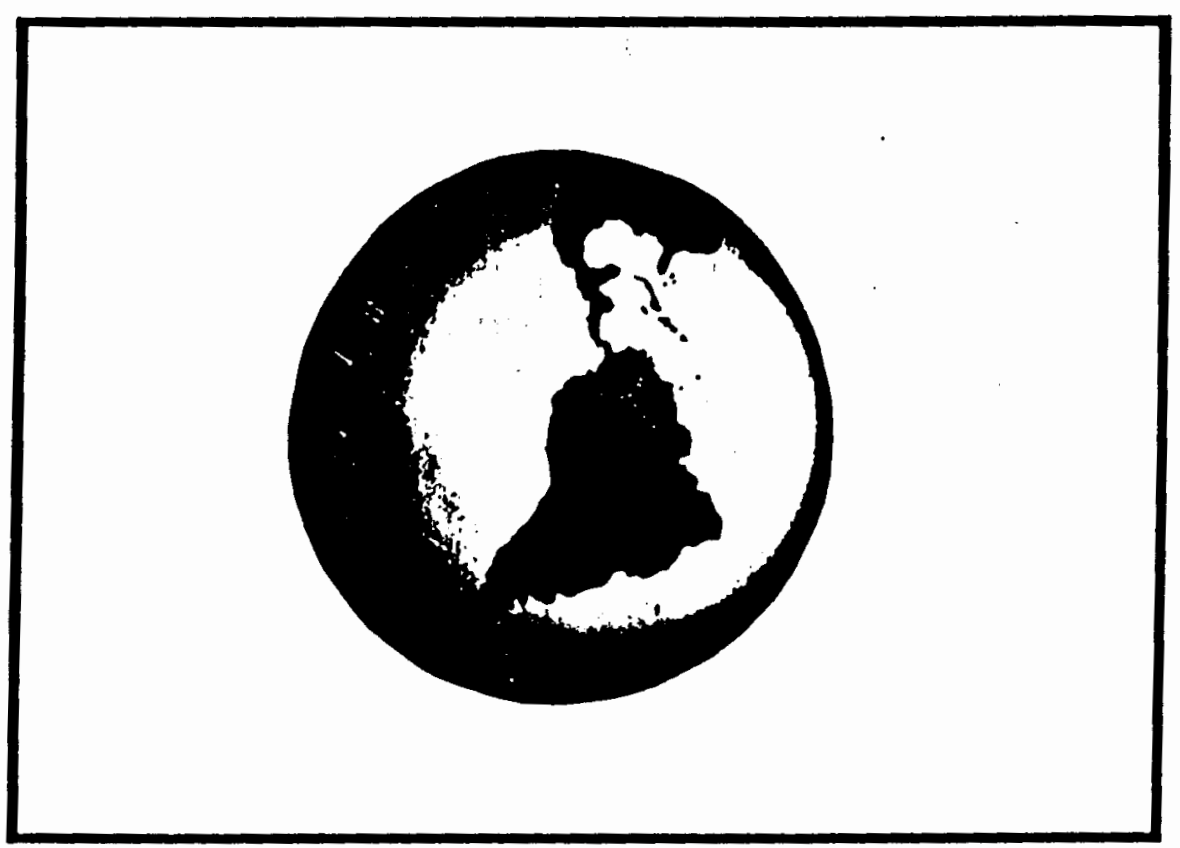

- As fontes de extração de matérias-prima estão se esgotando.

- Existem dificuldades em se encontrar áreas para a disposição dos residuos.

- Alguns sistemas de destinação além de extremamente onerosos, desperdiçam materiais que poderiam ser reciclados.

\section{composição média do lixo paulistano}

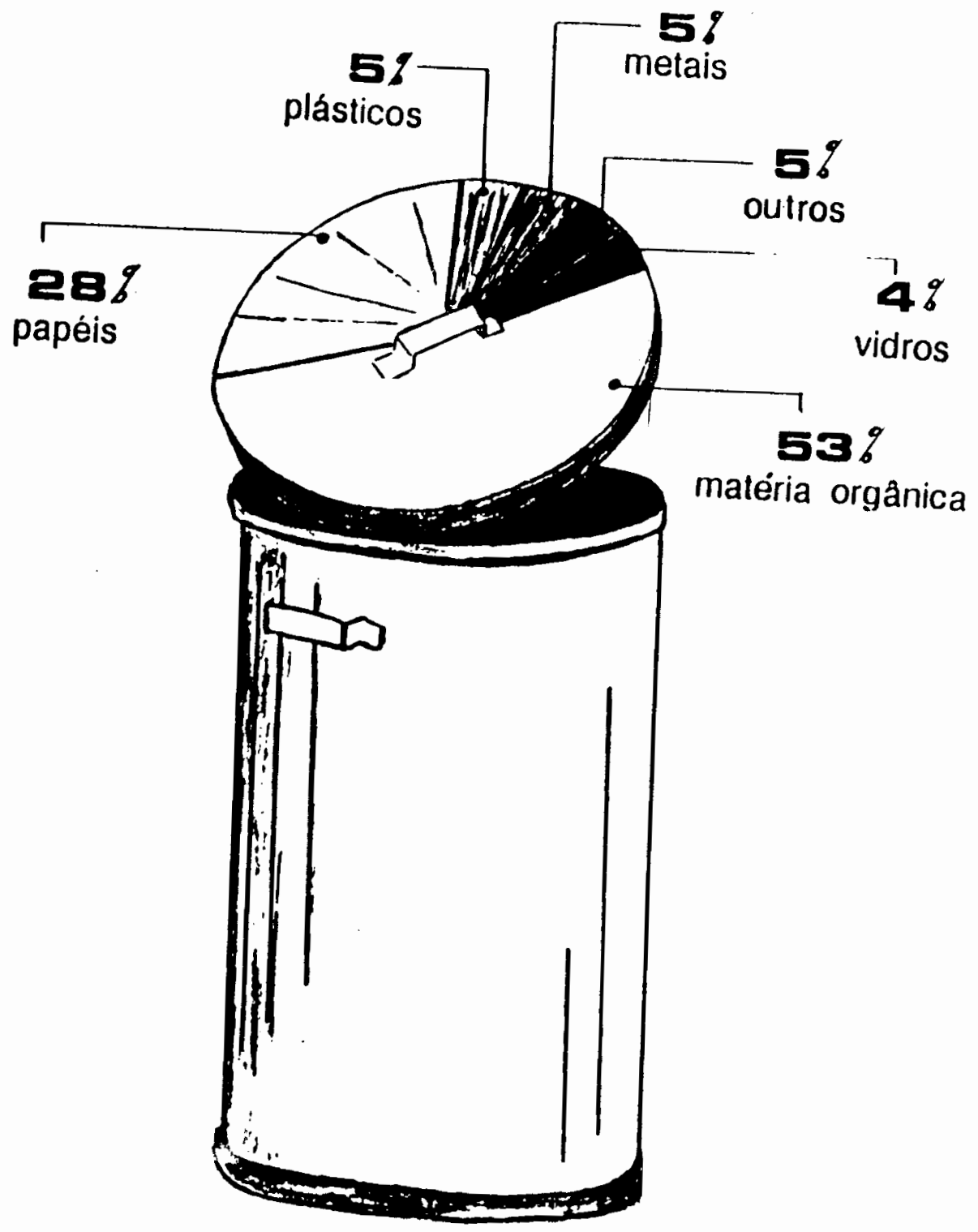




\section{COLETA SELETIYA DOLIXO}

É a separação na fonte geradora dos materiais recicláveis ou reutilizáveis, antes de serem desprezados como lixo.
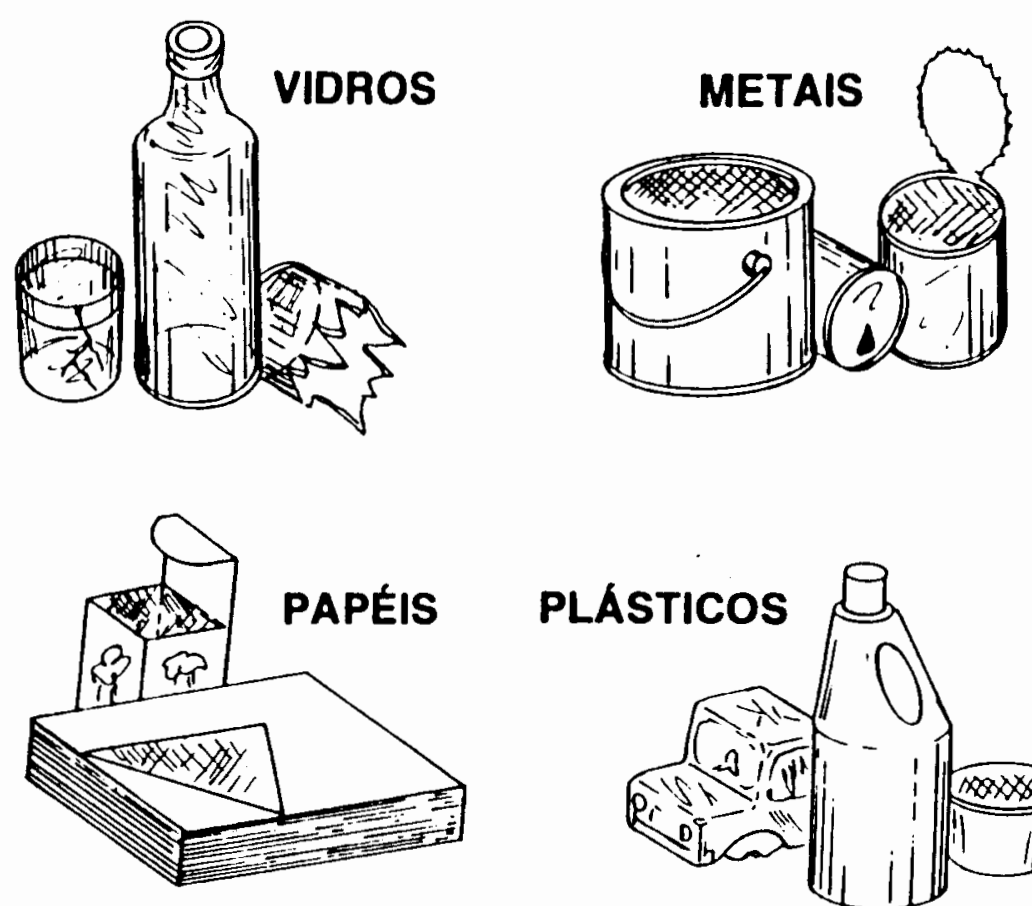

Procedimentos na separação do lixo

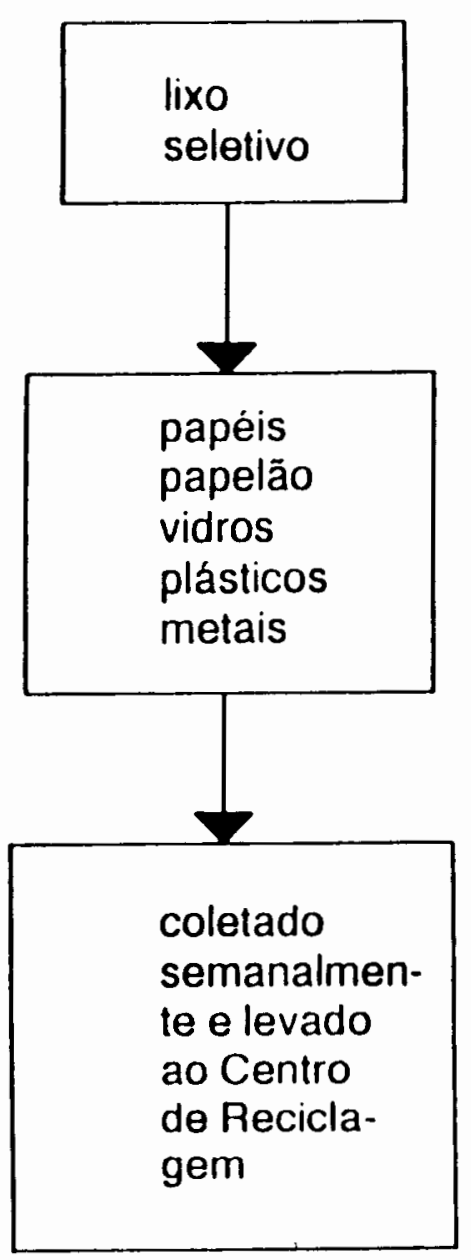


A coleta seletiva de lixo está sendo introduzida na cidade de São Paulo de forma gradual.

São estabelecidos circuitos que aos poucos se ampliam formando "manchas"na cidade.

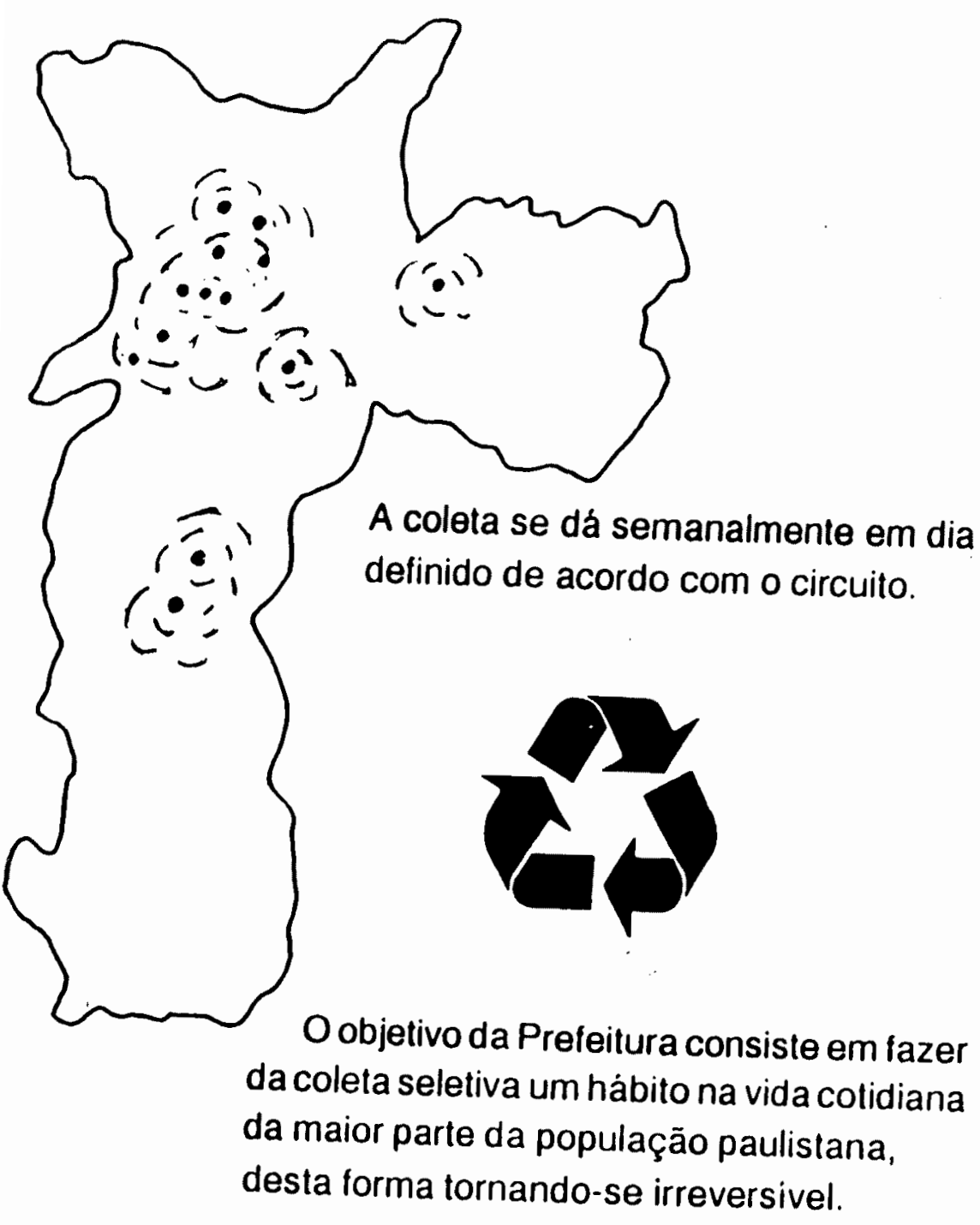

\section{Centro de Reciclagem}

Atualmente o projelo conta com um Centro de Reciclagem, de Pinheiros; $\dot{A}$ medida que o projeto se ampliar novas instalaçōes serão providenciadas. Os diferentes materiais chegam misturados e passam por uma primeira separaçāo:

\begin{tabular}{|l|l|l|l|}
\hline plasticos & latas & papéis & vidros \\
\hline
\end{tabular}

Depois de separados, são classificados e acondicionados de acordo com sua comercialização, para posterior reciclagem nas indústrias.

A coleta seletiva de lixo nos beneficia no seguinte:

1 - Economia de divisas - O Brasil está gastando dólares para comprar materiais recicláveis (aparas de papel, sucata de ferro, residuos industriais...) que aqui têm ido para o lixo.

2 - Economia de energia - Os materiais recicláveis exigem menos energia para serem reprocessados.

3 - Ação ecológica concreta - Menos poluição ambiental na manufatura dos produtos. 

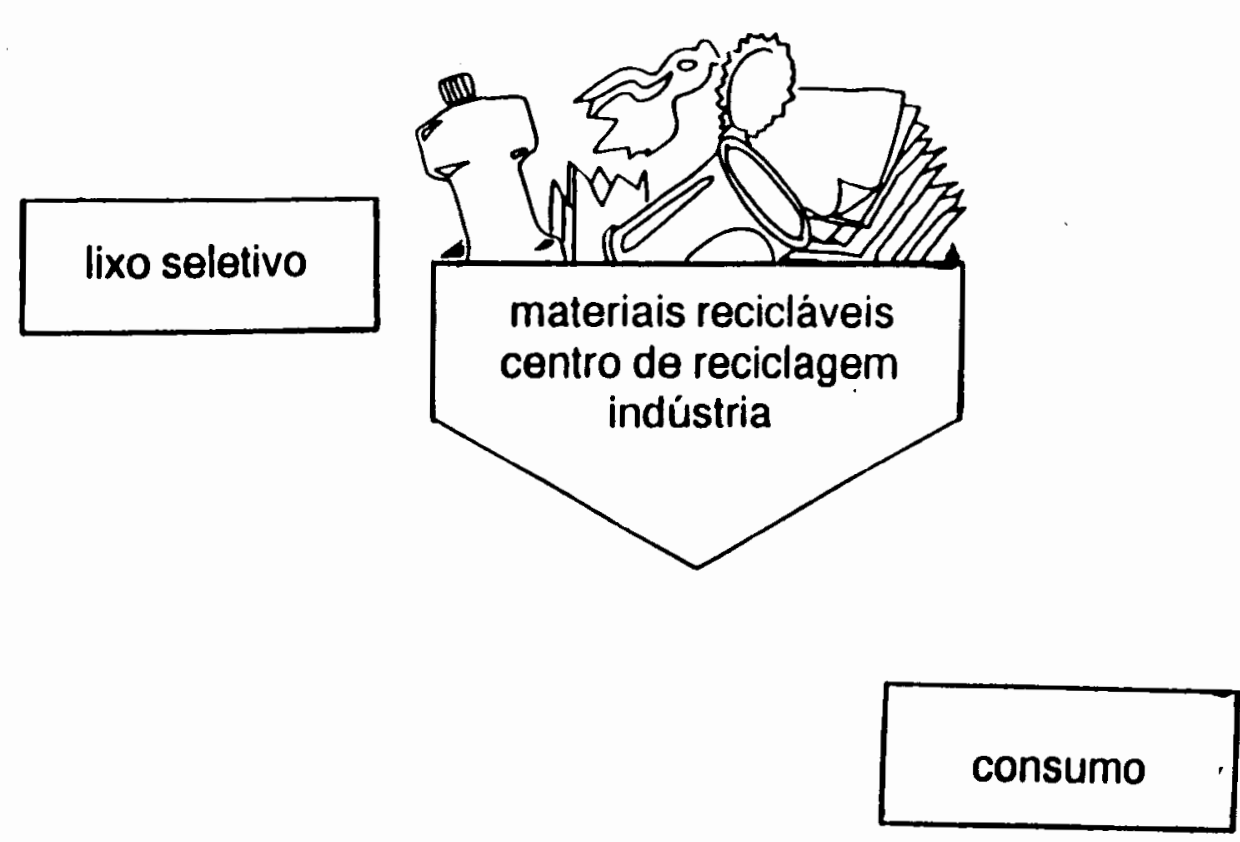

lixo orgânico

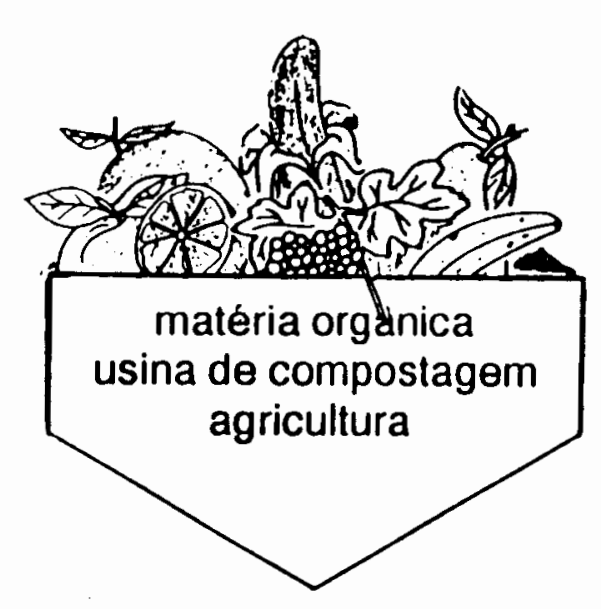

A iniciativa de implantaçāo deste projeto foi de grande importância, pois o lixo recupera o seu valor, aumentamos a vida útil dos aterros sanitários, a natureza é preservada e melhora a qualidade de vida urbana.

\section{Faz parte do projeto a implantação de} Pontos de Entrega Voluntária de materiais.

\section{Os PEVS - consistem um conjunto de} quatro containers de cores diferentes, uma para cada tipo de material, acompanhados de uma placa educativa.

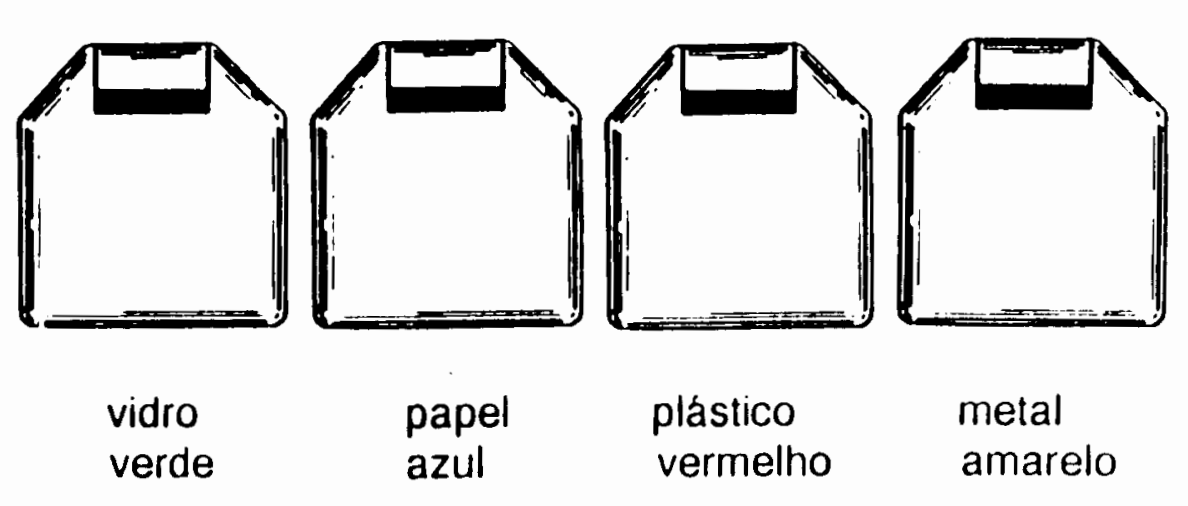

Estes estão sendo implantados em alguns parques da cidade, conjuntos habitacionais 
e em locais de grande concentração populacional e de fácil acesso.

A coleta destes materiais, é feita por caminhōes especiais e os materiais encaminhados ao centro de reciclagem.

A participação popular onde a Coleta Seletiva já foi implantada traz resultados bastante animadores, a adesão é de aproximadamente $70 \%$.

Acreditamos que todo este trabalho acarretará futuras mudanças de comportamento em relaçāo aos desperdicios e produzirá reflexos na área da limpeza urbana.

O trabalho educativo vem sendo feito junto as escolas, associações de bairros e atendimentos a pessoas que procuram orientações sobre o projeto.

\section{Estamos trabalhando $e$ aceitamos a sua colaboração neste projeto que visa a melhoria da qualidade de vida para o conjunto da população.}

\section{Departamento de Limpeza Urbana}

LIMPUAB - Tel.: 228-4111.

Divisão de Educação e Divulgação - ramal - 133
Gráfica

Servicgo funerarlo 
‥5. FAVELA MONTE AZUL

Antes de procedermos à síntese do estudo realizado é conveniente a inclusäo. como experiência pioneira de coleta seletiva da cidade de São Paulo. do projeto desenvolvido desde meados de 1989. na Favela Monte Azul, situada no Jardim Monte Azul, regiāo próxima à Ponte João Dias da Marginal pinheiros. A coleta seletiva foi implantado por iniciativa do Programa de Saúde Pública do Ambulatório da Associação Comunitária Monte Azul.

\begin{abstract}
A Favela Monte Azul é um caso a parte dentro do universo dos aglomerados urbanos, cada vez mais munielosos. mpulosos e desassistidos. Em ianeiro de 1979 a perdagosid lite craemer tundou a Associacáo Comunitária Monte Azul (ACA A $)$ que conta atualmente com 60 colaboradores da própria lavela. e 20 voluntarios do Brasil e do exterior(35).
\end{abstract}

Em 1989. sob a assessoria do Professor Emilio Eigenheer construiu-se um galpão para armazenamento dos materiais recolhidos. e implantou-se a coleta seletiva. inicialmente para cinquenta casas da favela e cinquenta dos arredores. 
Estas fanilias recebiam um vasilhame de plastico cada e. a partir de folhetos explicativos e esclarecimentos verbais. eram orientadas quanto à separação de papeis. metais. plásticos e vidros.

Os resíduos restantes, deveriam ser depositados em cacambas colocadas ao redor da favela. Este projeto visava incentivar os moradores a cuidar da limpeza da lavela.e a manter limpo o córrego que a atravessa, ao mesmo tempo que possibilitava um destino adequado, tanto para os materiais recicláveis. quanto para os resíduos restantes.

Esse proieto envolvendo coleta seletiva e destinacão adequada dos resíduos produzidos na comunidade. foi incorporado às outras atividades desenvolvidas pela ACOMA lbercários. creches. jardins de infância, pré-escolas, complenentacáo e reforço escolar. ambulatório médico e dentário, grèmio recreativo. centro cultural, grupo de mulheres. entre ontrasl. sendo a questajo trabalhada no cotidiano de cada atividade.

O Grupo de Mulheres montou uma of icina We papel artesanal. risando desenvolver reciclagem artística sob enconienda. e onde as crianças e os colaboradores pudessem aprender reciclar papel artesanalmente. 
Desde 1990 a média mensal de material

conercializado é de 1.5 tonelada. que é entregue pelos moratores no centro de triagem da favela. De acordo com o Sr. Antonio. responsàvel pela separacảo e venda do material arrecadado, este era composto por $40.9 \%$ de papel, $12.4 \%$ de plástico. $23.9 \%$ de vidro e $22.8 \%$ de latas e outros metais, sendo que o rejeito (material entregue pela população. não passível de comercializaçāo) não foi avaliado. A composição do material coletado encontra-se na figura 10. As próprias oficinas da favela reciclavam ou reutilizavam mensalmente. em média, 70 quilos de papel e parte dn vidro. 
FIGURA 10 - FAVELA MONTE AZUL

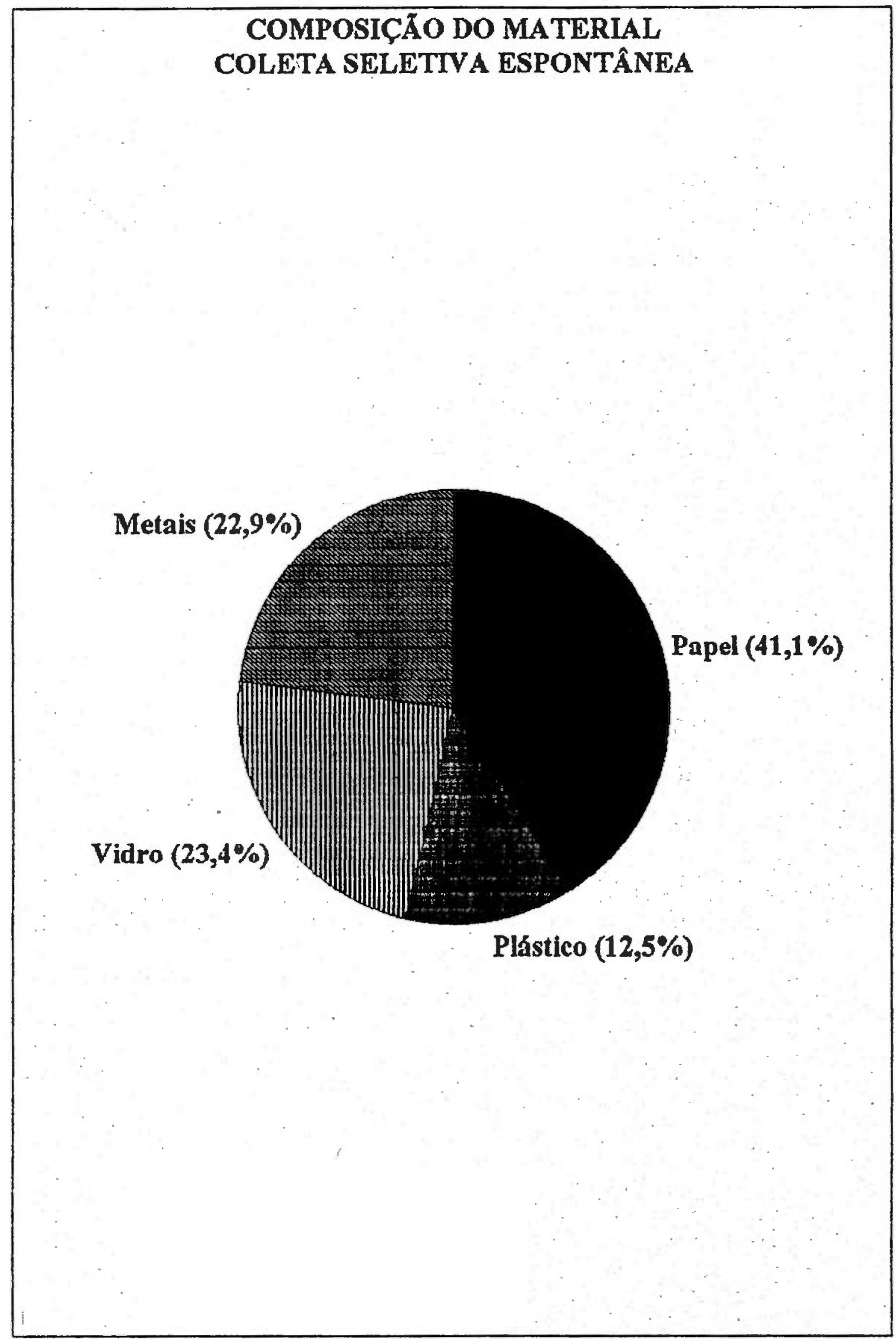

Fonte: DADOS LEVANTADOS COM A COMUNIDADE 
V.6. A EXPERIENCIA DA COOPAMARE/COOPERATIVA DOS CATADORES DE

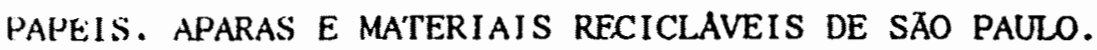

A COOPAMARE/Cooperativa dos Catadores de Papéis. Aparas e Materiais Recicláveis, una cooperativa que congrega os catadores autônomos de papel e materiais recicláveis, foi fundada em 14 de maio de 1989, a partir de algumas experiências de trabalhos comunitários com populações de rua, que haviam possibilitado a fundação da Associação dos Catadores de Papel. em 1985.

A fundação da Associaçāo dos Catadores de Papel teve o obietivo de organizar a categoria dos catadores de papel (estimados em 10.000 no município de São Paulol, e garantir-lhes uma maior protecào jurídica. Essa necessidade de organizacào foj percebida durante o decorrer do trabalho que a OAF/Organizacăo de Auxilio Fraterno lentidade civil sem fins (ucrativos) e religiosos da Fraternidade das Oblatas, da Ordem dos Beneditinos. ligados à Pastoral da Rua. realizaram com a comunidade de rua. Trabalho este que já tinha inclusive dado origem. no final da década de 70. à Comunidade dos Sofredores de Rua .

Estes voluntários se propunham a trabalhar com os moradores adultos das ruas. os problemas 
relacionados com a moradia. trabalho, alcoolismo, entre outros. A fundacão da Associacão foi uma evolucão deste trabalho, uma vez que a "catacão" nas ruas e a venda dos materiais comercializáveis presentes nos residuos urbanos. é quase uma decorrência natural da vida. à margem da sociedade organizada. e no limite da sobrevivência. dessa populacào.

A COOPAMARE surgiu visando combater as irregularidades a que normalmente estão submetidos os catadores de rua. e garantir melhores condicões de trabalho e de vida à esta populaça.

Neste trabalho. definimos catador ou catador de rua, como aquelas pessoas, homens ou wulheres, que recolhem materiais recicláveis nas casas ou ruas e comercializam, servindo portanto como intermediários informais no caminho da reciclagem. Esta nomenclatura foi utilizada porque é a forma que eles decidiram ser a mais adequada . constando inclusive no nome da associacaio e da cooperativa. Nao foram incluídos nesta categoria e neste estudo os "catadores" de lixōes ou vazadouros.

A fundacão da cooperativa teve como objetivo proporcionar um melhor ganho aos catadores cooperados. através de uma comercializacāo em maior escala com a obtenção de melhores precos e da possibilidade de utilização dos equipamentos e caminhoes de propriedade coletiva, assim como $o$ acesso aos locais para concentracão e processamento dos materiais coletados. 
A cooperativa. entretanto. mais do que proporcionar vantagens econòmicas aos cooperados, se propõe valorizar o catador como profissional através da representação desta categoria junto aos poderes públicos e ao mercado de recicláveis. proporcionando ainda assistência jurídica e desenvolvendo cursos de capacitacão profissional, assim como atividades esportivas e sociais.

A COOPAMARE. como sociedade cooperativa, esta aberta a todos os profissionais autónomos catadores de papel e materiais recicláveis. e pratica uma política de identificacão e treinamento de novos sócios. Cada novo associado contribui ao ingressar com $20 \%$ de um salário mínimo. que pode ser pago em até 10 vezes. Esta cota da sociedade não pode ser revendida mas é devolvida em um eventual desligamento do cooperado.

- catador cooperado coleta normalmente os materiais recicláveis, entregando-os para a cooperativa. que os processa e comercializa em condicòes mais favoráveis do que cada catador individualmente. em razáo da escala e da qualidade. o valor da comercializacáo é antecipado ao associado. que tem descontado 10 s cono taxa de administracảo. Quando o catador consegue uma boa quantidade de material. tem o caminhāo disponivel para o recolhimento. tendo descontado neste caso $20 \%$ do valor arrecadado com a venda.

A COOPAMARE tem coletado em média 120 toneladas mensais de materiais reciclaveis. sendo que a maioria 
leste material e constituida por papellfigura 11).Atualmente

conta com 51 cosperados e 2 locais para concentracão e processamento dos materiais coletados. Cada associado consegue com as suas vendas retirar em torno de 2.5 salários mínimos mensais. com al guns chegando a 5 salários minimos.

Estāo sendo procuradas parcerias, como é - caso do trabalho conjunto COOPAMARE/CEMPRE/SENAI-Servico Social da Indústria. visando a produção e a divulgação de um curso que ensina a formar cooperativas de catadores, nos moldes da COOPAMARE.

Fica muito claro no trabalho da cooperativa. que mais do que possibilitar precos mais adequados para os materiais coletados (o que logicamente é fundamental) "existe uma preocupacão com a valorizacāo e a difusão de um codigo de ética dos profissionais catadores". de acordo com Carlos Fabricio ex-presidente da cooperativa. assim como a preocupacão com o "resgate da dignidade do homem de rua e do catador". de acordo com José Amado, atual presidente (gestão $43 / 94$ ). (apacitando tecnicamente e pronovendo atividades sociais. se propōe a atuar de uma forma integral. ampliando os horizontes e aumentando a auto-estima das pessoas envolvidas $(62)$. 
FIGURA 11 - COOPAMARE

\section{COMPOSIÇÃO DO MATERIAL COLETA DOS CATADORES}

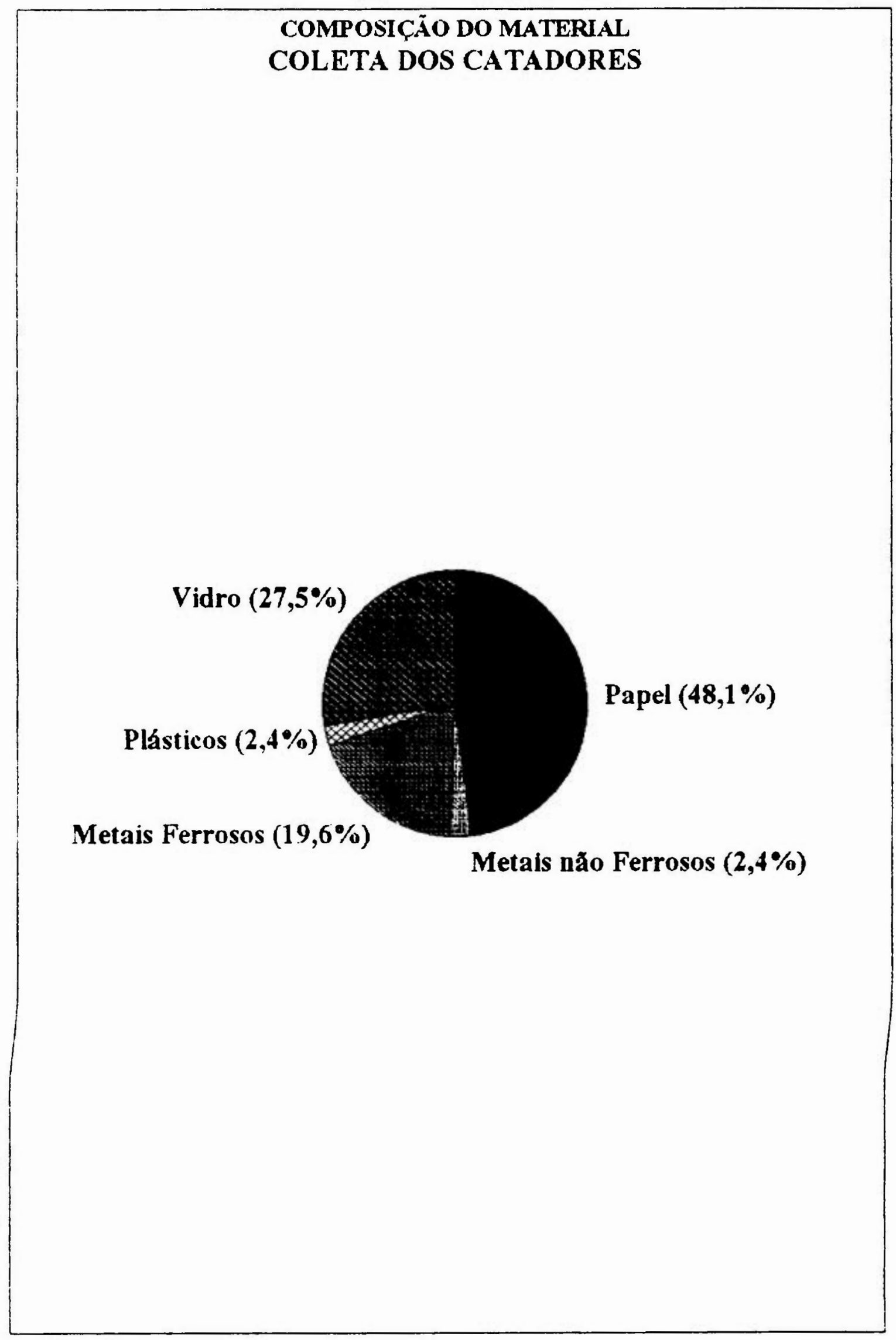


No acompanhamento dos programas de coleta seletiva dos municipios selecionados. e a partir dos resumos destacados nos quadros I e II. encontramos os dados referentes à quantidade de resíduos, material reciclável e rejeito por pessoa; assim como o tipo de metodologia utilizada para a mobilização das comunidades envolvidas. A partir desses quadros sentimos nitidamente a extrema importância do trabalho "corpo a corpo", que acreditamos deveria ser chamado adequadamente de trabalho "pessona a pessoa".

Os quadros I e II mostram que retorno. em termos de quantidade de material coletado por pessoa e de nasor ou menor porcentagem de rejeito. presente no material coletado. está estreitamente associado ao trabalho de mobilização e sensibilizacão realizado com as comunidades envolvidas.

Nas experiências onde a mobilização ocorreu baseada em um trabalho "corpo a corpo". de maior envolvimento com a comunidade. e a partir de atividades propiciadoras de participacão loficinas de papel artesanal. leiras da sucata. gincanas. etcl, houve oportunidades para o 
surgimento de novos hábitos e posturas. assim como para a sensibilizacăo e conscientizaçào, e a consequente percepcão da importancia desse trabalho na prevenção à poluicão e preservação ambiental .

Os programas que obtiveram os melhores desempenhos. em termos de maior quantidade de material coletado por pessoa. assim como menor quantidade de rejeito. foram pela ordem. os desenvolvidos nos municípios de São Sebastião, São José dos Campos. Santos e São Paulo.

Com relacão à quantidade coletada, são Sebastiào demonstrou uma eficiência maior, o que parece ser uma incoerencia. se compararmos a quantidade de material de apoio, principalmente de folhetos, utilizados pelos municípios e a verba gasta em cada programa.

$$
\text { Na realidade. folhetos explicativos }
$$

parecem ter eficiência reduzida. quando dissociados de um envolvimento maior com a questäo. Esta observacào estả de acordo con krancol17) que ressalta ser o "conhecimento pela aplicacão sensivelmente diferente do conhecimento pela explicacão". Citando Court de Jabelin. etmologista do século XVIII. Branco esclarece ter o radical pli. proveniente do celta. o significado de "dobrar. embolotar". Assim. explicar seria tirar as dobras, desdobrar. semelhante ao termo simplificar ldo latim sine-plexus ane é lgual a sem dobrasl. Já aplicar significa "tornar uma coisa aderente à outra. colocar junto". 
Dessa forma o conhecimento pela explicacảo é analitico e invasivo. enquanto o conhecimento pela aplicacào é sintético, integrador.

Com a participação acontece a integração entre os vários componentes envolvidos nas situaçōes, dando margem à novas posturas e atitudes. e para o verdadeiro processo educat ivo.

Na realidade. constatamos que os melhores resultados toram obtidos nos programas onde nos ob.jetivos da implantacão do programa. o componente ambientalista, isto é, a preocupacảo com a prevençāo à poluicão e preservação ambiental era mais forte. Não é por acaso que coordenadoras de dois programas que obtiveram excelentes resultados (São Sebastião e Säo .lose dos Campos), assim como pessoas das equipes técnicas, já desenvolviam trabalhos com a comunidade. ligados a entidades ambientalistas nảo governamentais. antes do início desses programas.

Constatamos. entretanto, por parte das equipes tecnicas de todos os programas. um esforco muito grande, assım como a conviccäo da inportância da realizacão do trabalho educativo envolvendo a comunidade e estimulando a participacão.

Com relacão às experièncias da Favela Wonte Azul e COOPAMARE. chamou-nos a arencảo. a limpeza das instalacoes. a cooperacaio e o alto grau de comprometimento das pessoas envolvidas nas atividades de coleta. Acreditamos que 
proletos integrados deveriam contar com a participacão de experiëncias desse tipo, eficientes, cooperativas e geradas pelas proprias comunidades. Em Ibiporã. no Paraná. uma experiência gerada na biblioteca da cidade e coordenada pela bibliotecária mostrou excelentes resultados $(25)$.

Um ponto que se destaca. e que é constantemente citado nas discussōes sobre coleta seletiva, é o seu alto custo. encontrado com variaçōes, em todos os municípios pesquisados.

Este custo excessivo tem fornecido argumentos àqueles que consideram a coleta seletiva utópica e de dificil realizacão, uma vez que esta demanda toda uma nova estrutura operacional e gerencial, além de depender essencialmente da colaboracào e particjpacão dos geradores dos residuos que, no caso do lixo urbano, compreende toda a populacāo.

Esse alto custo foi. inclusive. o argumento básico da tentativa de desativacão dos circuitos de coleta seletiva do Municipio de São Paulo. pela administracão atual. gerando polémica com a administracào anterior responsável pela implantacảo. Infelizmente. neste caso. as discussōes acabaram enveredando por um caminho politico partidário. desrespeitando as pessoas realmente envolvidas com o programa. tecnıcos da prefeitura municipal e população. 
Consideramos essa atitude antiética e

incompatıvel com o trabalho sério de mobilizacão necessário. no desenvolvimento de proietos ou progranas que dependam do envolvimento e da participacāo de toda a comunidade. e que visem fortalecer novas posturas e comportamentos.

Acreditamos que o projeto de coleta seletiva de São Paulo foi vitima do seu sucesso inicial, e do alto grau de interesse demonstrado pela população nos projetos dessa natureza. O projeto foi iniciado. como projeto piloto, um ano após as primeiras reuniões preparatórias terem acontecido (conforme descricão anteriorl um prazo até longo demais, se levarmos em consideracão que a escolha recaiu sobre um bairro (V.Madalena) considerado "reduto de intelectuais", não representativo da média da populacão da cidade. e, teoricamente. com pessoas iá predispostas à participacăo(35).

A resposta a esse projeto piloto foi considerada boa. uma vez que a coleta de 20 toneladas/mês equivalia a média de 2 quilos por pessoa/mês(tabela 9.gráfico 1 ). E este patamar continuou até maio de 90 , e era considerado um sucesso. apoiado pela populacão e pela mídia(57.61). Este resultado. na realidade. poderia ser muito melhor, uma vez que cada pessoa gera muito mais do que essa quantidade de lixo reciclável por mès. 
Nảo devemos nos esquecer, no entanto, que o fato de um indivíduo pertencer a uma "elite" econômica ou mesmo intelectual. nāo garante a participacāo, pois todos sabemos que so a informacảo adequada nāo predispōe a ação igualmente adequada. Muitas pessoas acabam não participando por "prequica". esquecimento. falta de hábito ou por orientacão inadequada à(s) pessoa(s) responsável(eis) pela manipulacão dos residuos dentro de casa.

De qualquer forma a coleta seletiva obteve sucesso. e a prefeitura sentiu a necessidade de ampliá-la, por conta. inclusive. das pressōes de pessoas interessadas em participar. Pelo gráfico 1 e tabela 9, observamos um aumento de coleta. associado à ampliação do número de circuitos; em abril/maio. de 91 a coleta já alcançava 24.000 domicílios (cerca de 117.000 pessoas $)$ e o número de circuitos continuava a aumentar. envolvendo rapidamente mais 170.000 pessoas a partir de iunho (ponto3)(02.35).

() grático mostra que à esse aumento do numero de circuitos correspondeu uma queda acelerada do retorno. tendo sido coletadas 138.2 toneladas en maio de 4) para um total de aproximadamente 117.000 moradores envolvidos. o que corresponde a cerca de 1.2 quilos por pessoa; enquanto em agosto. para aproximadamente 287000 moradores coletou-se 212.55. o que equivale a aproximadamente 0.75 quilo por pessoa. 


$$
\text { Em outubro de } 1992 \text { já existiam } 37
$$

circuitos de coleta, abrangendo 110.000 residências e cerca de 500:000 pessoas, e foram coletadas 254,52 toneladas, o que corresponde a 0.5 quilo por morador.

$$
\text { Fica nitido que o retorno e a }
$$

participacảo da populacāo atendida decresceu proporcionalmente à ampliacão do número de circuitos.

Se, para o início do projeto piloto, foram necessarios praticamente 12 meses de trabalho, com uma populacão iá considerada mais receptiva (prazo que consideramos excessivol. como em 30 meses a mesma equipe e a mesma estrutura de triagem e comercializacão poderiam dar conta da ampliacão e do envolvimento de mais 488.000 pessoas?

E quando o custo da coleta seletiva leva em conta a infra-estrutura necessária para a coleta e comercializacảo nesses 37 circuitos (com custos médios mensais de US\$ 67.820)(35) e a participacão da populacão é pequena. fica claro que este investimento é exagerado.

Contudo. fica claro também. que este foi un momento analisado. a partir de apenas um parâmetro. Certamente n projeto cresceu além da conta. revelando um desequilíbrio. que deveria levar à um rearranjo. que possibilitasse. a partir do estudo dos outros paràmetros envolvidos. a busca de solucōes inovadoras. 
ou até a algumas solucōes iá previstas no projeto inicial. e nunca implantadas, como a Instalacão de um segundo centro de triagem (57). assim como outros centros. já que. de acordo com o CEMPRE. uma das razōes do alto custo. foi o grande número de circuitos em diferentes pontos da cidade, distantes do Centro de Triagem(02).

Esse projeto, que assim como a própria cidade se mostrou grande demais para a sua pequena estrutura. revelou falhas, como consequência imediata do interesse da populacão em participar, e da prefeitura em atender. sem estrutura adequada. à demanda. De acordo o Campos $(24)$. programas dessa natureza devem ter um planejamento estratégico que leve em conta, e enfatize. a importância do trabalho de reforco que deve ser feito com a populacão. visando a participacão constante. e não apenas um envolvimento inicial. na etapa de implantacão.

A diminuição da taxa de retorno aconteceu. pela impossibilidade do atendimento quase que individual, observado quando da implantação do projeto. gerando queixas. inclusive pelo rádio ou iornal. de pessoas que reclamavam do esquema de comunicacāo da prefeitura com as comunidades envolvidas.

Eram comuns as manifestacāo a respeito de mudancas nảo comunicadas do dia de coleta, assim como da ausència de notificacão quando da interrupcào da entrega dos 
sacos de papel. Reclamavam ainda do desconhecimento do destino da verba auferida pela venda dos produtos. uma vez que a informacão inicial era de que ela reverteria para a comunidade, como aconteceu na V.Madalena. que chegou a receber abrigos de ônibus adquiridos com esse dinheiro.

Alguns detalhes simples, como por exemplo. o desconhecimento de que uma pilha usada não é considerada "metal" assim como um guardanapo sujo não é considerado "papel", para este tipo de coleta, pode interferir, tanto aumentando a porcentagem de rejeito. quanto diminuindo a participação, uma vez que uma dúvida não resolvida pode levar à desistência.

Portanto, acreditamos que en programas desta natureza, é fundamental a escolha da equipe técnica adequada. assim como apoio politico e investimentos suficientes para que o trabalho com a populacāo decorra sem solucão de continuidade. e tenha condicōes de ser eficiente e produtivo.

Ainda com relacão ao custo da coleta seletiva faz-se necessário ressaltar que ele é normalmente discutido de forma isolada. sem que sejam levados em consideracao todos os outros componentes e benefícios gerados por projetos desta natureza. que proporcionam oportunidades de participacão e mobilizacão dos vários setores envolvidos.

Essa impossibilidade de avaliacão de todas as vantagens adicionais geradas pelos programas de coleta seletiva. nas várias prefeituras onde elas foram 
Implantadas, tem sido citada em vários textos e relatórios, tanto por representantes de prefeituras $(06,15)$ quanto pelos estudos do CEMPRE $(01.02 .69)$.

Também normalmente não são sequer mencionados os altos valores desembolsados pelas prefeituras municıpais. para custero de todo o servico de limpeza urbana. coleta e destinacão dos resíduos.

No município de São Paulo cerca de $3 \%$ do orcamento é destinado para este fim (tabela 10). ficando em torno de US\$ 172 milhöes em 1991. e esse valor é considerado normal. Gasta-se com a varricão e limpeza das ruas quase a metade do que é gasto com toda a coleta domiciliar dos resíduos urbanos, e este fato também é considerado normal.

Fica nitido que existe em alguns setores, uma visáo parcial da situacāo, além de extrema dificuldade no investimento em proietos não tradicionais. e que envolvam componentes educativos. e nao o uso de tecnologias complexas ou a realizacan de grandes obras.

Fica muito claro que projetos deste tipo nao podem ser proietos estanques. desarticulados do todo e quantitativamente analisados, a partir de um enfoque clássico de custo/beneficio. onde leva-se em consideracão. muitas vezes. apenas os aspectos e o retorno. de um ponto de vista exclusivamente económico. 
So ol hando o todo. podemos valorizar cada parte de um complexo sistema. E o sistema global envolvendo a questáo dos residuos gerados por uma cidade. talvez seja o mais complexo de todos. porque ele é. na realidade. o retrato da nossa sociedade pós industrial.

Para Odum(51): A cidade industrializada é un ecossistema incompleto ou heterotrófico. dependendo de grandes áreas externas a ele para a obtenção de energia. alimentos, libras, áqua e outros materiais. Esse sistema apresenta: 1) um metabolismo muito intenso por unidade de área exigindo um influxo muito grande de energia concentradalatualmente suprida, na maior parte por combustíveis fósseis (, 2) uma grande necessidade de entrada de materiais, como metais. para uso comercial e industrial acima e além do necessário para a sustentacào da própria vida; e 3) uma saída maior e mais venenosa de resíduos. muitos dos quais são substâncias químicas mais tóxicas do que os seus precursores naturais.

Concluindo, ele argumenta que para esse ripo de ecossistema. os ambientes de entrada e saída são relativantente multo mais importantes do que no caso de um sistema autotrofico. como uma floresta.

Quando trabalhamos os resíduos sólidos de un sistema urbano. temos uma excelente oportunidade de estudar esses ambientes de entrada e saida, uma vez que estes funcionam como a radiografia das necessidades e 
dos desequalibrios de todo esse complexo.

Alguns pesquisadores americanos já trabalham como "arqueologistas" dessa sociedade, escavando antizos lixöes e aterros. na busca de informações a respeito dos hábitos e padrões de consumo, a partir da qualidade e quantidade do material descartado(34,45).

E verdade que os resíduos urbanos não sảo os mais importantes. mais volumosos ou tóxicos resíduos sólidos produzidos. mas săo os que mais espelham o desequilíbrio dos nossos atuais padröes de uso e descartel 19$)$.

Inclusive. nào podemos nos esquecer que grande quantidade dos outros resíduos sólidos gerados pela sociedade (resíduos industriais, agrícolas, de mineração, etc), também estāo int imamente ligados a esse modelo. excessivamente consumista e descartável(18.20).

Acreditamos na necessidade de ' se trabalhar holisticamente a questão dos nossos residuos. Holismo. è um termo cunhado. em 1926. pelo filósofo sul-africano Jan Smuts. para designar a tendencia do universo para construir unidades que formam um todo de complexidade crescente(16). Em 1967. Arthur Koestler também um dos pioneiros da abordagem holistica desenvolveu o conceito de "holon". para designar elemencos que funcionem parcialmente como todos. ou em coniuntos como partes. de acordo com o àngulo pelo qual são contemplados(47). Para o teólogo Leonardo Boff (16) holismo 
"significa o esforço de surpreender o todo nas partes e as partes no todo". De uma forma simplificada acreditamos que significa, ter a percepcão do todo nas partes e das partes no todo. Esta visão holística é portanto sintética e integradora, capaz de ordenar, organizar, regular e finalizar as partes no todo e cada todo com outro ainda maior (16).

De acordo com Crema(33), nos horizontes ampliados da consciencia numana esta surgindo uma nova cosmovisào que representa para ele, o mais significativo evento histórico dos últimos séculos, posteriores à Renascenca. Alicerçada na visao nolistica ela reintegra o homem à natureza e propoe uma re-evolução na cultura humana, uma vez que de acordo com Yung "o conceito que formamos a respeito do mundo é a imagem daquilo que chamamos mundo. E é por essa imagem que orientamos a adaptaçāo de nós mesmos à realidade" (33).

De acordo com Branco (17) é o equipamento de conhecimentos e crenças, denominado cultura, que nos difere dos outros animais, e é a própria evolucão cultural humana. um magnitico exemplo de atuaçao integrada, coordenada e precisa de um sistema, neste caso, do sistema nervoso central. Branco nos relembra que para piaget, o nosso sistema nervoso é muito mais do que um complexo agregado de células e reflexos, que enquanto entidades físicas isoladas, não tem absolutamente a propriedade de raciocinar, esta propriedade só surge em função do estabelecimento de inter-conexões ordenadas e adequadas, numa estrutura extremamente complexa formada por esses elementos indispensáveis. 
Esta estrutura extremamente complexa, de funcionamento preciso. nos remete inclusive. à importância do equilibrio entre as diversidades. Recentes pesquisas em neurotisiologia experimental demonstram que, embora o cérebro funcione como um circuito integral. seus dois hemisférios possuem luncoes distintas. 0 hemisferio cerebral esquerdo, que controla o lado direito do corpo é responsável pelo controle de nossas funcōes cognitivas verbais, de raciocinio e lógica formal e linear. Determina ainda a realizacão das funcões analíticas ligadas ao uso da palavra. da abstracão, classificacão e comparacao. estando mais ligado às experiências passadas. 0 hemisfério direito é a sede de nossas funçōes de compreensão, de intuicäo. captacào de padrōes, de imagens, de melodias, de poética. de gestalts e de totalidade. estando mais ligado ao inusitado e ao desconhecido. o corpo caloso. espesso feixe de nervos const ituido por milhöes de fibras, interliga esses dois hemistérios. equilibrando o racional ao intuitivo. o conhecimento a compreensao. a analise a sintese: levando da parte ao todo. do passato ao presente e vice versa.1271. A resolucào de problemas complexos em circunstancias novas requer a atividade dos dois hemisférios cerebrais. Sem a analise racional do hemisfério esquerdo nảo conseguimos saber se os padrōes captados pelo lado direito sào reais ou imaginários mas em compensação. a mera analise racional e critica sem o brilho da criatividade e o vıslumbre da intuicão se mostra estéril e imobilizante. 
Urge que aprendamos a utilizar esse nosso imenso potencial na busca das solucōes para todas as grandes crises da atualidade, entre estas. as crises ambientais. E necessária a reaval iacào da nossa relacào com o tempo e com os ciclos naturais (23). Como foi destacado anteriormente. o excesso de geração de residuos è um marcador incontestável de uma sociedade em desequilibrio. e requer portanto solucöes criativas, muitas vezes nào covencionais. 


\begin{tabular}{|c|c|c|c|c|}
\hline \multicolumn{5}{|c|}{$\begin{array}{l}\text { QUADRO } 1 \\
\text { RSTDUOS URBANOS DE COLETA NORMAL } \\
\text { OS MUNICIPIOS RSTUDADOS. }\end{array}$} \\
\hline MUNICTPIOS & \multirow{2}{*}{$\frac{\text { Sxo }}{\text { SEBAASTIXo }}$} & \multirow{2}{*}{$\begin{array}{c}\text { SXo JOsE } \\
\text { DOS CAMPOS }\end{array}$} & \multirow[b]{2}{*}{ SANTOS } & \multirow[b]{2}{*}{ SAO PAULO } \\
\hline CARACTERTSTICAS & & & & \\
\hline Populagio & 40000 & 462540 & 117000 & 10000000 \\
\hline $\begin{array}{l}\text { Total de Reidnos } \\
\text { Colatado } \\
\text { (ton/dia) }\end{array}$ & 45 & 250 & 120 & 13000 \\
\hline $\begin{array}{l}\text { Populagio Atendida } \\
\text { pela Coleta Seletira }\end{array}$ & 15000 & 58224 & 170000 & 500000 \\
\hline $\begin{array}{l}\text { Quantidade de } \\
\text { Materisl Colatado } \\
\text { Va Coleta Scletira }\end{array}$ & 1.5 ton/di2 & $3.5 \mathrm{ton} / \mathrm{diz}$ & \& ton'diz & loton/dia \\
\hline Cnto (dGlar / toB) & $\cdots$ & 181 & 372 & 391 \\
\hline $\begin{array}{c}\text { Qunitidado } \\
\text { Pencardia (Q) }\end{array}$ & 100 & 60,1 & 23,5 & 20 \\
\hline $\begin{array}{l}\text { Rejeito da Coleta } \\
\text { Seletiva } \\
(\% \text { no total })\end{array}$ & -- & 3 & 4 & 8,5 \\
\hline
\end{tabular}

Fonte: PRERIITURA MUNICIPAL DR SAO SRRASTIXO ( 14) CRMPRE (01,02,69) 


\begin{tabular}{|c|c|c|c|c|}
\hline $\begin{array}{r}\text { METODOLOG } \\
\text { APOIO U }\end{array}$ & $\begin{array}{l}\text { LA DE MOBIIZ } \\
\text { TIZADOS NOS }\end{array}$ & $\begin{array}{l}\text { QUADRO } 2 \\
\text { ACגO, ATIVID } \\
\text { MUNICtPIOS B }\end{array}$ & $\begin{array}{l}\text { DRS R MATERIAL } \\
\text { TUDADOS. }\end{array}$ & DR \\
\hline \begin{tabular}{|c|} 
MUNICIPIOS \\
\\
CARACTRRISTICAS \\
\end{tabular} & $\frac{\text { SAO }}{\text { SKBASTIRO }}$ & $\begin{array}{c}\text { SXo JOSE } \\
\text { DOS CAMPOS }\end{array}$ & SANTOS & glo PAULO \\
\hline $\begin{array}{l}\text { Metodologia de } \\
\text { Mobilizapio }\end{array}$ & $\begin{array}{l}\text { "corpo } 2 \text { corpo" } \\
\text { rouniöos com } \\
\text { a comnnidado }\end{array}$ & $\begin{array}{l}\text { "corpo } 2 \text { corpo" } \\
\text { visitzs } \\
\text { domiciliares }\end{array}$ & $\begin{array}{l}\text { divilgado por cam } \\
\text { panbas publicitírias } \\
\text { an ridios e jornais }\end{array}$ & $\begin{array}{l}\text { rauniöes com } \\
\text { moradores ou } \\
\text { represent andes }\end{array}$ \\
\hline Metorial do Aprio & $\begin{array}{l}\text { slidese "muits } \\
\text { conven" }\end{array}$ & $\begin{array}{l}\text { folbutos } \\
\text { radilifveis }\end{array}$ & $\begin{array}{l}\text { faixonoflecos de } \\
\text { rus merigi infor- } \\
\text { mativo nos onibus }\end{array}$ & folbetoe \\
\hline Uso de Polbetoe & סקומ & varios & varios & vários \\
\hline Cartllhe & 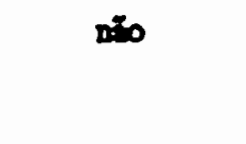 & $\begin{array}{l}\text { simfdidribuide } \\
\text { an rode do } \\
\text { caino }\end{array}$ & $\operatorname{sim}$ & סא \\
\hline $\begin{array}{l}\text { Nome da Campanba } \\
\text { Pernonagem Simbolo }\end{array}$ & $\cdots$ & $\begin{array}{l}\text { "OLuro do } \\
\text { Liro" } \\
-\infty\end{array}$ & $\begin{array}{l}\text { "Liso Limpo" } \\
\text { "Sr. Olimpo" }\end{array}$ & $\cdots$ \\
\hline $\begin{array}{l}\text { Distriugigo de } \\
\text { Sacos Pláticose }\end{array}$ & nos & กี๊० & مבמב & $\begin{array}{l}\text { ( } 4 \text { primoiras } \\
\text { sermmas) }\end{array}$ \\
\hline $\begin{array}{c}\text { Oficinas de Papd } \\
\text { Artexamed }\end{array}$ & $\sin$ & $\cdots$ & $\sin$ & مدّ \\
\hline $\begin{array}{l}\text { Paime Com unititias } \\
\text { de Sncata e Bagulbo }\end{array}$ & $\sin$ & $\cdots$ & $\cdots$ & nבี \\
\hline $\begin{array}{c}\text { Gincanas e Pegas } \\
\text { Teatrais }\end{array}$ & $\cdots$ & $\ldots$ & $\operatorname{sim}$ & ถลี \\
\hline $\begin{array}{l}\text { Poatoe de Coleta } \\
\text { Voluntiria }\end{array}$ & $\begin{array}{c}\operatorname{sim} \\
\text { (parzos quatro } \\
\text { moterixis) }\end{array}$ & $\begin{array}{c}\operatorname{sim} \\
\text { (scmente vidro) }\end{array}$ & $\operatorname{sim}_{\text {(somente vidro) }}$ & $\underset{\text { (parzos quatro }}{\text { moterizis) }}$ \\
\hline
\end{tabular}

Focte: PRRP. MUNICIPAL DR SAO SRRASTIXO (14) CRMPRE $(01,02,69)$ 


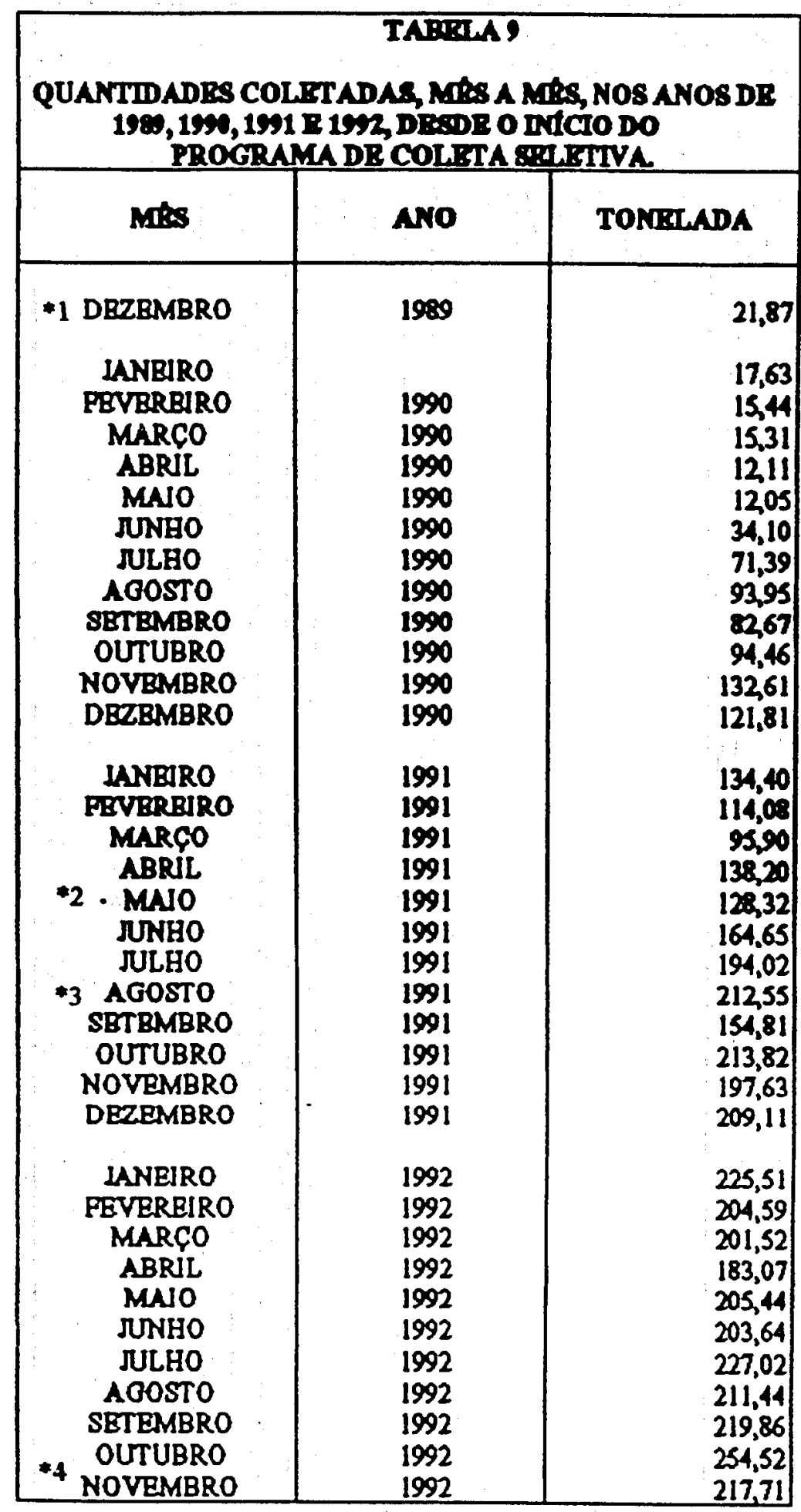

- 1 Coles em 2 circuitos -3.500 resid. -12.000 moradores

- 2 Colda am 10 circuitos - 24.000 revid. - 117.000 moradaros

- 3 Colda en 19 circuitos - 58.000 rovid. - 287.000 moradores

- 4 Colda am 37 circuitos - 110.000 resid. - 500.000 moradores

Fonte. CEMPRE (02) 


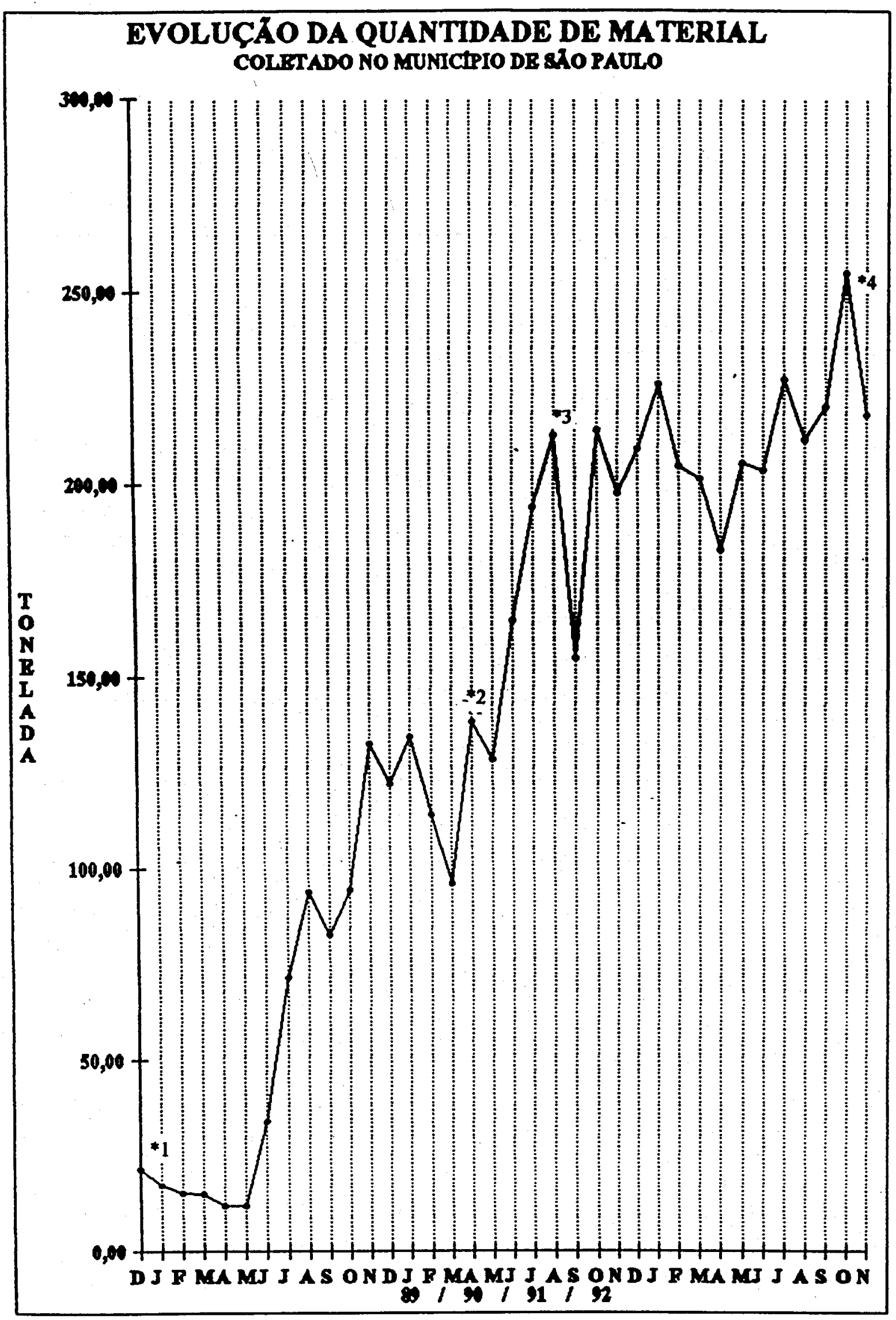

Fode: CEMPRE (02) 


\begin{tabular}{|c|c|c|c|}
\hline \multicolumn{4}{|c|}{$\begin{array}{l}\text { DASPESAS COM LIMPERA URAANA } \\
\text { NO MUNICIOIO DE SAO PAULO 1988/91 }\end{array}$} \\
\hline ANO & $\begin{array}{l}\text { VOLUML } \\
\text { Millies de } \\
\text { Tondada) }\end{array}$ & $\begin{array}{l}\text { VALOR } \\
\text { (USS nilliea) }\end{array}$ & \% ORCAMIMTIO \\
\hline 1988 & 4,66 & 68 & 2,4 \\
\hline 1989 & 3,69 & 193 & 3,9 \\
\hline 1990 & 3,86 & 169 & 4,4 \\
\hline 1991 & 4,24 & 172 & 3,2 \\
\hline
\end{tabular}

Fonte: CALDERONI (22) 
VI. CONCLUSOES

113 
- trabalno com a coleta seletiva. alicercado no valor ambiental da reciclagem dos materiais descartados após consumo. é fundamental na busca de uma nova dinâmica homem-ambiente-natureza.

Na medida que envolve $e$ busca a participacáo de cada pessoa. cria condicōes de esclarecimentos que possibilitam questionamentos e reflexöes. Saber que un simples papel leva três meses para ser degradado nue lugar úmido. e que para iornais ea condicōes de pouca umidade essa degradação pode demorar décadas(ver anexo II Superinteressante/julho/1993) pode ser extremamente educativo. Inclusive porque esse material. quando visto pelo aspecto derradabilidade parece não afetar de forma aito séria o ambiente.

$$
\text { Mais esclarecedor e educativo ainda é }
$$

saher que um simples chiclete pode demorar 5 anos. uma embalagem de metal ferroso mais de 10 anos. enquanto plásticos e vidros levariam. respectivamente. centenas e milhares de anos para retornar aos ciclos naturais.

Desta torma. mais do que desviar materiais recicláveis do seu destino irrevogável, de na melhor das hipóteses. Ser destinado a um aterro sanitário. a coleta seletiva deve estar fundamentada na mudança de comportamentos e at itudes das pessoas envolvidas.

Devem, portanto. ser tomadas precaucōes 
capazes de impedir que estes programas ou projetos se transformem apenas em atividades do tipo "separa e vende", que podem até funcionar de imediato, mas que efetivamente não acrescentam, em termos de modificação dos muitos hábitos e atitudes, que estão se mostrando incompatíveis com a preservação dos recursos naturais para o futuro e com a busca do desenvolvimento sustentável; práticas estas tão comuns nessa nossa "era do descartável", de acordo com o historiador Vance Packard(19).

E portanto fundamental que as pessoas participantes estejam realmente sensibilizadas e inteiradas das vantagens ambientais de uma nova postura, com relação ao seus modos de vida e hábitos diários, e engajadas na busca de mudanças que engloben uma nova consciência dos residuos produzidos, e uma tomada de posicão em direção à minimização, e portanto. à redução na origem, reutilização e reciclagem, destes resíduos.

Aprender a perceber que todo 0 plástico, por exemplo, já produzido no planeta e não reciclado, ainda permanece disposto, provavelmente de forma inadequada, em algum lugar, parece-nos muito útil. Inclusive por que o início da produção deste material ainda não completou 100 anos, e o seu uso intensivo só ocorreu nas duas ou três últimas décadas.

A noção de necessidade e importância da coleta seletiva e da reciclagem de residuos oferece oportunidades para o re-contato do indivíduo, principalmente daquele dos grandes centros, com a grande lição que os ciclos naturais nos passam, a lição da continuidade e perenidade que faz parte da 
própria essência da vida.

E relembrar que a vida è perene, remete-nos à uma via de respeito e ética com nossos semelhantes, e com cada constituinte dessa teia vital.

A própria Comissão Mundial para o Meio Ambiente e Desenvolvimento da ONU, no documento "Cuidando do Planeta Terra " publicado em 1991(73), coloca claramente o papel essencial e básico da ética e do respeito à vida, na busca do desenvolvimento sustentável.

Uma abordagem holística no desenvolvimento desses programas e projetos, parece-nos o único caminho viável a ser seguido, de modo a permitir o envolvimento das pessoas e o exito real destes.

Thomas Tanner (72) registra no livro, "Educação Ambiental, a polêmica a respeito de qual caminho a educação deve trilhar, o caminho cognitivo ou o afetivo, registrando as impressões de uma série de educadores.

Parece-nos impossível essa separação, uma vez que, em uma sociedade tão complexa como a nossa, sem 0 domínio do conhecimento formal, não poderemos chegar à dinâmica do funcionamento das partes que compõem este todo, e consequentemente, ficaremos à margem de um posicionamento crítico, comprometendo o nosso livre arbítrio, e a tomada de posições realmente conscientes, no nosso dia a dia. 
Mas sem o domínio afetivo, sea ut ilizarmos o lado direito do nosso cérebro. jamais chegaremos ao respeito e à ética. e a um profundo entendimento da vida.

Entretanto. nossa sociedade calcada no mecanicismo(27). coloca claramente fronteiras entre esses dois dominios e. citando novamente Tanner. mesmo aqueles que enfatizan a necessidade do desenvolvimento de "atitudes e valores positivos" (expressão com uso frequente en currículos escolares) resistem ao emprego do termo amor".

Na realidade. cada vez mais. as pesquisas mostram que tudo é uno no Universo, não existe antagonismo entre 0 saber e o sentir, was sim complementaridade. $(17.27)$.

Pesquisas recentes demonstram que a própria memorizaçāo do aprendido esta ligada ao conteúdo afetivo do momento do aprendizado. Quando estamos envolvidos afetivamente con a situacão. o nosso cérebro funciona em uma frequência de onda. que facilita a retençào destes novos conhecimentos(64).

Quantos de nós iá desenvolvemos profundo interesse por matérias ou disciplinas durante a nossa vivencia acadèmica. ou por temas durante o decorrer da nossa vida. mr encontrarmos professores ou dessoas apaixonadas pelo que laziam. capazes portanto de transmitir e multiplicar essa paixào? 
E muito comum na área ambiental autores considerarem a necessidade de estudarmos essa questão a partir de uma abordagem holistica, global. integrada.

0 que se faz urgente é que, não só os estudos. mas as acöes se.jam holfsticas. Que nestas as pessoas se iam tratadas como seres individuais e únicos, capazes de evolucāo. desde que se acenda a chama do entendimento e da compreensão. Está mais do que na hora de pararmos de fazer grandes projetos que envolvam individuos distantes e desconhecidos, que chamamos genericamente de "povo". Na realidade todos os projetos são produzidos e desenvolvidos por pessoas (que além das suas habilidades técnicas, polfticas ou didáticas, possuem famílias, amores, dores, desencontros, encontros, filhos, etcl, para outras pessoas. que são seus senelhantes. Todo ser humano é único e merece ser tratado como tal. A busca das solucōes coletivas numa prática holística passa pela valorizacão da acảo de cada parte deste todo coletivo. Se a populacão humana cresce cada vez mäis e se existem previsões de que os problemas coletivos. ambientais ou nào. crescerão. torna-se premente que aprendamos a enxergar, nesse todo, além dos problemas. as centelhas das solucōes.

As práticas holísticas sāo interativas e pressupöem acōes conjuntas e cooperativas realizadas por pessoas. Náo mais erandes obras projetadas e desenvolvidas por grandes especialistas. para usufruto do "povo". mas sim projetos e programas integrados, onde todos as pessoas envolvidas, de una 
lorma ou de outra. sintam-se bem, seja criando. planejando. construindo ou usando.

Como nos diz Albert Canus(04): "Já se disse que as grande idéias vêm ao mundo mansamente como pombas. Talvez. entảo. se ouvirmos com atencão, escutaremos, en me io ao estrépito de impérios e nacöes. no discreto bater de asas, o suave acordar da vida e da esperanca. Alguns dirão que tal esperanca iaz numa nacāo: outros, num homem. Eu creio, ao contrario. que ela é despertada, revivificada, alimentada por milhỏes de individuos solitários, cujos atos e trabalho. diariamente. negam as fronteiras e as implicaçöes mais cruas da história. Como resultado. brilha por un breve momento a verdade, sempre aneacada. de que cada e todo homen. sobre a base de seus próprios sofrimentos e alegrias, constrói para todos". 
VII . RECOMENDACOES 
Relembrando as conclusỏes do I Seminário de Avaliacảo de Experiências de Coleta Seletiva de Lixo, que foi realizado no Rio de Janeiro em 1992, gostariamos de reforçar que a coleta seletiva nảo é panacéia para a resolucão de todo o problema dos resíduos sólidos, e que esta deve ser um dos elos de um sistema integrado de gerenciamento de residuos sólidos.

Entretanto, ela é fundamental como fator mobilizador e ideal para a prática de un dia a dia consciente, e para o trabalho de integracão homem-cidadão-natureza.

$$
\text { Recomendamos que, nos projetos de }
$$

coleta seletiva, se trabalhe holișticamente. não esquecendo que esta é uma forma de levantarmos a questão da inconsequência de muitos dos nossos atos cotidianos.

Faz-se necessário que os pro.ietos de coleta seletiva. este.jam integrados a trabalhos que "limpen o lixo" da visão preconceituosa de que. por ser extremamente sujo e teio.. deve ser rapidamente descartado e ignorado.

Que seiam seguidos os exemplos das preteituras ou associacoes que implementam of icinas de papel artesanal. realizam exposiçōes e daquelas que organizam feiras. gincanas ou atividades que estimulam a participacão de adultos e criancas.

oue seiam prestigiadas iniciativas como as do artista plástico Washinton Santana(ver anexo II.capa do seu Iivro"A arte do Lixo") que realiza obras de arte con lixo, 
demonstrando que o belo esta en toda a parte, é só uma questāo de aprender a enxergar. E a história tem wostrado o papel lundamental da arte e dos artistas. para a revisão do antigo na busca de novas formas de enfrentamento de problemas. Acreditamos. portanto que a arte e os artistas são nossos parceiros naturais, e trabalhos coniuntos devem ser buscados. Um exemplo de arte popular citando a relacão entre a exploracāo predatória da natureza, o luxo e o lixo, foi dado pela Escola de Samba Vai Vai, no carnaval de 1993 (anexolI).

A aídia, que tanto auxilia a geração de resíduos. estimulando o consumo, deveria divulgar e se envolver com as soluçöes, ajudando a diminuir a distância entre o técnico da área ambiental. o educador e o grande público. Exemplo excelente de entendimento e preocupacão com a questão foi dado por Jô Soares na Revista "Veia" de 13/01/93. Onde este se assombrou com o tamanho do problema dos resíduos de uma cidade. mesmo acreditando e tendo citado erroneamente que a.producão de resıduos urbanos das Sào Paulo e Rio de Janeiro. é da ordem de 1. iun toneladas diárıas(ver anexo 111 .

E finalmente, seria extremamente produtivo que as igreias se envolvessem com a questão. não desperdicando essas excelentes oportunidades de discussāo da ét ica e do sagrado. embasados no profundo respeito que devemos a natureza e ao eio em que vivemos. Nessa direcão está caminhando o destacado trabalho do ISER e de Enilio Eigenheer em Niterói. no Rio de Janeiro. onde o Centro de Informaçōes sobre 
Residuos Sólidos da UFF/Universidade Federal Fluminense/ISER utiliza cartazes, assim como outros materiais de divulgaça e apoio aos projetos de minimização de resíduos, utilizando mensagens bíblicas(ver anexo II).De acordo con Capra(28), a percepçāo ecolórica e a percepçāo espiritual fluem juntas, e reciclar. pela possibilidade de pernitir a percepcão da existènc $a$ dos ciclos naturais. pode ser considerada uma prática espiritual.

Como contribuição à essa busca de solucōes holísticas envolvendo a questão dos resíduos e a questão ambiental. estamos apresentando no anexo I. nosso trabalho. denominado Projeto Arco íris Brasil. que visa propiciar e buscar, esse rever e esse repensar. "liapando o lixo" e desenvolvendo ações $e$ materiais de apoia que trabalhen con.juntamente os nossos resíduos, o consumo e a ética. 
VIII . REFERENCIAS BIBLIOGRAFICAS 
1) ALBOREDA. S. Relatório do Estudo CICLOSOFT em S. José dos Campos. CEMPRE. Rio de Janeiro. 1993.

2) Al.BOREDA S. Relatório do Estudo CICLOSOFT em São Paulo. CEMPRE. Rio de Janeiro, 1993.

3) Alonso, L. R. Gestão Ambiental en Säo Paulo : A questão dos Resíduos Sólidos. 10 Seminário de Gestāo e Tecnologias de Tratamento de Resíduos, São Paulo, 1991.

$4)$ ALVES, R. Conversas com quem gosta de ensinar Cortez Editora. Sâo Paulo, 1992.

5) AMAZONAS, M. Reciclagem de Embalagens. IAPRI 8th World Conference on Packaging. Sāo Paulo. 1993.

6) ASSIS. V. Luxo do Lixo - A Experiência de São José dos Campos. Prefeitura Municipal de são José dos Campos, 1992.

7) ASSOCIACÃO BRASILEIRA DE NORMAS TECNICAS. NBR 9896. Glossário de Poluicão das áquas. São Paulo. 1993.

8) ASSOCIACAO BRASILEIRA DOS FABRICANTE DE PAPEL E CELULOSE. A Reciclagem de Papéis. São Paulo. 1991.

9) ATBIAV/ABIVIDRO . Reciclagem de Vidro. I Encontro de Gerentes. São Paulo, 1991.

10) BANCO MUNDIAL Desenvolvimento e Meio Ambiente Relatório sobre o desenvolvimento Mundial. Fundacảo Getúio Vargas. Rio de Janeiro. 1992.

11) BARCIOTTE. M.L. Disk Reciclagem Bhrama. Geonac Eng. Rio de Janeiro. 1994. (no prelo). 
(2) BATALHA. B. Glossário de Engenharia Ambiental. Ministério do Interior/Secretária Especial do Me io Aabiente. 1988.

13) BERMANN. C. O Circuito do Alumínio e a Hidroeletricidade. Departamento de Energia Instituto de Eletrotécnica e Energia da Universidade de São Paulo. Sāo Paulo. 1993.

141 BLAUTH. P.R. Alguns dados sobre a coleta Seletiva de Lixo em São Sebastiāo. Prefeitura Municipal de São Sebastião. São Sebastião, 1992.

15) BLAUTH, P.; GONÇALVES, G. Separaçāo domiciliar de lixo: por un destino final desde o início. Revista Cepan, ano I número 4. São Paulo, 1991.

16) BOFF. L. Ecologia Mundialização Espiritualidade. Editora Atica. São Paulo, 1993.

17) BRANCO. S. M. Ecoss istêmica - Uma Abordagem Integrada dos Problemas do Meio Ambiente. Editora Edgard Blucher Ltda, São Paulo. 1989.

181 BROHN. L. R.(org) Oualidade de $\nabla$ ida 1990/Salve o Planeta. Worldwatch Institute. Editora lobs. Sáo Paulo. 1990.

19) BROHN. L. R. (Org) Qualidade de Vida 1991/Salve o Planeta. Worldwatch Institute. Editora Globo. Sảo Paulo. 1991.

20) BROkN. L.R.(org) Qualidade de Vida 1992/Salve - Planeta. Worldwatch Institute. Editora Globo. Sāo Paulo. 1992.

21) BRONN. L.R.(org) Qualidade de Vida 1993/Salve - Planeta. Worldwatch Institute. Editora Globo. Sào Paulo. 1993. 
$22)$ CALDERONI, S. Projeto de Pesquisa para a elaboração de Tese de DoutoradoPerspectivas Econômicas da Reciclagea do Lixo no Município de São Paulo. FFLCH/Universidade de São Paulo. São Paulo. 1993.

231 CAMPOS. M. D. Fazer o Tempo e 0 Fazer do Tempo : ritmos em concorrência entre o ser humano e a natureza. Ciência e Ambiente, Santa Maria/I juí . 1994.

24) CAMPOS.R.D. Proposta de Sistematização e reavaliação de gerenciamento de serviços de coleta seletiva de resíduos sólidos domiciliares. Dissertacão de mestrado. Escola de Engenharia de ?São Carlos/Universidade de São Paulo. São Carlos, 1994.

$25)$ CARDIN, T. M. S. ; FERNANDES,F.; SILVA, S. M. C. P.; BACARIN, A. Soluções Alternativas para Inplementaçāo da Coleta Seletiva de Resíduos Sólidos em Pequenas Comunidades. Caso do Município de Ibiporä / PR. I Congresso Lat ino-Americano de Resíduos Sólidos. São Paulo. 1993.

261 CAREAGA. J. Mane jo y Reciclage de Resíduos de Envase y Embalage-Caso de La Ciudad de México. IAPRI/8th World Conference on Packaging. Săo Paulo.1993.

$27)$ CAPRA. F. O Ponto de Mutacão. Editora Cultrix.São Paulo.1882.

$28)$ CAPRA. F.: STEIDEL-RAST. D. Pertencendo ao Universo. Editora Cultrix. São Paulo, 1991.

$29)$ CETEA/Seminário Embalagem e Meio Ambiente. Campinas. 1990.

301 CETEA/Seminário Embalagem e Heio Ambiente. Campinas. 1992. 
$31)$ CETESB -Curso básico para Gerenciamento de Sistemas de Resíduos Sólidos.CETESB.São Paulo. 1982.

32) COLPAERT.H. Metalografia dos produtos siderúrgicos comuns. Editora Edgard Blucher Ltda. 1989, São Paulo.

33) CREMA. R. Introdução a visão holística Summus Editorial. São Paulo. 1988.

$34)$ DOW PLASTICS. Who"s Responsible For this Mess? USA. 1991.

35) EIGENHEER, E. M.(org) Coleta Seletiva Experiências Brasileiras. UFF/ISER/GTZ. Rio de Jane iro, 1993.

36) EPA/USA-UNITED STATES ENVIRONMENTAL PROTECTION AGENCY. Caracterization of Municipal Solid waste in the USA. USA, 1990.

37) EPA/USA-ENVIRONMENTAI PROTECTION AGENCY. Waste Minimization Opportunity Assessment Manual. EUA. 1988.

38) EPA/USA-ENVIRONMENTAL PROTECTION AGENCY . Decision-Makers Guide to Solid Waste Management. USA. 1989.

$39)$ ESCOLA DO LIVRO/BIENAL DO LIVRO. Educação Ambiental e Reciclagem de Lixo. Câmara Rrasileira do Livro. São Paulo. 1992.

40) EUROPEAN PACKAGING NEWSLETTER AND WORLD REPORT. International Packaging Club. v. 25, n.6. Paris. 1992.

411 ELROPEAN FACKAGING NEWSLETTER AND WORLD REPORT. International Packing Club. v. 25, n. 8. 1992. 
42) FERREIRA. A.B.H. Novo Dicionário Aurélio Editora Nova Fronteira. Rio de Janeiro, 1975.

43) FIGUEIREDO. P.J.M. Os residuos sólidos e sua significacão frente ao impasse ambiental e energético da atualidade. Tese de Doutoramento. UNICAMP. Campinas, 1992.

44) GANAPINI,W. A reciclagem de lixo na Europa . Seminário Internacional Indústria e Meio Ambiente. INTER/CETESB/FUNDAP. São Paulo, 1992.

45) GORE.A. A Terra a procura de equilíbrioecologia e espírito humano. Editorial Presenca. Lisboa, 1993.

46) FREEMAN. H. M. Hazardous Waste Minimization-A Strategy for Environmental Improvement. Waste Management. volume 38 número 1, 1988.

$47)$ KOESTER. A. O Fantasma da Máquina. Zahar Editores. Rio de Janeiro. 1969.

481 MENEZES. L.V.T.:STRAUSS E.L. Minimização de Residuos. XVII Congresso Brasileiro de Engenharia Sanitária e Ambiental. Natal: 1993.

49) NELS.C. - Waste Minimization in the Federal Environmental Agency Berlin. 10 Sem. Int. de Gestäo de Tecnologia de Tratamento de Resíduos. Sāo Paulo.1991.

501 OBLATH. R.M. - The Use of Recycled Poliester in Packaging. IAPRI/8th World conference on Packaging. Sào Paulo.1993.

51) ODLM.E. P. Ecologia. Interamericana. São Paulo. 1985 . 
52 ) OLIVEIRA. W.E. WITT, V.M. (org.) Saneamento do Lixo. Lixo e Limpeza Pública.Faculdade de Higiene e Saúde Pública-USP/OMS/OPS.

São Paulo.1969.

53) OLIVEIRA,W.E. Resíduos Solidos-Relacão com o homem e o ambiente.CETESB/Companhia de Tecnologia de Saneamento Ambiental.São Paulo.1976.

54) PLASTIVIDA - Plástico servindo toda a vida. São Paulo.1992.

55) PREFEITURA MUNICIPAL DE PORTO ALEGRE. OS Caminhos do Lixo - da origem ao destino final. I Simpósio Latino-Americano de Resíduos. São Paulo, 1993.

56) PREFEITURA MUNICIPAL DE SXO JOSE DOS CAMPOS São José Verde e Limpa/Prograna de Educação Ambiental.São José dos Campos, 1992.

571 PROJETO RECICLAGEM. ano I. número 1.Almagesto Editorial. São Paulo. 1990.

58) FROJETO RECICLAGEM. ano I. número 2.Almagesto Editorial. São Paulo. 1990.

59) PROJETO RECICLAGEM. ano II. número 3.Almages to Editorial. São Paulo. 1991.

60) PROJETO RECICLAGEM. ano II. número 4.Almagesto Editorial.São Paulo.1991.

611 PROJETO RECICLAGEM, ano II, número 5.Al magesto Editorial.São Paulo.1991.

62) PROJETO RECICLAGEM. ano II. número 6.Almages to Editorial.São Paulo.1991. 
63) PROLATA. Lata de Aço - Conserva até a natureza. Sindicato das Indústrias de Estamparias de Metais do Estado de Sāo Paulo. São Paulo, 1994.

64) RIVAS.0.S. Uma abordagem holística no conhecimento e desenvolvimento humano. Congresso Holistico Internacional de Canela.Canela.1992.

65) REINFELD,N.V. (org) Sistemas de Reciclagem Comunitária - Do Projeto à Administação. Mackron Books. São Paulo. 1994.

66) ROCHA.A.A. A História do Lixo. Resíduos Sólidos e Meio Ambiente no Estado de São Paulo/Secretaria de Estado de Meio Ambiente. São Paulo, 1993.

67) SCHWARZ,L.B. - Plastic Recycling in Brasil Present Perspectives. IAPRI/8th World Conference. São Paulo, 1993.

68) SECRETARIA DA CULTURA DA PRESIDENCIA DA REPUBLICA - Transformando e recriando os restos: 0 Lixo Passado a Limpo. Inst. Bras. de Patrinonio Cultural.Rio de Janeiro. 1992.

69) SILVEIRA.G.T.R. Relatório do estudo CICLOSOFT em Santos.CEMPRE.Rio de Jane iro. 1993.

70) STRAUSS. E.L.: MENEZES. L.V.T.: POFFO.I.: BARCIOTTE. M. L. Coleta Seletiva de Papel em Escritórios. II Seminário Internacional sobre os Problemas Ambientais dos Centros Urbanos/ECOURBS. São Paulo. 1993.

71) SOUZA E SILVA.M.J.- Gestão de Resíduos Sólidos na Cidade de São Paulo. Seminário Internacional de Gestāo e Tecnologia de Tratamento de Residuos. São Paulo. 1991. 
72) TANNER. R.T. Educacăo Ambiental. Summus/Edusp. Sảo Paulo. 1978.

73) UICN/PNUMA/WWF Cuidando do Planeta Terra/Uma Estratégia para o futuro da Vida.Governo do Estado de São Paulo. Rio de Janeiro, 1992.

$74)$ WEIL. P. Nova Linguagem Holística. Editora Espaco e Tempo/CEPA. Rio de Janeiro, 1987. 
ANEXO I 


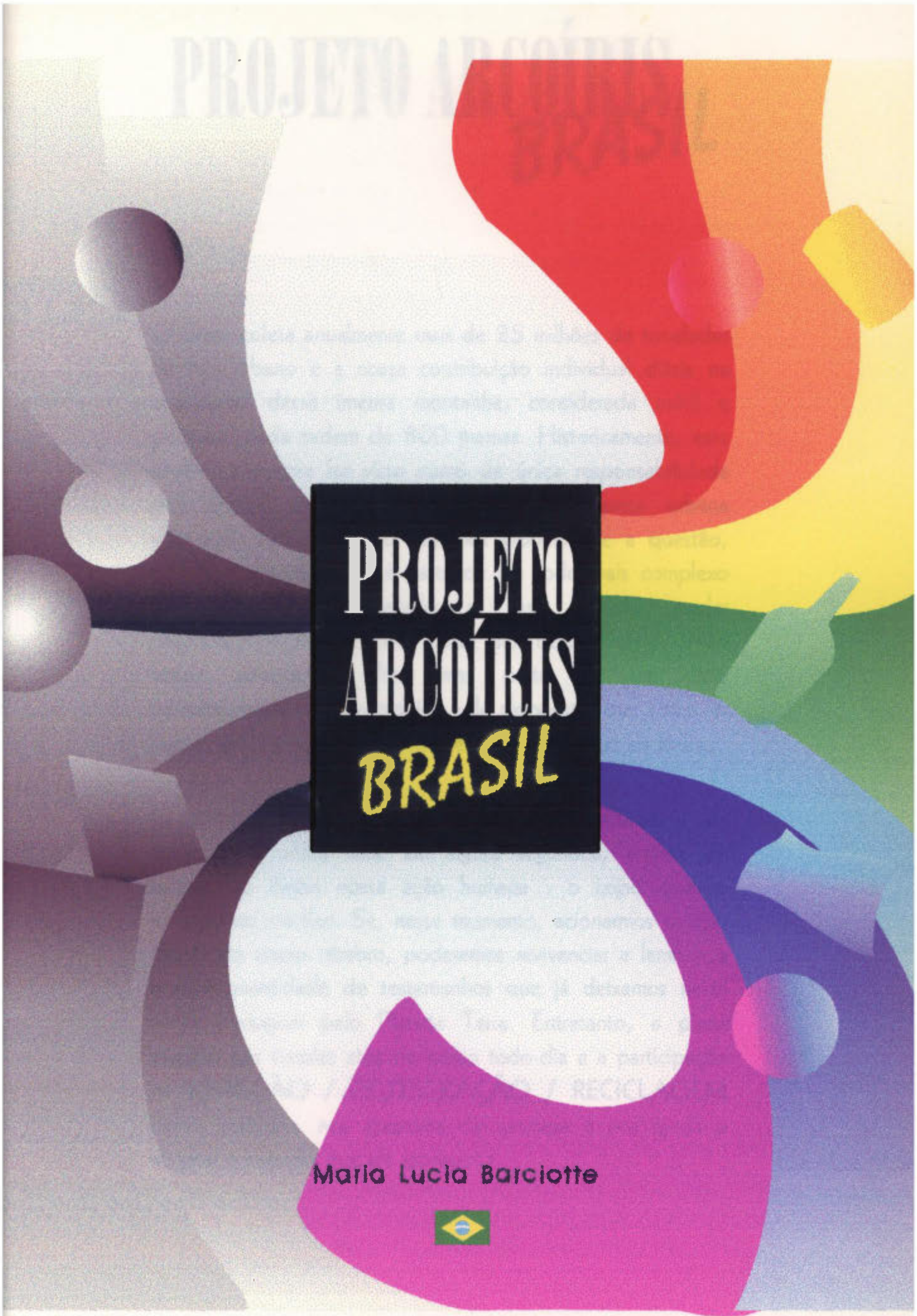




\section{PROJETO ARCOÚRISL BRASIL}

$\cup$ Brasil coleta anualmente mais de 25 milhões de toneladas de lixo urbano e a nossa contribuição individual diária na construção dessa imensa montanha, considerada inútil e perigosa, é da ordem de 800 gramas. Historicamente, este problema sempre foi visto como de única responsabilidade dos órgãos públicos encarregados da limpeza urbana municipal. Entretanto, ao olharmos globalmente a questão, percebemos que o lixo é parte de um todo mais complexo que deve ser reavaliado e que 0 seu poder didático/transformador não pode ser desperdiçado. Não sendo considerado fim, mas parte de um ciclo momentaneamente interrompido, ele demonstra que todas as nossas ações têm consequências e estão integradas ao todo.

O simples ato de abrirmos um copo descartável e de matarmos a nossa sede em alguns segundos, origina um testemunho dessa nossa ação humana : o copo que se transformou em lixo. Se, nesse momento, acionarmos o lado direito do nosso cérebro, poderemos revivenciar e lembrar a imensa quantidade de testemunhos que já deixamos nesta nossa passagem pelo Planeta Terra. Entretanto, a plena atenção aos simples atos do nosso todo-dia e a participação na REDUÇÃO / REUTILIZAÇÃO / RECICLAGEM destes resíduos, nos aproxima da natureza e nos ajuda a resgatar o sagrado que ela representa. 
O símbolo do ARCO-IRIS é usado de modo a ligar a imagem do belo e do poético que ele sugere à imagem do trabalho com a redução do lixo, coleta seletiva e reciclagem, buscando alterar a visão cultural de "lixo" ou "resíduos" descartados como "sujeira", o que dificulta a participação comunitária e a destinação adequada do material reciclável.

O ARCO-IRIS é usado também para passar a visão de ciclagem natural dos elementos e para ressaltar que a reciclagem possibilita economia de matéria prima, de água e energia e de espaços para a disposição final dos resíduos. Desta forma, fazemos a ligação entre a preservação da natureza, a responsabilidade de cada um no seu cotidiano e a beleza do signo utilizado.

O PROJETO ARCOÍRIS - BRASIL visa informar e facilitar a participação efetiva de cada um de nós na resolução do problema "lixo doméstico" e para isso utiliza as cores já convencionadas e usadas em diferentes cidades do Brasil e do mundo (caso do amarelo, verde, azul e vermelho) ou aquelas ainda não utilizadas (caso do laranja, violeta $e$ índigo), para diferenciar os vários tipos de resíduos que podem ser reciclados. Desta forma usamos :

vermelho $\Leftrightarrow$ plástico
laranja $\Leftrightarrow$ lixo orgânico
amarelo $\Leftrightarrow$ metal
verde $\Leftrightarrow \Leftrightarrow$ vidro
azul $\quad \Leftrightarrow$ papel
índigo $\Leftrightarrow \Leftrightarrow$ resíduos tóxicos
violeta $\Leftrightarrow$ para os "lixos" de todos nós




\section{ETAPAS DO PROJETO}

Elaboração de um Projeto Editorial (livro) onde o lixo doméstico e as diferentes etapas dos processos de reciclagem dos materiais que o constituem serão alvo de fotos de arte com o objetivo de informar (a partir de fotos e textos explicativos), dissociar RESÍDUO $=$ LIXO de sujeira, associando os materiais potencialmente recicláveis a MATÉRIAS PRIMAS e portanto, o retorno ao ciclo, fortalecendo a importância da RECICLAGEM, e a volta da "Lei de Lavoisier" a algumas das nossas atividades.

Elaboração e organização de palestras, cursos e seminários, a serem ministrados ou desenvolvidos em diferentes níveis e para diferentes segmentos da sociedade, sobre os temas:

desenvolvimento sustentado

consumo e consumo sustentado

desperdício

ética prevenção à poluição minimização de resíduos coleta seletiva reciclagem

Produção de material de apoio (vídeos, transparências, slides, folders, histórias em quadrinhos, etc) a serem utilizados por entidades e/ou pessoas interessadas, via empréstimo, locação ou doação.

Organização de eventos envolvendo RESÍDUOS, ARTE E MEIO AMBIENTE, sempre utilizando o ARCO-IRIS como elo de ligação. 
ANEXO II 
CICLO DO PLÁSTICO

POPULAÇÃO
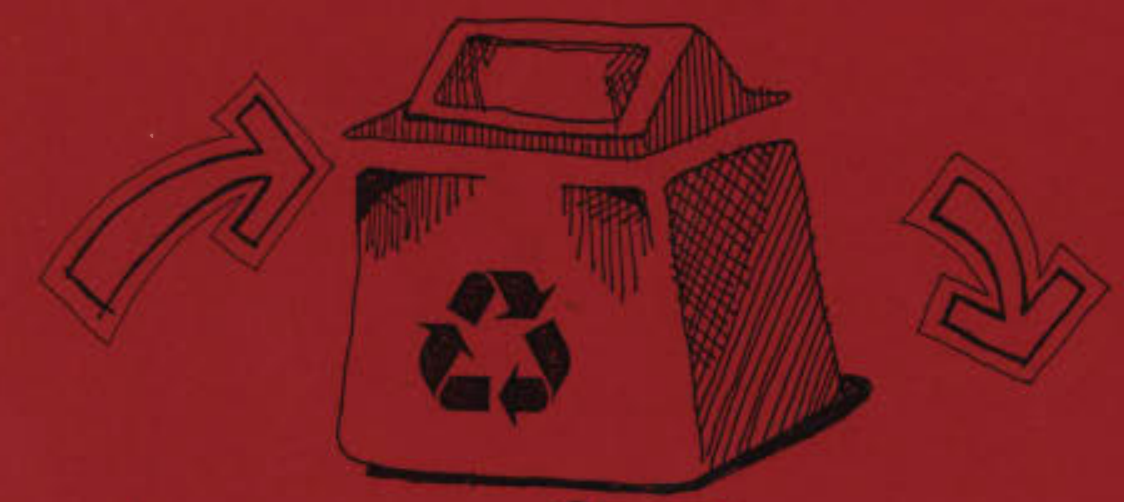

COLETA

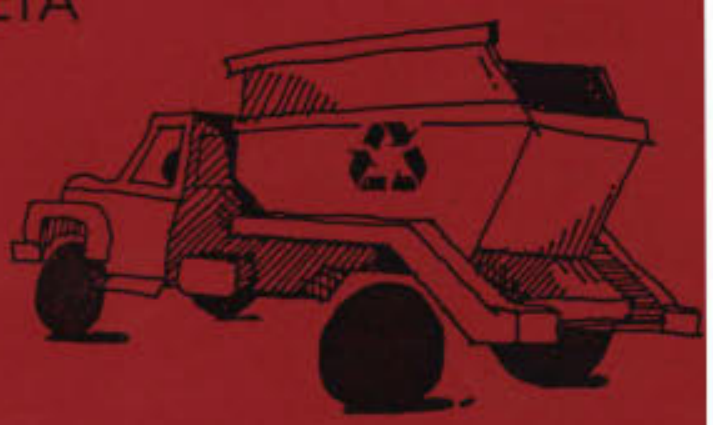

TRANSPORTE
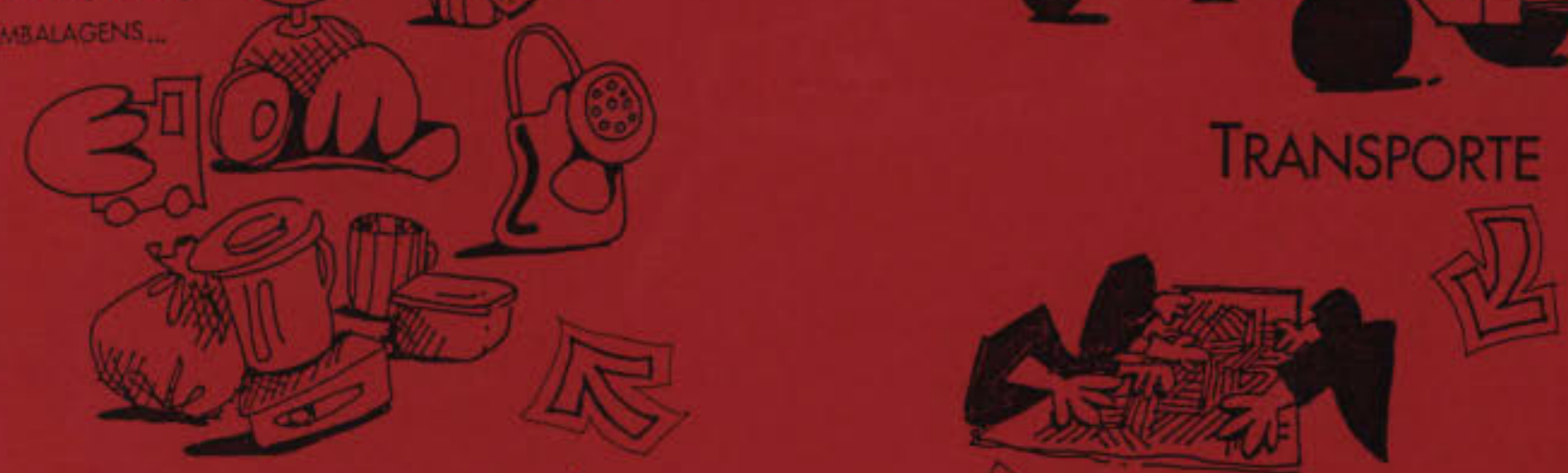

$$
\begin{aligned}
& \text { INDÚSTRIA } \\
& \text { TRANSFORMADORA } \\
& \text { DEMATERIAIS PLASTICOS }
\end{aligned}
$$

CONDUTITES, TUBOS,

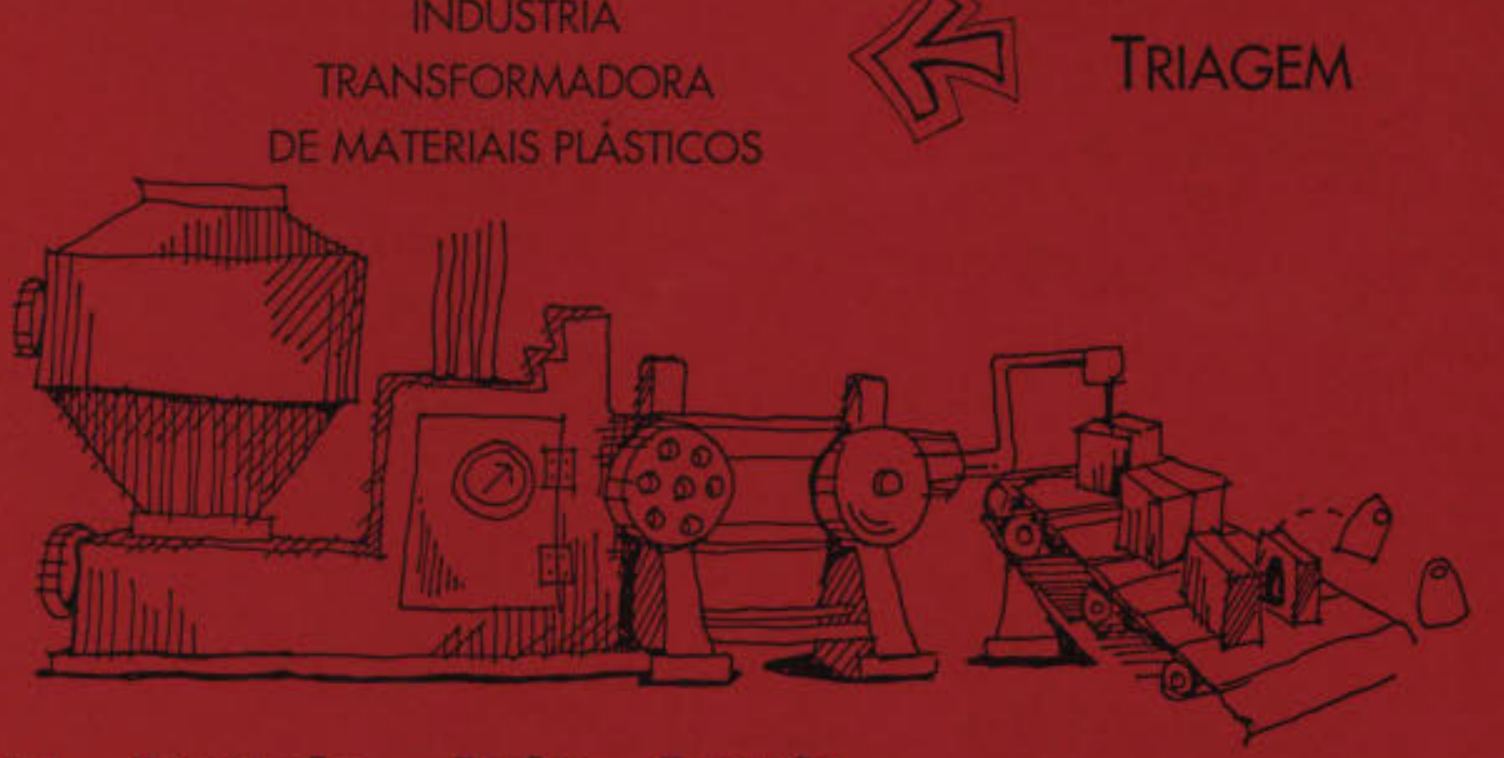

LIMPEZA - TRTURACCĀO $=$ FUSĀO $=$ EXTRUSÃO

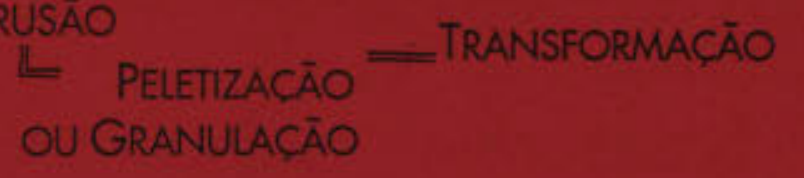




\section{CILLU UU MEIAL}

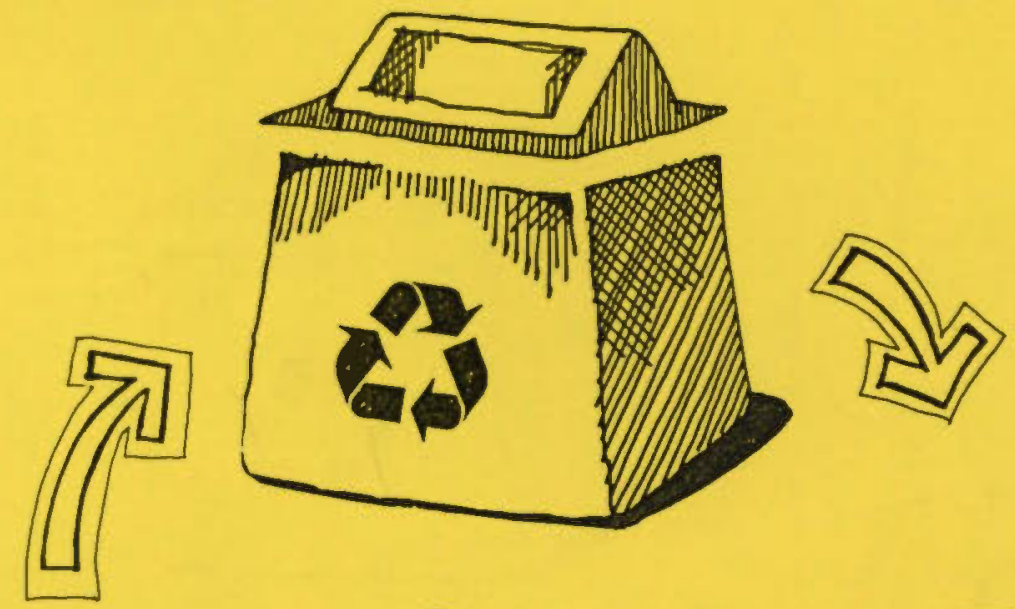

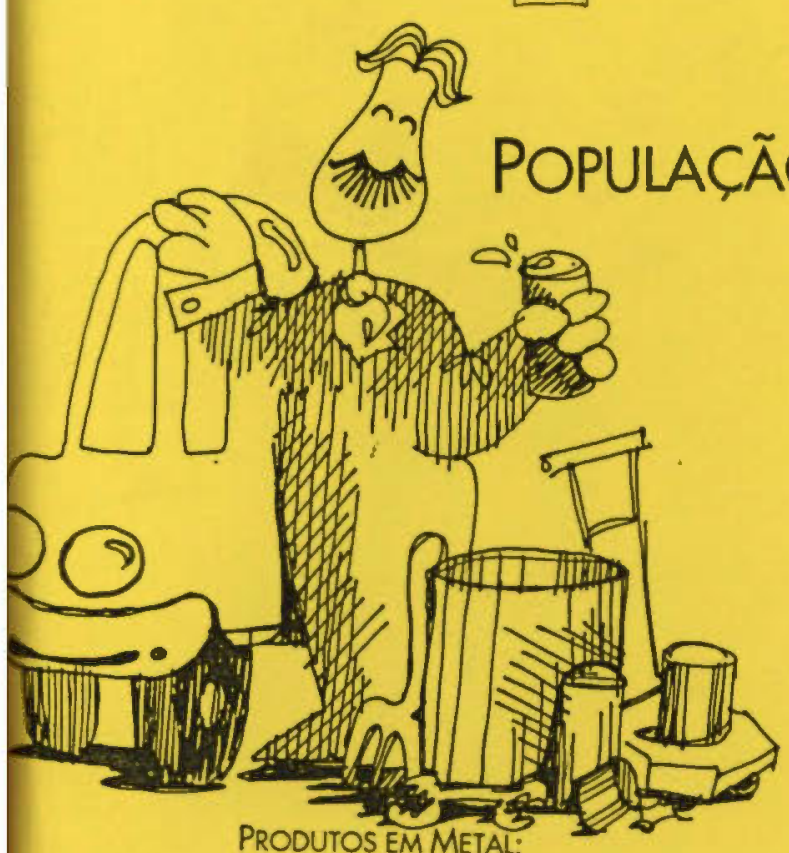

PRODUTOS EM METAL

ATAS DE REFRIGERANTE, CERVEAA (ALUMINIO) E DE ALIMENTOS, NTAS (FOLHA-DE-FLANDRES/ AÇO), OBJETOS METÁUICOS,...
COLETA

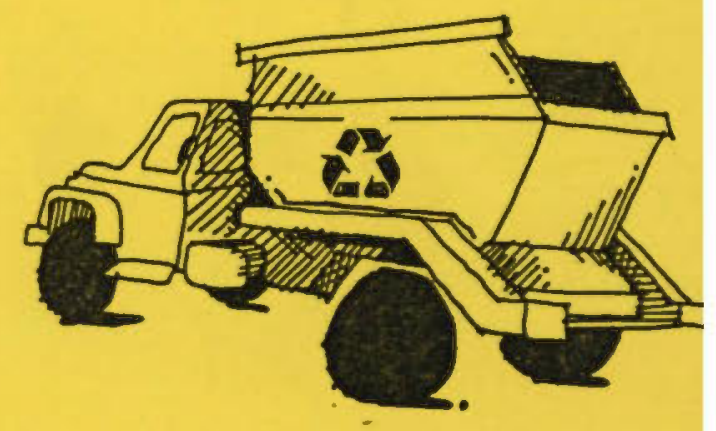

TRANSPORTE

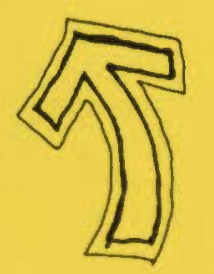

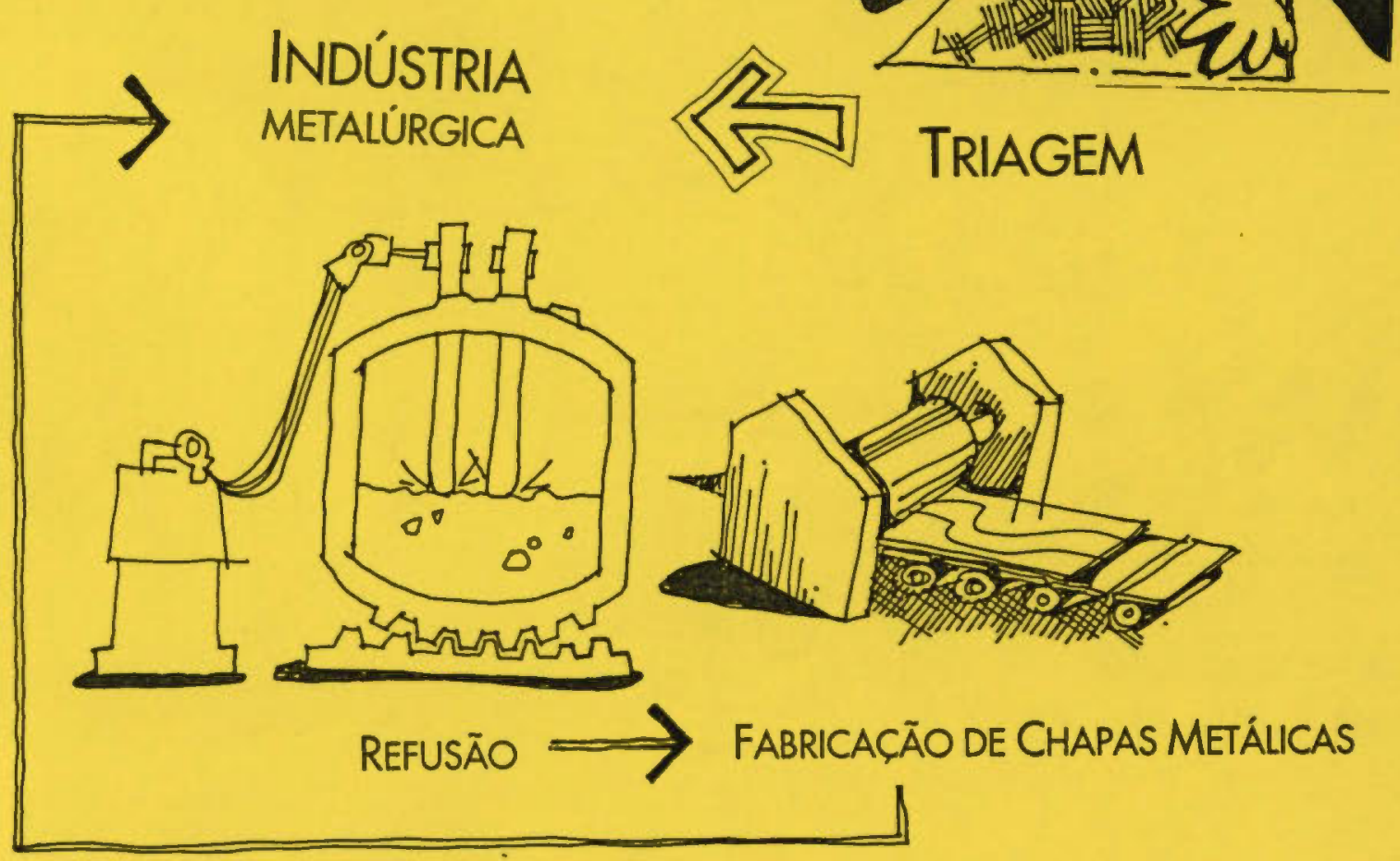




\section{CICLO DO VIDRO}

POPULAÇÃO
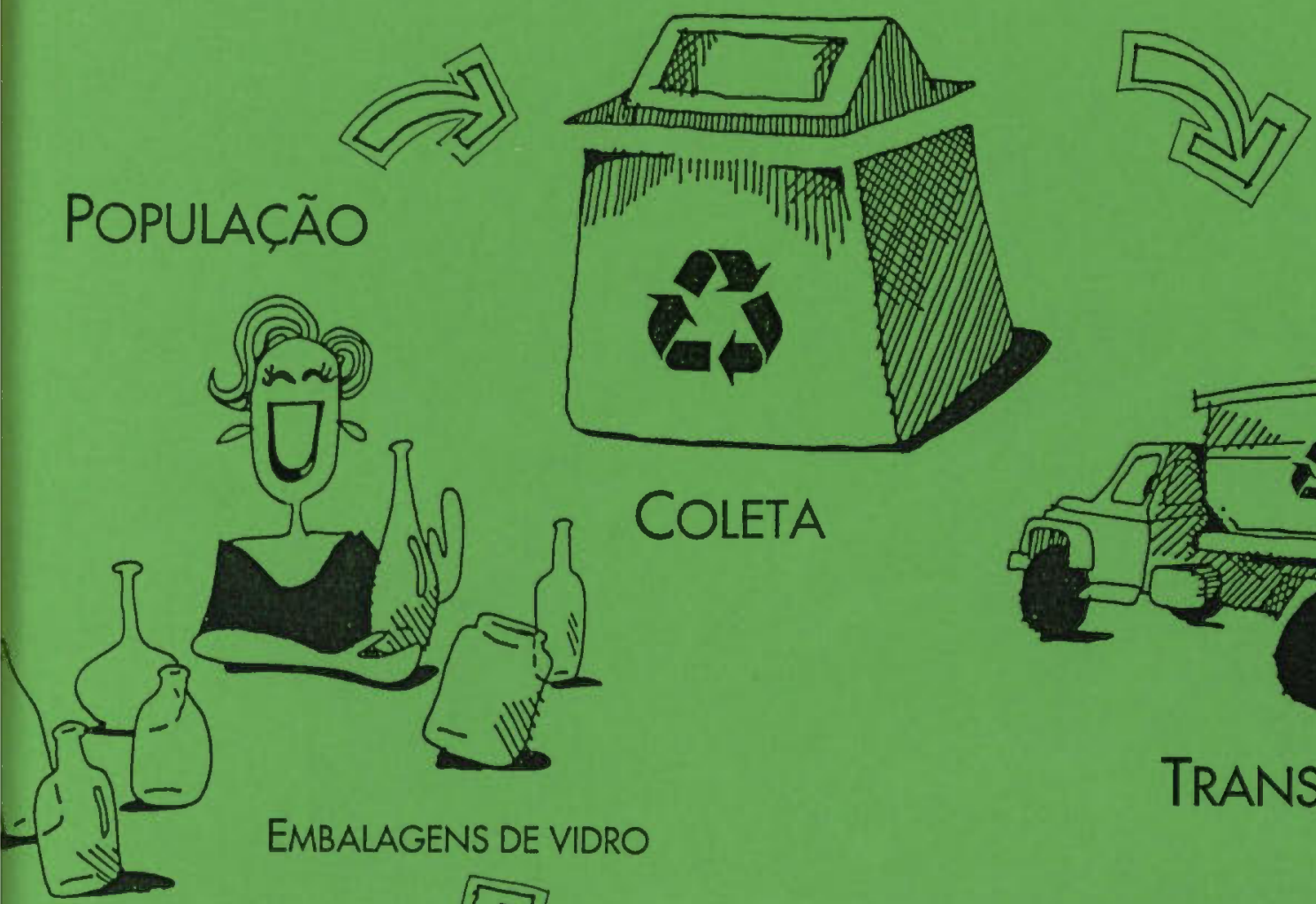

EMBALAGENS DE VIDRO

$$
\text { जि }
$$

INDÚSTRIA
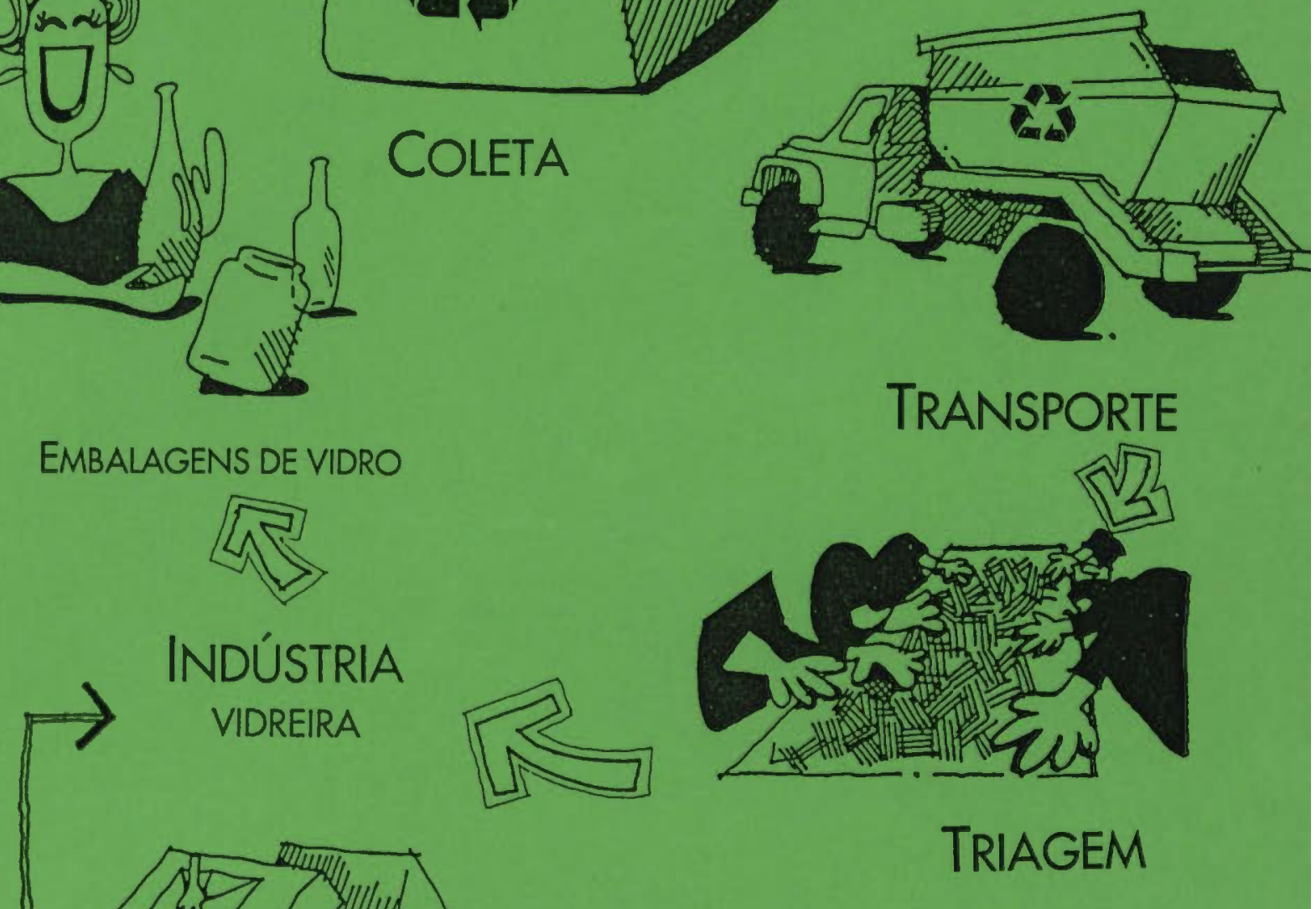

TRANSPORTE
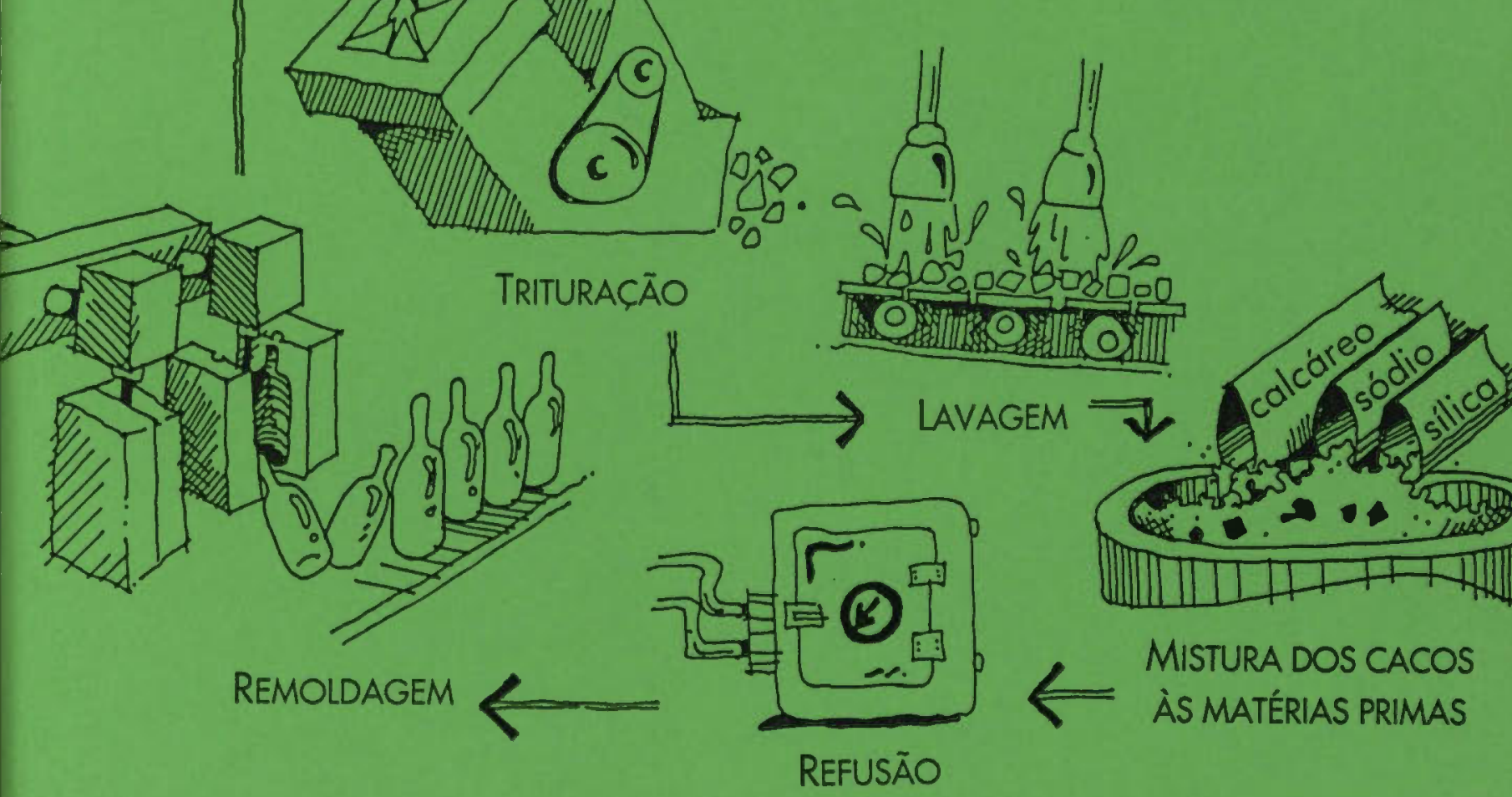


\section{CICLO DO PAPEL}

PAPEl RECICLAdO OU MISTO: EMBALAGENS,

CADERNOS, ...

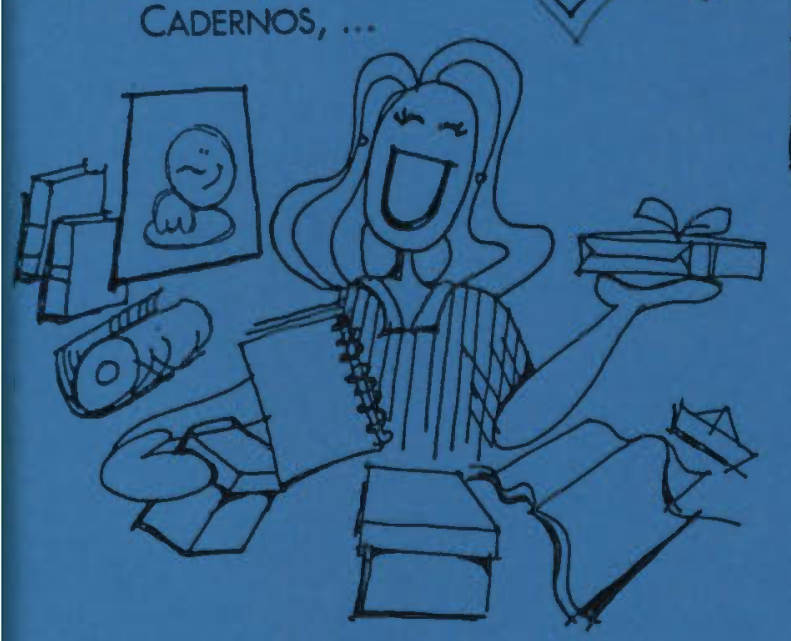

POPULAÇÃO<smiles>c1ccccc1</smiles>

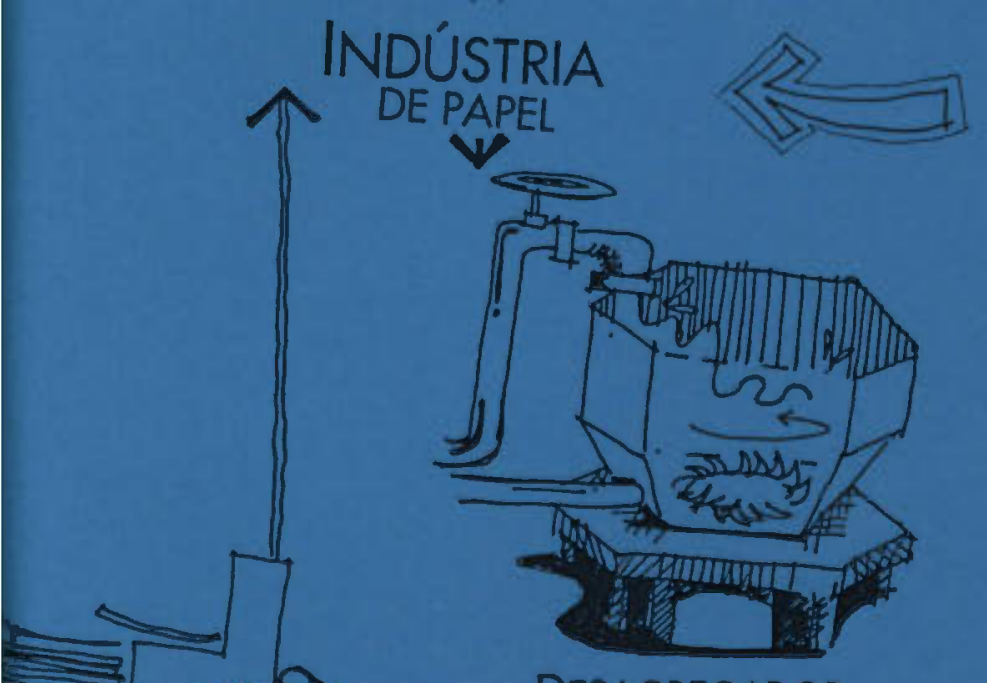

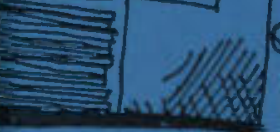

ORTADEIRA

$\uparrow$

ENROLADEIRA

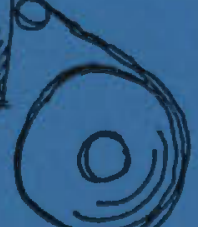

DESAGREGADOR
COLETA

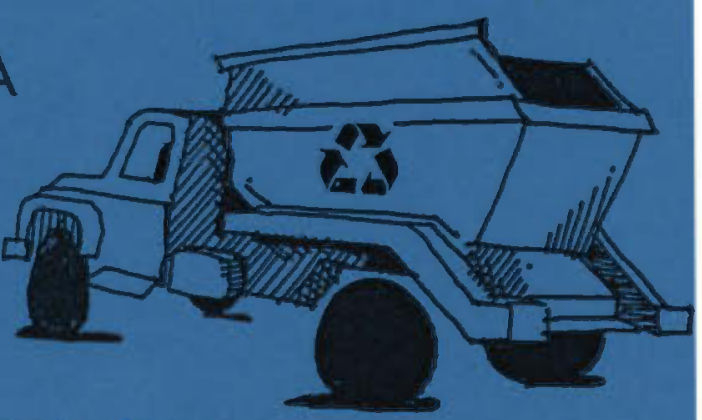

TRANSPORTE
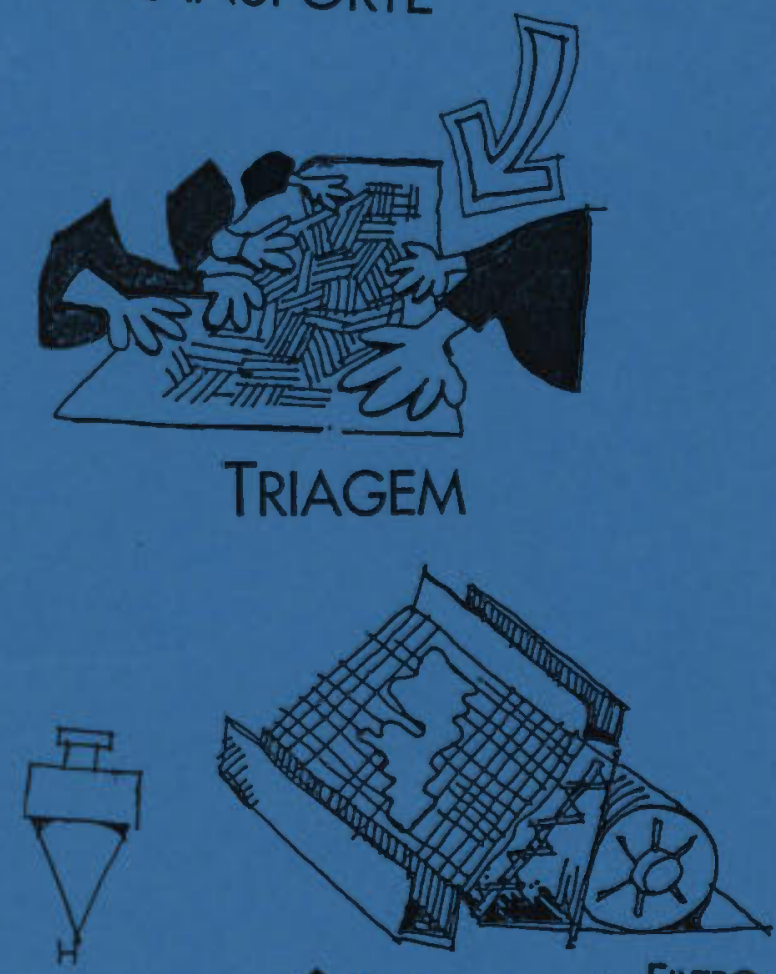

LAVAGEM $\Rightarrow$ Branqueamento $\Rightarrow$ Peneira $\Rightarrow$

DESAGUAD

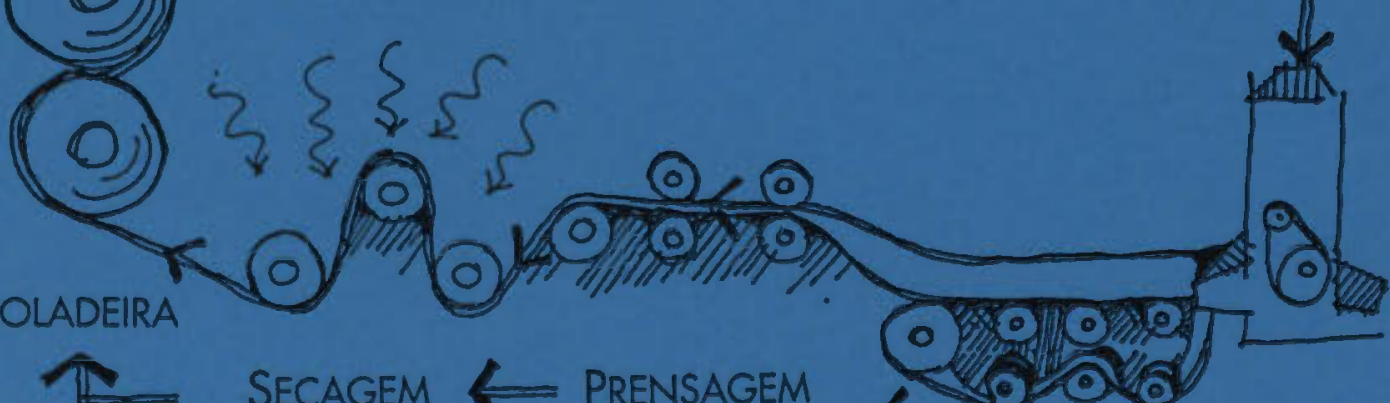

2 SECAGEM $\longleftarrow$ PRENSAGEM 
e onxofre, anteriormente pendurados às cadeias de carbono. $\mathrm{Na}$ decomposição anaeróbia, sem oxigênio e menos eficiente. os restos são mais complexos, como o gás metano e sulfídrico.

Esse trabalho pode demorar um século ou mais (veja ilustraçōes). O tempo depende de vários fatores. $O$ calor $e$ a umidade do solo. por exemplo, estimulam o crescimento e a atividade dos microorganismos acróbios. Assim. quanto mais quente émido for o local. mais rápida será a decomposição. Por outro lado, as águas e terrenos ácidos limitam a capacidade de desenvolvimento dos microorganismos. Os ácidos, metais pesados e substâncias tóxicas prejudicam as bactérias, podendo chegar a matá-las.

Outro problema: a gastronomia dos microorganismos. Certas colônias de bactérias de um determinado terreno nảo são capazes de decompor resíduos - facilmente devorados por outro tipo de micróbio. Por exemplo, se o ierreno nåo dispuser de uma quantidade razoável de oxigênio. diversas substâncias, como o azeite e alguns pesticidas. nāo sofrem degradação. É difícil determinar as preferências e localizações das

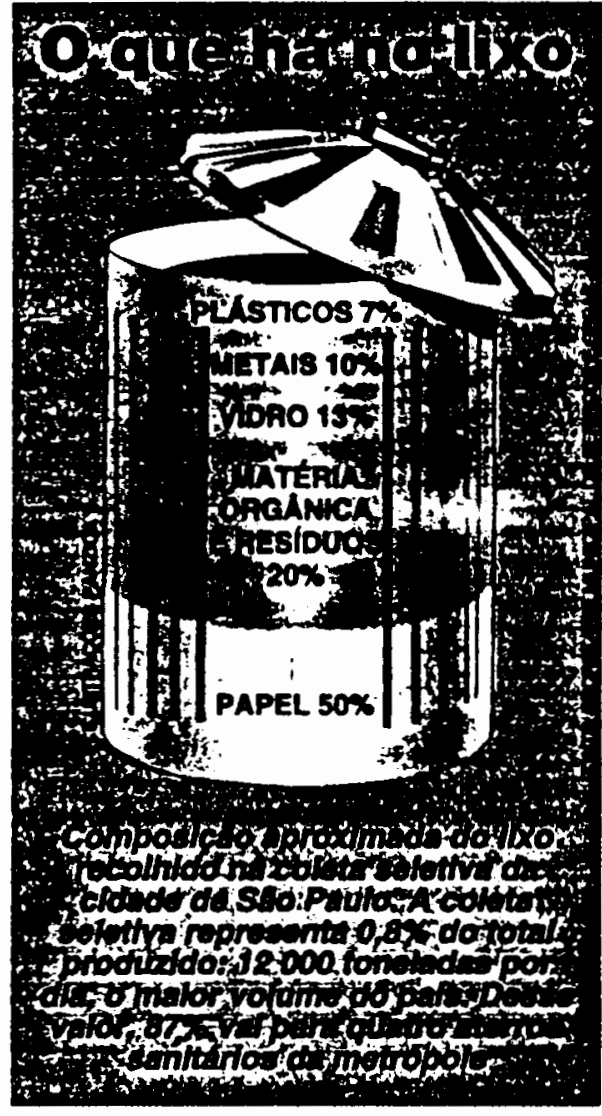

incontáveis espécies de bactérias. As mais conhecidas são as anaeróbias e entre estas as mais comuns pertencem a um grande grupo chamado de metanogênico, pois produzem metano.

Em vista de tudo isso, é claro que sempre vale a pena procurar uma lata de lixo - e mesmo assim persiste o risco de o planeta se converter num autêntico lixão. Basta ver os dados do Plano Nacional de Limpeza Urbana (Planurb), do Ministério da Ação Social. Ai se estima que o Brasil produz uma montanha de mais de 80000 toneladas de lixo por dia, das quais só a metade é coletada. Da parte que é coletada, o Planurb indica que $34 \%$ vai para lixões a céu aberto e $63 \%$ termina em beiras de rios e áreas alagáveis. Não admira que $65 \%$ das internaçōes hospitalares no Brasil decorram de doenças transmissíveis pela água. Cada cidade tem seu sistema de reciclagem, que reduz os resíduos e lamberm economiza recursos, pois aquilo que se recupera do lixo volta à fábrica como matéria-prima. É uma pena que. em São Paulo. das 12000 toneladas diárias de lixo, apenas $0,8 \%$ sejam recicladas.

\section{ependerá do tipo de fixo

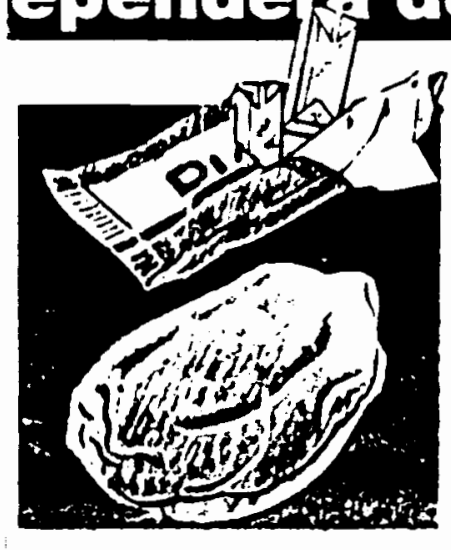

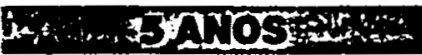 \\ Um chiclete jogado no chāo começa a ser destruído pela luz e pelo oxigênio do ar, que o fazem perder $a$ \\ elasticidade $e$ a viscosidade. Como a goma contém resinas naturais e artificiais, além de açucar e outros ingredientes, o processo pode durar até 5 anos. A pulverização do chiclete é mais rápida se ele gruda no sapato de algum distraído.

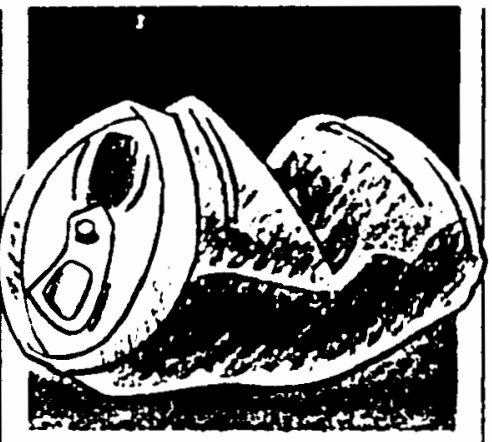

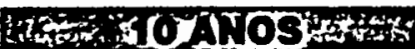 \\ Os metais, em principio, não são biodegradáveis. Uma lata de aço se desintegra em uns 10 anos, convertendo-se em óxido de ferro. Em dois verōes chuvosos, 0 oxigénio da água começa a oxidar as latas feitas de aço recoberto de estanho e verniz. Já uma lata de alumínio não se corrói nunca. E boa parte dos refrigerantes é vendida em latas de aluminio.
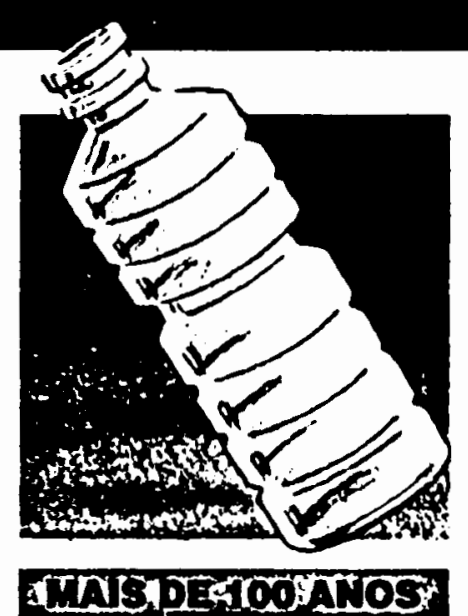 \\ As boas qualidades do plástico - sua durabilidade e resistência à umidade e aos produtos quimicos - impedem sua decomposição. Como este material existe há apenas 1 século, não é possivel determinar seu grau de biodegradação, mas estima-se que uma garrafa de plástico demoraria centenas de anos para desaparecer.

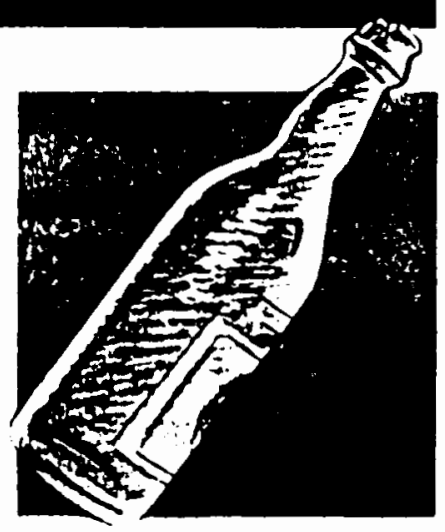

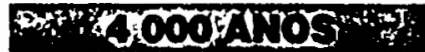 \\ $O$ vidro não se biodegradará jamais. Sua resistência é tamanha que arqueólogos encontraram utensílios de vidro do ano de 2000 a.C. Por ser composto de areia. sódio, cal $\theta$ vários aditivos, os microorganismos não conseguem comê-lo. IJm iecipiente de vidro demoraria 4000 anos para se desintegrar pela erosão e ação de agentes quimicos.}




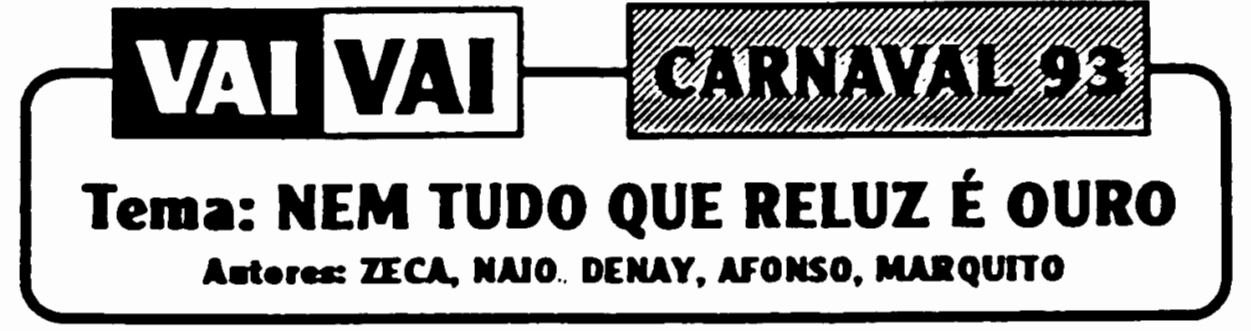

Em nome da ganáncia e da riqueza

Da luxuria e da beleza

O ouro reluziu

E sorriu da nossa agonia

Virou rel se fez mania

O mundo consagrou, ó ó ó

Brindou com mil histórias

Heróis, Mitos e Reis

Hoje seu brilho é lel, é poder

Superando nobres ideais

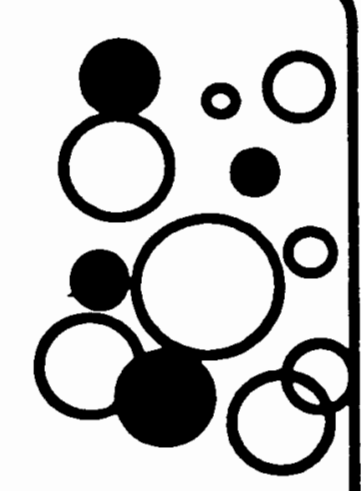

Elaxo, \& Ilxo \& prazer

Oure de tolo, sonhar con dolar Jerre o petóleo

Cartels deftam e rolam

Leva meu samba

Um canto de refiexāo

Que tesouro, é a água, é a terra (é o nosso ar)

Tá na liberdade

$\mathrm{Na}$ felicidade etema

Tá no sangue, vem da alma, do amor

Tá no coração dos homens

Está na paz, está na flor

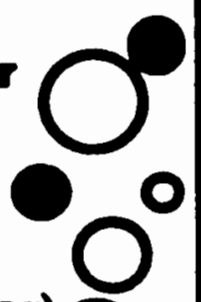

Tem mals valor, um doce beljo, tell $\mathbf{O}$

O Mals emoção o nosso camavil:

- O A Bela Vista vem de novo al

0 Com multo brilho, pra te alucinar 0

Q mell malor tesouro

E ver o povo dellrar

- 0

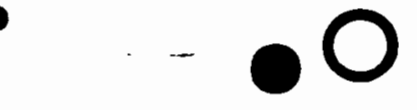

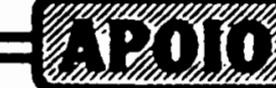



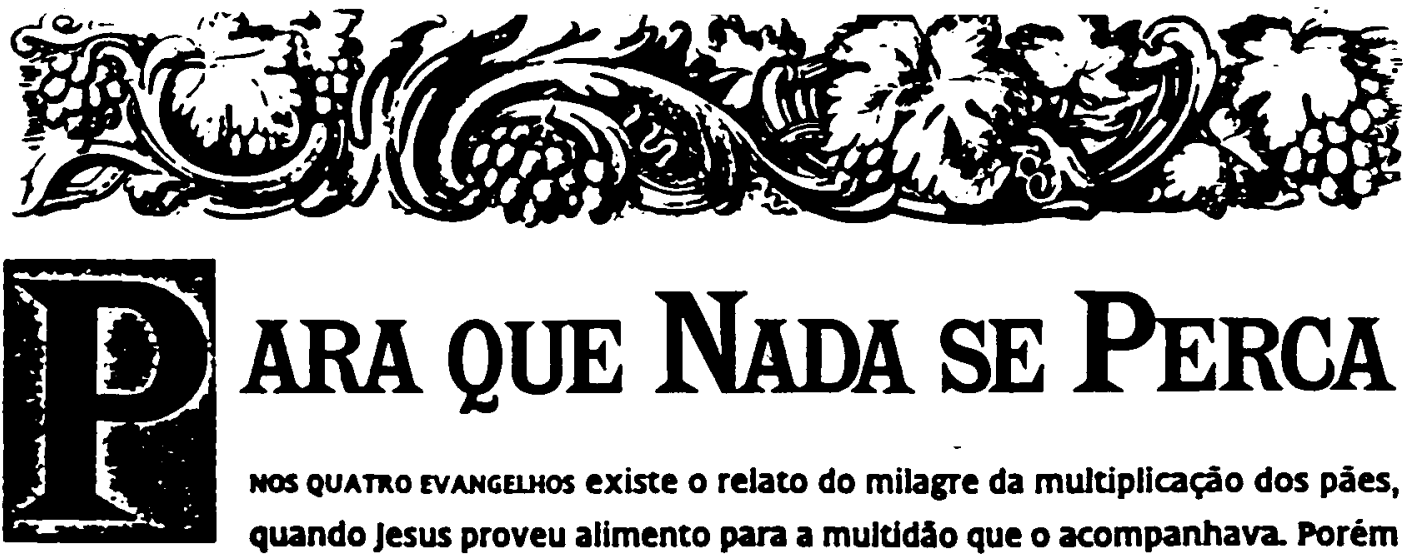

\section{ARA QUE NADA SE PERCa}

mos Quatro evangerhos existe o relato do milagte da multiplicação dos pães, quando jesus proveu alimento para a mulédão que o acompanhava. Porém só João, o mais reflexivo dos narradores, registra uma pouco citada frase do Mestre, dedicada às "sobras" da memorável celebração.

T quando jt estavam fartos, disse jesus a os seus discipulos:

Recollnel o que sobrou para que nada se pere" pode a.12)

E aparentemente enigmática a preocupaço do Mestre com sobras e restos, justamente no momento de tamanho prodigio, que maravilhou os presentes, fazendo-os reconhecer que "ali estava o Profeta que devia vir ao mundo". Afinal, que importancia teriam sobras para quem detinha o dominio sobre os céus e a terra, sobre a vida e a mortel Que releváncia poderiam ter restos diante de tanto poder e glórial

Naverdade, os Evangethossurpreendem os menos atentos. Relacam entre outras colsas a vida do Ftho de Deus, andando, precoupando-se, amando e agindo também entre os doentes, loucos, desentados e humilhados Revelando a povo (e a noss) quaso diferentes podem ser os valores de Deus.

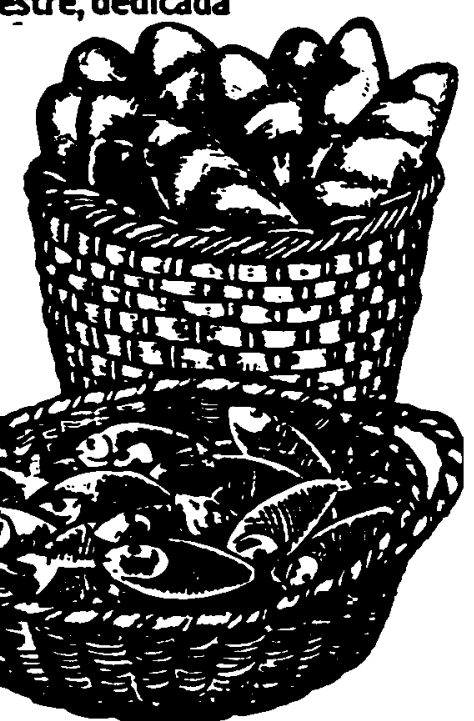

Mas, all em Josio, esth o registro inequivoco de uma preocupaçäo e cuidado com also a que ambém damos pouca atençio, quando não apenas desprezo: o que sobra, os residuos de

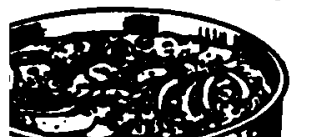
nossas attividades. As palavras do Mestre sto simples e direcas, iguaimente próprias para "sábios" e "Ignorantes". O Mesmo que nos fala da solidariedade, do amor ao próximo e da salvaçao, o Mesmo que nos exorta a náo estarmos ansiosos pela vida, mas ances que nos voltemos para a beleza da criaçao ("Olhai os lírios do campo_-" é Aquele que nos dá uma singela liçăo contra o desperdidio.

No momento em que a discussão sobre o meio ambiente se acirra, quando textos e teses sobre desenvolvimento sustentado e conservaçáo da natureza são produzidos às centenas (indiscriminadamente), quando se exige, para a salvaçăo do Planeta, menos desperdicio, racionalização dos recursos renováveis e najo-renováveis e menor produçáo de lixxo, cabe aos cristáos voltarem-se antes de tudo para os simples e inesgotáveis ensinamentos do Mestre.

Que mudanças prodigiosas teríamos em nossas vidas, em nossas cidades, em nosso Planeta, se passassemos simplesmente a recolher o que sobra, a fim de que nada se perdesse!

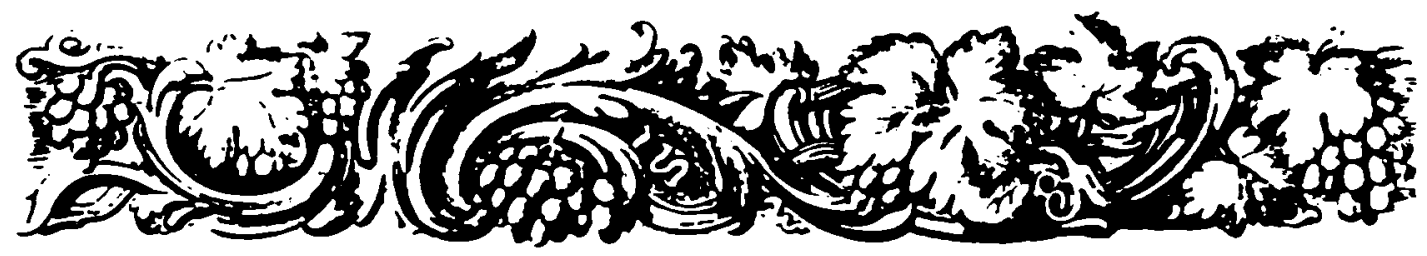

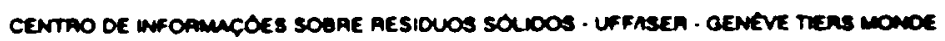

